
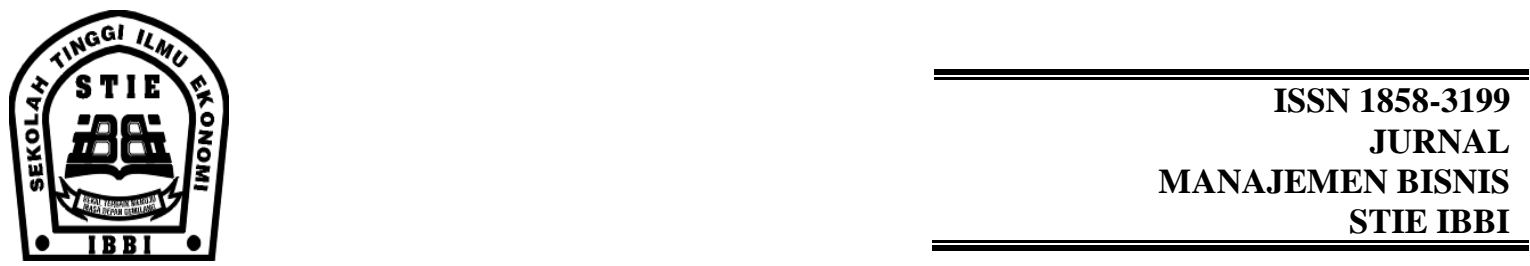

\title{
Pengaruh Kepemilikan Manajerial, Kepemilikan Institusional, Resiko Bisnis, Profitabilitas, Ukuran Perusahaan Terhadap Kebijakan Hutang dan Kebijakan Dividen Serta Pengaruhnya Terhadap Nilai Perusahaan Yang DimoderasiI Oleh Corporate Governance
}

\author{
Hasrul Siregar, SE., M.Si \\ Yusdiana, SE., M.Si \\ Dosen Tetap STIE IBBI Medan
}

\begin{abstract}
ABSTRAK
Tujuan utama perusahaan pada umumnya adalah untuk meningkatkan kemakmuran pemegang saham. Lazimnya kemakmuran pemegang saham digambarkan dengan perolehan gapital gain sebagai dampak peningkatan nilai pasar saham dari waktu ke waktu. Hal tersebut dapat dicapai dengan tata kelola perusahaan yang optimal melalui penerapan good corporate governance. Penerapan good corporate governance dipercaya dapat meningkatkan nilai perusahaan ( value of the firm ).

Beberapa factor yang dapat mempengaruhi peningkatan nilai perusahaan selain corporate governance adalah efisiensi dalam kebijakan hutang dan kebijakan dividend, peningkatan pengawasan melalui kepemilikan saham oleh pihak internal dan pihak ekternal institusi lain. Kebijakan ini juga dipercaya dapat menciptakan suatu mekanisme pengawasan yang lebih ketat sehingga perusahaan dapat mengurangi biaya keagenan yang ditimbulkan oleh sikap opportunistic dari manajer. Kepemilikan oleh pihak insider dan institusi menjadikan manajer bersikap lebih terlibat dan merasa bertanggung jawab terhadap resiko kegagalan.

Penelitian ini bertujuan untuk menganalisis bagaimana variable-variabel tersebut dapat mempengaruhi nilai perusahaan. Hasil penelitian ini nantinya akan bermanfaat kepada internal perusahaan untuk lebih memperhatikan kebijakan-kebijakan yang dibuat terutama kebijakankebijakan menyangkut struktur kepemilikan saham, kebijakan hutang, kebijakan dividend dalam kaitannya meningkatkan nilai perusahaan. Bagi investor, hasil penelitian ini diharapkan dapat memberikan gambaran tentang keberadaan nilai perusahaan yang dikaitkan dengan corporate governance, kebijakan hutang dan kebijakan dividend yang diambil perusahaan, yang diharapkan dapat menjadi tolak ukur nilai saham oleh calon investor. Bagi akademika, penelitian ini diharapkan mampu menambah khasanah ilmu pengetahuan khususnya menyangkut nilai perusahaan, dividend, hutang dan corporate governance. Sedangkan bagi peneliti lain, hasil penelitian ini diharapkan memberikan gambaran ilmiah tentang variable-variabel yang mempengaruhi nilai perusahaan yang dapat menjadi informasi kepada penelitian selanjutnya.

Beberapa hasil penelitian menunjukkan bahwa secara parsial kepemilikan manajerial, resiko bisnis, profitabilitas,ukuran perusahaan signifikan mempengaruhi kebijakan hutang perusahaan. Selain itu penelitian menghasilkan profitabilitas, ukuran perusahaan secara parsial signifikan mempengaruhi kebijakan dividend. Yang terakhir, kebijakan dividen dan penerapan good corporate governance secara parsial signifikan mempengaruhi nilai perusahaan.
\end{abstract}



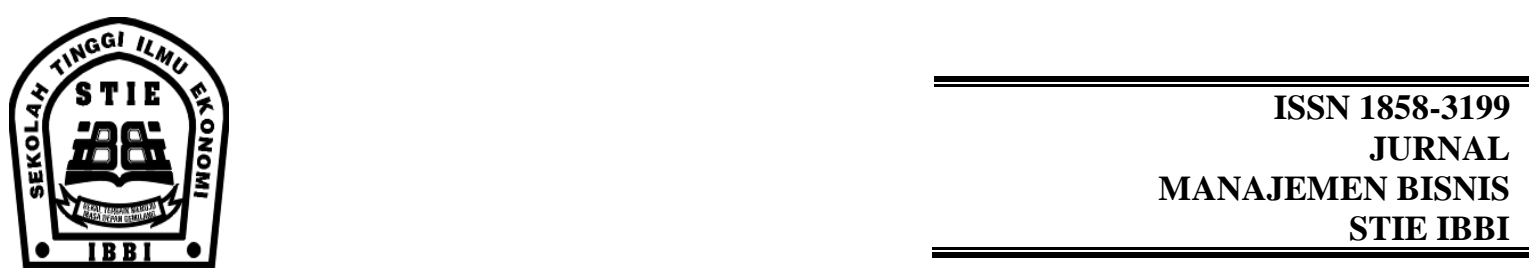

\section{A. Latar Belakang Penelitian}

Tujuan akhir dari perusahaan adalah bagaimana meningkatkan nilai perusahaan melalui kemakmuran bagi pemegang saham. Peningkatan nilai perusahaan tentunya tidak terlepas dari bagaimana perusahaan mengelola perusahaan dengan baik yang ditunjukkan oleh good corporate governance yang maksimal. Corporate government merupakan upaya-upaya yang dilakukan perusahaan untuk mencari cara-cara terbaik dalam mengelola perusahaan. Penerapan corporate governance yang baik dipercaya dapat meningkatkan value of the firm (Siallagan 2006 ).

Untuk mencapai tujuan tersebut lazimnya pemilik modal mempercayakan pengelolaan perusahaan kepada professional manajerial sering disebut agen atau insiders. Agensi atau manajerial akan bertanggung jawab minimal dalam tiga hal. Yang pertama, bagaimana memperoleh sumber dana yang paling optimum. Yang kedua, bagaimana mengalokasikan dana yang berasal dari dalam (internal financing ) maupun dana yang berasal dari luar (external financing) untuk kepentingan bisnis atau investasi mana yang paling menguntungkan. Yang ketiga, menyangkut keputusan dividend.

Pemberian kepercayaan kepada insider ini dipandang sebagai pemisahan atas kekuasaan dalam decision making dan risk beating. Investor atau pemilik menginginkan agar dana yang ditanamkan dalam perusahaan aman, sementara manajer atau insider akan mendapatkan gaji dan fasilitas lainnya atas kepercayaan yang diberikan kepadanya dalam pembuatan keputusankeputusan yang baik. Kenyataan yang sering terjadi, agen atau manajer yang sudah dipercaya oleh pemilik tidak menjalankan fungsinya dalam memaksimumkan nilai perusahaan. Manajer justru berfikir dan bertindak bagaimana memaksimumkan kesejahteraan diri sendiri. Hal ini sering disebut sebagai agency conflict, dimana tindakan-tindakan manajer sering bertentangan dengan keinginan pemilik. Salah satu konflik yang sering terjadi adalah penggunaan sumber dana, dimana pemilik lebih menyukai penggunaan hutang ketimbang equity sedangkan insider menganggap hutang adalah lebih berisiko yang merupakan beban bagi insiders. Manajer karena sangat perkepentingan dalam pencapaian laba dan target pribadi, maka banyak insider yang menanamkan sahamnya diperusahaan yang dikelolanya sendiri, hal ini sering disebut insider ownership ( kepemilikan manajer ). Kepemilikan manajerial ini tentunya akan mempengaruhi keputusan yang akan diambilnya yang akhirnya mempengaruhi nilai perusahaan. Menurut teori keagenan ( Jensen dan Meckling, 1976 ) kehadiran kepemilikan saham oleh manajerial dapat mengurangi conflict karena dengan memiliki saham perusahaan diharapkan manajer merasakan langsung manfaat dari setiap keputusan yang diambilnya, begitu pula bila terjadi kesalahan maka manajer juga akan menanggung kerugian sebagai salah satu konsekuensi dari kepemilikan saham . Proses ini dinamakan bonding mechanism, yaitu proses untuk menyamakan kepentingan manajemen dalam modal perusahaan. Dengan demikian perusahaan akan memiliki agency cost of equity yang kecil karena kepemilikan manajerial ( Megginson, 1997 dalam Soesetio Yuli 2008). Mekanisme pengawasan internal dapat juga dilakukan dengan kepemilikan saham oleh institusional seperti perusahaan, bank, ataupun perusahaan asuransi. Wahidahwati (2001), Listyani (2003), Zulhawati dalam Rizka (2009) dan Masdupi (2005) konsisten menemukan bahwa kehadiran kepemilikan institusional dapat mengurangi hutang dalam hal ini berupa agency cost debt dalam rangka efisiensi perusahaan. Dengan demikian, adalah sesuatu yang relevan jika mengkaitkan struktur kepemilikan dalam hal ini kepemilikan manajerial dan kepemilikan institusional terhadap kebijakan hutang dan nilai perusahaan. 


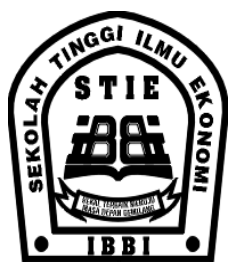

ISSN 1858-3199

JURNAL

MANAJEMEN BISNIS

STIE IBBI

Salah satu kebijakan yang dapat mempengaruhi nilai perusahaan adalah kebijakan hutang. Salah satu hasil penelitian Taswan (2008) menyimpulkan bahwa kebijakan hutang berpengaruh signifikan posititif terhadap nilai perusahaan. Perusahaan tentunya tidak akan terlepas dari bagaimana mengelola hutang. Sejalan dengan berkembangnya investasi dalam negeri, maka perusahaan dituntut untuk menyediakan dana yang lebih besar. Pemenuhan dana dari internal financing jelas tidak mencukupi sehingga perusahaan harus mencari dari sumber external financing. Secara garis besar financing dapat dilakukan dengan menambah equity atau menambah debt. Menambah equity identik dengan menambah jumlah pengendali dalam perusahaan. Sebaliknya menambah debt akan menimbulkan konflik keagenan ( agency conflict) antara owner dengan agen ( manajer ). Kebijakan hutang juga akan berhubungan dengan nilai perusahaan. Taswan (2008) menyatakan bahwa dengan mempertimbangkan pajak, struktur modal menentukan value of the firm. Semakin tinggi proporsi hutang maka semakin tinggi harga saham, namun pada titik tertentu peningkatan hutang akan menurunkan nilai perusahaan karena manfaat yang diperoleh dari penggunaan hutang lebih kecil daripada biaya yang ditimbulkannya. Sedangkan Homaifar, Benkato dan Zietz (1994) menemukan bahwa keuntungan saham mempengaruhi keputusan struktur modal. Mereka menemukan hubungan negative antara keuntungan saham dengan hutang. Argumen ini mendukung pendapat bahwa perusahaan cenderung menggantikan hutang dengan equity apabila return saham tinggi. Dari pendapat diatas, adalah releven untuk menghubungkan kebijakan hutang dengan nilai perusahaan.

Kebijakan lain yang sangat penting menjadi perhatian perusahaan adalah kebijakan dividend. Kebijakan dividen menyangkut keputusan untuk membagikan laba atau menahannya guna diinvestasikan kembali dalam perusahaan ( Weston dan Brigham, 1994 ). Ada perbedaan pendapat tentang hubungan kebijakan dividend dengan nilai perusahaan. Modigliani Miller berpendapat bahwa kebijakan dividend yang optimal tidak akan meningkatkan nilai perusahaan. Kelompok kedua adalah pendapat Gordon-Lintner yang menyatakan bahwa dividend lebih kecil resikonya daripada capital gain, sehingga dividend setelah pajak akan meminimumkan biaya modal. Kelompok ketiga menyatakan bahwa dividend cenderung dikenakan pajak daripada capital gain. Mereka berpendapat bahwa dividend payout ratio yang lebih rendah akan memaksimumkan nilai perusahaan.

Meningkatnya nilai perusahaan dapat menarik minat para investor ( khususnya capital gain dan dividen ) untuk menanamkan modalnya. Dalam hal ini manajer harus memutuskan apakah laba yang diperoleh perusahaan selama satu periode akan dibagikan seluruhnya atau hanya sebagian yang dibagikan sebagai dividend dan sisanya ditahan perusahaan (retained earning ). Menurut Rozeff (1982) dan Easterbrook (1984) bahwa dividend dapat digunakan untuk mengurangi equity agency cost yang timbul dari adanya perbedaan kepentingan dalam perusahaan. Tidak jarang pihak manajemen perusahaan mempunyai tujuan lain yang bertentangan dengan tujuan utama perusahaan ( agency conflict). Manajer atau insiders sering mengutamakan kepentingan pribadi yang menimbulkan biaya sehingga mengurangi keuntungan perusahaan dan dividend yang akan diterima pemegang saham. Kerugian ini merupakan agency cost equity bagi perusahaan ( Jensen dan Meckling, 1976 ). Penjelasan diatas secara garis besar menyatakan bahwa menghubungkan kebijakan divend dengan nilai perusahaan adalah menjadi relevan.

Banyak factor-faktor yang akan mempengaruhi kebijakan hutang di sebuah perusahaan. Salah satu yang mempengaruhi kebijakan hutang adalah profitabilitas yang merefleksikan laba untuk penanaman investasi. Berdasarkan pecking order theory, laba ditahan (retained earning ) adalah merupakan pilihan utama untuk pendanaan, pilihan berikutnya hutang atau equity. Semakin besar keuntungan yang diperoleh maka semakin kecil kemungkinan perusahaan menggunakan hutang 


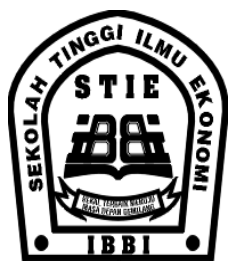

ISSN 1858-3199

JURNAL

MANAJEMEN BISNIS

STIE IBBI

karena dapat menggunakan dari internal equity yang berasal dari laba ditahan ( retained earning ). Faktor lainnya adalah pertumbuhan perusahaan, dimana perusahaan yang masih dalam pertumbuhan sangat membutuhkan dana untuk investasi. Pertumbuhan perusahaan yang besar mempunyai pengaruh positif terhadap hutang perusahaan, karena semakin banyak investasi akan membutuhkan external financing berupa hutang (debt). Pertimbangan lain yang perlu dianalisis adalah resiko bisnis yang merupakan penyimpangan return selama umur investasi. Bethala et al (1994) menggunakan earning volatility sebagai proxy resiko bisnis. Semakin besar penyimpangan yang diukur dengan melihat standar deviasi earning before tax menggambarkan semakin besar resiko bisnis. Perusahaan yang memiliki resiko bisnis yang lebih tinggi cenderung memiliki rasio hutang yang lebih rendah ( Bethala et al 1994) yang menunjukkan keengganan manajemen perusahaan untuk menambah hutang.

Kebijakan dividend juga dipengaruhi oleh beberapa factor, diantaranya struktur modal yang menggambarkan kepemilikan manajerial dan kepemilikan institusional, profitability, likuiditas dan ukuran perusahaan.

Penelitian ini merupakan pengembangan dan sedikit perubahan konstuksi paradigma dari penelitian yang dilakukan oleh Taswan (2003 ), Harahap ( 2010 ) dan Sukirini (2012 ). Jika dibandingkan dengan penelitian yang dilakukan Taswan maka penelitian ini memasukkan variable corporate governance sebagai variable intervening yang mempengaruhi nilai perusahaan. Penelitian Ludwina Harahap lebih focus kepada family ownership dan masalah keagenan dan juga berasumsi bahwa variable growth juga merupakan variable moderating, sementara penulis berasumsi bahwa variable growth merupakan variable eksogen yang mempengaruhi dividend. Dalam penelitian Sukirini variable kepemilikan manajerial, kepemilikan institusional sejajar dengan kebijakan hutang dan kebijakan dividen tanpa ada moderating variable, sementara itu dalam penelitian ini penulis berasumsi bahwa kebijakan hutang dan kebijakan dividend sama-sama dipengaruhi oleh variable kepemilikan manajerial dan kepemilikan institusional dan ada intervenig variable yaitu corporate governance.

\section{B. Perumusan Masalah}

Dari latar belakang yang disampaikan penulis menetapkan rumusan masalah sebagai berikut : " Bagaimana pengaruh variable-variabel kepemilikan manajerial, kepemilikan institusional, resiko bisnis, pertumbuhan, profitability, likuditas dan ukuran perusahaan terhadap kebijakan hutang dan kebijakan dividend serta bagimana pengaruhnya terhadap nilai perusahaan dimana corporate governance sebagai variable intervening. "

\section{Penelitian Terdahulu}

Jensen, et al (1992) meneliti variable-variabel insider ownership, debt dan dividend yang menyatakan bahwa insider ownership mempunyai hubungan negative dengan tingkat hutang dan dividend. Ross (1977) dan Easterbook (1984) menyatakan dalam kesimpulan penelitiannya bahwa untuk mengurangi biaya keagenan diperlukan pembayaran dividen. Pembayaran dividend akan berpengaruh terhadap kebijakan corporate funding, sebab pembayaran dividend akan mengurangi arus kas sehingga perusahaan dalam memenuhi kebutuhan dana operasionalnya harus mencari alternative sumber pendanaan yang relevan. Penelitian tersebut mengindikasikan bahwa adanya simultanitas antara insider ownership, debt dan dividen. Insider ownership berpengaruh terhadap kebijakan dividend dan hutang. Kim dan Sorenson (1986) dengan teori demand and supply hyphotesis, dari sisi demand menjelaskan bahwa perusahaan-perusahaan yang dikendalikan secara 


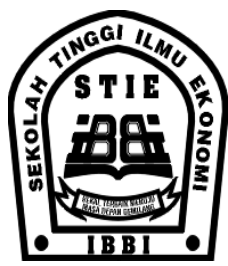

ISSN 1858-3199

JURNAL

MANAJEMEN BISNIS

STIE IBBI

tertutup membutuhkan jumlah pinjaman hutang yang lebih besar karena insider dapat bekerja dengan control secara efektif jika kepemilikan mereka tidak diganti dengan equity. Dari sudut supply, mereka berpendapat bahwa perusahaan-perusahaan yang dikendalikan oleh insider cenderung membutuhkan agency cost of debt yang lebih sedikit, sehingga dapat memperbesar kesediaan hutang ( avaibility pendanaan hutang menjadi lebih tinggi ).

Taswan (2003) dalam judul thesisnya " analisis pengaruh insider ownership, kebijakan hutang dan kebijakan dividend terhadap nilai perusahaan serta factor-faktor yang mempengaruhinya" menyimpulkan beberapa kesimpulan antara lain hutang, internal ownership positif signifikan mempengaruhi nilai perusahaan. Dividend signifikan negative mempengaruhi nilai perusahaan. Resiko bisnis, ukuran perusahaan, internal ownership signifikan mempengaruhi dividend. Pertumbuhan perusahaan, resiko bisnis berpengaruh signifikan positif terhadap hutang tetapi keuntungan berhubungan negative signifikan terhadap hutang. Permodelan yang dilakukan dalam penelitian ini dilakukan dengan linear structural relations ( LISREL ) yang dibangun dalam SEM. Populasi dalam penelitian ini seluruh perusahaan yang listed sejak 1992 sampai dengan 1996. Sedangkan sampel dengan menggunakan purposive sampling dengan tipe judgment sampling.

Sukirni, Dwi (2012), dalam penelitiannya yang berjudul “ Kepemilikan manajerial, kepemilikan institusional, kebijakan dividen, dan kebijakan hutang terhadap nilai perusahaan “ menyimpulkan bahwa kepemilikan institusional dan DER berpengaruh positif signifikan terhadap nilai perusahaan. Populasi dalam penelitian ini adalah perusahaan go public di BEI periode tahun 2008 sampai dengan 2010.

\section{D.Tinjauan Pustaka}

\section{Kepemilikan Manajerial}

Membicarakan struktur kepemilikan bukan hanya membicarakan hutang dan equity dalam pembentukan struktur modal. Menurut Jensen dan Meckling (1976 ) struktur modal juga ditentukan oleh seberapa besar persentase kepemilikan oleh manager dan kepemilikan institusional. Masih menurut Jensen dan Mecking dalam teori keagenan menjelaskan bahwa kepentingan manajemen dan kepentingan pemegang saham seringkali bertentangan, sehingga terjadi konflik diantara keduanya. Kecenderungan yang terjadi manajer lebih mengutamakan kepentingan pribadi. Pemegang saham tidak menyukai kepentingan pribadi manajer sebab akan menambah biaya bagi perusahaan yang akan menurunkan keuntungan yang diterima.

Konflik antara principal ( pemilik ) dan agen ( manajer ) dapat dikurangi dengan mensejajarkan kepentingan antara principal dan agen. Kehadiran manajer dalam kepemilikan saham dapat digunakan untuk mengurangi agency cost karena dengan memiliki saham perusahaan diharapkan manajer merasakan langsung manfaat dari setiap keputusan yang diambilnya, begitu pula bila terjadi kesalahan maka manajer juga akan menanggung kerugian sebagai salah satu konsekuensi dari kepemilikan saham. Proses ini dinamakan bonding mechanism, yaitu proses untuk menyamakan kepentingan manajemen melalui program mengikat manajemen dalam modal perusahaan. Dengan demikian perusahaan akan memiliki agency cost of equity yang kecil karena kepemilikan tadi. ( Megginson,1977 dalam Soesetio Yuli ).

\section{Kepemilikan Institusional}

Kepemilikan institusional berarti saham perusahaan juga dimiliki oleh perusahaan atau institusi lain. Kepemilikan institusional ini juga merupakan upaya pengawasan terhadap kebijakan manajer. Wahidahwati (2002), Listyani (2003), Zulhawati (2004), Masdupi ( 2005 ) menemukan 

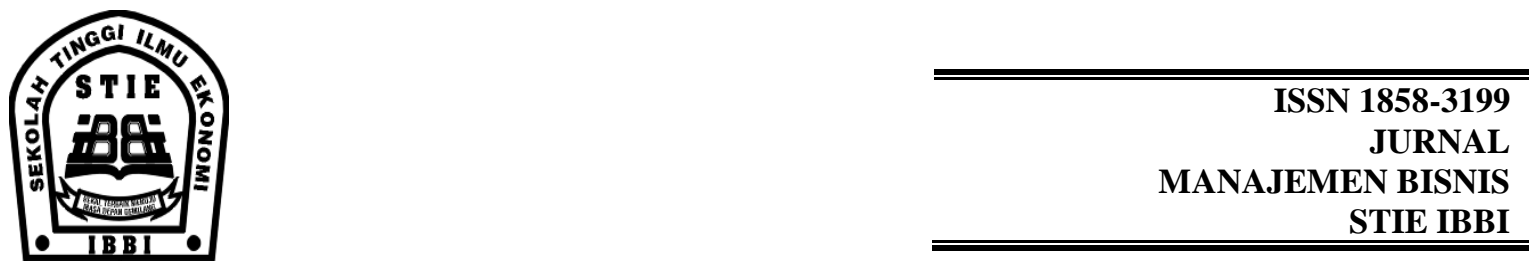

bahwa kehadiran kepemilikan institusional dapat mengurangi hutang perusahaan dalam rangka meminimalkan agency cost of debt. Bentuk kepemilikan institusional berbentuk blocholder yaitu kepemilikan saham oleh perseorangan dengan nilai diatas $5 \%$ dan perseorangan tersebut tidak masuk dalam jajaran manajemen. Institusi biasanya dapat menguasai mayoritas saham karena memiliki sumber daya yang lebih besar bila dibandingkan dengan pemegang saham lainnya.

Pihak institusional diharapkan mampu melakukan pengawasan lebih baik terhadap kebijakan manajer. Kepemilikan institusional dapat melakukan pengawasan yang lebih baik, karena segi skala ekonomi, pihak institusional memiliki keuntungan lebih untuk memperoleh informasi dan menganalisis segala hal yang berkaitan dengan kebijakan manajer. Selain itu, pihak institusional lebih mementingkan adanya stabilitas pendapatan atau keuntungan jangka panjang, sehingga asset penting perusahaan akan mendapatkan pengawasan yang lebih baik ( Han dkk, dalam Soesitio, Yuli 2008 ).

\section{Kebijakan Hutang}

Membicarakan kebijakan hutang sebenarnya adalah membicarakan perimbangan dalam strukur modal. Menurut Riyanto (2001) struktur modal adalah perimbangan atau perbandingan hutang dengan modal sendiri. Keputusan struktur modal berkaitan dengan pemilihan sumber dana baik yang berasal dari dalam maupun dari luar. Sumber pendanaan dari suatu perusahaan dibagi menjadi dua kategori, yaitu pendanaan internal dan pendanaan ekternal. Pendanaan internal dapat diperoleh dari sumber laba ditahan dan depresiasi. Sedangkan pendanaan eksternal dapat diperoleh dari kreditor atau sering disebut hutang. Bisa juga dari peserta atau pengambil bagian dalam perusahaan atau yang disebut sebagai modal. Proporsi atau bauran dari penggunaan modal sendiri dan hutang dalam memenuhi kebutuhan dana perusahaan disebut struktur modal perusahaan.

Salah satu teori yang mendasari keputusan pendanaan perusahaan adalah pecking order theory ( Myers, Najluf 1984) menyatakan bahwa perusahaan melakukan keputusan pendanaan secara hirarki dari pendanaan internal ke eksternal, dari pendanaan yang bersumber dari laba ditahan, hutang sampai pada penerbitan equitas baru. Teori ini menganut keputusan pendanaan dengan urutan preferensi logis investor tehadap prospek perusahaan dan konsisten pada tujuan agar manajer memaksimumkan kemakmuran pemegang saham.

\section{Kebijakan Dividend}

Kebijakan dividend menyangkut keputusan untuk membagikan laba atau menahannya guna diinvestasikan kembali dalam perusahaan. Jika keputusan diambil untuk membagikan laba kepeda pemegang saham, muncul tiga pertimbangan pertimbangan (1) Berapa persentase yang harus dibagikan ? (2) Apakah pembagian itu harus berupa dividen tunai atau dalam bentuk pembelian kembali saham yang mereka tahan ? (3) Bagaimana stabilnya pembagian itu ?; stabil, bervariasi sesuai arus kas, atau bervariasi menurut keinginan perusahaan ? (Brigham dan Houston 2001).

Ketika memutuskan berapa banyak uang kas yang harus dibagikan kepada pemegang saham, manajer keuangan harus mengingat bahwa tujuan perusahaan adalah memaksimalkan nilai pemegang saham. Sehingga, rasio pembayaran yang ditargetkan ( target payout ratio )- yang didefenisikan sebagai persentase dari laba bersih yang harus dibagikan sebagai dividend tunaisebagian besar harus didasarkan pada preferensi investor atas dividen lawan keuntungan modal ; apakah investor lebih suka (1) perusahaan membagikan laba sebagai dividen tunai atau (2) perusahaan membeli kembali saham atau menggunakan kembali laba itu dalam operasi perusahaan, yang keduanya akan menghasilkan keuntungan modal ? Preferensi ini dapat dipertimbangkan dalam pengertian model penilaian saham dengan pertumbuhan konstan : 

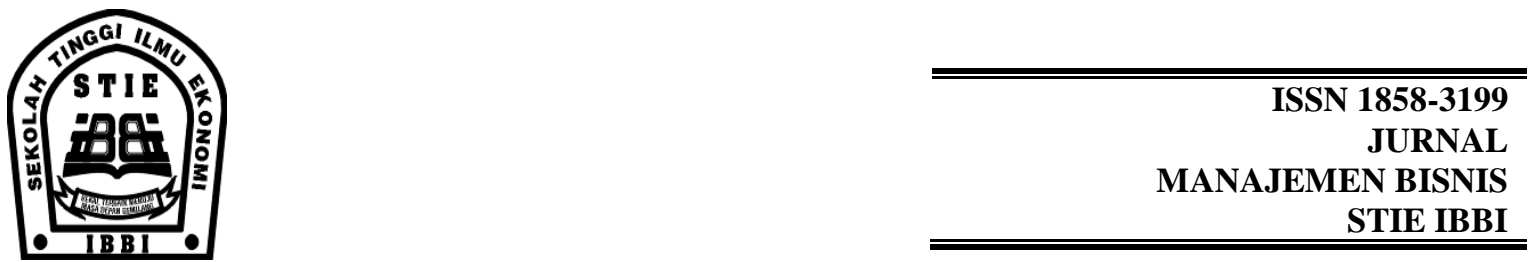

$\mathrm{P}=\mathrm{D} 1 / \mathrm{ks}-\mathrm{g}$

Jika perusahaan menaikkan rasio pembagian, D1 akan naik. Kenaikan dalam pembilang ini saja akan mengakibatkan harga saham naik. Namun, jika dividend tunai meningkat, makin sedikit dana yang tersedia untuk reinvestasi, sehingga tingkat pertumbuhan yang diharapkan akan rendah untuk masa mendatang, dan hal ini akan menekan harga saham. Jadi setiap perubahan dalam kebijakan pembagian akan mempunyai pengaruh yang saling bertentangan. Dengan demikian, kebijakan dividend yang optimal ( optimal dividend policy )perusahaan adalah kebijakan yang menciptakan keseimbangan di antara dividend saat ini dan pertumbuhan di masa mendatang yang memaksimumkan harga saham.

\section{Corporate Governance}

The Indonesian Institute fo Corporate Governance (IICG ) mendefenisikan konsep corporate governance sebagai serangkaian mekanisme untuk mengarahkan dan mengendalikan suatu perusahaan agar operasional perusahaan berjalan sesuai dengan harapan stakeholder. Lebih lanjut IICG mendefenisikan pengertian corporate governance yang baik sebagai struktur, system, dan proses yang digunakan oleh organ-organ perusahaan sebagai upaya untuk memberikan nilai tambah perusahaan secara berkesinambungan dalam jangka panjang ( Igbal Bukhori, Raharja, 2012 ).

Dalam penelitian ini, pengukuran GCG merujuk kepada apa yang dilakukan oleh lembaga survey Indonesia Institute for Corporate Governance ( IICG ). Survei ini telah menghasilkan index yang sering disebut Corporate Governance Perception Index ( GCPI ). Cakupan penilaian meliputi 13 aspek didalamnya termasuk prinsip utama GCG yaitu transparansi, akuntabilitas, responsibilitas, independensi dan keadilan ( fairness ) yang disingkat tariff, ditambah beberapa aspek lain seperti komitmen, kompetensi, kepemimpinan, kemampuan bekerjasama , visi misi, tata nilai, strategi kebijakan, etika dan budaya resiko ( Anissa, Kristina, 2012)

\section{Resiko Bisnis}

Weston (1994 ) mendefenisikan resiko bisnis adalah ketidakpastian dalam proyeksi perusahaan atas tingkat pengembalian atau laba dimasa yang akan datang.

Brigham ( 2001 ) mengidentifikasi resiko menjadi 3 jenis :

1. Resiko stand-alone, adalah resiko proyek dimana proyek ini merupakan satu-satunya aktiva dalam portofolio aktiva perusahaan dan bahwa perusahaan tersebut merupakan satu-satunya saham dalam portofolio saham investor. Resiko stand-alone diukur oleh variabilitas pengembalian yang diharapkan atas proyek.

2. Resiko perusahaan adalah resiko proyek pada perusahaan yang mempertimbangkan fakta bahwa proyek hanya merupakan salah satu dari portofolio aktiva perusahaan, karena itu pengaruh resikonya terhadap profit perusahaan akan terdiversifikasi. Resiko perusahaan diukur oleh dampak proyek terhadap ketidak pastian tentang laba perusahaan di masa depan.

3. Resiko pasar atau resiko beta, adalah resiko proyek yang dinilai oleh pemegang saham yang terdiversifikasi dengan baik, yang mengakui bahwa proyek hanya merupakan salah satu dari aktiva perushaan dan bahwa saham perusahaan adalah sebagian kecil dari portofolio total investor. Resiko pasar diukur oleh pengaruh proyek terhadap koefisien beta perusahaan.

\section{Profitabilitas}

Variabel ini menggambarkan pendapatan untuk membiayai investasi. Profitabilitas menunjukkan kemampuan dari modal yang diinvestasikan dalam keseluruhan aktiva untuk 


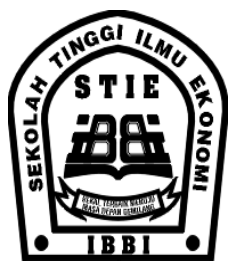

ISSN 1858-3199

JURNAL

MANAJEMEN BISNIS

STIE IBBI

menghasilkan keuntungan bagi investor. Profitabilitas adalah hasil bersih dari serangkaian kebijakan dan keputusan. Brigham (2001) mengukur profitabilitas ini dengan 6 rasio. Yang pertama profit margin on sales, dihitung dengan membagi laba bersih dengan penjualan. Yang kedua, basic earning power, memnujukkan kemampuan aktiva perusahaan untuk menghasilkan laba operasi, dihitung dengan membagi EBIT dengan total aktiva. Yang ketiga, return on asset yaitu mengukur pengembalian atas total aktiva dengan membagi laba bersih untuk pemegang saham biasa dengan total aktiva. Yang keempat, return on equity, yaitu mengukur tingkat pengembalian atas investasi pemegang saham, dilakukan dengan membandingkan laba bersih yang tersedia untuk pemegang saham biasa dengan ekuitas saham biasa. Yang kelima, price earning ratio, yaitu rasio harga persaham terhadap laba per saham, menunjukkan jumlah dollar yang akan dibayar investor untuk setiap \$ 1 laba, diukur dengan membandingkan harga per saham dengan laba per saham. Yang keenam, market book ratio, yaitu rasio harga pasar saham terhadap nilai bukunya, diukur dengan membandingkan harga pasar persaham dengan nilai buku per saham.

\section{Ukuran Perusahaan}

Ukuran perusahaan adalah suatu skala dimana perusahaan dapat diklasifikasikan menurut berbagai cara, antara lain : total aktuva, nilai pasar saham dan laba. Pada dasarnya ukuran perusahaan hanya terbagi dalam 3 kategori, yaitu perusahaan besar (large firm), perusahaan menengah ( medium firm ) dan perusahaan kecil ( small firm ). Penentuan ukuran ini biasaya didasarkan kepada total asset perusahaan.

Perusahaan kecil dan dalam masa pertumbuhan cenderung tidak membayarkan dividennya. Dan perusahaan biasanya baru akan membagikan labanya dalam bentuk dividend setelah perusahaan mencapai titik kedewasaan ( mature) dalam daur hidupnya. Perusahaan kecil dengan kesempatan pertumbuhan yang lebih tinggi lebih memilih seluruh laba bersih operasinya dialokasikan untuk investasi yang profitable, dan tidak menyisakan kas untuk membayar dividen.

Besar kecilnya perusahaan sangat berpengaruh terhadap struktur modal, terutama berkaitan dengan kemampuan memperoleh pinjaman. Perusahaan besar yang telah terdiversifikasi, lebih mudah untuk memasuki pasar modal, menerima penilaian kredit yang lebih tinggi dari bank komersial untuk hutang-hutang yang diterbitkan dan membayar tingkat bunga yang lebih rendah pada hutangnya. Salah satu alasannya perusahaan lebih mudah menerima pinjaman adalah karena nilai aktiva yang dijadikan jaminan lebih besar dan tingkat kepercayaan bank juga lebih tinggi.

\section{E.Kerangka Pemikiran}

Kerangka berfikir merupakan model konseptual tentang bagaimana teori berhubungan dengan berbagai faktor yang telah didefinisikan ( Sekaran dalam Hasan, 2002 ). Dalam kerangka pemikiran perlu dijelaskan secara teoritis hubungan antara variabel independen dan variabel dependen ( Sugiyono, 1999 ). Hasil penelahaan hubungan antara variabel yang diteliti dalam kerangka pemikiran ini akan melahirkan hipotesis-hipotesis.

Kerangka pemikiran dalam penelitian ini merupakan penyatuan dari 3 (tiga) hubungan linieritas, yang pertama (I) : kebijakan hutang perusahaan dipengaruhi oleh kepemilikan manajerial resiko bisnis, profitabilitas, ukuran perusahan, kepemilikan institusional dan kebijakan dividend. Kepemilikan manajerial menggambarkan kepemilikan saham oleh pihak internal manajerial perusahaan. Perusahaan merupakan sumber konflik karena adanya penyebaran keputusan dan resiko. Manajer cenderung menggunakan keuntungan untuk komsumsi oportunistik yang lebih mementingkan keuntungan pribadi. Manajer cenderung mau menerima manfaat penuh 


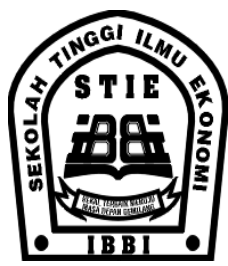

ISSN 1858-3199

JURNAL

MANAJEMEN BISNIS

STIE IBBI

tetapi tidak mau menanggung resiko. Mereka menggunakan hutang yang tinggi bukan untuk maksimalisasi nilai perusahaan tetapi untuk kepentingan opportunistik yang dapat menimbulkan resiko kebangkrutan. Untuk mengurangi resiko ini Jensen dan Mecking (1976) menyarankan untuk meningkatkan kepemilikan saham oleh manajer. Kepemilikan ini akan memaksa manajer terlibat dalam penanggungan resiko jika mereka melakukan kesalahan dalam pengambilan keputusan. Kepemilikan saham oleh manajer akan membuat mereka lebih berhati-hati dalam menciptakan hutang baru sebab hutang cenderung beresiko. Sehingga dapat diasumsikan bahwa kepemilikan manajerial berpengaruh negatif terhadap kebijakan hutang.

Resiko menggambarkan penyimpangan return yang akan diperoleh pada masa yang akan datang. Bathla et al (1994) menggunakan earning volatility sebagai proxy resiko bisnis. Pada perusahaan yang memiliki resiko bisnis yang lebih tinggi akan cenderung memiliki rasio hutang yang lebih rendah. Sehingga dapat diasumsikan bahwa resiko bisnis berhubungan negatif terhadap kebijakan hutang.

Profitabilitas menunjukkan kemampuan modal untuk menghasilkan keuntungan bagi investor pada masa yang akan datang. Menurut Myers dan Majluf (1984) dalam pecking order theory menyatakan bahwa tidak ada suatu target DER tertentu dan tentang hirarki sumber dana yang paling disukai oleh perusahaan. Esensi teori ini adalah adanya 2 jenis modal external financing dan internal financing. Teori ini menjelaskan mengapa perusahaan yang profitable umumnya menggunakan hutang dalam jumlah sedikit. Hal tersebut bukan disebabkan karena perusahaan mempunyai target debt ratio yang rendah, tetapi karena mereka memerlukan eksternal financing yang sedikit. Perusahaan yang kurang profitabel akan cenderung menggunakan utang yang lebih besar karean 2 alasan, yaitu : 1. Dana internal tidak mencukupi dan 2. Utang merupakan sumber eksternal yang lebih disukai. Alhasil, pecking order theory ini membuat hirarki sumber dana yaitu dari internal ( laba ditahan ), dan eksternal ( hutang dan saham ). Pemilihan sumber eksternal menurut Myers dan Majluf (1984) disebabkan karena adanya asimetris informasi antara manajemen dan pemegang saham. Manajer lebih banyak memperoleh informasi daripada pemegang saham. Dari argumentasi diatas, penulis mengambil kesimpulan dari teori ini dan berasumsi bahwa profitabilitas mempunyai hubungan negatif terhadap kebijakan hutang.

Struktur modal sangat dipengaruhui oleh ukuran perusahaan, terutama dalam hal kemampuannya mendapatkan pinjaman. Perusahaan besar, yang sudah mempunyai jumlah asset besar biasanya akan mempunyai akses yang lebih banyak dan yang lebih mudah untuk masuk ke pasar modal. Perusahaan besar juga akan menerima peniliaian kredit yang lebih tinggi dari bank komersial sehingga dimungkinkan akan mendapat pinjaman dalam jumlah yang lebih besar. Dapat diasumsikan bahwa ukuran perusahaan berpengaruh positif terhadap kebijakan hutang perusahaaan. Semakin besar ukuran perusahaan, semakin besar jumlah hutang yang diperoleh perusahaan.

Kepemilikan saham oleh institusional dapat berperan dalam memonitoring manajemen dengan pengawasan yang lebih optimal. Menurut Wahidahwati (2002), Listyani (2003), Zulhawati (2004), Masdupi (2005) menemukan bahwa kehadiran kepemilikan saham oleh institusional dapat mengurangi hutang perusahaan dengan alasan penghematan total biaya keagenan hutang ( agency cost debt ). Berbeda dengan Murni dan Andriana (2007) kepemilikan institusional memiliki pengaruh positif terhadap kebijakan hutang. Mereka berpendapat bahwa kepemilikan institusional memiliki wewenang lebih besar dibandingkan dengan pemegang saham kelompok lain untuk cenderung memilih proyek yang lebih beresiko dengan harapan akan memperoleh keuntungan yang lebih tinggi, sehingga tambahan hutang yang besar adalah sesuatu yang dimaklumi, walaupun dengan pengawasan ketat. Argumentasi diatas lebih berlogika jika menyimpulkan bahwa 


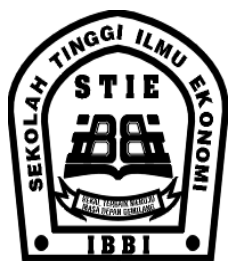

ISSN 1858-3199

JURNAL

MANAJEMEN BISNIS

STIE IBBI

kepemilikan institusional berhubungan positif terhadap kebijakan hutang. Artinya kepemilikan oleh intitusional lebih memperbesar peluang untuk mendapatkan pinjaman hutang dari pihak luar.

Kebijakan dividend memiliki pengaruh terhadap tingkat penggunaan hutang suatu perusahaan. Jensen et al (1992) menyatakan bahwa pembayaran dividen muncul sebagai pengganti hutang dalam struktur modal untuk mengawasi manajer. Dalam hal ini perusahaan yang mempunyai dividend payout ratio tinggi lebih menyukai pendanaan dengan modal sendiri, sehingga dapat mengurangi biaya keagenan jika menggunakan hutang. Pembayaran dividend dapat dilakukan setelah kewajiban bunga dan cicilan terpenuhi. Kewajiban tersebut akan membuat manajer semakin hati-hati dan efisien dalam menggunakan hutang. Moh'd et al (1998) dan Jensen et al (1992) menemukan bahwa dividend payout ratio berpengaruh negatif terhadap debt ratio. Dari argumentasi diatas, dapat diasumsikan bahwa kebijakan dividend berpengaruh negatif terhadap kebijakan hutang .

Hubungan linieritas yang kedua (II) adalah kebijakan dividen dipengaruhi oleh kepemilikan manajerial, resiko bisnis, profitabilitas, ukuran perusahaan, kepemilikan institusional.

Kepemilikan manjerial dalam kaitannya dengan kebijakan hutang dan kebijakan dividend mempunyai peranan penting dalam mengendalikan keuangan perusahaan agar sesuai dengan keinginan pemegang saham. Pengendalian tersebut sering disebut bonding mechanism dimana mekanisme ini berusaha menyamakan kepentingan pemegang saham dengan kepentingan manajemen melalui program-program yang mengikat kekayaan pribadi manajemen ke dalam kekayaan perusahaan. Kepemilikan manajerial, yang dihubungkan dengan kebijakan hutang dan kebijakan dividend akan mengurangi konflik antara pemegang saham dan agen ( Jensen dan Meckling, 1976; Rozeff, 1982; dan Eastbrook, 1984 ). $\quad$ Secara khusus, kepemilikan manajerial berhubungan dengan kebijakan dividend. Semakin besar kepemilikan manajerial cenderung mengurangi dividend pay out. Alasannya adalah bahwa manajer lebih menyenangi menggunakan sumber internal ( laba ditahan ) untuk membiayai investasi pada masa depan artinya lebih suka menahan laba untuk kepentingan investasi daripada menggunakan hutang yang lebih berisiko. Dari penjelasan diatas dapat diasumsikan bahwa kepemilikan manajerial berhubungan negatif dengan kebijakan dividend.

Peningkatan resiko bisnis yang diukur dari peningkatan earning volatility akan meningkatkan biaya kebangkrutan ( debt agency cost) sehingga penurunan jumlah hutang-yang lebih mengandung resiko- akan menjadi solusi untuk mengurangi agency cost tadi. Cara lain untuk mengurangi agency cost adalah peningkatan kepemilikan manajerial dan peningkatan dividend sehingga manajer lebih terlibat dalam resiko pengambilan keputusan. Sehingga dapat dikatakan bahwa jika resiko bisnis meningkat mengindikasikan bahwa perusahaan juga harus menaikkan dividend sebagai upaya menurunkan agency cost.

Profitabilitas merupakan keuntungan bersih yang diperoleh pada periode tertentu. Dalam konteks manajemen keuangan, dividend yang diperoleh adalah merupakan laba bersih yang diperoleh perusahaan, oleh karena itu dividend akan dibagikan apabila perusahaan memperoleh keuntungan. Keuntungan yang dibagikan adalah keuntungan setelah bunga dan pajak. Semakin besar keuntungan berarti semakin besar potensi dividend yang dibagikan.

Perusahaan besar cenderung memiliki akses yang lebih besar kepada sumber dana seperti pasar modal ataupun perbankan, sehingga dimungkinkan untuk mendapatkan dana yang lebih besar dalam aktivitas bisnis dalam rangka memperoleh keuntungan yang lebih besar. Keuntungan yang lebih besar mengindikasikan bahwa dividen yang dibagi juga akan meningkat. Jadi dapat dikatakan bahwa semakin besar ukuran perusahaan semakin besar dividend yang akan dibagikan. 


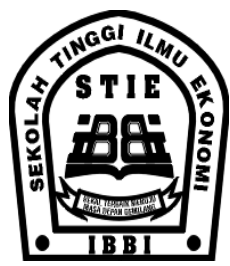

ISSN 1858-3199

JURNAL

MANAJEMEN BISNIS

STIE IBBI

Kepemilikan saham oleh pihak institusional dapat dianggap sebagai mekanisme pengawasan ( bonding mechanism ) yang lebih optimal. Kehadiran kepemilikan saham oleh institusional cenderung mengurangi penggunaan hutang yang lebih beresiko. Intitusional lebih menyukai penggunaan sumber internal seperti laba ditahan untuk pembiayaan investasi. Jadi dapat dikatakan bahwa jika semakin besar jumlah kepemilikan institusional maka semakin kecil dividend yang dibagikan sebagai upaya pengurangan penggunaan hutang dalam pembiayaan investasi.

Hubungan linieritas yang ketiga (III) : Nilai perusahaan dipengaruhi oleh kepemilikan manajerial, kepemilikan institusional, kebijakan hutang kebijakan dividend yang diintervening oleh variabel corporate governance. Para manajer cenderung menggunakan kelebihan keuntungan untuk konsumsi dan cenderung opportunistik. Mereka juga sering menggunakan hutang bukan untuk memaksimumkan nilai perusahaan melainkan untuk kepentingan pribadi . Hal ini dapat menimbulkan meningkatnya cost of debt yang akan menurunkan nilai perusahaan. Salah satu cara untuk mengurangi cost of debt ini adalah dengan penyertaan kepemilikan saham oleh internal manajerial, sehingga manajer menjadi lebih terlibat dalam segala keputusan yang diambilnya. Manajer akan menjadi merasa lebih bertanggung jawab dalam pengggunakan hutang dan keputusan-keputusan lainnya. Sikap kehati-hatian ini akan berdampak pada penurunan cost of debt dan pada akhirnya berpengaruh pada nilai perusahaan. Dapat dikatakan bahwa peningkatan kepemilikan oleh manajerial akan meningkatkan nilai perusahaan.

Sama halnya dengan kepemilikan institusional dimana kepemilikan oleh institusi akan menjadi semacam mekanisme pengawasan yang akan meningkatkan nilai perusahaan. Semakin besar saham dimiliki oleh institusional semakin tinggi nilai perusahaan.

Kebijakan dividend merupakan kebijakan yang sangat penting dalam mempengaruhi nilai perusahaan. Jika dividend lebih besar dikeluarkan mengindikasikan bahwa perusahaan dalam keadaan menguntungkan biasanya diikuti dengan meningkatnya harga saham. Menurut Crutchley dan Hansen (1989) mengatakan bahwa peningkatan dividend diharapkan dapat mengurangi biaya keagenan karena pembayaran dividend yang besar menyebabkan laba ditahan semakin kecil sehingga perusahaan membutuhkan dana tambahan eksternal misalnya penerbitan saham. Penerbitan saham baru akan meningkatkan pengawasan oleh investor. Dari argumen diatas dapat diduga bahwa kebijakan dividend berpengaruh positif terhadap nilai perusahaan.

Jensen(1986) menyatakan bahwa penggunaan hutang dapat mengendalikan penggunaan free cash flow secara berlebihan dengan demikian menghindari investasi sia-sia. Penggunaan hutang juga mengakibatkan manajemen lebih berhati-hati karena hutang dapat menyebabkan peningkatan resiko kebangkrutan. Dari argumen diatas dapat dikatakan bahwa penggunaan hutang yang disertai dengan prinsip kehati-hatian akan meningkatkan nilai perusahaan.

Manajer sering berperilaku opportunistik dalam pengambilan keputusan kebijakan hutang ataupun dividend sehingga muncul konflik keagenan dengan meningkatnya agency cost. Penerapan good corporate governance dalam kebijakan hutang dan kebijakan dividend dipercaya dapat menurunkan agency cost. Manajer akan memfokuskan aktivitasnya untuk peningkatan nilai perusahaan. Dari argumen diatas dapat disimpulkan bahwa penerapan good corporate governance akan meningkatkan nilai perusahaan.

Dari analisis keterkaitan antar variabel diatas dapat digambarkan paradigma kerangka pemikiran seperti terlihat pada gambar 2.1. dibawah ini. 

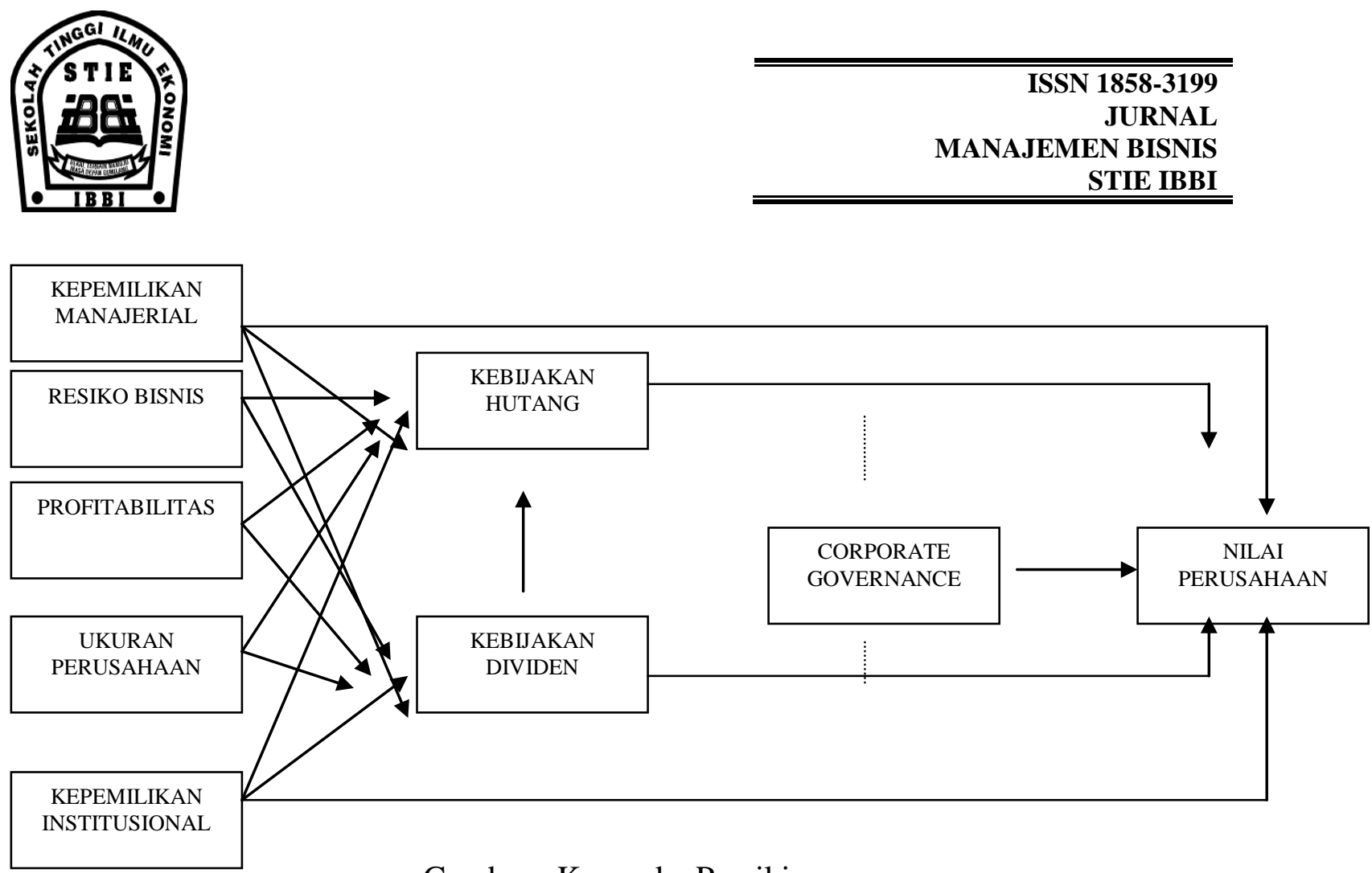

\section{F.Hipotesis}

Gambar : Kerangka Pemikiran

Dari kerangka pemikiran diatas penulis menetapkan hipotesis sebagai berikut :

\section{Model linier I :}

Hipotesis 1 : Kepemilikan manajerial berpengaruh positif terhadap kebijakan hutang.

Hipotesis 2 : Resiko bisnis berpengaruh negative terhadap kebijakan hutang.

Hipotesis 3 : Profitabilitas berpengaruh negative terhadap kebijakan hutang.

Hipotesis 4 : Ukuran perusahaan berpengaruh positif terhadap kebijakan hutang.

Hipotesis 5 : Kepemilikan institusional berpengaruh positif terhadap kebijakan hutang.

Hipotesis 6 : Kebijakan dividend berpengaruh negative terhadap kebijakan hutang.

\section{Model Linier II :}

Hipotesis 7 : Kepemilikan manajerial berpengaruh negative terhadap kebijakan dividend.

Hipotesis 8 : Resiko bisnis berpengaruh positif terhadap kebijakan dividend.

Hipotesis 9 : Profitabilitas berhubungan positif terhadap kebijakan dividend.

Hipotesis 10 : Ukuran perusahaan berhubungan positif terhadap kebijakan dividend.

Hipotesis 11 : Kepemilikan institusional berpengaruh negative terhadap kebijakan dividend.

Model Linier III :

Hipotesis 12: Kepemilikan manajerial berpengaruh positif terhadap nilai perusahaan.

Hipotesis 13: Kepemilikan institusional berpengaruh positif terhadap nilai perusahaan.

Hipotesis 14 : Kebijakan hutang berpengaruh positif terhadap nilai perusahaan.

Hipotesis 15: Kebijakan dividend berpengaruh positif terhadap nilai perusahaan.

Hipotesis 16: Corporate governance berpengaruh positif terhadap nilai perusahaan.

Hipotesis 17: Corporate governance berpengaruh positif terhadap hubungan antara kebijakan hutang terhadap nilai perusahaan.

Hipotesis 18: Corporate governance berpengaruh positif terhadap hubungan antara kebijakan dividend terhadap nilai perusahaan. 


\section{G. Definisi Operasional Variabel :}

Adapun variable-variabel yang akan diteliti ditunjukkan berikut dibawah ini :

Definisi Operasional Variabel

\begin{tabular}{|c|c|c|c|}
\hline Variabel & Defenisi Operasional & Indikator & $\begin{array}{c}\text { Skala } \\
\text { Pengukuran }\end{array}$ \\
\hline $\begin{array}{l}\text { Kepemilikan } \\
\text { Manajerial }\end{array}$ & $\begin{array}{l}\text { Proporsi kepemilikan saham } \\
\text { oleh internal manajemen } \\
\text { perusahaan. }\end{array}$ & $\begin{array}{l}\text { Jumlah saham yang dimiliki oleh } \\
\text { manajer pada akhir tahun periode } \\
\text { tertentu dibagi Total jumlah saham } \\
\text { biasa yang beredar akhir tahun } \\
\text { periode tertentu. }\end{array}$ & Skala Ratio \\
\hline Resiko Bisnis & $\begin{array}{l}\text { Penyimpangan pendapatan } \\
\text { yang terjadi pada periode } \\
\text { umur investasi tertentu. }\end{array}$ & $\begin{array}{l}\text { Deviasi standar Earning Before Tax } \\
\text { dibagi Total Asset }\end{array}$ & Skala Ratio \\
\hline Profitabilitas & $\begin{array}{l}\text { Kemampuan perusahaan untuk } \\
\text { menghasilkan laba pada masa } \\
\text { yang akan datang }\end{array}$ & Operating Income dibagi Total Asset & Skala Ratio \\
\hline Ukuran Perusahaan & $\begin{array}{l}\text { Besar kecilnya } \\
\text { perusahaan yang } \\
\text { dengan total asset yang } \\
\text { dimiliki perusahaan }\end{array}$ & Log Total Asset & Skala Ratio \\
\hline $\begin{array}{l}\text { Kepemilikan } \\
\text { Institusional }\end{array}$ & $\begin{array}{l}\text { Proporsi kepemilikan saham } \\
\text { oleh pihak institusional. }\end{array}$ & $\begin{array}{l}\text { Jumlah saham yang } \\
\text { instusional dimiliki } \\
\text { beredar akhir tahun }\end{array}$ & Skala Ratio \\
\hline Kebijakan Hutang & $\begin{array}{l}\text { Kebijakan penggunaan hutang } \\
\text { oleh perusahaan baik hutang } \\
\text { jangka panjang maupun } \\
\text { jangka pendek }\end{array}$ & Total Hutang dibagi Total Equity & Skala Ratio \\
\hline Kebijakan Dividen & $\begin{array}{l}\text { Kebijakan menyangkut } \\
\text { pemberian bagian keuntungan } \\
\text { kepada pemegang saham }\end{array}$ & $\begin{array}{l}\text { Dividend dibagi Laba Bersih Setelah } \\
\text { Pajak }\end{array}$ & Skala Ratio \\
\hline Corporate Governance & $\begin{array}{l}\text { merupakan suatu cara untuk } \\
\text { menjamin bahwa manajemen } \\
\text { bertindak yang terbaik untuk } \\
\text { kepentingan stakeholders }\end{array}$ & $\begin{array}{l}\text { CGPI ( Corporate Governance } \\
\text { Perception Index ) yang dikeluarkan } \\
\text { oleh The Institute For Corporate } \\
\text { Governance }\end{array}$ & Skala Ratio \\
\hline $\begin{array}{l}\text { Nilai Perusahaan } \\
\text { ( Price Book Value ) }\end{array}$ & $\begin{array}{l}\text { Nilai yang menggambarkan } \\
\text { kemakmuran pemilik atau } \\
\text { pemegang saham. }\end{array}$ & $\begin{array}{l}\text { Market Value of Equity (MVE) dibagi } \\
\text { Book Value of Equity ( BVE ) }\end{array}$ & Skala Ratio \\
\hline
\end{tabular}

\section{H. .Populasi dan Sampel}

Karena penelitian ini berkaitan dengan corporate governance, maka penulis menetapkan populasi dalam penelitian ini adalah perusahaan-perusahaan yang telah ikut serta dalam survey Corporate Governance Perception Index ( GCPI ) tahun 2012 sebanyak 40 perusahaan yang dilakukan oleh The Indonesian Institute for Corporate Governance ( IICG ). Dari 40 perusahaan populasi, selanjutnya diambil 24 perusahaan sebagai sampel yaitu yang ikut survey tetapi sudah terdaftar di Bursa Efek Indonesia. 
I .Model Analisis

Penelitian ini menggunakan model analisis regressi linier berganda dengan 3 model :

Model I $=D E R=\propto+\beta_{2} K M+\beta_{2} R I S K+\beta_{2} P R O F+\beta_{4} S I Z E+\beta_{2} K I+\beta_{2} D P R+\varepsilon$

Model II = DPR $=\propto+\beta_{2} K M+\beta_{2}$ RISK $+\beta_{2} P R O F+\beta_{4} S I Z E+\beta_{2} K I+\varepsilon$

Model III $=P B V=\propto+\beta_{2} K M+\beta_{2} K I+\beta_{2} D E R+\beta_{4} D P R+\beta_{3} C G+\beta_{0} D E R \& C G+\beta_{7} D P R * C G+\varepsilon$

\section{J. Uji Hipotesis Model I}

Tabel 4.5. Hasil Pengujian Model I

\begin{tabular}{|c|c|c|c|c|}
\hline \multirow[t]{2}{*}{ Keterangan } & \multicolumn{2}{|c|}{ Unstandardized Coefficients } & \multirow[t]{2}{*}{ t-hitung } & \multirow[t]{2}{*}{ Signifikansi } \\
\hline & B & Std.Error & & \\
\hline KONSTANTA & $-13,950$ & 5,062 & $-2,756$ & 0,008 \\
\hline MNGR.OWN & 0,130 & 0,271 & 2,479 & 0,033 \\
\hline RISK & $-0,314$ & 0,323 & 2,772 & 0,035 \\
\hline PROF & $-0,221$ & 0,052 & $-4,260$ & 0,000 \\
\hline SIZE & 1,180 & 0,304 & 3,883 & 0,000 \\
\hline INST.OWN & $-1,907$ & 1,287 & $-1,481$ & 0,143 \\
\hline DIVIDEN & $-0,004$ & 0,024 & $-0,171$ & 0,865 \\
\hline $\mathrm{R}$ model & & & 59 & \\
\hline Adj. $R^{2}$ model & & & 34 & \\
\hline F-Hitung & & & & \\
\hline $\begin{array}{l}\text { Signifikansi } \\
\text { Model }\end{array}$ & & & 00 & \\
\hline
\end{tabular}

\section{K. Uji Hipotesis Model II}

Tabel 4.6. Hasil Pengujian Model II

\begin{tabular}{|c|c|c|c|c|}
\hline \multirow[t]{2}{*}{ Keterangan } & \multicolumn{2}{|c|}{ Unstandardized Coefficients } & \multirow[t]{2}{*}{ t-hitung } & \multirow[t]{2}{*}{ Signifikansi } \\
\hline & B & Std.Error & & \\
\hline KONSTANTA & -53.335 & 25,658 & $-2,079$ & 0,042 \\
\hline MNGR.OWN & 1,469 & 1,406 & 1,045 & 0,300 \\
\hline RISK & 2,354 & 1,667 & 1,412 & 0,163 \\
\hline PROF & 0,658 & 0,259 & 2,539 & 0,013 \\
\hline SIZE & 3,747 & 1,522 & 2,462 & 0,016 \\
\hline INST.OWN & 3,878 & 6,719 & 0,577 & 0,566 \\
\hline R model & & & & \\
\hline Adj. $R^{2}$ model & & & & \\
\hline F-Hitung & & & & \\
\hline $\begin{array}{l}\text { Signifikansi } \\
\text { Model }\end{array}$ & & & & \\
\hline
\end{tabular}




\section{L.Uji Hipotesis Model III}

Tabel 4.7. Hasil Pengujian Model III

\begin{tabular}{|c|c|c|c|c|}
\hline \multirow[t]{2}{*}{ Keterangan } & \multicolumn{2}{|c|}{ Unstandardized Coefficients } & \multirow[t]{2}{*}{ t-hitung } & \multirow[t]{2}{*}{ Signifikansi } \\
\hline & B & Std.Error & & \\
\hline KONSTANTA & 4,757 & 14.361 & 0,331 & 0,742 \\
\hline MNGR.OWN & $-0,17$ & 1,206 & $-0,014$ & 0,989 \\
\hline INST.OWN & 0,888 & 5,317 & 0,167 & 0,868 \\
\hline DEBT & 0,023 & 0,444 & 0,051 & 0,959 \\
\hline DIVIDEN & 3,153 & 1,296 & 2,434 & 0,018 \\
\hline GCG & 4,216 & 1,937 & 2,176 & $\mathbf{0 , 0 3 3}$ \\
\hline $\begin{array}{l}\text { MODERAT } \\
\left(\mathrm{DER}^{*} \mathrm{GCG}\right)\end{array}$ & 0,100 & 2,123 & 0,047 & 0,962 \\
\hline $\begin{array}{l}\text { MODERAT2 } \\
(\mathrm{DPR} * \mathrm{GCG})\end{array}$ & $-1,130$ & 1,932 & $-0,585$ & 0,561 \\
\hline $\mathrm{R}$ model & \multicolumn{4}{|c|}{0,446} \\
\hline Adj. $\mathrm{R}^{2}$ model & \multicolumn{4}{|c|}{0,111} \\
\hline F-Hitung & \multicolumn{4}{|c|}{2,268} \\
\hline $\begin{array}{l}\text { Signifikansi } \\
\text { Model }\end{array}$ & \multicolumn{4}{|c|}{0,040} \\
\hline
\end{tabular}

\section{Pembahasan}

Dari model I, secara serempak variabel kepemilikan oleh manajerial, resiko bisnis, tingkat keuntungan, ukuran perusahaan, kepemilikan oleh institusional dan kebijakan dividend signifikan berpengaruh terhadap kebijakan hutang. Hasil ini konsisten dengan penelitian yang dilakukan oleh Taswan (2003) dan Harahap (2010). Secara partial kepemilikan saham oleh manajerial mempengaruhui positip terhadap kebijakan hutang. Semakin banyak porsi kepemilikan saham oleh manajerial semakin besar jumlah hutang yang diciptakan oleh perusahaan. Hal ini disebabkan bahwa dengan keikutsertaan manajer menjadi pemegang saham mekanisme pengawasan internal menjadi lebih baik. Perusahaan yang dijalankan oleh manajerial tersebut tidak ragu untuk memperbesar jumlah hutang ataupun pinjaman dalam rangka meningkatkan investasi perusahaan. Kehadiran manajerial sebagai pemilik dapat mengurangi konflik karena mereka merasakan langsung dari setiap keputusan yang diambilnya. Dengan kata lain bonding mechanism dapat berjalan dengan baik. Hasil ini sejalan teori keagenan ( Jensesn dan Meckling, 1976 ) .

Resiko bisnis juga signifikan berpengaruh negative terhadap kebijakan hutang perusahaan. Semakin besar resiko dari sebuah bisnis - yang diukur dari deviasi dari laba kotor dibagi total assetsemakin kecil nilai hutang perusahaan. Manajemen perusahaan akan mengurangi jumlah hutangnya jika resiko semakin besar. Manajemen berpendapat bahwa menambah hutang akan menambah beban bunga yang identik dengan resiko kebangkrutan.

Dari hasil model I dapat juga kita lihat bahwa semakin kecil ukuran perusahaan semakin besar jumlah hutang yang dimiliki oleh perusahaan. Hal ini berkaitan dengan besarnya jumlah asset. Karena ukuran besar kecilnya perusahaan dikaitkan jumlah asset. Perusahaan kecil cenderung untuk menambah hutangnya demi investasi jangka panjang. Walaupun penambahan hutang seiring dengan menambah resiko karean munculnya bunga. Perusahaan kecil biasanya lebih aggresif untuk 

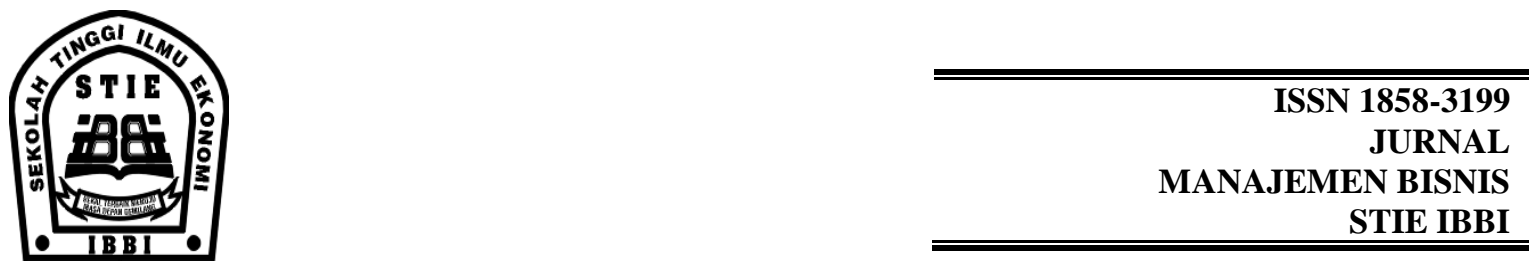

menambah investasi karena keingian menambah tingkat penjualan. Sementara itu, kepemilikan oleh perusahaan dan dividen secara partial tidak signifikan mempengaruhi kebijakan hutang. Dalam kaitan ini, kepemilikan saham oleh perusaahaan tidak dapat dijadikan pengawasan internal. Perusahaan dalam mengelola hutang tidak mempertimbangkan saham yang dimiliki oleh perusahaan lain. Perusahaan tidak menjadikan kepemilikan intitusional sebagai pertimbangan jika perusahaan berkeinginan untuk menambah hutang. Hal ini dapat dimaklumi karena jumlah kepemilikan institusional jumlahnya sangat kecil sehingga tidak dijadikan pertimbangan bagi perusahaan. Sama halnya dengan dividend, juga tidak signifikan mempengaruhi kebijakan hutang. Dalam mengelola hutang perusahaan, perusahaan tidak mempertimbangkan besarnya dividend. Perusahaan lebih mempertimbangkan kepada resiko, tingkat keuntungan dan ukuran perusahaan dalam mengelola hutangnya.

Dari model II, secara serempak kepemilikan manajerial, resiko bisnis, tingkat keuntungan, ukuran perusahaan dan kepemilikan institusional berpengaruh terhadap kebijakan dividend. Jika dikaji secara parsial, hanya tingkat keuntungan dan ukuran perusahaan yang signifikan mempengaruhui kebijakan dividend. Semakin tinggi keuntungan perusahaan semakin besar dividen yang dibagikan. Biasanya dalam sebuah perusahaan laba bersih menjadi pertimbangan utama dalam pembagian dividend. Sama halnya dengan ukuran perusahaan, kecenderungan yang terjadi perusahaan berskala besar akan memberikan porsi dividend yang lebih besar kepada pemegang saham. Hal ini dilakukan untuk lebih merangsang transaksi saham di pasar sekunder dan pandangan positif investor terhadap saham yang dimilikinya. Keadaan demikian dapat mengaibatkan saham lebih diminati yang mengakibatkan harga saham meningkat, gain bertambah dan nilai perusahaan meningkat. Dalam model II ini, kepemilikan oleh manajerial, resiko, dan kepemilikan institusional justru tidak signifikan mempengaruhi kebijakan dividen. Besarnya DPR tidak dipengaruhui oleh kepemilikan manajerial, kepemilikan institusional dan resiko. Kepemilikan baik manajerial maupun institusional secara parsial tidak menjadi pertimbangan dalam pencairan dividen. Yang biasa terjadi, manajer yang memiliki saham akan mengurangi pembagian dividend karena laba ditahan dapat digunakan untuk investasi. Justru dalam temuan penelitian ini tidak demikian. Manajer lebih senang menggunakan sumber eksternal berupa pinjaman dibanding penggunaan sumber internal berupa laba ditahan untuk pengembangan investasi. Hal ini mempunyai alasan, pertama manajer lebih mempertimbangkan pendapatan segera bagi pemegang saham untuk menambah keyakinan kepada pemegang saham lainnya. Dan bisa saja terjadi manajer memutuskan membagi laba karena alasan keuntungan pribadi sesaat, sebab manajer juga adalah pemegang saham. Disinilah letak dilema kepemilikan saham oleh manajerial. Pertimbangan kedua bisa saja bahwa manajer beranggapan menggunakan sumber eksternal hutang sebagai pembiayaan adalah lebih menguntungkan dari segi cost of capital jika suku bunga pada saat itu rendah yang disertai dengan keyakinan bahwa penggunaan hutang akan berhasil jika mampu melakukan pengawasan keuangan yang lebih intensif. Manajer beranggapan lebih wajar jika membagikan dividend lebih besar sebagai konsekuensinya lebih menggunakan external financing berupa penggunaan hutang untuk membiayai investasi. Temuan ini juga menyimpulkan bahwa resiko bisnis tidak signifikan mempengaruhi besarnya dividend yang dibagikan. Perusahaan hanya mempertimbangkan keuntungan dan ukuran perusahaan sebagai indikator pembagian dividen.

Model III mengindikasikan bahwa secara serempak kepemilikan manajerial, kepemilikan institusional, kebijakan hutang, kebijakan dividen, good corporate governance, moderat 1 ( corporate governance yang menjadi variabel moderating antara debt dgn nilai perusahaan ), moderat 2 ( corporate governance yang menjadi variabel moderating antara dividen dgn nilai perusahaan ) signifikan berpengaruh terhadap nilai perusahaan. Hal ini konsisten dengan penelitian yang 


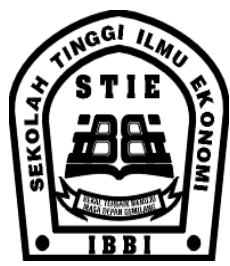

ISSN 1858-3199

JURNAL

MANAJEMEN BISNIS

STIE IBBI

dilakukan oleh Sukirni, Dwi (2012). Namun secara parsial hanya kebijakan dividend dan good corporate governance saja yang berpengaruh signifikan terhadap nilai perusahaan. Hasil ini konsisten dengan Crutchley dan Hansen (1989) yang mengatakan bahwa jika perusahaan meningkatkan pengeluaran dividen dapat mengurangi biaya keagenan karena pengeluaran dividend menngakibatkan laba ditahan semakin kecil sehingga kebutuhan investasi tambahan dilakukan dengan tambahan penerbitan saham. Penerbitan saham identik dengan peningkatan pengawasan internal oleh investor yang akhirnya dapat meningkatkan nilai perusahaan.

Hasil penelitian ini menemukan bahwa penerapan good corporate governance dan dividend dipercaya mampu meningkatkan nilai perusahaan. Pendapat ini konsisten dengan Harahap (2010) yang menyatakan bahwa hutang, dividend, corporate governance, pertumbuhan perusahaan, kemampu labaan, ukuran perusahaan, umur perusahaan berpengaruh terhadap nilai perusahaan. Tetapi tidak konsisten dengan penelitian yang dilakukan Igbal Bukhori, Raharja (2012 ) yang menyatakan bahwa corporate governance (yang diukur dari ukuran dewan komisaris dan ukuran dewan direksi ) dan size of the firm tidak berpengaruh terhadap kinerja perusahaan yang mengindikasikan bahwa mekanisme perusahaan tidak mampu mempengaruhi baikburuknya kinerja perusahaan. Namun yang membedakan dengan penelitian ini, kinerja yang diukur adalah kinerja keuangan(CFROA ).

Namun secara parsial, kepemilikan oleh manajerial, kepemilikan institusional tidak signifikan mempengaruhi nilai perusahaan. Nilai perusahaan yang digambarkan dengan price book value yang menggambarkan perbandingan antara nilai pasar equity (saham) dengan nilai buku equity (saham ) ternyata tidak dipengaruhi oleh kepemilikan manajerial dan kepemilikan institusional. Dalam kaitan ini, mekanisme pengawasan internal yang ditunjukkan oleh kepemilikan saham oleh manajerial dan institusional tidak menjadi penentuan tinggi atau rendahnya nilai perusahaan. Perubahan nilai pasar saham lebih identik disebabkan oleh faktor non fundamental. Hal ini didukung oleh beberapa penelitian tentang fundamental terhadap harga saham menyebutkan bahwa faktor fundamental tidak berpengaruh terhadap harga saham.

Besarnya kecilnya hutang juga tidak signifikan mempengaruhi nilai perusahaan. Nilai perusahaan tidak dipengaruhi oleh besar kecilnya hutang. Dalam kaitan ini, manajemen menganggap bahwa besarnya hutang justru akan menimbulkan cost of debt yang tinggi yang justru meningkatkan resiko perusahaan bukan meningkatkan nilai perusahaan. Penelitian ini konsisten dengan Jensen(1986) yang menyatakan bahwa penggunaan hutang dapat mengendalikan penggunaan free cash flow secara berlebihan dengan demikian menghindari investasi sia-sia. Penggunaan hutang juga mengakibatkan manajemen lebih berhati-hati karena hutang dapat menyebabkan peningkatan resiko kebangkrutan.

Variabel GCG yang memoderasi " kebijakan hutang dan kebijkan dividen" - terhadap nilai perusahaan juga tidak signifikan. Seperti penjelasan sebelumnya hutang secara langsung tidak mempengaruhi nilai perusahaan, demikian juga hutang yang dimoderasi oleh GCG juga tidak signifikan. Hal ini dapat dijelaskan bahwa nilai perusahaan yang digambarkan dengan PBV, lebih dominan dipengaruhi oleh pergerakan nilai equity yang lebih tinggi sebagai dampak meningkatnya harga pasar saham.

\section{O. Kesimpulan}

Berdasarkan hasil dan pembahasan yang dilakukan dalam penelitian ini terdapat beberapa kesimpulan antara lain ;

1. Kepemilikan saham oleh manajerial secara parsial signifikan positif mempengaruhi kebijakan hutang perusahaan. 
2. Resiko bisnis secara parsial signifikan negatif mempengaruhi kebijakan hutang perusahaan.

3. Profitabilitas secara parsial signifikan negatif dapat mempengaruhi kebijakan hutang perusahaan.

4. Ukuran perusahaan secara parsial positif signifikan mempengaruhi kebijakan hutang perusahaan.

5. Kepemilikan saham oleh intitusional secara parsial tidak mempengaruhi kebijakan hutang.

6. Dividen Payout Ratio secara parsial tidak mempengaruhi mempengaruhi debt to equity ratio.

7. Kepemilikan saham oleh manajerial secara parsial tidak mempengaruhi dividen payout ratio.

8. Resiko bisnis yang diukur melalui penyimpangan (deviasi ) laba kotor dibagi total asset secara parsial tidak mempengaruhi kebijakan dividen.

9. Profitabilitas secara parsial signifikan negatif mempengaruhi kebijakan dividen perusahaan.

10. Ukuran perusahaan secara parsial signifikan positif mempengaruhi kebijakan dividend perusahaan.

11. Kepemilikan saham oleh intitusional secara parsia tidak signifikan mempengaruhi kebijakan dividen perusahaan.

12. Kepemilikan saham oleh manajerial secara tidak signifikan mempengaruhi nilai perusahaan.

13. Kepemilikan saham oleh institusional tidak signifikan mempengaruhi nilai perusahaan.

14. Kebijakan hutang yang diukur dengan proxy DER tidak signifikan mempengaruhi nilai perusahaan.

15. Kebijakan dividen secara parsial signifikan positif mempengaruhi nilai perusahaan.

16. Penerapan good corporate governance secara signifikan positif mempengaruhi nilai perusahaan.

17. Corporate governance yang menjadi variabel moderating antara hutang dgn nilai perusahaan secara parsial tidak signifikan mempengaruhi nilai perusahaan.

18. Corporate governance yang menjadi variabel moderating antara dividen dgn nilai perusahaan secara parsial signifikan tidak mempengaruhi nilai perusahaan. 19.

\section{Q. Saran}

1. Kepada perusahaan yang menjadi objek dalam penelitian ini disarankan untuk mempertimbangkan untuk memperbesar dividend payout ratio-nya karena berdasarkan analisis kebijakan tersebut mampu meningkatkan price book value.

2. Perusahaan juga perlu mempertimbangkan untuk meningkatkan penerapan good corporate governance karena terbukti mampu meningkatkan price book value.

3. Kepada peneliti selanjutnya yang ingin meneliti tentang nilai perusahaan, disarankan untuk memperpanjang periode pengamatan data agar penelitian lebih akurat dan menggali variabel lain agar memperoleh variabel yang lebih kuat yang mampu mempengaruhi nilai perusahaan. 


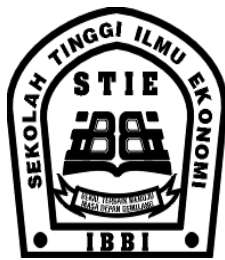

ISSN 1858-3199

JURNAL

MANAJEMEN BISNIS

STIE IBBI

\section{DAFTAR PUSTAKA}

Anissa, Kristina (2012), Majalah SWA edisi XXVII 20 Desember 2012- 9 Januari 2013 No. ISSN 0215-0050

Bathala,C.T., Moon, K.P., and Rao, R.P. (1994), "Managerial Ownership, Debt Policy, and The Impact of Institusional Holding : An Agency Perspective ", Journal of Financial Management, Vol.23, No.3 P.38-50.

Brigham, Eugene F and J.F. Houston ( 2001), Manajemen Keuangan, Edisi VIII, Buku II, Penerbit Erlangga, Jakarta.

Crutchley, C.E., Hansen, R.S. (1989), “ A Test of The Agency Theory of Managerial Ownership, Corporate Leverage, and Corporate Dividends “, Journal Of Financial Management, p3646.

Easterbook, Frank, H. (1984 ), “Two Agency- cost explanation of dividends “, American Economic Review, p.650-659.

Gordon, Myron. J. (1963)," Optimal Investment and Financing Policy “, Journal Of Finance, Mei 1963, p.264-272.

Harahap, Ludwina . ( 2010 ) "Analisis komprehensif pengaruh family ownership, masalah keagenan, kebijakan dividend, kebijakan hutang, corporate governance dan opportunity growth terhadap nilai perusahaan ", Thesis, Universitas Indonesia.

Ho, Simon, S.M. dan Kar Sung Wong (2000), " A study of the relationship between cg structures and the extent of voluntary disclosure", Working Paper

Homaifar,G.J. Ziest, and O. Benkato (1994," An Empirical Model of Capital Structure : Some new evidence", Journal of Business and Accounting Vol 21,p. 1-14.

Indahningrum, Rizka \& Ratih (2009). “ Pengaruh Kepemilikan Manajerial, Kepemilikan Institusional, Dividen, Pertumbuhan Perusahaan, Free Cash Flow dan Profitabilitas Terhadap Kebijakan Hutang Perusahaan", Jurnal Bisnis dan Akuntansi Vol 11 No. 3 Desember 2009, Hal. 189-207.

Jensen, Michael C. dan William H. Meckling (1976)," Theory of the Firm ; Managerial Behavior, Agency Cost, and Ownership Structure", Journal of Financial Economics Vol. 3 No. 4 Hal. 305-360.

Kim,W., and E. Sorensen (1986), "Evidence On The Impact Of The Agency Cost Of Debt On Corporate Debt Policy", Journal Of Financial and Quantitative Analysis, p.247-263.

Khomsiyah (2003)," Hubungan corporate governance dan pengungkapan informasi : pengujian secara simultan “, Simposium Nasional Akuntansi VI 2003 Surabaya.

Lintner, John, (1962)," Dividends, Earnings, leverage, Stock Prices, and The Supply Of Capital to Corporations", Review of Economics and Statistics, p.243-269.

Listyani, Theresia Tyas (2003)," Kepemilikan Manajerial, Kebijakan Hutang, dan Pengaruhnya Terhadap Kepemilikan Saham Institusional ( Studi pada Perusahaan Manufaktur di Bursa Efek Jakarta", Jurnal Maksi Vol 3, Agustus Hal. 98-114.

Machfoedz, Mas'ud, dan Pranata Puspa Midiastuty (2003), "Analisis Hubungan Mekanisme CG dan Indikasi Manajemen Laba “, Simposium Nasional Akuntansi VI 2003 Surabaya.

Masdupi, Erni (2005), " Analisis Dampak Struktur Kepemilikan pada Kebijakan Hutang Dalam Mengontrol Konflik Keagenan “, Jurnal Ekonomi Bisnis Indonesia, Vol. 20, No. 1, Januari, Hal. 57-69.

Meyers,S., and N. Majluf (1984)," Corporate Financing and Investment Decision When Firms Have Information Investor Do Not Have “, Journal Of Financial Economics 13, p. 187-221. 


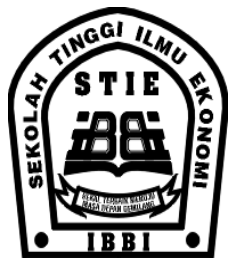

ISSN 1858-3199

JURNAL

MANAJEMEN BISNIS

STIE IBBI

Merton H. dan Franco Modigliani (1961), "Dividend Policy, Growth and The Valuation of Shares", Journal of Business, Oktober 1961,p.411-433.

Puteri, Paramitha Anggia dan Abdul Rohman (2012), " Analisis Pengaruh Investment Opportunity Set (IOS) dan Mekanisme Corporate Governance Terhadap Kualitas Laba dan Nilai Perusahaan", Diponegoro Journal of Accounting, Vol. 1, No. 2, Hal. 1-14.

Rozeff, M, ( 1982), "Growth Beta and Agency Cost as Determinants of Dividend Payout Ratio", Journal of Financial Research, p.249-259.

Sabeni, Arifin (2002), "An Empirical Analysis of the relation between the board of director's composition and the level of voluntary disclosure", Simposium Nasional Akuntansi V di Semarang.

Shleifer, A \& R. Vishny (1986), “ Large Shareholders and Corporate Control “, Journal Of Political Economics , June, p. 461-488.

Siallagan,Hamonangan, Mas'ud Machfoedz (2006), “ Mekanisme Corporate Governance, Kualitas Laba dan Nilai Perusahaan ", Simposium Nasional Akuntansi IX, Padang.

Sukirni, Dwi (2012), “ Kepemilikan Manajerial, Kepemilikan Institusional, Kebijakan Dividend an Kebijakan Hutang Terhadap Nilai Perusahaan”, Accounting Analysis Journal ISSN 22526765, Edisi Nopember.

Soesetio, Yuli (2008 ), "Kepemilikan Manajerial dan Institusional, Kebijakan Dividen, Ukuran Perusahaan, Struktur Aktiva dan Profitabilitas Terhadap Kebijakan Hutang “, Jurnal Keuangan dan Perbankan, Vol 12 No. 3, Hal. 384-398.

Taswan (2003), “ Analisis Pengaruh Insider Ownership, Kebijkan Hutang dan Kebijakan Dividen Terhadap Nilai Perusahaan Serta Faktor-Faktor Yang Mempengaruhinya “, Jurnal Bisnis dan Ekonomi, Edisi September.

Umar, Husein ( 2000), Metode Peneletian Untuk Skripsi dan Tesis Bisnis, Cetakan ke 3, Jakarta : Penerbit Raja Grafindo Persada.

Wahihdahwati (2001), “ Pengaruh Kepemilikan Manajerial dan Kepemilikan Institusional Pada Kebijakan Hutang Perusahaan : Sebuah Perspektif Agency Theory “, Simposium Nasional Akuntansi IV Bandung.

Weston J.F and Brigham E.F.(1994), Dasar-Dasar Manajemen Keuangan, Edisi 9 Jilid 2 Penerbit Erlangga, Jakarta. 


\title{
Pengaruh Nama Merek, Citra Merek, Persepsi Kualitas, Brand Awareness Dan Sikap Konsumen Terhadap Keputusan Pembelian Sabun Pencuci Piring Sunlight Di Medan
}

\author{
Wendi Amsuri Nasution, SE., MM \\ Suryanto Lim, SE., S.Kom \\ Dosen Tetap STIE IBBI Medan
}

\begin{abstract}
ABSTRAK
Didalam menghadapi persaingan usaha yang cukup ketat saat ini, suatu perusahaan tidak cukup hanya dengan menawarkan produk yang memiliki kualitas yang baik, promosi yang menarik, dan pelayanan lainnya untuk menarik minat beli dari konsumen. Perusahaan juga harus menciptakan brand image yang kuat didalam benak konsumen atas merek suatu produk.Telah banyak usaha dilakukan perusahaan dalam memberikan pilihan produknya kepada konsumen, terutama bagi yang mempunyai kesamaan dalam bentuk sebagai pesaing.

Keanekaragaman produk sabun pencuci piring cair yang ada sekarang ini mendorog adanya proses identifikasi para konsumen untuk menentukan salah satu merek yang menurut pandangan mereka memenuhi kriteria sebuah produk sabun pencuci piring cair yang ideal. Sunlight, salah satu merek produk sabun pencuci piring cair yang telah dikenal masyarakat sejak lama. Citra merek dibangun dengan memasukkan 'kepribadian' atau 'citra' kedalam produk untuk kemudian 'dimasukkan' kedalam alam bawah sadar konsumen. Konsumen juga selalu mencari produk yang kira-kira dapat diandalkan, dalam hal ini berkaitan dengan kualitas. Persepsi kualitas terhadap merek menggambarkan respon keseluruhan pelanggan terhadap kualitas dan keunggulan yang ditawarkan merek. Selain itu perlu bagi perusahaan menanamkan kesadaran pada konsumen terhadap merek yang ada (brand awareness), sehingga konsumen mampu mengenali atau mengingat kembali sebuah merek dan mengaitkannya dengan satu kategori produk tertentu.

Sabun cuci khususnya sabun pencuci piring cair untuk beberapa orang mungkin menganggap tidak termasuk sebagai kategori produk pilihan utamanya. Namun seiring perkembangan zaman ingin bersih, sehat dan hemat menjadikan produk ini menjadi salah satu produk yang banyak dibutuhkan. Mengingat kondisi persaingan yang semakin ketat dan tidak ada habisnya dalam upaya perusahaan memperluas pangsa pasarnya, mempengaruhi sikap konsumen melalui daya tarik yang ada dan akhirnya kesediaan konsumen membeli produk-produk mereka. Bagaimana perusahaan mampu mengatasi faktor-faktor yang mempengaruhinya agar mampu menguasai pasar akan memperoleh keuntungan yang lebih.

Tujuan penelitian adalah untuk menganalisis bagaimana vaiabel-variabel tersebut memengaruhi keputusan pembelian Hasil penelitian ini bermanfaat bagi perusahaan dalam menetapkan strategi pasarnya untuk lebih mengetahui faktor-faktor yang dapat mempengaruhi keputusan konsumen sehingga menjadi pemenang pasar dimasa yang akan datang. Bagi akademika, penelitian ini diharapkan mampu menambah khasanah ilmu pengetahuan dan memperluas wawasan dalam bidang Ilmu manajemen pemasaran, khususnya mengenai nama merek, citra merek, persepsi kualitas, brand awareness dan sikap konsumen yang berkenaan dengan keputusan pembelian konsumen terhadap produk sabun pencuci piring cair Sunlight. Sedangkan bagi peneliti lain, hasil penelitian ini diharapkan memberikan gambaran ilmiah tentang faktor perilaku yang mempengaruhi keputusan konsumen yang dapat menjadi informasi kepada penelitian selanjutnya.

Hasil penelitian yang diperoleh dalam penelitian ini menunjukkan bahwa secara parsial nama merek, citra merek, persepsi kualitas dan brand awareness berpengaruh secara positif dan signifikan terhadap keputusan konsumen membeli sabun pencuci piring cair Sunlight.
\end{abstract}




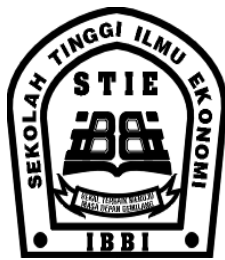

ISSN 1858-3199

JURNAL

MANAJEMEN BISNIS

STIE IBBI

\section{A. Latar Belakang Penelitian}

Didalam menghadapi persaingan usaha yang cukup ketat saat ini, suatu perusahaan tidak cukup hanya dengan menawarkan produk yang memiliki kualitas yang baik, promosi yang menarik, dan pelayanan lainnya untuk menarik minat beli dari konsumen. Perusahaan juga harus menciptakan suatu brand image yang kuat didalam benak konsumen atas merek suatu produk.

Perkembangan dunia usaha yang begitu pesat menyebabkan persaingan antar perusahaan agar mampu tampil di tengah-tengah persaingan tersebut. Dalam pemasaran modern tidak lagi mengacu pada bagaimana produk itu hanya dapat laku terjual kepada konsumen tetapi juga mampu memberikan value added terhadap produk yang dikeluarkan. Telah banyak usaha dilakukan perusahaan dalam memberikan pilihan produknya kepada konsumen, terutama bagi yang mempunyai kesamaan dalam bentuk.

Dahulu orang belum kenal dan familiar dengan sabun pencuci piring khusus sampai pada saatnya seiring waktu muncul sabun pencuci piring cair dengan berbagai merek yang menggeliatkan persaingan diantara merek yang ada. Berbagai macam merek sabun pencuci piring cair pesaing yang muncul dengan janjinya masing.masing. Keanekaragaman produk sabun pencuci piring cair yang ada sekarang ini mendorog adanya proses identifikasi para konsumen untuk menentukan salah satu merek yang menurut pandangan mereka memenuhi kriteria sebuah produk sabun pencuci piring cair yang ideal.

Sunlight merupakan salah satu merek produk sabun pencuci piring cair yang telah dikenal di kalangan masyarakat sejak lama. Selain itu Sunlight telah tertanam kuat dibenak konsumen ketika dihadapkan pada keputusan dalam membeli merek sabun pencuci piring. Citra merek dibangun dengan memasukkan 'kepribadian' atau 'citra' kedalam produk untuk kemudian 'dimasukkan' kedalam alam bawah sadar konsumen.

Konsumen juga selalu mencari produk yang kira-kira dapat diandalkan, atau dalam hal ini berkaitan dengan kualitas. Persepsi kualitas terhadap merek menggambarkan respon keseluruhan pelanggan terhadap kualitas dan keunggulan yang ditawarkan merek. Persepsi konsumen mengenai kualitas merek mungkin dapat tinggi ketika mereka memiliki asosiasi yang kuat dengan merek dan sebaliknya.

Suatu nama merek dapat mengidentifikasikan bagian dari sebuah produk yang dapat diucapkan dan mampu membedakan produk tersebut dari pesaing lainnya. Sebuah nama merek (brand name) dapat memberi rasa nyaman dan percaya bagi pembeli dan yakin atas keputusannya dengan mengurangi persepsi risiko mereka yaitu salah satunya melalui produk dengan nama yang sudah terkenal, karena mereka sudah aware terhadap merek tersebut.

Selain memperkuat nama merek di benak konsumen, perlu bagi perusahaan menanamkan kesadaran pada konsumen terhadap merek yang ada. Brand awareness yang dapat diartikan sebagai kemampuan pelanggan untuk mengenali atau mengingat kembali sebuah merek dan mengaitkannya dengan satu kategori produk tertentu. Dengan demikian, seorang pelanggan yang memiliki kesadaran terhadap sebuah merek akan secara otomatis mampu menguraikan elemen-elemen merek tanpa harus dibantu. Kesadaran merek tertinggi ditandai dengan ditempatkannya merek pada level tertinggi dalam pikiran pelanggan.

Sabun cuci khususnya sabun pencuci piring cair untuk beberapa orang mungkin menganggap bukanlah termasuk ke dalam kategori produk pilihan utamanya. Namun seiring perkembangan zaman yang menuntut orang ingin bersih, sehat dan hemat menjadikan sabun pencuci piring cair menjadi salah satu produk yang banyak dibutuhkan orang bukannya hanya di kalangan masyarakat rumah tangga tapi juga bagi masyarakat kalangan industri dan bisnis. 


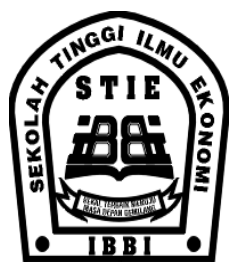

ISSN 1858-3199

JURNAL

MANAJEMEN BISNIS

STIE IBBI

Berdasarkan hal tersebut di atas perlu serkiranya bagi Sunlight menyikapi hal ini. mengingat kondisi persaingan yang semakin ketat dan tidak ada habisnya dalam upaya perusahaan memperluas pangsa pasarnya, mempengaruhi sikap konsumen melalui daya tarik yang ada dan akhirnya kesediaan konsumen membeli produk-produk mereka dan mampu mengatasi faktor-faktor yang mempengaruhinya dan akhirnya mampu menguasai pasar akan memperoleh keuntungan yang lebih.

Maka dalam penelitian ini memfokuskan pada penduduk di Kota Medan umumnya dn ibuibu rumah tangga khususnya yang memakai produk sabun pencuci piring cair Sunlight dalam kehidupan sehari-harinya. Pertimbangan lain bahwa terdapat berbagai latar belakang kebiasaan, sifat, kultur, sosial, dan tingkat ekonomi yang ada di dalamnya sehingga secara tidak langsung mempengaruhi sikap dan pola perilaku mereka dalam kehidupan sehari-hari termasuk dalam hal melakukan pembelian.

Perusahaan berlomba-lomba melakukan berbagai cara untuk dapat menghasilkan produk yang mampu menarik calon pembeli untuk bersedia membeli produk mereka. Perusahaan juga berusaha mencapai pangsa pasar sebesar-besarnya untuk mendapatkan keuntungan yang sebesarbesarnya pula.

\section{B. Perumusan Masalah}

Rumusan masalah yang dikembangkan dalam penelitian ini berdasarkan uraian latar belakang di atas adalah: 'Bagaimana Nama Merek, Citra Merek, Persepsi kualitas, Brand Awareness dan Sikap Konsumen berpengaruh Terhadap Keputusan Pembelian Sabun Pencuci Piring Sunlight di Medan?'.

\section{Tinjauan Pustaka \\ Penelitian Terdahulu}

Lusi Indah Mayasari (2011), dengan penelitiannya yang berjudul "Analisis Penguh Citra Merek, Persepsi terhadap Kualitas, Nama Merek, dan Brand Awareness terhadap Keputusan Pembelian Sabun Pencuci Pakaian Bubuk Attack (Studi Kasus pada Konsumen Produk Attack di Kecamatan Gayamsari, Kota Semarang). Penelitian ini bertujuan untuk mengetahui bagaimana pengaruh variabel-variabel bebas tersebut terhadap variabel terikat. Penelitian ini dilakukan terhadap konsumen sabun pencuci pakaian Attack dengan menggunakan metode Purposive Sampling. Melalui uji t dapat diketahui bahwa keempat variabel independen yang telah diteliti terbukti secara positif dan signifikan mempengaruhi variabel dependen. Angka Adjusted R Square sebesar 0,766 menunjukan bahwa 76,6\% variasi keputusan pembelian dapat dijelaskan oleh variabel independen dalam persamaan regresi. Sedangkan sianya sebesar $23,4 \%$ dipengaruhi oleh variabel lain yang tidak dijelaskan dalam persamaan regresi dalam penelitian ini.

\section{Nama Merek}

Nama merek adalah bagian dari merek dimana bagian dari merek yang dapat disebutkan atau dieja. Nama mengukuhkan sebuah eksistensi antara yang baru lahir dengan yang telah ada. Melalui nama merek yang satu dapat dibedakan dengan merek yang lain atau dengan kata lain nama merek menjadi sesuatu yang penting dalam proses identifikasi (Sadat, 2009).

Knapp dalam Simamora (2002) yang menyebutkan bahwa merek bukan sekedar nama besar kalau sudah terkenal, merek adalah cara hidup dimana didalamnya terdapat keinginan, janji dan komitmen yang harus dipenuhi oleh perusahaan. Oleh karena itu diperlukan adanya lima strategi untuk membentuk merek (nama) yang kuat yaitu : 


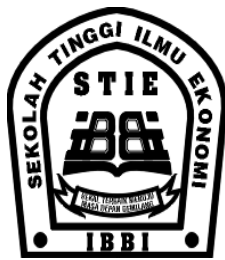

ISSN 1858-3199

JURNAL

MANAJEMEN BISNIS

STIE IBBI

1. Melakukan penilaian merek, hal ini kira-kira sama dengan evaluasi posisi merek yang ada. Merek perlu dipandang sebagai suatu subjek bukan hanya objek, oleh karena itu perlu diketahui faktorfaktor asosiasi yang melekat pada merek sebagai subjek.

2. Mengembangkan janji merek, yaitu harapan tentang bagaimana merek bekerja terhadap konsumen. Dengan sendirinya kalau sudah berjanji, merek akan segera menepatinya.

3. Menciptakan "blueprinte merek yang hampir sama dengan identitas merek yang ada.

4. Membudayakan merek, artinya perlu adanya keterkaitan emosional agar konsumen loyal terhadap merek salah satunya melalui manfaat-manfaat yang memberikan sentuhan emosional.

5. Meningkatkan keuntungan merek.

Upaya menjadikan sebuah brand names itu bagus dimata konsumen dan benak konsumen, setidaknya ada beberapa hal yang perlu diperhatikan (Nicolino, 2004) yaitu mudah diingat, menimbulkan image positif, tidak menyerang etnis, ras, atau kelompok agama tertentu, mudah diucapkan, membentuk suatu kepribadian, berbeda, kedengarannya bagus ketika diucapkan, menggambarkan kelebihan yang dimilik produk, menggambarkan perasaan, menonjol, istimewa.

\section{Hubungan Nama Merek dengan Keputusan Pembelian}

Nicolino (2004) menyebutkan peran-peran nama merek yang ada sekarang meliputi :

1. Memotivasi orang untuk terlibat atau membeli

Nama merek sering kali menjadi alat utama untuk menarik perhatian konsumen. Nama tersebut mampu mengisyaratkan "inilah yang Anda inginkan".

2. Menjadikan produk mudah didapat

Nama merek itu sendiri harus menempel dalam ingatan orang. Banyak cara agar hal itu terjadi, seperti memiliki nama unik dan beda atau nama yang menimbulkan kesan yang meyakinkan. Kuncinya adalah mudah diingat, mimpi buruk seorang pemasar adalah ketika pelanggan yang berkata "saya melihat sesuatu yang saya inginkan dalam iklan tetapi saya tidak tahu mereknya apa".

3. Menciptakan titik fokus

Nama merek harus memberikan daya tarik sentral yang merangkum semuanya. Nama merek harus relevan dengan produk dan fungsinya serta idealnya harus memberi sejenis inspirasi atau petunjuk pada seluruh komunitas merek.

4. Menggambarkan hakikat atau fungsi produk

Untuk yang satu ini tidak selalu berlaku, yang perlu dilakukan adalah mengingat namanya dan mempertimbangkan yang mana. Tetapi untuk beberapa merek, nama menggambarkan segalanya.

5. Menciptakan perasaan atau identifikasi yang positif

Menurut Bouch et.al dalam Sulivan (2001) menyebutkan didalam suatu penelitian eksperimental psikologi menunjukkan bahwa nama merek membantu konsumen dalam mengevaluasi produk serta mengurangi dorongan keraguan dalam memutuskan melakukan pembelian, dikarenakan nama merek mampu memberi rasa aman bagi seorang konsumen.

\section{Citra Merek}

Kotler dalam Farrah (2005) mendefinisikan citra merek sebagai seperangkat keyakinan, ide, dan kesan yang dimiliki oleh seseorang terhadap suatu merek. Oleh karenanya sikap dan tindakan konsumen terhadap suatu merek sangat ditentukan oleh citra merek tersebut. Sementara Dobni dan Zinkhan dalam Hossain (2007) menyatakan bahwa citra merek adalah keseluruhan dari persepsi konsumen mengenai merek atau bagaimana mereka mengetahuinya. Hal tersebut dipertegas oleh 


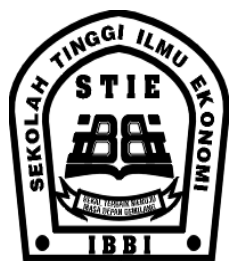

ISSN 1858-3199

JURNAL

MANAJEMEN BISNIS

STIE IBBI

Simamora dalam Farah (2005) bahwa citra adalah persepsi yang relatif konsisten dalam jangka panjang (enduring perception) maka tidak mudah untuk membentuk citra, sehingga bila telah terbentuk akan sulit mengubahnya. Lebih tegasnya citra merek merupakan syarat dari merek yang kuat (Kotler, 2004).

Beberapa faktor pembentuk citra merek (Sciffman dan Kanuk, 2007), sebagai berikut :

1. Kualitas dan mutu, berkaitan dengan kualitas produk barang yang ditawarkan oleh produsen dengan merek tertentu.

2. Dapat dipercaya atau diandalkan, berkaitan dengan pendapat atau kesepakatan yang dibentuk oleh masyarakat tentang suatu produk yang dikonsumsi.

3. Kegunaan atau manfaat, yang terkait dengan fungsi dari suatu produk yang bisa dimanfaatkan oleh konsumen.

4. Pelayanan, yang terkait dengan tugas produsen dalam melayani konsumennya.

5. Resiko, terkait dengan besar kecilnya akibat untung dan rugi yang mungkin dialami oleh konsumen.

6. Harga, yang dalam hal ini berkaitan dengan tinggi rendahnya atau banyak sedikitnya jumlah uang yang dikeluarkan oleh konsumen untuk mempengaruhi suatu produk, juga dapat mempengaruhi citra jangka panjang.

7. Citra yang dimiliki oleh merek itu sendiri, yaitu berupa pandangan, kesepakatan, dan informasi yang berkaitan dengan suatu merek dari produk tertentu.

\section{Hubungan Citra Merek dengan Keputusan Pembelian}

Perusahaan perlu menciptakan posisi merek yaitu melalui citra merek yang diciptakan secara relatif dengan pesaing. Melalui posisi yang dimiliki, merek akan memiliki citra yang jelas, berbeda, dan unggul di benak konsumen (Simamora, 2003). Salah satu cara yang dapat dibangun adalah melalui pembentukan citra yang positif.

Citra merek yang positif dapat membantu konsumen untuk menolak aktivitas yang dilakukan oleh pesaing dan sebaliknya menyukai aktifitas yang dilakukan oleh merek yang disukainya serta selalu mencari informasi yang berkaitan dengan merek tersebut (Schiffman dan Kanuk, 2007).

\section{Persepsi Terhadap Kualitas}

Boyd, et al (2000) menyatakan bahwa: persepsi (perception) adalah proses dengan apa seseorang memilih, mengatur, dan menginterpretasi informasi. Berkowitz, et al (2000) bahwa: perception, the process by which an individual selects, organizes, and interprets information to create a meaningful picture of the world.

Persepsi kualitas terhadap merek menggambarkan respon keseluruhan pelanggan terhadap kualitas dan keunggulan yang ditawarkan merek. Respon ini adalah persepsi yang terbentuk dari pengalaman pelanggan selama berinteraksi dengan merek melalui komunikasi yang dibangun oleh pemasar. Tentu saja kondisi seperti ini harus terus dijaga melalui pengembangan kualitas secara berkesinambungan (Sadat, 2009).

Sedemikian pentingnya peran persepsi terhadap kualitas bagi suatu merek sehingga upaya membangun perceived quality yang kuat perlu memperoleh perhatian serius agar perusahaan dapat merebut dan menaklukkan pasar di setiap kategori. Membangun persepsi terhadap kualitas harus diikuti dengan peningkatan kualitas yang nyata dari produknya karena akan sia-sia meyakinkan pelanggan bahwa kualitas merek produknya adalah tinggi bilamana kenyataan menunjukkan kebalikannya. 


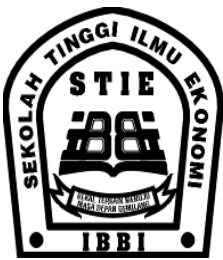

ISSN 1858-3199

JURNAL

MANAJEMEN BISNIS

STIE IBBI

\section{Hubungan Persepsi terhadap Kualitas dengan Keputusan Pembelian}

Menurut Lamb, et al (2001) menyatakan: karakteristik pribadi konsumen - seperti kebutuhan, sikap, kepercayaan, dan pengalaman masa lalu tertentu mereka terhadap kategori produk mempengaruhi informasi yang mereka perhatikan, kuasai dan ingat. Karakteristik pesan itu sendiri dan cara pesan itu disampaikan juga mempengaruhi persepsi konsumen. Proses dimana kita memilih, mengatur dan menginterpretasikan rangsangan (stimulus) kedalam gambaran yang memberi makna dan melekat disebut persepsi. Singkatnya, persepsi adalah cara kita memandang dunia di sekitar kita serta bagaimana kita dapat mengetahui bahwa kita membutuhkan bantuan dalam membuat suatu keputusan pembelian.

Persepsi merupakan realitas yang dinyatakan oleh konsumen dalam membuat keputusan, maka disini persepsi menjadi lebih penting daripada realitas karena konsumen membuat keputusannya berdasarkan persepsi bukan realitas.

\section{Brand Awareness}

Brand awareness dibangun dengan memberikan nama yang baik dan dalam nama itu terkandung makna dan nilai yang begitu tinggi, dimana awareness atas merek dibangun dengan sedemikian baiknya secara terus menerus (continue) sepanjang daur hidup produk itu berlangsung.

Pesan brand awareness dalam membantu suatu merek dapat dipahami bagaimana brand awareness tersebut menciptakan suatu nilai. Nilai-nilai tersebut adalah jangkar yang menjadi pengait bagi asosiasi lain, familiar (menjadi terkenal), komitmen, mempertimbangkan merek (Durianto dkk, 2004).

Upaya untuk dapat meraih, memelihara dan meningkatkan kesadaran perlu adanya, yaitu : menjadi berbeda dan dikenang (be different, memorable), melibatkan sebuah slogan dan jingle (involve a slogan or jingle), menampakkan simbol (symbol expose), publisitas (publicity), sponsor kegiatan (event sponsorship), mempertimbangkan perluasan merek (consider brand extension), serta menggunakan tanda-tanda (using cues) dalam Muafi dan Effendi (2001).

\section{Hubungan Brand Awareness dengan Keputusan Pembelian}

Dengan adanya kesadaran akan merek dapat menggambarkan merek tersebut di dalam pikiran konsumen yang nantinya dapat menjadi penentu dalam beberapa kategori dan mempunyai peranan dalam mempengaruhi keputusan salah satunya dalam hal pembelian.

Kesadaran merek mempengaruhi rasa percaya diri pelanggan atas keputusan pembelian dengan mengurangi tingkat resiko yang dirasakan atas suatu merek yang diputuskan untuk dibeli.

\section{Sikap}

Menurut Lamb, et al (2001): sikap adalah suatu kecenderungan yang dipelajari untuk memberikan respon secara konsisten terhadap suatu obyek yang diberikan, seperti halnya suatu merek. Sikap (attitudes) konsumen adalah faktor penting yang akan mempengaruhi keputusan konsumen.

Mowen dan Minor (2002) menyatakan: tiga mekanisme menjelaskan bagaimana sikap terbentuk secara langsung: proses pembelajaran perilaku, proses yang disebut fenomena exposurenyata, dan suasana hati.

\section{a. Proses Pembelajaran Perilaku dan Formasi Sikap}

Sikap dapat diciptakan secara langsung melalui proses pembelajaran perilaku yang dapat ditimbulkan oleh rangsangan sehingga suatu merek tertentu akan menimbulkan perasaan dan 


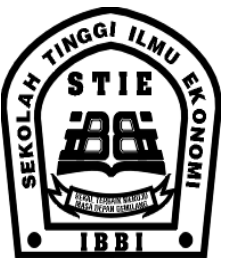

ISSN 1858-3199

JURNAL

MANAJEMEN BISNIS

STIE IBBI

emosi tertentu. Penguatan sosial dapat merupakan faktor utama yang mempengaruhi formasi sikap. Tanggapan positif dari orang lain menghasilkan penguatan evaluasi konsumen biasanya terjadi secara berulang. Tanggapan negatif dari orang lain dapat menghasilkan penghukuman terhadap evaluasi konsumen. Selain itu sikap juga muncul karena konsumen membentuk sikap mereka dengan meniru.

\section{b. Exposure Nyata dan Formasi Sikap}

Kesukaan seseorang akan sesuatu mungkin meningkat karena mereka saling melihatnya. Keberatan merupakan hal yang penting, terutama jika konsumen memandang rangsangan secara negatif, yaitu eksposure berulang mungkin akan mengarah pada rangsangan tidak suka yang hebat.

\section{c. Suasana Hati dan Formasi Sikap}

Suasana hati memiliki dampak langsung terhadap formasi sikap. Suasana hati juga akan mempengaruhi evaluasi: suasana hati yang baik akan meningkatkan peluang evaluasi yang positif, sementara suasana hati yang buruk akan meningkatkan evaluasi yang negatif.

\section{Hubungan Sikap dengan Keputusan Pembelian}

Sikap tergantung pada sistem nilai dari seorang individu yang mewakili standar pribadi tentang baik dan buruk, benar dan salah, dan seterusnya. Pada kenyataannya, keputusan konsumen sangat dipengaruhi oleh sikapnya terhadap produk atau jasa yang akan dikonsumsinya. Sikap positif suatu konsumen terhadap merek akan memungkinkan konsumen melakukan pembelian sedangkan sikap negatif akan menghalangi konsumen dalam melakukan pembelian.

\section{Keputusan Pembelian}

Kotler (2004) menyebutkan bahwa keputusan untuk membeli yang diambil oleh pembeli sebenarnya merupakan kumpulan dari sejumlah keputusan. Setiap keputusan untuk membeli tersebut mempunyai suatu stuktur sebanyak tujuh komponen, yaitu meliputi: Keputusan tentang jenis produk dimana dalam hal ini konsumen dapat mengambil keputusan tentang produk apa yang akan dibelinya untuk memenuhi dan memuaskan kebutuhan; Keputusan tentang bentuk produk, konsumen dapat mengambil keputusan untuk membeli suatu produk dengan bentuk sesuai dengan seleranya; Keputusan tentang merek konsumen harus mengambil keputusan tentang merek mana yang akan dibeli karena setiap merek mempunyai perbedaan-perbedaan tersendiri; Keputusan tentang penjualnya, konsumen dapat mengambil keputusan dimana produk yang dibutuhkan tersebut akan dibeli; Keputusan tentang jumlah produk, konsumen dapat mengambil keputusan tentang seberapa banyak produk yang akan dibeli; Keputusan tentang waktu pembelian, konsumen dapat mengambil keputusan tentang kapan dia harus melakukan pembelian. Oleh karena itu, perusahaan atau pemasar pada khususnya terus mengetahui faktor-faktor yang mempengaruhi keputusan konsumen dalam menentukan waktu pembelian; Keputusan tentang cara pembayaran, konsumen harus mengambil keputusan tentang metode atau cara pembayaran produk yang dibeli, apakah secara tunai atau kredit. Keputusan tersebut akan mempengaruhiu keputusan tentang penjualan dan jumlah pembeliannya.

Menurut Ajzen dan Fishbein dalam Engel dkk (2000) pada umumnya seseorang sangat rasional dalam memanfaatkan informasi yang tersedia serta mempertimbangkan implikasi dari tindakan tersebut sebelum memutuskan untuk terlibat atau tidak dalam perilaku tersebut, dengan kata lain, disini informasi berperan penting.

Kotler (2004) mencatat terdapat beberapa tahapan dalam proses keputusan pembelian yang dilakukan pelanggan, yaitu: 


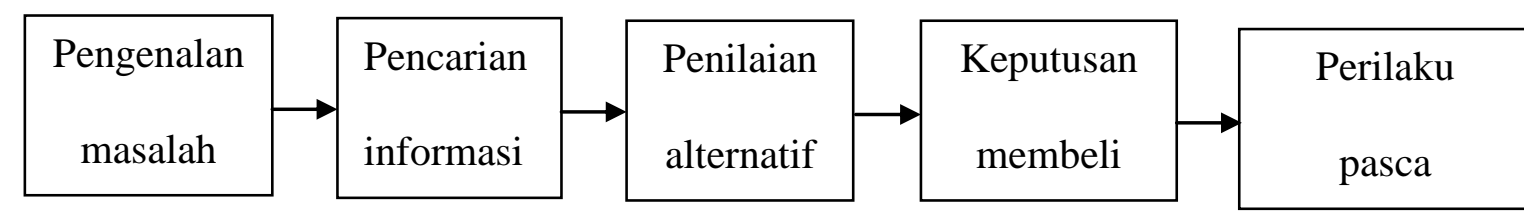

Sumber: Kotler (2004)

\section{Gambar 2.1 Model Lima Tahap Proses Membeli}

a. Pengenalan Kebutuhan

Proses pembelian dimulai ketika seseorang menyadari kebutuhannya. Kebutuhan dapat ditimbulkan oleh rangsangan yang berasal dari dalam maupun dari luar individu.

b. Pencarian Informasi

Ketika seseorang telah sadar akan kebutuhannya, dia akan berusaha mencari informasi tentang bagaimana memenuhi kebutuhannya. Dalam tahap ini konsumen dapat dibedakan menjadi dua level. Yang pertama, heightened attention, konsumen yang termasuk dalam level ini cenderung mau menerima informasi apa saja yang terkait dengan produk yang ingin dibeli. Yang kedua, active information research, konsumen akan secara aktif mencari semua informasi yang terkait dengan produk yang ingin dibeli.

c. Evaluasi Alternatif

Dalam melakukan keputusan pembelian, setiap konsumen normalnya pasti akan berusaha mencari kepuasan. Sehingga dalam mengevaluasi alternative yang didapat dari hasil pencarian informasi, konsumen akan lebih memperhatikan produk yang dapat memberikan kebutuhan yang dicari atau diharapkan oleh konsumen.

d. Keputusan Pembelian

Dalam memutuskan untuk membeli atau tidak membeli, akan ada dua faktor yang mempengaruhi. Yang pertama, attitudes of other, yaitu perilaku seseorang terhadap suatu merek yang mempengaruhi pertimbangan konsumen dalam memilih sutau merek. Yang kedua, unanticipated situational factors, yaitu meliputi kelengkapan suatu produk di dalam pasar.

e. Perilaku Pasca Pembelian

Setelah melakukan pembelian suatu produk, konsumen akan dapat merasakan apakah produk yang dibeli itu memuaskan atau tidak. Maka dari situlah konsumen akan mempertimbangkan apakah akan cukup sampai disitu saja dia berhubungan dengan merek yang telah dibeli (bila tidak puas) atau apakah akan melakukan pembelian ulang ketika dia membutuhkan produk yang sama.

Kotler (2004) menambahkan pada tahap penilaian alternatif, konsumen akan membentuk pilihan mereka diantara beberapa merek yang tergabung dalam perangkat pilihan konsumen, juga akan membentuk suatu maksud beli. Rasa percaya diri konsumen juga turut serta mempengaruhi dalam mengambil keputusan atas pembelian.

\section{Kerangka Konseptual}

Merek adalah nama, istilah, tanda, simbol, atau rancangan atau kombinasi dari hal-hal tersebut yang bertujuan untuk mengidentifikasikan produk atau jasa dari satu atau kelompok penjual dan membedakannya dari produk atau jasa pesaing. Keuntungan pemberian merek pada suatu 


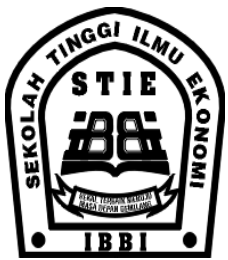

ISSN 1858-3199

JURNAL

MANAJEMEN BISNIS

STIE IBBI

produk bagi konsumen adalah membantu konsumen untuk mengidentifikasikan produk yang diinginkan, selain itu merek juga dapat membantu konsumen untuk mengetahui kualitas, melindungi konsumen karena dari merek dapat diketahui produsen produk. Sikap positif suatu konsumen terhadap merek akan memungkinkan konsumen melakukan pembelian sedangkan sikap negatif akan menghalangi konsumen dalam melakukan pembelian.

Citra merek dibangun dengan memasukkan kepribadian atau citra kedalam produk untuk kemudian dimasukkan ke dalam alam bawah sadar konsumen. Melalui merek yang dibangun secara baik dan melalui citra yang ditampilkan akan semakin memberi rasa kepercayaan yang tinggi bagi konsumen.

Disamping itu, konsumen juga selalu mencari produk yang kira-kira dapat diandalkan, atau dalam hal ini berkaitan dengan kualitas. Persepsi kualitas terhadap merek menggambarkan respon keseluruhan pelanggan terhadap kualitas dan keunggulan yang ditawarkan merek. Respon ini adalah persepsi yang terbentuk dari pengalaman pelanggan selama berinteraksi dengan merek melalui komunikasi yang dibangun oleh pemasar.

Selain memperkuat nama merek dibenak konsumen, perlu bagi perusahaan menanamkan kesadaran pada konsumen terhadap merek yang ada. Brang awareness yang dapat diartikan sebagai kemampuan pelanggan untuk mengenali atau mengingat kembali sebuah merek dan mengaitkannya dengan satu kategori produk tertentu. Dengan demikian, seorang pelanggan yang memiliki kesadaran terhadap sebuah merek akan secara otomatis mampu menguraikan elemen-elemen merek tanpa harus dibantu. Kesadaran merek yang tertinggi ditandai dengan ditempatkannya merek pada level tertinggi dalam pikiran pelanggan. Hal-hal ini dapat mempengaruhi sikpa konsumen berdasarkan pemahaman dan pembelajaran yang terjadi baik disengaja maupun tidak sehingga membentuk suatu keputusan bagi konsumen untuk melakukan suatu tindakan terhadap keputusan pembelian.

Pertimbangan lain bahwa terdapat berbagai hal latar belakang kebiasaan, sifat, kukltur, sosial, dan tingkat ekonomi yang ada di dalamnya sehingga secara tidak langsung mempengaruhi sikap dan pola perilaku mereka dalam kehidupan sehari-hari termasuk juga dalam hal melakukan keputusan pembelian. Sikap positif suatu konsumen terhadap merek akan memungkinkan konsumen melakukan pembelian sedangkan sikap negatif akan menghalangi konsumen dalam melakukan pembelian.

Berdasarkan hal-hal tersebut diatas, maka dapat digambarkan kerangka konseptual dari penelitian ini sebagai berikut:

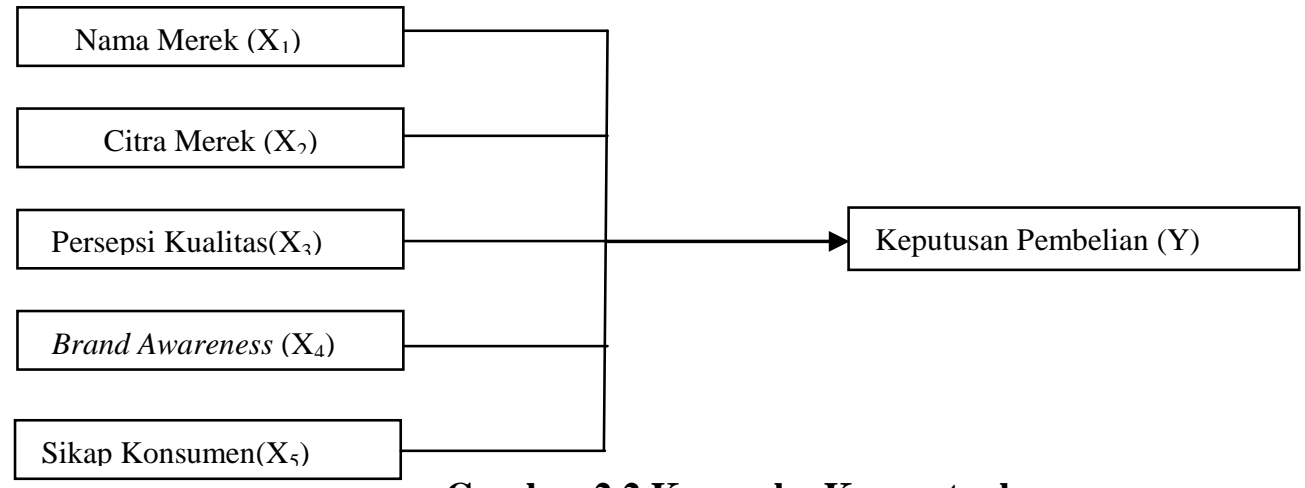

Gambar 2.2 Kerangka Konseptual 


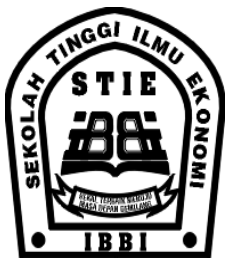

ISSN 1858-3199

JURNAL

MANAJEMEN BISNIS

STIE IBBI

\section{E. Metode Penelitian}

Penelitian dilakukan di Kota Medan, di 21 kecamatan se Kotamadya Medan. Jenis penelitian ini adalah deskriptif kuantitatif, sedangkan sifat penelitian ini adalah deskriptif eksplantori (penjelasan). Penelitian ini menggunakan pendekatan survei dengan mengumpulkan data mengenai faktor-faktor terkait dengan variabel penelitian melalui sampel, untuk menguji pengaruh variabel bebas (nama merek, citra merek, persepsi kualitas brand awareness dan sikap konsumen) terhadap variabel terikat (keputusan pembelian).

Data primer dalam penelitian ini adalah konsumen sebagai populasi yang memakai sabun piring Sunlight yang merupakan penduduk kota Medan sebanyak 2.109.339 jiwa yang berada di 21 kecamatan se kota Medan. Penetapkan sampel menggunakan rumus Slovin (Prasetyo dan Jannah, 2005), dengan nilai kritis sebesar 5\%, jumlah sampel yang dibutuhkan adalah 400 orang ibu rumah tangga pengguna sabun pencuci piring Sunlight di kota Medan. Sampel yang dipilih menggunakan teknik proportionate random sampling. Data yang diperlukan untuk dipergunakan dalam penelitian adalah dengan melakukan wawancara, daftar pertanyaan (questioner), dan studi dokumentasi. Data yang dikumpulkan dalam penelitian ini adalah dengan menggunakan data primer dan data sekunder.

\section{F. Defenisi Operasional Variabel}

\section{Tabel 4.1 Definisi Operasional Variabel}

\begin{tabular}{|c|c|c|c|}
\hline Variabel & Definisi & Indikator & Pengukuran \\
\hline $\begin{array}{l}\text { Nama Merek } \\
\left(\mathrm{X}_{1}\right)\end{array}$ & $\begin{array}{l}\text { Bagian dari suatu merek terdiri dari } \\
\text { kata-kata, huruf atau angka yang } \\
\text { dapat diucapkan yang bersifat } \\
\text { membedakan produk tersebut dari } \\
\text { pesaing }\end{array}$ & $\begin{array}{ll}\text { a. } & \text { Singkat dan sederhana (brevity) } \\
\text { b. Familier } \\
\text { c. Menciptakan perasaan atau identifikasi } \\
\text { positif } \\
\text { d. Sebagai acuan mengevaluasi produk }\end{array}$ & Skala Likert \\
\hline $\begin{array}{l}\text { Citra Merek } \\
\qquad\left(\mathrm{X}_{2}\right)\end{array}$ & $\begin{array}{l}\text { Seperangkat keyakinan, ide, dan } \\
\text { kesan yang dimiliki oleh seseorang } \\
\text { terhadap suatu merek }\end{array}$ & $\begin{array}{l}\text { a. Mengenal merek } \\
\text { b. Merek terpecaya } \\
\text { c. Merek dengan citra kuat (positioning } \\
\text { product) } \\
\text { d. Merek yang peduli perilaku hidup bersih } \\
\text { (concern) }\end{array}$ & Skala Likert \\
\hline $\begin{array}{l}\text { Persepsi } \\
\text { kualitas } \\
\left(\mathrm{X}_{3}\right)\end{array}$ & $\begin{array}{l}\text { Persepsi pelanggan terhadap } \\
\text { keseluruhan atau keunggulan dari } \\
\text { suatu produk yang berkaitan dengan } \\
\text { apa yang diharapkan oleh pelanggan }\end{array}$ & $\begin{array}{l}\text { a. Bahan baku berkualitas } \\
\text { b. Jarang terjadi kerusakan / cacat produk } \\
\text { c. Mampu membersihkan kotoran, kuman dan } \\
\text { lemak sisa makanan } \\
\text { d. Harum }\end{array}$ & Skala Likert \\
\hline $\begin{array}{c}\text { Brand } \\
\text { Awerness } \\
\quad\left(\mathrm{X}_{4}\right)\end{array}$ & $\begin{array}{l}\text { Kekuatan sebuah merek dalam } \\
\text { pikiran (ingatan) konsumen }\end{array}$ & $\begin{array}{ll}\text { a. } & \text { Kemampuan mengingat slogan/jingle } \\
\text { b. Keduk } \\
\text { c. Kemampuan mengenali ikon (duta) produk } \\
\text { d. Kemampuan mengingat promo produk } \\
\end{array}$ & Skala Likert \\
\hline Sikap $\left(X_{5}\right)$ & $\begin{array}{l}\text { Perbuatan yang berdasarkan pada } \\
\text { pendirian (pendapat atau keyakinan) }\end{array}$ & $\begin{array}{ll}\text { a. Keyakinan membeli produk } \\
\text { b. Kepercayaan melakukan pembelian ulang / } \\
\text { membeli kembali produk } \\
\text { c. Komitmen untuk tetap membeli produk }\end{array}$ & Skala Likert \\
\hline $\begin{array}{l}\text { Keputusan } \\
\text { Membeli } \\
\text { (Y) }\end{array}$ & $\begin{array}{l}\text { Tindakan nyata dari konsumen } \\
\text { untuk membeli Sunlight atas dasar } \\
\text { kecocokan dan kepuasan dari apa } \\
\text { yang dicari dan dibutuhkan }\end{array}$ & $\begin{array}{ll}\text { a. } & \text { Prioritas pembelian } \\
\text { b. Keyakinan dalam membeli } \\
\text { c. Kemudahan mendapatkan / memperoleh } \\
\text { d. }\end{array}$ & Skala Likert \\
\hline
\end{tabular}




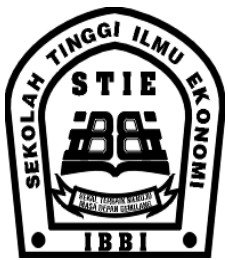

ISSN 1858-3199

JURNAL

MANAJEMEN BISNIS

STIE IBBI

\section{G. Model Analisis Data}

Penelitian ini menggunakan model Analisis Regresi Linier Berganda (Multiple Regression Analysis), dengan persamaan sebagai berikut: $\mathrm{Y}=\mathrm{b}_{0}+\mathrm{b}_{1} \mathrm{X}_{1}+\mathrm{b}_{2} \mathrm{X}_{2}+\mathrm{b}_{3} \mathrm{X}_{3}+\mathrm{b}_{4} \mathrm{X}_{4}+\mathrm{b}_{5} \mathrm{X}_{5}+\mathrm{e}$

\section{H. Hasil dan Pembahasan \\ Hasil Analisis Data}

Tabel 5.3 Hasil Regresi Linier Berganda

\begin{tabular}{|c|c|c|c|c|c|c|c|}
\hline \multirow[b]{2}{*}{ Model } & \multicolumn{2}{|c|}{$\begin{array}{c}\text { Unstandardized } \\
\text { Coefficients }\end{array}$} & \multirow{2}{*}{$\begin{array}{c}\begin{array}{c}\text { Standardized } \\
\text { Coefficients }\end{array} \\
\text { Beta }\end{array}$} & \multirow[b]{2}{*}{$\mathrm{t}$} & \multirow[b]{2}{*}{ Sig. } & \multicolumn{2}{|c|}{ Collinearity Statistics } \\
\hline & B & Std. Error & & & & Tolerance & VIF \\
\hline 1 (Constant) & 6.910 & 1.111 & & 6.221 & .000 & & \\
\hline Nama_Merek & .263 & .044 & .267 & 5.993 & .000 & .874 & 1.144 \\
\hline Citra_Merek & .195 & .041 & .212 & 4.725 & .000 & .861 & 1.162 \\
\hline Persepsi_Kualitas & .216 & .044 & .210 & 4.920 & .000 & .953 & 1.049 \\
\hline Brand_Awareness & .199 & .040 & .218 & 5.028 & .000 & .925 & 1.081 \\
\hline Sikap_Konsumen & -.177 & .031 & -.247 & -5.682 & .000 & .921 & 1.085 \\
\hline
\end{tabular}

a. Dependent Variable: Keputusan_Membeli

Sumber: Data Diolah (2013)

Dari Tabel 5.3 tersebut dapat diperoleh hasil persamaan regresi linier berganda pada permasamaan ini:

$$
\mathrm{Y}=6,910+0,263 \mathrm{X}_{1}+0,195 \mathrm{X}_{2}+0,216 \mathrm{X}_{3}+0,199 \mathrm{X}_{4}-0,177 \mathrm{X}_{5}
$$

Pada persamaan tersebut dapat dilihat bahwa nama merek $\left(\mathrm{X}_{1}\right)$, citra merek $\left(\mathrm{X}_{2}\right)$, persepsi kualitas $\left(\mathrm{X}_{3}\right)$, dan brand awareness $\left(\mathrm{X}_{4}\right)$ berpengaruh positif terhadap naik turunnya variable terikat yaitu keputusan memilih $(\mathrm{Y})$, sedangkan sikap konsumen $\left(\mathrm{X}_{5}\right)$ berpengaruh negatif. Hal ini karena walaupun sudah ada persepsi kualitas yang baik tapi konsumen mengganggap bahwa selain Sunlight masih banyak jenis produk dengan merek yang lain yang dapat digunakan sebagai sabun pencuci piring. Terutama masih ada kawasan yang tidak familiar atau biasa dengan merek Sunlight ini. Dengan melihat koefisien persamaan regresi linier berganda, bahwa masing-masing variabel bebas mempunyai kontribusi terhadap naik atau turunnya variabel terikat.

Untuk mengukur besarnya pengaruh variabel nama merek $\left(\mathrm{X}_{1}\right)$, citra merek $\left(\mathrm{X}_{2}\right)$, persepsi kualitas $\left(\mathrm{X}_{3}\right)$, brand awareness $\left(\mathrm{X}_{4}\right)$ dan sikap konsumen $\left(\mathrm{X}_{5}\right)$ terhadap keputusan konsumen membeli $(\mathrm{Y})$ dapat dilihat dari nilai koefisien determinasi $\left(\mathrm{R}^{2}\right)$ pada Tabel di bawah ini:

Tabel 5.4 Hasil Uji Determinasi

\begin{tabular}{|c|c|c|c|c|c|c|c|c|c|}
\hline \multirow[b]{2}{*}{ Model } & \multirow[b]{2}{*}{$\mathrm{R}$} & \multirow[b]{2}{*}{ R Square } & \multirow[b]{2}{*}{$\begin{array}{c}\text { Adjusted R } \\
\text { Square }\end{array}$} & \multirow[b]{2}{*}{ Std. Error of the Estimate } & \multicolumn{5}{|c|}{ Change Statistics } \\
\hline & & & & & $\begin{array}{l}\text { R Square } \\
\text { Change }\end{array}$ & F Change & df1 & df 2 & Sig. F Change \\
\hline 1 & $.561^{\mathrm{a}}$ & .314 & .306 & 2.161 & .314 & 36.113 & 5 & 394 & .000 \\
\hline
\end{tabular}

a. Predictors: (Constant), Sikap_Konsumen, Persepsi_Kualitas, Brand_Awareness, Nama_Merek, Citra_Merek

b. Dependent Variable: Keputusan_Membeli

Sumber: Data Diolah (2013) 


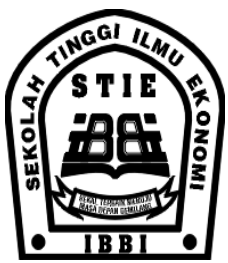

ISSN 1858-3199

JURNAL

MANAJEMEN BISNIS

STIE IBBI

Berdasarkan Tabel 5.4 tersebut dapat dilihat bahwa nilai koefisien $\mathrm{R}$ squarenya adalah 0,314 atau 31,4\%. Dengan demikian menunjukkan bahwa 31,4\% variabel terikat yaitu keputusan membeli (Y) dapat dijelaskan oleh nama merek $\left(\mathrm{X}_{1}\right)$, citra merek $\left(\mathrm{X}_{2}\right)$, persepsi kualitas $\left(\mathrm{X}_{3}\right)$, brand awaeness $\left(\mathrm{X}_{4}\right)$ dan sikap konsumen $\left(\mathrm{X}_{5}\right)$, sedangkan sisanya sebesar 68,6\% merupakan variabel lain yang tidak diteliti dalam model penelitian ini seperti gaya hidup, kelas sosial, kelompok rujukan, motivasi dan factor internal dan eksternal lainnya dari perilaku konsumen.

\section{Uji Simultan (Uji F)}

Hipotesis penelitian yang dipergunakan uji simulttan $(\mathrm{F})$, yaitu:

$\mathrm{H}_{0}: \mathrm{b}_{1}, \mathrm{~b}_{2}, \mathrm{~b}_{3}, \mathrm{~b}_{4}, \mathrm{~b}_{5}=0$ (nama merek, citra merek, persepsi kualitas, brand awareness, dan sikap konsumen secara bersama-sama tidak berpengaruh terhadap keputusan membeli konsumen)

$\mathrm{H}_{1}: \mathrm{b}_{1}, \mathrm{~b}_{2}, \mathrm{~b}_{3}, \mathrm{~b}_{4}, \mathrm{~b}_{5} \neq 0$ (nama merek, citra merek, persepsi kualitas, brand awareness, dan sikap konsumen secara bersama-sama berpengaruh terhadap keputusan membeli konsumen

Dengan kriteriapengambilan keputusan:

$\mathrm{H}_{0}$ diterima jika $\mathrm{F}_{\text {hitung }}<\mathrm{F}_{\text {tabel }}$ pada $\alpha=5 \%$,

$\mathrm{H}_{0}$ ditolak $\left(\mathrm{H}_{1}\right.$ diterima $)$ jika $\mathrm{F}_{\text {hitung }}>\mathrm{F}_{\text {tabel }}$ pada $\alpha=5 \%$.

Tabel 5.5 Hasil Uji Simultan

\begin{tabular}{|ll|r|r|r|c|c|}
\hline \multicolumn{1}{|l|}{ Model } & & Sum of Squares & df & Mean Square & F & \multicolumn{1}{c|}{ Sig. } \\
\hline 1 & Regression & 843.059 & 5 & 168.612 & 36.113 & $.000^{\mathrm{a}}$ \\
& Residual & 1839.581 & 394 & 4.669 & & \\
& Total & 2682.640 & 399 & & & \\
\hline
\end{tabular}

a. Predictors: (Constant), Sikap_Konsumen, Persepsi_Kualitas, Brand_Awareness, Nama_Merek, Citra_Merek

b. Dependent Variable: Keputusan_Membeli

Sumber: Data Diolah (2013)

Dari Tabel 5.5 berdasarkan hasil pengolahan data dapat diperoleh nilai $\mathrm{F}_{\text {hitung }}$ sebesar 36,113 dengan signifikansi 0,000 . Dengan nilai $F_{\text {tabel }}$ pada tingkat kepercayaan 95\% $(\alpha=0,05)$ maka diperoleh nilai $F_{\text {tabel }} 0,05(4 ; 389)=2,394$. Dengan demikian $F_{\text {hitung }}>F_{\text {tabel }}$, yaitu 36,113 > 2,394 Oleh karena itu maka $\mathrm{H}_{0}$ ditolak dan $\mathrm{H}_{1}$ diterima, yang berarti nama merek $\left(\mathrm{X}_{1}\right)$, citra merek $\left(\mathrm{X}_{2}\right)$, persepsi kualitas $\left(\mathrm{X}_{3}\right)$, brand awareness $\left(\mathrm{X}_{4}\right)$ dan sikap konsumen $\left(\mathrm{X}_{5}\right)$ berpengaruh highly significant terhadap keputusan konsumen membeli $(\mathrm{Y})$ sabun pencuci piring cair Sunlight. Berdasarkan hasil yang telah diperoleh juga dapat dilihat bahwa nilai signifikansi pada uji simultan yaitu 0,000 yang lebih kecil dari pada $\alpha=0,05$. Maka highly significant menunjukkan bahwa nama merek, citra merek, persepsi kualitas, brand awareness, dan sikap konsumen secara bersama-sama sangat berpengaruh secara nyata terhadap keputusan konsumen membeli sabun pencuci piring merek Sunlight, dengan demikian citra merek akan mempengaruhi persepsi kualitas terhadap nama merek suatu produk dan menumbuhkan brand awareness yang baik di benak konsumen walaupun kadang tidak ditunjukkan oleh sikap secara langsung. Karena pada umumnya konsumen sudah kenal baik dengan merek Sunlight, karena merek ini merupakan merek perintis untuk sabun cair pencuci piring. Ada hal-hal yang membuat konsumen tidak mengambil sikap secara langsung, 


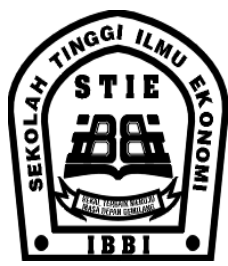

ISSN 1858-3199

JURNAL

MANAJEMEN BISNIS

STIE IBBI

seperti harga dari produk. Karena ada juga konsumen apalagi ibu rumah tangga dalam hal ini sebagai responden menganggap bahwa sabun pencuci piring cair Sunlight bukanlah satu-satunya sabun pencuci piring yang bisa membantu mereka terhadap kebutuhan sehari-hari dalam rumah tangga. Tetapi mereka menyadari bahwa Sunlight merupakan sabun pencuci piring cair yang sudah ternama dan mempunyai tempat di hati dan pikiran konsumen pada umumnya.

Hasil penelitian menunjukkan bahwa konsumen memutuskan membeli sabun pencuci piring cair Sunlight karena persepsi kualitas yang muncul dari produk ini sesuai dengan kualitas yang diharapkan oleh konsumen. Dengan kata lain merek Sunlight dari produk sabun pencuci piring cair ini dianggap sebagai salah satu sabun pencuci piring yang mampu membersihkan dengan bersih peralatan rumah tangga sehingga membantu konsumen mengatasi masalahnya. Dari segi harga yang ditawarkan untuk sebagian ibu rumah tangga mengganggap adalah harga yang wajar dengan kualitas yang dihasilkan. Terlebih opini masyarakat atau konsumen pada umumnya yang menganggap semua sabun pencuci pirig cair itu identik dengan Sunlight. Bahwa nama merek akan membawa terhadap citra produk dan mengarah kepada persepsi dari konsumen. Sehingga pada saat muncul persepsi kualitas yang positif dengan sendirinya akan mempengaruhi keputusan konsumen untuk mengkonsumsinya.

\section{Uji Parsial (Uji t)}

Hipotesis penelitian yang digunakan dalam uji ini adalah:

$\mathrm{H}_{0}: \mathrm{b}_{\mathrm{i}}=0$; (Faktor-faktor yang terdiri dari nama merek, citra merek, persepsi kualitas, brand awareness dan sikap konsumen tidak berpengaruh secara parsial terhadap keputusan membeli konsumen)

$\mathrm{H}_{1}: \mathrm{b}_{\mathrm{i}} \neq 0$; (Faktor-faktor yang terdiri dari nama merek, citra merek, persepsi kualitas, brand awareness dan sikap konsumen berpengaruh secara parsial terhadap keputusan membeli konsumen)

Dengan ketentuan pengambilan keputusan sebagai berikut:

$\mathrm{H}_{0}$ diterima jika $-\mathrm{t}_{\text {tabel }} \leq \mathrm{t}_{\text {hitung }} \leq \mathrm{t}_{\text {tabel }}$ pada $\alpha=5 \%$

$\mathrm{H}_{0}$ ditolak $\left(\mathrm{H}_{1}\right.$ diterima $)$ jika $\mathrm{t}_{\text {hitung }}<-\mathrm{t}_{\text {tabel }}$ atau $\mathrm{t}_{\text {hitung }}>\mathrm{t}_{\text {tabel }}$ pada $\alpha=5 \%$

Hasil uji t (Uji Parsial) dapat dilihat pada Tabel sebelumnya, bahwa secara parsial menunjukkan hasil dari nilai $t_{\text {hitung }}$ setiap variabel bebas. Nilai $t_{\text {hitung }}$ akan dibandingkan dengan nilai $\mathrm{t}_{\text {tabel }}$ pada tingkat kepercayaan $95 \%(\alpha=0,05)$ diperoleh nilai $\mathrm{t}_{\text {tabel }}=1,96$. Untuk variabel nama merek $\left(\mathrm{X}_{1}\right)$ diperoleh nilai $\mathrm{t}_{\text {hitung }} 5,993$, karena $\mathrm{t}_{\text {hitung }}>\mathrm{t}_{\text {tabel }}$ yaitu 5,993 $>1,96$, maka $\mathrm{H}_{0}$ ditolak dan $\mathrm{H}_{1}$ diterima, berarti nama merek berpengaruh terhadap keputusan membeli konsumen. untuk melihat signifikasni dari variabel nama merek diperoleh tingkat signifikansi 0,000 jika dibandingkan dengan tingkat kepercayaan 95\% $(\alpha=0,05)$, dengan demikian variabel nama merek dalam penelitian ini signifikan karena nilai signifikan $0,000<0,05$. Dari persamaan regresi linier sebelumnya menunjukkan bahwa koefisien regresi nama merek $\left(\mathrm{X}_{1}\right)$ mempunyai tanda positif, yang menunjukkan bahwa nama merek yang singkat, sederhana, sering terdengar, mampu menciptakan pemikiran yang positif dan menjadi tolak ukur evaluasi produk untuk melakukan keputusan pembelian (Y) terhadap produk sabun pencuci piring cair Sunlight dan kemudahan memperolehnya dan lebih tersebar baik di toko modern maupun tradisional. Terlebih konsumen yang mengidentikkan produk lain sebagai produk ini.

Pengaruh parsial dari variabel citra merek $\left(\mathrm{X}_{2}\right)$ diperoleh dengan nilai $\mathrm{t}_{\text {hitung }}$ sebesar 4,725 , yang dengan demikian $t_{\text {hitung }}>t_{\text {tabel }}$ yaitu 4,725 $>1,96$, maka $\mathrm{H}_{0}$ ditolak dan $\mathrm{H}_{1}$ diterima. Dengan demikian variabel citra merek berpengaruh terhadap variabel keputusan konsumen membeli (Y) sabun pencuci piring cair Sunlight. Untuk melihat signifikasni dari variabel citra merek diperoleh 


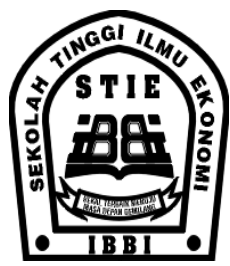

ISSN 1858-3199

JURNAL

MANAJEMEN BISNIS

STIE IBBI

nilai 0,000 , jika dibandingkan dengan tingkat kepercayaan $95 \%(\alpha=0,05)$ bahwa variabel citra merek dalam hal ini mempunyai pengauh signifikan karerna nilai signifikansi $0,000<0,05$. Dari koefisien regresi yang menunjukkan tanda positif, hal ini menunjukkan bahwa nama merek akan membawa citra yang kuat pada saat merek tersebut mampu memberikan sesuai dengan dengan harapan konsumen sehingga dapat dipercaya dan diperoleh mampu menciptakan pengaruh citra merek terhadap perilaku yang bersih dan sehat. Hal ini juga akan meningkatkan permintaan akan Sunight tersebut karena sudah mendapatkan citra yang baik di kalangan konsumen.

Variabel persepsi kualitas $\left(\mathrm{X}_{3}\right)$ diperoleh dengan nilai $\mathrm{t}_{\text {hitung }}$ sebesar 4,920 dengan demikian $t_{\text {hitung }}>t_{\text {tabel }}$ yaitu 4,920 >1,96, sehingga $\mathrm{H}_{0}$ ditolak dan $\mathrm{H}_{1}$ diterima, bahwa variabel persepsi kualitas berpengaruh secara signifikan terhadap keputusan konsumen membeli (Y) sabun pencuci piring Sunlight. Untuk melihat signifikansi dari variabel persepsi kualitas diperoleh nilai signifikansi 0,000 jika dibandingkan dengan tingkat kepercayaan 95\% $(\alpha=0,05)$, dengan demikian variabel persepsi kualitas dalam penelitian ini mempunyai pengaruh signifikan karena nilai signifikansi $0,000>0,05$. Dari persamaan regresi linier berganda yang diperoleh bahwa variabel persepsi kualitas $\left(\mathrm{X}_{3}\right)$ bertanda positif.

Pengaruh parsial dari variabel brand awareness $\left(\mathrm{X}_{4}\right)$ diperoleh dengan nilai $\mathrm{t}_{\text {hitung }}$ sebesar 5,028 dengan demikian $t_{\text {hiutng }}>t_{\text {tabel }}$ yaitu 5,028 $>1,96$, dengan demikian $\mathrm{H}_{0}$ di tolak dan $\mathrm{H}_{1}$ di terima, bahwa variabel brand awareness berpengaruh terhadap variabel keputusan membeli konsumen (Y) sabun pencuci piring cair Sunlight. Untuk melihat signifikansi dari variabel brand awareness diperoleh tingkat signifikans 0,000 jika dibandingkan dengan tingkat kepercayaan 95\% $(\alpha=0,05)$, dengan demikian variabel brand awareness dalam penelitian ini mempunyai pengaruh yang signifikan karena nilai signifikansi $0,000<0,05$ dan pada persamaan regresi linier berganda variabel ini bertanda positif.

Variabel sikap konsumen $\left(\mathrm{X}_{5}\right)$ secara parsial berpengaruh dengan nilai $\mathrm{t}_{\text {hitung }}$ sebesar $-5,628$ dengan demikian nilai $\mathrm{t}_{\text {hitung }}<\mathrm{t}_{\text {tabel }}$ yaitu $-5,628<1,96$ maka $\mathrm{H}_{0}$ diterima dan $\mathrm{H}_{1}$ ditolak. Oleh karena itu karena dalam persamaan regresi linier berganda juga bertanda negatif maka dalam hal ini variabel sikap konsumen tidak berpengaruh terhadap keputusannya membeli (Y) sabun pencuci piring cair Sunlight. Jika dibandingkan dengan tingkat kepercayaan 95\% $(\alpha=0,05)$ maka variabel sikap konsumen dalam hal ini tidak berpengaruh secara signifikan. Signifikansi dari variabel sikap konsumen adalah 0,000 dimana 0,000 $<0,05$.

\section{Hasil Uji Autokorelasi}

Uji autokorelasi ini untuk melihat ada tidaknya autokorelasi dalam suatu model regresi. Untuk menguji apakah dalam model regresi tedapat korelasi antara kesalahan pengganggu pada periode $\mathrm{t}$ dengan kesalahan pengganggu pada periode $\mathrm{t}-1$ (sebelumnnya). Model regresi yang baik adalah regresi yang bebas dari autokorelasi. Dalam hal ini dengan menggunakan uji Durbin-Watson (DW test). Besaran nilai Durbin-Watson (DW)berada diantara -2 sampai +2 , menunjukkan tidak terjadi autokorelasi, dan pada besaran nilai DW $<2$ dan DW $>2$ maka dapat dikatakan terjadi autokorelasi.

Tabel. 5.6 Hasil Uji Autokorelasi

\begin{tabular}{|l|r|r|r|r|r|}
\hline Model & \multicolumn{1}{|c|}{$\mathrm{R}$} & \multicolumn{1}{|c|}{ R Square } & Adjusted R Square & $\begin{array}{c}\text { Std. Error of the } \\
\text { Estimate }\end{array}$ & Durbin-Watson \\
\hline 1 & $.561^{\mathrm{a}}$ & .314 & .306 & 2.161 & 1.551 \\
\hline
\end{tabular}

a. Predictors: (Constant), x5, x3, x4, x1, x2

b. Dependent Variable: y 


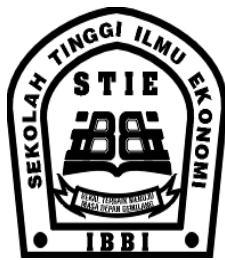

ISSN 1858-3199

JURNAL

MANAJEMEN BISNIS

STIE IBBI

Pada Tabel 5.6 tersebut dapat dilihat bahwa nilai DW pada model regresi ini berada diantara nilai -2 sampai dengan +2 , dengan demikian pada model ini tidak terjadi autokorelasi.

\section{Hasil Uji Multikolonieritas}

Uji multikolonieritas bertujuan untuk menguji apakah pada model regresi ditemukan bahwa adanya korelasi antar variabel bebas. Model regresi yang baik seharusnya tidak terjadi korelasi di antara variabel independent, jika terjadi korelasi maka terdapat masalah multikolonieritas sehingga model regresi tidak dapat dipergunakan. Adanya multikolonieritas dapat dilihat dari tolerance value atau nilai Variance Inflation Factor (VIF). Batas tolerance value adalah 0,1 dan batas VIF adalah 10. Dimana: Tolarance value $<0,1$, atau VIF > 10 maka terjadi multikolonieritas. Tolarance value $>0,1$, atau VIF < 10 maka tidak terjadi multikolonieritas. Hasil pengujian multikolonieritas pada penelitian ini dapat diliihat kembali pada Tabel 5.3, yang menunjukkkan bahwa variabel bebas (nama merek, citra merek, persepsi kuaitas, brand awareness, dan sikap konsumen) memiliki nilai tolerance $>0,1$ atau nilai VIF $<10$, maka dapat disimpulkan bahwa pada model regrei pada penelitian ini tidak terjadi multikolonieritas.

\section{Hasil Uji Normalitas}

\section{Analisis Grafik}

Hasil pengujian normalitas dengan menggunakan analisis grafik dapat dilihat pada Gambar 5.1 dan

\section{2 berikut:}

\section{Normal P-P Plot of Regression Standardized Residual}

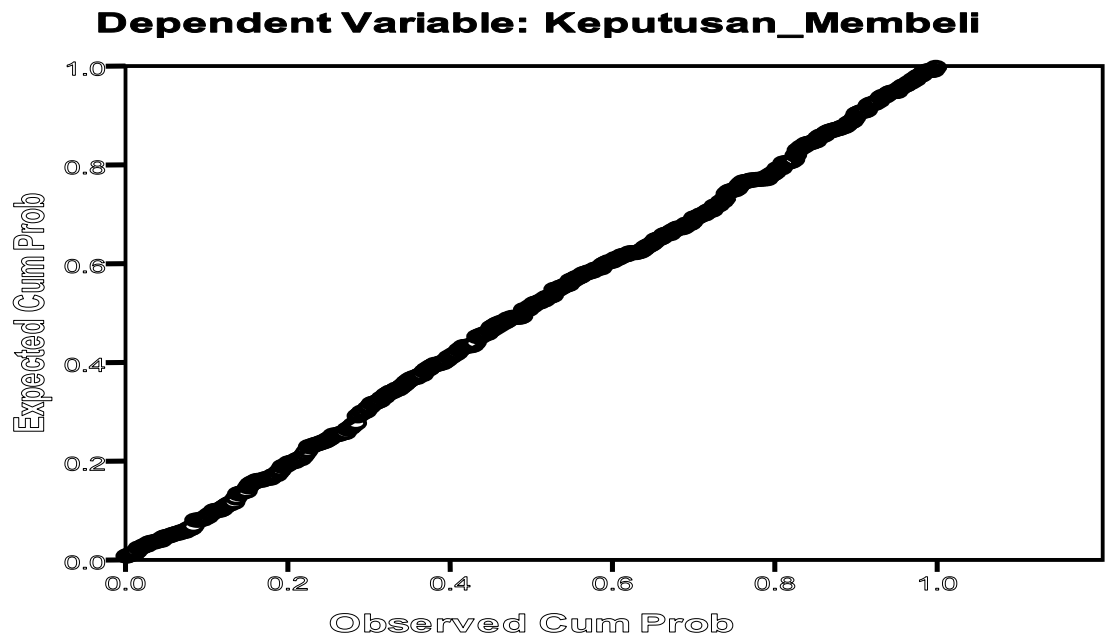

Sumber: Data Diolah (2013)

Gambar 5.1 Grafik Normal P-P Plot 
Dari Gambar 5.1 terlihat bahwa titik-titik data menyebar berhimpit di sepanjang garis diagonal dan mengikuti arah garis diagonal. Hal ini berarti bahwa data berdistribusi normal, maka model regresi memenuhi asumsi normal.

\section{Histogram}

\section{Dependent Variable: Keputusan_Membeli}

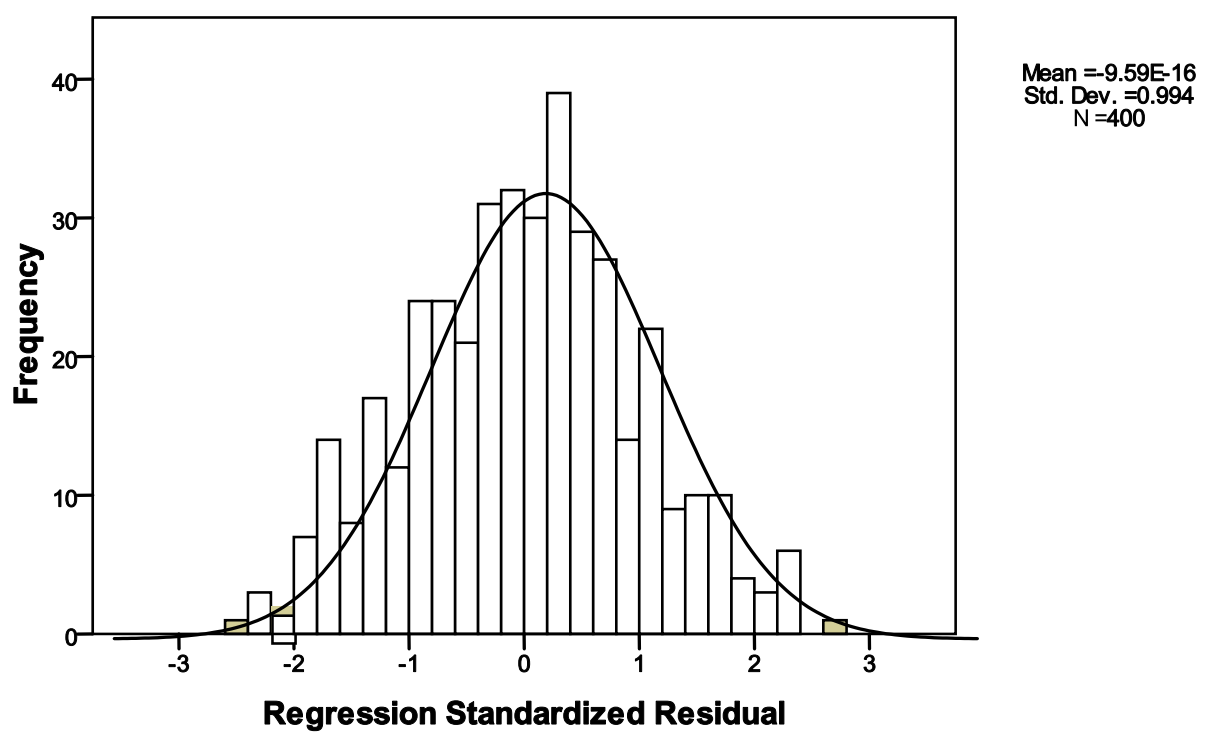

Sumber: Data Diolah (2013)

\section{Gambar 5.2 Grafik Histogram}

Pada gambar menunjukkan bahwa residual terdistribusi secara normal dan berbentuk simetris tidak menceng ke kiri atau ke kanan. Berdasarkan grafik histogramnya menunjukkan pola distribusi normal.

\section{Hasil Uji Heterokedastisitas}

Uji heterokedastisitas bertujuan untuk menguji apakah dalam model regresi terjadi ketidaksamaan varians (terjadi heterokedastisitas) dari residual satu pengamatan ke pengamatan yang lain yang perlu dihindari, karena dalam analisis regresi yang diinginkan adalah data memilliki varians yang sama.

Dalam hal ini hasil uji heterokedatisitas dapat dilihat berdasarkan analisis grafik yang dapat dilihat pada Gambar berikut ini: 


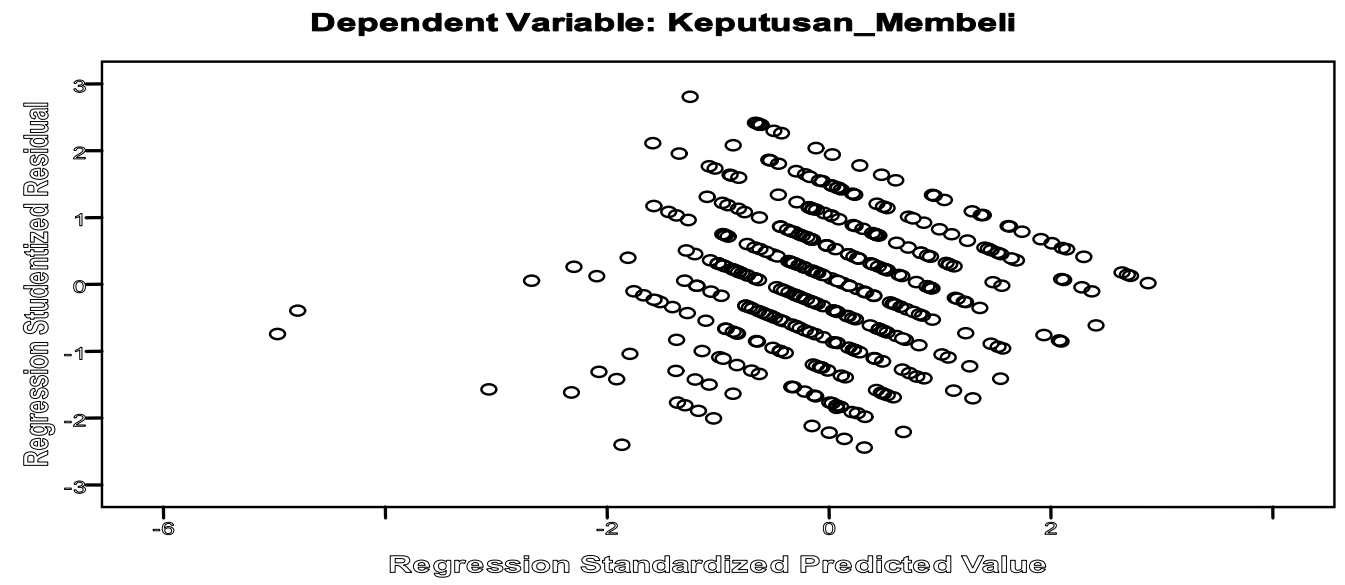

Sumber: Data Di Olah, 2013

\section{Gambar 5.3 Grafik Hasil Uji Heterokedastisitas}

Dari Gambar 5.3 tersebut dapat dilihat bahwa tidak ada pola yang jelas, serta titiktitik yang mmenyebar di atas dan di bawah angka 0 pada sumbu Y, sehingga dapat disimpulkan bahwa pada model regresi tidak terjadi heterokedastisitas.

\section{Pembahasan}

Berdasarkan hasil analisis dari penelitian ini dapat diketahui bahwa secara serempak variabel bebas yang terdir dari nama merek, citra merek, persepsi kualitas, brand awareness, dan sikap konsumen berpengaruh terhadap keputusan pembelian sabun cuci piring Sunlight di Medan. Dan berdasarkan hipotesis yang ada, maka hasil dari penelitiain ini membuktikan bahwa hipotesis dapat diterima. Hal ini sesuai dengan penelitian terdahulu bahwa variabel-variabel yang tersebut berpengaruh secara signifikan. Sejalan dengan pernyataan Nicolino (2004) dimana nama merek memiliki peran-peran memotivasi orang untuk terlibat atau membeli, menjadikan produk mudah didapat, menciptakan titik fokus, menggambarkan hakikat atau fungsi produk dan menciptakan perasaan atau identifikasi positif. Hali ni juga akan menciptakanpersepsi terhadap kualitas sehingga kesadaran terhadap merek semakin kuat dan menghasilkan suatu keputusan konsumsi bagi konsumen.

Dari hasil tanggapan kosumen berdasarkan penelitian bahwa konsumen memutusan untuk membeli sabun pencuci piring Sunlight karena konsumen sudah percaya atas kualitas yang didapatkan dari produk tersebut sesuai keinginan. Dibandingkan dengan produk pesaing sejenis lainnya Sunlight adalah pembersih ampuh yang sesuai kebutuhan konsumen untuk membersihkan peralatan rumah tangga menjadi lebih mudah. Ketersediaan dan harga yang sesuai dengan kualitas memberikan kesan yang positif yang mempengaruhi persepsi konsumen. Karena persepsi kualitas terhadap suatu produk akan akan mempengruh keputusan konsumen terhadap pembelian suatu produk, meningkatkan kepercayaan dan loyalitas konsumen terhadap suatu produk. 

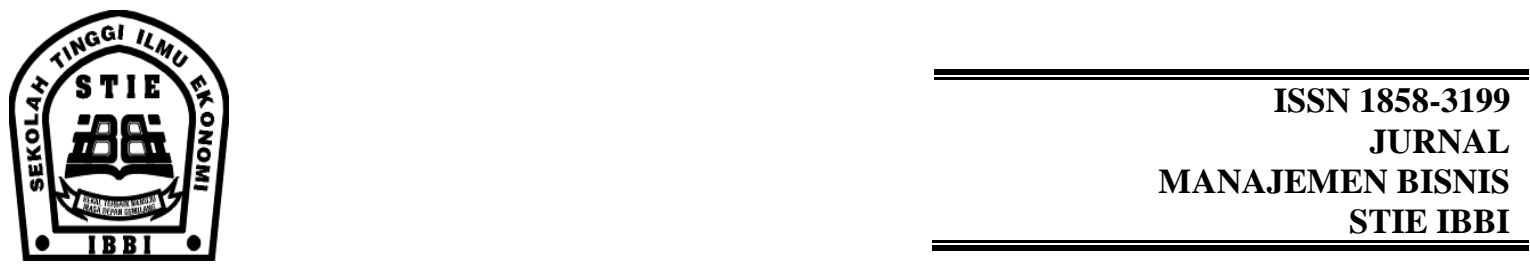

Sesuai dengan tanggapan responden atas pernyataan yang berkaitan dengan variabelvariabel penelitian menunjukkan bahwa pada dasarnya untuk variabel nama merek, responden dalam hal ini adalah konsumen setuju terhadap penempatan kata Sunlight sebagai nama merek yang dapat mewakili dari kualitas produk sabun pencuci piring cair sebagai pilihan dan layak direkomendasikan.

Sunlight sebagai sabun pencuci piring cair yang sudah familier bagi konsumen memberikan kesan yang berbeda dengan merek lain yang sejenis. Sehingga merek ini mampu memberikan kebutuhan sesuai dengan yang dijanjikan oleh produk tersebut. Konsumen tentunya juga akan rela melakukan pengorbanan atas kualias yang didapatkannya. Karena konsumen merasa bahwa untuk kualitas tertentu layak dibayar dengan jumlah tentu pula. Hal ini akan menjadi suatu citra merek yang terbentuk di benak konsumen terhadap produk tersebut.

Dari hasil uji secara parsial dapat dilihat bahwa variabel bebas yang terdiri dari nama merek, citra merek, persepsi kualitas dan brand awareness berengaruh secara positif dan signifikan terhadap kepputusan konsumen untuk membeli sabun pencuci piring cari Sunlight, sedangkan untuk variabel sikap konsumen tidak berpengaruh secara positif atau sikap konsumen negatif terhadap keputusan konsumen membeli produk tersebut. Hal ini bisa dikarenakan pengalaman dari para konsumen atau karen pengaruh orang lain. Terlebih dalam penelitian ini yang menjadi kendala dan hambatan adalah waktu dan kesedian para ibu rumah tangga untuk menjawab dan melakukanpengisian kuesioner esbagai instumen penelitian yang walaupun sudah dilakukan pengarahan dan penjelasan, tetapi mereka tidak mungkin untuk dipaksa. Hal ini seperti menurut Allport dalam Setiadi (2003), bahwa sikap adalah suat mental dan saraf sehubungan dengan kesiapan untuk menanggapi, diorganisasi melalui pengalaman dan memiliki pengaruh yang mengarahkan dan/atau dinamis terhadap perilaku. Dari pernyataan tersebut bahwa sikap adalah mempelajari kecenderungan memberrikan teanggapan terhadap suatu objek baik disenangi ataupun tidak disenangi secara konsisten. Dengan demikian konsumen melakukan evaluasi terhadap produk yang dikonsumsinya secara keseuruhan dari yang paling jelek sampai yang paling baik.

Konsumen yang suka atau bersikap positif terhadap suatu produk akan cenderung memiliki keinginan yang kuat untuk memilih dan membeli produk yang disukainya tersebut. Sebaliknya, kalau konsumen bersikap negatif terhadap suatu produk, maka biasanya akan tidak memperhitungkan produk tersebut sebagai pilihan pembelian, bahkan tidak jarang aka menyampaikan ketidaksukaannya tersebut kepada teman, kerabat dan tetanggganya (Suryani, 2008). Dengan demikian bagaimana agar pemasar untuk ke depannya mengembangkan sikap positif baik terhadap merek, terhadap produk maupun terhadap perusahaan. Sehingga produk tersebut bisa mempertahankan atau menjadi pemenang pasar.

Harga akan dapat mempengaruhi citra merek dari suatu produk, sejalan dengan Sciffman dan Kanuk (2004), harga dalam hal ini berkaitan dengan tinggi rendahnya atau banyak sedikitnya jumlah uang yang dikeluarkan oleh konsumen untuk mempengruhi suatu produk kjuga dapat mempengaruhui citra jangka panjang. Hal ini merupakan saah satu juga yang dapat mepengaruhi dari sikap konsumen utuk mengambil suatu keputusan. Terlebih banyaknya produk pesaing sejenis yang muncul mulai yang kualitasnya mendekati sabun pencuc piring Sunlight sampai kepada produk sabun pencuci piring cair lainnya yang tidak bermerek. Karena para ibu rumah tangga ada yang mempunyai sikap bahwa menyamakan semua produk sabun pencuci piring cair terlebih dari faktor harga karena menurut mereka pada dasarnya fungsinya adalah sama yaitu sama-sama berfungsi untuk membersihkan tanpa memperhatikan dan melihat nilai lainnya.

Terlebih para ibu rumah tangga yang sudah biasa dan mengenal Sunlight dengan baik, tidak akan terpengaruh secara nyata, dalam artian adakalanya mereka akan mencoba merek yang lain tapi 


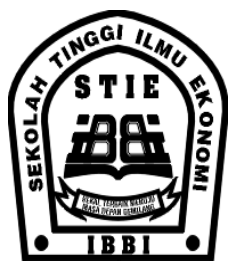

ISSN 1858-3199

JURNAL

MANAJEMEN BISNIS

STIE IBBI

setelahnya mereka akan kembali menggunakan produk yang sudah biasa mereka gunakan. Karena setiap ibu rumah tangga pasti menginginkan sesuatu yang lebih baik walau ada yang rela dengan sejumlah pengorbanan walaupun ada juga yang tidak.

Munculnya variasi produk pada merek yang sama juga akan mempengaruhi perilaku konsumen dalam hal keputusan pemilihan atau pembeiannya. Semakin banyak variasi produk akan menimbulkan ketidakpercayaan pada akhirnya dari konsumen. Karena dianggap produk tersebut tidak konsisten dengan kualitas dan produk yang telah dihasilkannya. Sementara pada konsumen sendiri ada fanatisme atau kesetiaan tersendiri terhadap satu varian produk pada merek yang sama dan tidak ingin mencoba yang lain. Karena kekhawatiran belum tentu memenuhi kebutuhan seperti yang sudah dialami selam menggunanakan produk tersebut.

\section{J. Kesimpulan dan Saran Kesimpulan}

Kesimpulan yang dihasilkan dari penelitian ini adalah:

a. Secara serempak bahwa varibel-variabel yang terdiri dari nama merek citra merek, persepsi kualitas, brand awareness dan sikap konsumen berpengaruh secara signifikan terhadap keputusan konsumen membeli sabun pencuci piring cair Sunlight. Dengan demikian hipotesis penelitian dapat diterima. Antara satu variabel penelitian dengan variabel penelitian lainnya dalam penelitian ini saling mempengaruhi, karena dengan satu variabel akan mengarah kepada munculnya variabel lain dalam perilaku konsumen.

b. Dari hasil uji secara parsial yang diperoleh bahwa nama merek, citra merek, persepsi kualitas dan brand awareness berpengaruh secara positif dan signifikan terhadap keputusan konsumen membeli sabun pencuci piring cair Sunlight, sedangkan untuk variabel sikap konsumen secara parsial tidak berpengaruh atau berpengaruh secara negatif. Dari hasil uji secara parsial juga dapat dilihat bahwa nama merek lebih berpengaruh daripada variabel lainnya.

\section{Saran}

a. Sunlight sebagai sabun pencuci piring cair yang sudah dikenal baik oleh masyarakat pada umumnya dan ibu rumah tangga khususnya untuk tetap menjaga agar sikap para konsumen positif terhadap produk ini. Dimana sikap tesebut secara akan berdampak terhadap perilakunya dan keputusannya, karena melalui sikap konsumen dapat diketahui suka tidaknya terhadap suatu produk tertentu.

b. Banyaknya varian produk yang ditawarkan dari sabun pencuci piring cair Sunlight membuat konsumen bisa menjadikan konsumen tidak setia, karena konsumen menganggap salah satu alas an dilakukan inovasi produk adalah karena dianggap produk sebelumnya memiliki kelemahan.

Sementara Sunlight sendiri sudah memiliki tempat di hati konsumen.

c. Kepada peneliti selanjutnya yang ingin melakukan penelitian dengan objek yang sama disarankan untuk lebih memfokuskan sample untuk mendapatkan data yang lebih teliti, kerena banyak hal yang dapat mempengaruhi persepsi konsumen terhadap menanggapi suatu hal, misal dari faktor demografi responden. 


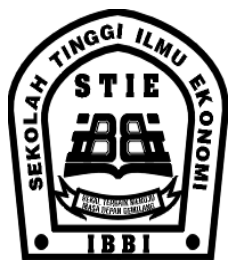

ISSN 1858-3199

JURNAL

MANAJEMEN BISNIS

STIE IBBI

\section{Daftar Pustaka}

Arikunto, Suharsimi. 2002, Prosedur Penelitian: Suatu Pendekatan Praktek, Jakarta: PT. Rineka Cipta.

Aritonang, R.Lerbin. 2007, Riset Pemasaran: Teori \& Praktik, Bogor: Ghalia Indonesia.

Berkowitz, Eric.N; Roger A. Kerin; Steven W. Hartley; dan William Rudelius. 2000. Marketing. $6^{\text {th }}$ Edition. Irwin: McGraw-Hill.

Boyd, W. Harper Jr., Orville C. Jr. Dan Jean-Claude Larreche. 2000. Manajemen Pemasaran: Suatu Pendekatan Strategis dengan Orientasi Global. Jakarta: Erlangga.

Engel, J.F. Blackwell, R.D., Miniard, PW.; Paul W.; Budiyanto, Fx. 2000. Perilaku Konsumen. Jakarta. Erlangga.

Ghozali, Imam. 2005. Aplikasi Ananlisis Multivariate dengan Program SPSS. Badan Penerbit UNDIP: Semarang

Hossain, Umar. 2007. Riset Pemasaran dan Perilaku Konsumen. Editor Sikumbang Risman F. Bogor: Ghalia Indonesia.

Kotler, Philip. 2005. Manajemen Pemasaran. Alih Bahasa. Benyamin Molan. Jilid Pertama. Jakarta. Indeks.

, dan A.B.Susanto. 2000. Manajemen Pemasaran di Indonesia. Buku Satu. Jakarta: Salemba Empat.

Lamb, Charles W; Joseph F. Hair; dan Carl McDaniel. 2001. Pemasaran. Alih Bahasa. David Octarevia. Edisi Pertama. Jilid Pertama. Jakarta: Salemba Empat.

Lamb, Charles W; Joseph F. Hair; dan Carl McDaniel. 2002. Marketing. Sixth Edition. Thomson: South Western.

Mowen, John.C dan Michael Minor. 2002. Perilaku Konsumen. Edisi Kelima. Jilid I, Jakarta: Erlangga

Nazir, 2005. Metode Penelitian. Bogor: Ghalia Indonesia.

Nicolino, Patricia F. 2007. The Complete Ideal's Guide: Brand Management. Sugiri. Jakarta. Pranada.

Payne, Adrian. 2000. The Essence of Service Marketing: Pemasaran Jasa. Trans. $\quad$ Fandy

Tjoptono. Yogyakarta: Andi.

Peter, J. Paul dan Jerry C. Olson. 2001. Consumer Behavior and Marketing Strategy. Sixt Edition. Irwin: McGraw-Hill.

Pratisto, Arif. 2004. Cara Mudah Mengatasi Masalah Statistik dan Rancangan Percobaan dengan SPSS 12 Jakarta: PT. Elex Media Komputindo.

Schiffman, Leon dan Leslie Lazar Kanuk. 2007. Perilaku Konsumen. Alih Bahasa. Jakarta. Indeks.

Simamora, Henry. 2003. Manajemen Pemasaran Internasional. Jakarta: PT. Rineka Cipta

Sugiyono, 2006. Metode Penelitian Bisnis. Bandung: CV Alfabeta.

Sunarto. 2004. Prinsip-prinsip Pemasaran. Yogyakarta: AMUS

Sumarwan, Ujang. 2002. Perilaku Konsumen: Teori dan Penerapannya dalam Pemasaran. Bogor: Ghalia Indonesia.

Supranto, J dan Nandan Limakrisna. 2007. Perilaku Konsumen dan Strategi Pemasaran Untuk Memenangkan Persaingan Bisnis. Jakarta. Mitra Wacana Media.

Suryani, Tatik. 2008. Perilaku Konsumen. Implikasi Pada Strategi Pemasaran. Yogyakarta. Graha Ilmu

Setiadi, J Nugroho. 2003. Perilaku Konsumen: Konsep dan Implikasi untuk Strategi dan Penelitian Pemasaran. Jakarta: Prenada Media. 


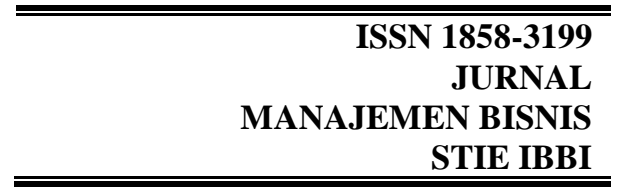

Tjiptono, Fandy. 2002. Strategi Pemasaran. Yogyakarta: Andi.

2005. Brand Management \& Strategy. Yogyakarta. Andi.

Umar, Husein. 2000. Riset Pemasaran \& Perilaku Konsumen. Jakarta: PT. Gramedia Pustaka Utama.

\section{BUKAN BUKU}

Mayasari, Lusi Indah. 2011. Analisis Pengaruh Citra Merek, Persepsi Terhadap Kualitas, Nama Merek, Brand Awareenes Terhadap Keeputusan Pembelian Sabun Pencuci Pakaian Bubuk. Semarang: Fakultas Ekonomi: Universitas Diponegoro. 


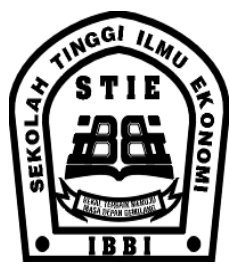

ISSN 1858-3199

JURNAL

MANAJEMEN BISNIS

STIE IBBI

\title{
Pengaruh Kepemimpinan, Motivasi Kerja, Dan Budaya Organisasi Pegawai Di Satuan Kerja Perangkat Daerah (SKPD) Kota Medan Terhadap Kepuasan Masyarakat
}

\author{
Maretta Ginting, SE., M.Si \\ Dewi Shinta Wulandari Lubis, BSc, Soc, MHRM \\ Dosen Tetap STIE IBBI Medan
}

Pelayanan pemerintah terhadap masyarakat menjadi suatu hal yang semakin hari menjadi perhatian dan menjadi titik sentral evaluasi efektifitas pemerintahan. Dalam rangka mencapai hal tersebut dibutuhkan pegawai pemerintahan negara yang memiliki kinerja yang baik agar seluruh fungsi fungsi pemerintahan dapat berjalan dengan baik. Setiap pegawai pemerintahan harus mampu menjalankan tugas pokok dan fungsinya sesuai dengan yang telah ditetapkan. Dalam rangka menjalankan tugas pokok dan fungsi tersebut, pegawai pemerintahanur negara dipengaruhi oleh berbagai faktor. Diantara berbagai faktor yang penting tersebut diidentifikasi beberapa faktor seperti kepemimpinan, motivasi kerja, dan budaya organisasi. Kepemimpinan mengacu pada efektifitas pemimpin mengorganisir dan mengelola staf yang dimiliki. Motivasi kerja mengacu pada bagaimana faktor dorongan dari dalam diri pegawai pemerintahanur negara untuk bekerja dengan baik. Motivasi tersebut dapat bersumber dari berbagai hal. Budaya organisasi merupakan kebiasaan dan pola umum yang mempengaruhi organisasi pemerintahan. Sebagaimana biasanya kinerja pemerintahan di beberapa tempat yang sering mendapatkan kritikan karena layanan yang diberikan jauh dari memuaskan, layanan pegawai pemerintahanur di Kota Medan dalam berbagai kesempatan juga dikatakan kurang optimal. Banyak masyarakat tidak puas dan sering terdapat berbagai keluhan. Menyikapi hal tersebut, peneliti sangat tertarik untuk memahami faktor-faktor diduga mempengaruhi kinerja layanan pegawai pemerintahanur pemerintahan. Penelitian ini melakukan survey atas hal tersebut dengan memilih 180 pegawai pemerintahan negara dari 18 Satuan Kerja Perangkat Daerah (SKPD). Sebagai pengukur tingkat kepuasan dipilih 180 masyarakat yang memperoleh layanan dari 18 SKPD yang bersangkutan. Dari hasi penelitia didapatkan bahwa kepemimpinan, motivasi kerja dan budaya organisasi secara simultan memiliki pengaruh terhadap kinerja pegawai pemerintahan di lingkungan Pemerintahan Kota Medan. Sedangkan secara parsial didapatkan bahwa hanya kepemimpinan yang mampu mempengaruhi kinerja pegawai SKPD sehingga meningkatkan kepuasan masyarakat. 


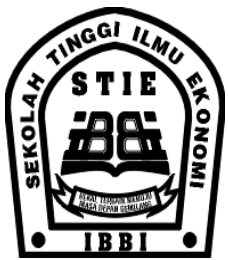

ISSN 1858-3199

JURNAL

MANAJEMEN BISNIS

STIE IBBI

\section{PENDAHULUAN}

\section{Latar Belakang}

Pada masa keterbukaan seperti yang ada saat ini, kinerja pemerintahan dituntut untuk lebih baik bahkan tidak jarang dituntut untuk menyamai kinerja di perusahaan swasta. Dalam rangka menanggapi tuntutan tersebut pemerintah dituntut untuk bekerja semakin profesional agar masyarakat yang menjadi pihak yang dilayani dapat merasakan suatu layanan yang prima. Era keterbukaan tersebut membuat masyarakat semakin berani menyampaikan kritikan secara terbuka. Hal ini mendorong semua satuan pemerintahan tidak mempunyai pilihan lain kecuali berubah menurut tuntutan masyarakat. Pada sisi lain pelaksanaan otonomi daerah membuat pusat pertanggungjawaban menjadi cukup jelas dan tidak memiliki rantai birokrrasi yang panjang. Hal ini berarti baik dan buruknya pelayanan suatu pemerintahan daerah otonom sangat dipengaruhi dan dipertanggungjawabkan pemimpin daerah otonom masing-masing baik kabupaten maupun kota. Dalam rangka hal tersebut maka pemimpin daerah otonom harus mampu mendorong layanan yang baik karena masyarakat akan segera mentut perbaikan langsung kepada pemimpin tersebut jika terdapat berbagai masalah di masyarakat. Oleh karena hal tersebut, pemimpin harus mampu mengorganisir seluruh pegawai pemerintahan yang berada dalam pengendaliannya untuk memberikan layanan yang baik bagi masyarakat.

Isu kepuasan masyarakat terhadap pemerintahan merupakan isu yang sangat sering dibicarakan dalam dinamika aktivitas manajemen pemerintahan. Hal ini dapat dilihat dari banyaknya pembentukan pelatihan-pelatihan maupun pendidikan kilat yang diadakan di lingkungan pemerintahan untuk meningkatkan kemampuan layanan setiap aparat pemerintahan. Pelaksanaan pelatihan dan pendidikan tersebut tentunya bersumber dari kesadaran akan perlunya pegawai pemerintahan yang memiliki kemampuan dan berbagai faktor lain yang dibutuhkan dalam menunjang pemberian layanan yang baik bagi masyarakat. Kepuasan layanan yang dirasakan masyarakat sangat tergantung pada seberapa besar kontribusi yang diberikan oleh pegawai pemerintahan didalam setiap aktivitas pekerjaannya. Setiap pegawai pemerintahanharusnya ingin menunjukkan prestasinya yang maksimal untuk dapat memberikan layanan terbaik bagi masyarakat. Prestasi kerja yang baik dianggap akan dapat menghasilkan pengelolaan pemerintahan yang efektif dan efisien dan memberikan kepuasan bagi masyarakat. Prestasi kerja pegawai pemerintahan ini baru dapat dinilai dengan baik jika masyarakat yang menjadi sasaran pelayanan memberikan apresiasi positif terhadap pelayanan yang diberikan oleh suatu satuan kerja. Pemenuhan prestasi kerja pegawai pemerintahan yang maksimal dipengaruhi oleh banyak faktor psikologis. Faktor psikologis sangat berperan pada pencapaian prestasi pegawai pemerintahan karena menyangkut kepribadian pegawai pemerintahan. Faktor psikologis yang mempengaruhi pegawai pemerintahan dapat berasal dari dalam ataupun dari luar diri pegawai pemerintahan.Baik pengaruh dari dalam maupun pengaruh dari luar sangat penting untuk mengendalikannya didalam diri seorang pegawai pemerintahan untuk memberikan kepuasan kerja yang tinggi didalam mencapai prestasi kerjanya didalam pemerintahan.

Kinerja sebuah pemerintahan sangat tidak terlepas dari faktor kepemimpinan dari pemimpin didalam pemerintahan. Hal inilah yang membuat anggapan bahwa faktor kepemimpinan yang paling menentukankeberhasilan suatu satuan kerja. Sosok pemimpin didalam memberikan dorongan moral kepada pegawai merupakan hal yang harus selalu dipenuhi. Tanpa keberadaan seorang pemimpin, setiap pegawai pemerintahanakan beraktivitas tanpa adanya teladan sebagai acuan pencapaian tujuan kerjanya. Pemimpin akan berfungsi sebagai stimulus bagi pegawai pemerintahan dalam mencapai tujuan yang ingin dicapai pemerintahan lewat pegawai pemerintahannya. Hal ini 


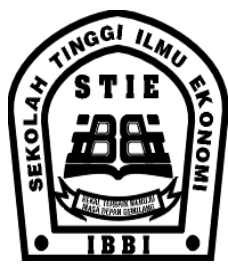

ISSN 1858-3199

JURNAL

MANAJEMEN BISNIS

STIE IBBI

dapat terlihat dari fenomena di beberapa pemerintahan otonom yang memiliki pemimpin yang mampu memberikan teladan menjadikan pegawai pemerintahan di bawahnya dapat bekerja dengan baik. Hal ini mulai dapat terlihat dari pemerinthan DKI Jakarta dimana faktor pemimpin secara nyata telah menjadi unsur pendorong yang kuat dalam menggerakkkan birokrasi pemerintahan.

Selain faktor kepemimpinan, pengembangan motivasi diri dari pegawai pemerintahan adalah hal yang tidak bisa untuk dilepaskan dalam pemberian layanan kepada msayarakat. Kepemimpinan yang sangat berpengaruh didalam pemerintahan tidak akan dapat memberikan dorongan bagi pegawai pemerintahan, tanpa adanya motivasi dalam diri pegawai pemerintahan untuk mencapai apa yang ingin dicapai oleh satuan kerjanya. Suatu satuan kerja yang memiliki pegawai yang tidak mempunya motivasi untuk mencapai tujuan atau standar layanan di unit kerjanya akan relatif membuat satuan kerja tersebut tidak mampu bekerja dengan optimal.

Kepuasan masyarakat atas layanan yang diberikan satuan kerja juga juga tidak terlepas dari bagaimana budaya didalam organisasi pemerintahantersebut. Budaya tentunya dibentuk oleh interaksi yang terintegrasi dalam suatu satuan kerja. Budaya organisasi yang kondusif dianggap akan dapat memicu keinginan pegawai pemerintahan dalam mencapai layanan prima bagi masyarakat. Pembentkan budaya yang cenderung tidak menunjukkan suatu viri khas yang kuat relatif akan membuat perusahaan tidak memilki suatu hasrat atau niatan yang kuat untuk memberikan suatu layanan yang baik.

Berbagai hal yang dijelaskan diatas terjadi pada semua daerah otonom di Indonesia termasuk Kota Medan. Kota Medan termasuk kota besar di Indonesia dituntut untuk memberikan layanan yang baik bagi masyarakat kota Medan. Dalam rangka mencapai hal tersebut walikota diberikan seperangkat satuan kerja beserta aparat untuk melaksanakan tugas pemerintahan. Sejalan dengan penjelasan yang telah disampaikan diatas, peneliti tertarik untuk melihat kaitan dan pengaruh antara berbagai faktor di dalam diri individual pegawai pemerintahan terkait motivasi, budaya dan kepemimpinan dan dampaknya terhadap kepuasan masyarakat yang dilayani oleh satuan kerja tersebut. Berdasarkan hal tersebut peneliti tertarik melaksanakan suatu penelitian berjudul "Pengaruh Kepemimpinan, Motivasi Kerja, dan Budaya Organisasi Pegawai di Satuan Kerja Perangkat Daerah (SKPD) Kota Medan Terhadap Kepuasan Masyarakat”

\section{Perumusan Masalah}

Berdasarkan latar belakang yang telah disampaikan diatas, maka peneliti telah menentukan perumusan masalah penelitian ini sebagai berikut: "Apakah Kepemimpinan, Motivasi Kerja, dan Budaya Organisasi Pegawai di Satuan Kerja Perangkat Daerah (SKPD) di Kota Medan memberikan pengaruh kepada Kepuasan Masyarakat?"

\section{Kerangka Konseptual dan Hipotesa}

Setiap satuan kerja seharusnya mengarahkan seluruh sumber daya yang dimiliki untuk menjalankan tugas pokok dan fungsi yang diembankan kepada masing-masing satuan kerja. Dalam rangka mencapai hal tersebut terdapat berbagai faktor yang harus dipenuhi agar pegawai pemerintahan bersedia memberikan segala kemampuan terbaik dalam melayani masyarakat.

Kepemimpinan yang memiliki pengaruh didalam pemerintahan dianggap akan mampu memberikan dorongan bagi pegawai pemerintahan untuk memberikan usaha terbaik dalam pencapaian tujuan kerja. Kemampuan pemimpin dalam menyatukan setiap aktivitas kerja secara terintegrasi dianggap akan memberikan kontribusi positif dalam pencapaian tujuan kerja. Teori 


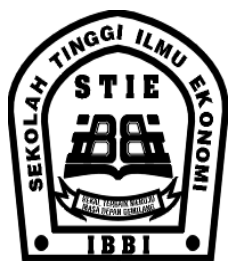

ISSN 1858-3199

JURNAL

MANAJEMEN BISNIS

STIE IBBI

kepemimpinan saat ini menyatakan bahwa kemampuan memberikan dorongan dan dukungan yang diperlukan akan membuat aparat pemerintahan bersedia dan mampu mengerjaan sesuatu dengan baik, benar dan optimal. Berdasarkan hal ini dapat dikatakan bahwa semakin baik peran pemimpin dalam suatu satuan kerja maka akan semakin besar kemungkinan pegawai pemerintahan yang dikoordinir bekerja dengan baik.

Faktor internal pegawai pemerintahan seperti motivasi diri juga merupakan hal yang tidak dapat dilepaskan dari layanan yang mereka berikan pda masyarakat. Dorongan dari dalam diri pegawai pemerintahan dianggap sangat signifikan memberikan pengaruh terhadap keinginan bekerja dengan baik. Motivasi dapat bersumber dari berbagai hal seperti idealisme, jenjang karir, reward upah, penghargaan komunitas dan berbagai sumber motivasi lainnya. Sesorang pegawai pemerintahan yang mmiliki motivasi yang tinggi akan memilki cara kerja yang jauh berbeda dengan aparat pemerintahan yang motivasinya sangat rendah.

Budaya organisasi sebagai suatu faktor yang memberikan pengaruh yang didapatkan oleh pegawai pemerintahan dalam organisasi satuan kerja tersebut. Hal ini mengacu pada kebiasaan ataupun nilai-nilai yang dipegang di dalam satu satuan kerja yang mengilhami dan mendasari cara bertindak dari orang-orang yang ada di dalam organisasi tersebut. Budaya organisasi akan membentuk bagaimana pegawai pemerintahan memandang aktivitas kerjanya. Budaya yang baik yang berorientasi pada kepuasan layanan masyarakat tentunya akan berbeda dengan budaya kerja di suatu organisasi yang berfokus pada tertib administrasi saja. Budaya organisasi yang kuat dalam pecapaian tujuan pemerintahan dianggap akan mampu memberikan dorongan yang kuat bagi pemberian laanan prima bagi masyarakat.

Kepuasan masyarakat dipandang sebagai pengukur yang lebih fair atas kinerja pegawai pemerintah. Jika masyarakat yang mmperoleh layanan dari suatu instansi tertentu memperoleh kepuasan maka dapat dikatkan instansi tersebut telah memberikan layanan yang baik sesuai dengan tugas pokok dan fungsinya. Berdasarkan hal tersebut akan dipilih secara acak masyarakat yang memperoleh layanan dari suatu instansi dan diminta untuk memberikan penilaian kepuasan atas layanan yang telah mereka terima. Berdasarkan teori dan kerangka konseptual yang telah dikemukakan, maka hipotesis dari penelitian ini adalah: Kepemimpinan, Motivasi Kerja, dan Budaya Organisasi Pegawai di Satuan Kerja Perangkat Daerah (SKPD) di Kota Medan memberikan pengaruh positif kepada Kepuasan Masyarakat

\section{TINJAUAN KEPUSTAKAAN}

\section{Kepuasan Masyarakat}

Terdapat banyak pandangan tentang kepuasan masyarakat atas pelayanan publik. Banyak acuan dan standard yang telah dibuat untuk mengukur hal tersebut. Konsep kepuasan masyarakat terhadap layanan publik banyak mengacu pada teori yang berkembang di dalam perusahaan yang memandang masyarakat yang dilayani sebagai pelanggan. Menteri Negara Pendayagunaan Aparatur Negara (MENPAN) dalam keputusannya Nomor : 81/1995 menegaskan bahwa pelayanan yang berkualitas hendaknya sesuai dengan sendi-sendi sebagai berikut : (1) Kesederhanaan, (2) Kejelasan dan kepastian, (3) Keamanan, (4) Keterbukaan, (5) Efisien, (6) Ekonomis, (7) Keadilan yang merata (8) Ketepapatan waktu.

\section{Kepemimpinan}

Kepemimpinan dapat diartikan sebagai proses mempengaruhi dan mengarahkan para pegawai dalam melakukan pekerjaan yang telah ditugaskan kepada mereka. Mariam (2009) 


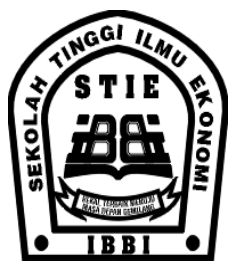

ISSN 1858-3199

JURNAL

MANAJEMEN BISNIS

STIE IBBI

menyatakan bahwa kepemimpinan dapat dipahami sebagai kemampuan mempengaruhi bawahan agar terbentuk kerjasama di dalam kelompok untuk mencapai tujuan organisasi. Kepemimpinan adalah proses dalam mengarahkan dan mempengaruhi para anggota dalam hal berbagai aktivitas yang harus dilakukan. Adapun dari sisi atribut, kepemimpinan adalah kumpulan karakteristik yang harus dimiliki oleh seorang pemimpin. Oleh karena itu, pemimpin dapat didefinisikan sebagai seorang yang memiliki kemampuan untuk mempengaruhi perilaku orang lain tanpa menggunakan kekuatan, sehingga orang-orang yang dipimpinnya menerima dirinya sebagai sosok yang layak memimpin mereka.

\section{Motivasi Kerja}

Robbins dan Judge (2007) mendefinisikan motivasi sebagai proses yang menjelaskan intensitas, arah dan ketekunan usaha untuk mencapai suatu tujuan. Aribowo (2011) mengemukaan bahwa motivasi berasal dari bahasa latin, yakni Movere yang berarti "menggerakkan" (to move).Dengan pengertian, bahwa tercapainya tujuan organisasi berarti tercapai pula tujuan pribadi para anggota organisasi yang bersangkutan.Yetiskin (2009) menyatakan bahwa pengertian dari motivasi intrinsikadalah untuk menggambarkan tendensi individual-individual untuk terlibat ke dalam aktivitas yang menarik, melampaui tingkatan yang baik, kesenangan dan proses mempengaruhi atau mendorong dari luar terhadap seseorang atau kelompok kerja agar mereka mau melaksanakan sesuatu yang telah ditetapkan. Sedangkan motivasi secara ekstrinsik menjelaskan tendensi atas pandangan faktor-faktor seperti hadiah, hukuman dan kompetisi (Ryan dan Deci, dalam Yetiskin,2009). Maka dapat kita ketahui bahwa motivasi akan mempengaruhi seseorang untuk melakukan suatu pekerjaan.

\section{Budaya Organisasi}

Dalam kehidupan masyarakat sehari-hari tidak terlepas dari ikatan budaya yang diciptakan. Ikatan budaya tercipta oleh masyarakat yang bersangkutan, baik dalam keluarga, organisasi, bisnis maupun bangsa. Budaya membedakan masyarakat satu dengan yang lain dalam cara berinteraksi dan bertindak menyelesaikan suatu pekerjaan. Budaya mengikat anggota kelompok masyarakat menjadi satu kesatuan pandangan yang menciptakan keseragaman berperilaku atau bertindak. Seiring dengan bergulirnya waktu, budaya pasti terbentuk dalam organisasi dan dapat pula dirasakan manfaatnya dalam memberi kontribusi bagi efektivitas organisasi secara keseluruhan. Jocano dalam Sobirin (2007:152-153) menyatakan bahwa budaya organisasi terdiri dari unsur utama, yakni yang bersifat idealistik dan yang bersifat perilaku atau behavioral. Unsur budaya organisasi idealistik merupakan ideologi organisasi yang tidak mudah berubah meskipun di sisi lain organisasi harus berubah untuk beradaptasi dengan lingkungannya. Ideologi ini bersifat terselubung, tidak nampak di permukaan dan hanya orang-orang tertentu saja yang tahu apa sesungguhnya ideologi mereka dan mengapa organisasi tersebut didirikan.

\section{TUJUAN DAN MANFAAT PENELITIAN}

Penelitian yang sudah dilaksanakan ini bertujuan untuk menganalisis berbagai faktor yang menentukan kepuasan masyarakat atas layanan yang diberikan Satuan Kerja Perangkat Daerah (SKPD) di lingkungan Pemerintahan Kota Medan. Analisis tersebut diperlukan agar dapat diformulasikan berbagai strategi untuk meningkatkan kepuasan masyarakat. Kepuasan masyarakat menjadi sesuatu yang sangat penting bagi suatu pemerintahan karena menjadi ukuran kinerja yang 


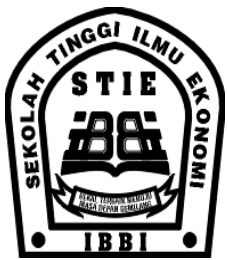

ISSN 1858-3199

JURNAL

MANAJEMEN BISNIS

STIE IBBI

paling valid. Hal ini dikarenakan kepuasan masyarakat menjadi salah satu tujuan terpenting bagi pemerintahan.

Penelitian ini mengidentifikasi tiga faktor terpenting dalam menentukan kualitas layanan suatu SKPD adalah Budaya Organisasi yang terbentuk di dalam suatu kantor. Budaya ini secara teroritis akan menentukan bagaimana setiap individu di dalam organisasi tersebut bekerja dan memberikan layanan. Variabel kedua yang diduga memiliki pengaruh yang signifikan adalah motivasi kerja dari staf yang ada di dalam suatu SKPD. Secara rasional dapat dipahami bahwa seseorang akan memiliki kinerja yang baik jika didorong motivasi kerja yang inggi demikian sebaliknya. Hal ini membuat motivasi diduga akan menjadi suatu unsur penetu kinerja yang penting. Variabel ketiga yang diduga akan mempengaruhi kualitas layanan pada masyarakat adalah kepemimpinan di dalam organisasi tersebut. Kepemimpinan akan ememiliki signifikansi dalam pengelolaan layanan yang diberikan.

Manfaat penelitian ini adalah untuk memberikan rekomendasi perbaikan dan/atau peningkatan atas pelayanan publik yang diberikan di SKPD di Kota Medan. Hal ini sangat penting dilakukan untuk memberikan sumbangan atas perbaikan layanan masyarakat yang dilaksanakan oleh suatu SKPD. Rekomendasi tersebut akan dapat diberikan setelah melakukan analisis terhadap hasil-hasil yang diperoleh dari pengolahan data yang diperoleh. Data-data tersebut akan diolah secara statistic sebelum dilakukan analisis terhadap output hasil data statistik tersebut.

\section{METODE PENELITIAN}

Jenis penelitian yang dilakukan adalah penelitian asosiatif kausal yaitu penelitian yang bertujuan untuk mengetahui hubungan yang bersifat sebab akibat. Objek dari Penelitian ini adalah pegawai dari SKPD yang ada di lingkungan Pemerintah Kota Medan. Penelitian ini menggunkan instrumen kuesioner untuk mendapatkan data yang mendukung penelitian ini. Tabel 1 merupakan rangkuman dari pembentukan variabel dari penelitian ini.

Tabel 1. Defenisi Operasional Variabel

\begin{tabular}{|c|c|c|c|}
\hline $\begin{array}{c}\text { Variabel } \\
\text { Penelitian }\end{array}$ & Definisi Operasional & Pengukuran Variabel & $\begin{array}{c}\text { Skala } \\
\text { Pengukuran }\end{array}$ \\
\hline $\begin{array}{l}\text { Kepemimpinan } \\
(\mathrm{KP})\end{array}$ & $\begin{array}{l}\text { Merupakan suatu kegiatan mengarahkan } \\
\text { dan mempengaruhi orang lain untuk } \\
\text { dapat mengerjakan sesuatu sesuai } \\
\text { dengan apa yang telah direncanakan. }\end{array}$ & $\begin{array}{l}\text { - } \quad \text { Kepemimpinan yang } \\
\text { berorientasi pada orang } \\
\text { - } \quad \text { Kepemimpinan yang } \\
\text { berorientasi pada tugas }\end{array}$ & Ordinal \\
\hline $\begin{array}{l}\text { Motivasi Kerja } \\
(\mathrm{MK})\end{array}$ & $\begin{array}{l}\text { Merupakan dorongan yang berasal dari } \\
\text { dalam ataupun dari luar diri pegawai } \\
\text { pemerintahan untuk dapat memenuhi } \\
\text { dan mencapai tujuan dari pemerintahan. }\end{array}$ & $\begin{array}{ll}\text { - } & \text { Prestasi Kerja } \\
\text { - } & \text { Pengaruh } \\
\text { - } & \text { Pengendalian } \\
\text { - } & \text { Ketergantungan } \\
\text { - } & \text { Perluasan } \\
\text { - } & \text { Afiliasi }\end{array}$ & Ordinal \\
\hline $\begin{array}{l}\text { Budaya } \\
\text { Organisasi (BO) }\end{array}$ & $\begin{array}{l}\text { Merupakan suatu nilai atau pandangan } \\
\text { tentang bagaimana suatu aktivitas } \\
\text { pekerjaan dilakukan dan dicapai } \\
\text { tujuannya. }\end{array}$ & $\begin{array}{ll}\text { - } & \text { Profesionalsime } \\
\text { - } & \text { Jarak dari Manajemen } \\
\text { - } & \text { Percaya pada Rekan } \\
& \text { Sekerja } \\
\text { - } & \text { Keteraturan } \\
\text { - } & \text { Permusuhan }\end{array}$ & Ordinal \\
\hline
\end{tabular}




\begin{tabular}{|c|c|c|c|}
\hline & & - Integrasi & \\
\hline Kepuasan (KPL) & $\begin{array}{l}\text { Tingkat kepuasan yang diperoleh } \\
\text { konsumen dalam layanan publik yang } \\
\text { dia teruma }\end{array}$ & $\begin{array}{ll}\text { - } & \text { Kesederhanaan } \\
\text { - } & \text { Kejelasan } \\
\text { - } & \text { Keamanan } \\
\text { - } & \text { Keterbukaan } \\
\text { - } & \text { Efisien } \\
\text { - } & \text { Ekonomis } \\
\text { - } & \text { Keadilan } \\
\text { - } & \text { Ketepatan waktu }\end{array}$ & Ordinal \\
\hline
\end{tabular}

Pengujian yang dilakukan dalam penelitian ini adalah pengujian validitas data, asumsi klasik, dan pengujian hipotesis dari penelitian ini.

\section{HASIL DAN PEMBAHASAN}

Jumlah kuesioner yang disebar kepada responden sebanyak 180 kuesioner dan dilakukan satu tahap. 180 responden merupakan pegawai dan masyarakat pengguna layanan jasa dari 18 SKPD di Kota Medan. Dari 180 kuisioner yang dibagikan, dikarenakan mekanisme penyebaran kuesioner secara langsung dan selesai saat penyebaran, maka yang kembali adalah seluruhnya sebanyak 180 kuesioner. Berikut ini merupakan daftar objek instansi yang menjadi sasaran penyebaran kuesioner penelitian ini:

Pengujian instumen yang digunakan dalam penelitian ini adalah uji validitas dan uji realibilitas. Alat ukur yang dapat digunakan dalam pengujian validitas suatu kuesioner adalah angka hasil korelasi antara skor pernyataan dan skor keseluruhan pernyataan responden terhadap informasi dalam kuesioner melalu metode pearson correlation. Asumsi yang digunakan dalam uji validitas adalah jika $r_{\text {hitung }}$ lebih besar dari $r_{\text {tabel }}\left(r_{\text {hitung }}>r_{\text {tabel }}\right)$, maka item pernyataan tersebut dinyatakan valid.

Berdasarkan pada tabel 3 terlihat bahwa hasil uji validitas menunjukkan semua pertanyaan valid karena $r_{\text {hitung }}>r_{\text {tabel }}$ pada taraf signifikansi 5\%. Berdasarkan hasil ini maka semua item pernyataan untuk keseluruhan variabel dapat dinyatakan valid.

Tabel 2. Hasil Uji Validitas Kuesioner Penelitian

\begin{tabular}{|l|c|c|c|c|c|}
\hline \multicolumn{2}{|c|}{ Variabel Budaya Organisasi (BO) } & \multicolumn{3}{c|}{ Variabel Motivasi Kerja (MK) } \\
\hline \multicolumn{1}{|c|}{ Item } & CITC & Ket & Item & CITC & Ket \\
\hline Item 1 & .902 & Valid & Item 1 & .881 & Valid \\
\hline Item 2 & .851 & Valid & Item 2 & .829 & Valid \\
\hline Item 3 & .849 & Valid & Item 3 & .869 & Valid \\
\hline Item 4 & .812 & Valid & Item 4 & .832 & Valid \\
\hline Item 5 & .850 & Valid & Item 5 & .792 & Valid \\
\hline Item 6 & .849 & Valid & Item 6 & .844 & Valid \\
\hline Item 7 & .864 & Valid & Item 7 & .783 & Valid \\
\hline Item 8 & .810 & Valid & Item 8 & .796 & Valid \\
\hline Item 9 & .827 & Valid & Item 9 & .766 & Valid \\
\hline Item 10 & .844 & Valid & Item 10 & .774 & Valid \\
\hline Item 11 & .820 & Valid & Item 11 & .801 & Valid \\
\hline Item 12 & .813 & Valid & Item 12 & .769 & Valid \\
\hline Item 13 & .792 & Valid & Item 13 & .745 & Valid \\
\hline Item 14 & .842 & Valid & Item 14 & & Valid \\
\hline
\end{tabular}




\begin{tabular}{|c|c|c|c|c|c|}
\hline Item 15 & .823 & Valid & Item 15 & .744 & Valid \\
\hline Item 16 & .789 & Valid & Item 16 & .798 & Valid \\
\hline Item 17 & .832 & Valid & Item 17 & .779 & Valid \\
\hline Item 18 & .827 & Valid & Item 18 & .722 & Valid \\
\hline Item 19 & .812 & Valid & Item 19 & .761 & Valid \\
\hline Item 20 & .832 & Valid & Item 20 & .825 & Valid \\
\hline Item 21 & .817 & Valid & Item 21 & .728 & Valid \\
\hline Item 22 & .834 & Valid & Item 22 & .744 & Valid \\
\hline Item 23 & .840 & Valid & Item 23 & .805 & Valid \\
\hline Item 24 & .807 & Valid & Item 24 & .830 & Valid \\
\hline Item 25 & .799 & Valid & Item 25 & .846 & Valid \\
\hline Item 26 & .849 & Valid & Item 26 & .740 & Valid \\
\hline Item 27 & .763 & Valid & Item 27 & .791 & Valid \\
\hline Item 28 & .777 & Valid & Item 28 & .842 & Valid \\
\hline Item 29 & .836 & Valid & Item 29 & .767 & Valid \\
\hline Item 30 & .818 & Valid & Item 30 & .917 & Valid \\
\hline Item 31 & .832 & Valid & \multicolumn{3}{|c|}{ Variabel Kepemimpinan (K) } \\
\hline Item 32 & .790 & Valid & Item & CITC & Ket \\
\hline Item 33 & .853 & Valid & Item 1 & .892 & Valid \\
\hline Item 34 & .863 & Valid & Item 2 & .841 & Valid \\
\hline Item 35 & .872 & Valid & Item 3 & .865 & Valid \\
\hline Item 36 & .858 & Valid & Item 4 & .864 & Valid \\
\hline Item 37 & .841 & Valid & Item 5 & .892 & Valid \\
\hline Item 38 & .861 & Valid & Item 6 & .866 & Valid \\
\hline Item 39 & .859 & Valid & & & \\
\hline Item 40 & .823 & Valid & & & \\
\hline Item 41 & .907 & Valid & & & \\
\hline Item 42 & .892 & Valid & & & \\
\hline Item 43 & .860 & Valid & & & \\
\hline
\end{tabular}

Sumber : Data olahan SPSS

Hasil pengujian terhadap reabilitas kuesioner ditunjukkan pada tabel berikut. Hasil tersebut menunjukkan bahwa seluruh kuesioner dapat digolongkan reliabel dan dapat digunakan untuk mengukur variabel yang sedang diteliti.

Tabel 3. Hasil Uji RealibilitasKuesioner Penelitian

\begin{tabular}{|c|c|}
\hline Variabel & Cronbach's Alpha \\
\hline Budaya Organisasi (BO) & 0.990 \\
Motivasi Kerja (MK) & 0.982 \\
Kepemimpinan (K) & 0.959 \\
\hline
\end{tabular}

Sumber : Data olahan SPSS

Pengujian statistik dengan analisis regresi dapat dilakukan dengan pertimbangan tidak adanya pelanggaran terhadap asumsi-asumsi klasik. Asumsi - asumsi klasik tersebut antara lain. Menurut Ghozali (2007) Uji Normalitas bertujuan untuk mengetahui apakah distribusi sebuah data 
mengikuti atau mendekati distribusi normal, yaitu distribusi data dengan bentuk lonceng (bell Shaped). Residual dari model harus berdistribusi normal, hal ini dapat diketahui dengan menggunakan kurva Normal P-Plot. Berdasarkan gambar dibawah ini dapat disimpulkan bahwa residual model berdistribusi normal sehingga dapat disimpulkan model ini dapat digunakan dalam penarikan kesimpulan atas hipotesa.

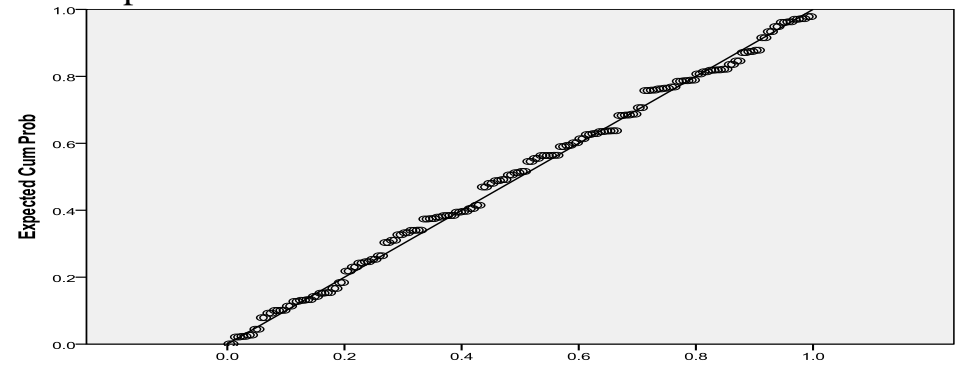

Gambar 1. PP Plot

Gejala heteroskedastisitas timbul karena adanya ketidak-konstanan variansi error sehingga hasil regresi menjadi diragukan karena estimator yang digunakan menjadi tidak efisien. Pengujian heteroskedastisitas dapat dilakukan dengan membentuk diagram plot untuk melihat pola persebaran data. Apabila pola persebaran data tidak membentuk pola tertentu maka data dapat dikatakan terbebas dari hetroskedastisitas. Berdasarkan gambar dibawah ini, dapat disimpulkan bahwa data di dalam penelitian ini terbebas dari gejala heteroskedastisitas.

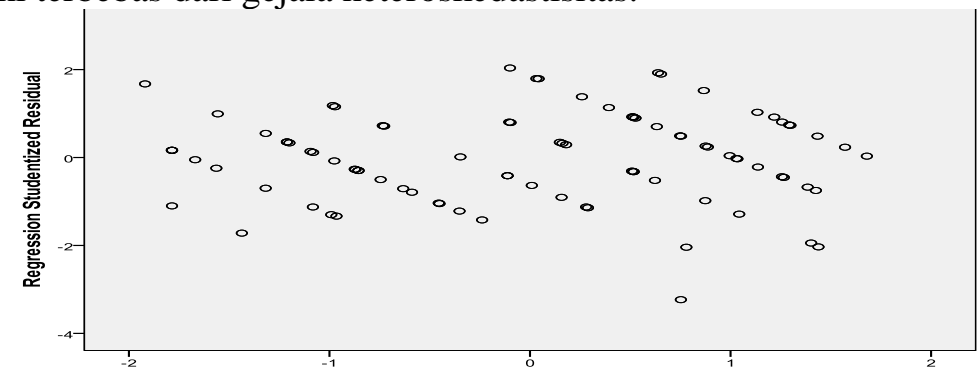

Gambar 2. Pengujian Heteroskedastisitas

Setelah dilakukan pengujian asumsi klasik dan diperoleh kesimpulan bahwa model telah dapat digunakan untuk dilakukan pengujian analisis regresi berganda, maka langkah selanjutnya adalah melakukan pengujian hipotesis. Hipotesis yang diuji adalah Budaya Organisasi, Motivasi Kerja, dan Kepemimpinan berpengaruh terhadap Kepuasan Masyarakat atas Layanan di SKPD yang ada di Kota Medan.

$$
\begin{aligned}
& \mathrm{KPL}=\beta_{0}+\beta_{1} \mathrm{BO}+\beta_{2} \mathrm{MK}+\beta_{3} \mathrm{~K}+\mathrm{e} \\
& \text { Keterangan : } \\
& \mathrm{KPL}=\text { Kepuasan Masyarakat } \\
& \mathrm{BO}=\text { Budaya Organisasi } \\
& \text { MK = Motivasi Kerja } \\
& \mathrm{K} \quad \text { = Kepemimpinan } \\
& \mathrm{e}=\text { error term }
\end{aligned}
$$




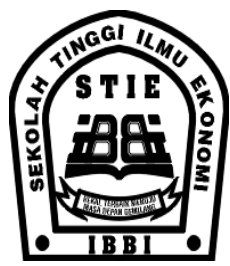

ISSN 1858-3199

JURNAL

MANAJEMEN BISNIS

STIE IBBI

Ringkasan hasil pengujian hipotesis dapat dilihat pada tabel 5.9 berikut ini:

Tabel 5. Pengujian Model

\begin{tabular}{|l|r|r|r|r|}
\hline \multicolumn{1}{|c|}{ Keterangan } & B & $\begin{array}{c}\text { Standard } \\
\text { Error }\end{array}$ & t & Signifikansi \\
\hline Konstan & -0.389 & 0.730 & -0.533 & 0.595 \\
\hline Budaya organisasi (BO) & -0.004 & 0.007 & -0.536 & 0.592 \\
\hline Motivasi Kerja (MK) & 0.007 & 0.015 & 0.450 & 0.654 \\
\hline Kepemimpinan (K) & 0.175 & 0.045 & 3.855 & 0.000 \\
\hline R Model & \multicolumn{4}{|c|}{0,877} \\
\hline $\mathrm{R}^{2}$ Model & \multicolumn{5}{|c|}{0,769} \\
\hline $\mathrm{F}_{\text {Hitung }}$ & \multicolumn{5}{|c|}{0,000} \\
\hline Signifikansi model & \multicolumn{5}{|c}{} \\
\hline
\end{tabular}

Sumber : Data olahan SPSS

Nilai R pada intinya untuk mengukur seberapa besar hubungan antara independen sebesar 0,877. Hal ini menunjukkan bahwa variabel Budaya Organisasi (BO), Motivasi Kerja (MK), dan Kepempinan (K) mempunyai hubungan yang cukup kuat dengan Kepuasan Masyarakat.Sedangkan nilai $\mathrm{R}^{2}$ atau nilai koefisien determinasi pada intinya mengukur seberapa jauh kemampuan model dalam menerangkan variasi variabel dependen. Nilai adalah di antara nol dan satu. Nilai $\mathrm{R}^{2}$ sebesar 76.9\% dapat dikatakan relatif besar. Hal ini berarti bahwa Kepuasan Masyarakat mampu dijelaskan oleh Budaya Organisasi, Motivasi Kerja, dan Kepemimpinan sebesar 76.9\%, sedangkan sisanya sebesar $22.1 \%$ dijelaskan oleh faktor lainnya.

Dari uji ANOVA didapat $F_{\text {hitung }}$ sebesar 195,849 dengan tingkat singkat signifikan 0,000. Karena probabilitas 0,000 lebih kecil dari 0,05, maka hasil dari model regresi menunjukkan bahwa ada pengaruh Budaya Organisasi, Motivasi Kerja, dan Kepemimpinan secara bersama-sama terhadap Kepuasan Masyarakat. Berdasarkan hasil uji hipotesis yang terdapat dalam tabel 5.9 dapat dilihat bahwa, secara parsial variabel Budaya Organisasi didapatkan $\mathrm{t}_{\text {hitungsebesar }-0,536 \text { dengan }}$ tingkat nilai signifikasi sebesar 0,592 dan dapat dinyatakan bahwa persepsi karaywan atas Budaya Organisasi tidak berpengaruh parsial terhadap kepuasan masyarakat di SKPD kota Medan. Motivasi Kerja memiliki nilai $t_{\text {hitung }}$ 0,450 dengan signifikansi sebesar 0,654 yang dapat diartikan bahwa Motivasi Kerja tidak berpengaruh terhadap Kepuasan Masyarakat pada SKPD di kota Medan.

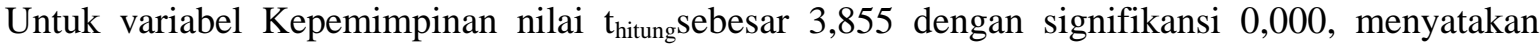
bahwa Kepemimpinan mempengaruhi Kepuasan Masyarakat di SKPD kota Medan.

\section{Pembahasan}

Kepuasan masyarakat merupakan menjadi salah satu tujuan utama pelayanan publik yang diberikan oleh Satuan Kerja Perangkat Daerah (SKPD) termasuk SKPD yang ada di Kota Medan. Seluruh aktifitas manajerial yang dilaksanakan di pemerintahan harus menghasilkan suatu layanan yang memberikan kepuasan bagi setiap masyarakat yang berurusan pada suatu instansi tertentu. Kepuasan sendiri akan sangat dipengaruhi oleh ekspektasi masyarakat atas layanan yang akan diterimanya. Pada umumnya masyarakat mengharapkan suatu layanan yang baik, cepat, dan menyelesaikan kebutuhan tertentu yang ingin dicapainya pada saat itu. Setiap pegawai SKPD harus mampu memberikan layanan sesuai dengan ekspektasi masyarakat tersebut.

Konsep diatas terlihat secara jelas dari hasil penelitian ini dimana layanan yang diberikan SKPD sangat mempengaruhi kepuasan masyarakat. Variabel independen memang tidak secara langsung mengukur kualitas layanan yang diberikan namun melihat berbagai faktor yang sangat 

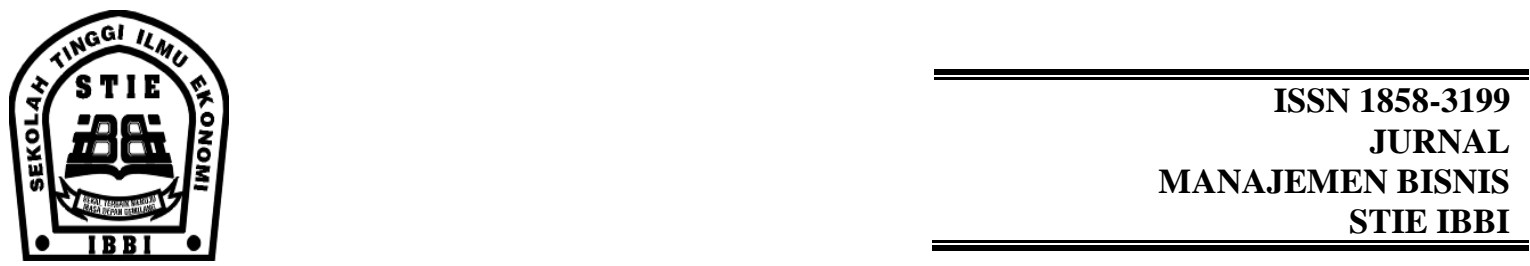

mempengaruhi kualitas layanan. Faktor-faktor tersebut antara lain adalah budaya organisasi, motivasi kerja dan kepemimpinan. Ketiga variabel tersebut secara statistik memberikan pengaruh yang signifikan terhadap kepuasan masyarakat. Besaran pengaruh yang diberikan juga cukup besar yaitu 76.9\%. Tingkat pengaruh sebesar itu relatif besar apalagi jika dilihat dari level signifikansi menunjukkan tingkat signifikansi yang sangat tinggi.

Implikasi logis dari hasil temuan ini adalah dimana pimpinan setiap SKPD harus memperhatikan ketiga faktor tersebut jika ingin memberikan layanan publik yang memuaskan. Pimpinan harus mampu menciptakan suatu budaya organisasi yang mendukung peningkatan kualitas layanan publik, kondisi yang mendorong motivasi kerja yang tinggi, dan kepemimpinan yang mampu mengarahkan suatu aktifitas pelayanan operasional yang memuaskan. Jika hal-hal tersebut dapat berlangsung dengan baik maka sangat dimungkinakan menghasilkan suatu layanan yang berkualitas dimana masyarakat akan memperoleh kepuasan atas layanan publik yang diterimanya.

Namun demikian jika ditinjau secara parsial atas masing-masing variabel maka diperoleh hasil yang tidak seragam. Variabel budaya organisasi secara statistik tidak memberikan pengaruh yang signifikan. Analisis yang dilakukan terhadap hasil ini menunjukkan beberapa dugaan yang mungkin mengakibatkan hal tersebut. Secara umum dapat diperhatikan bahwa budaya organisasi yang terbentuk di lingkungan pemerintahan daerah relatif tidak memiliki suatu pola yang jelas. Budaya organisasi relatif tidak kuat dimana hal tersebut lebih dipengaruhi oleh figur pemimpin di SKPD tersebut. Tidak terdapat suatu pola yang khas dari suatu SKPD yang secara jelas menunjukkan karakteristik khusus. Data yang dihasilkan dari kondisi tersebut jika diuji pengaruh signifikansinya akan menunjukkan hubungan yang tidak jelas dengan kepuasan pelanggan.

Namun demikian hal ini bukan berarti bahwa budaya organisasi menjadi suatu hal yang tidak perlu diperhatikan. Hasil ini hanya menunjukkan bahwa belum ditemukan suatu pola budaya organisasi yang secara khas mempengaruhi kualitas layanan publik. Kemungkinan jika pimpinan mampu membentuk suatu layanan budaya oragnisasi yang kuat maka kualitas layanan publikakan relatif terjaga dan tidak tergantung pada pemimpin yang sedang menjabat di suatu SKPD. Hal ini memberikan konsekuensi agar pimpinan tertinggi yaitu walikota perlu berusaha meletakkan dasardasar yang kuat dalam pembentukan budaya organisasi baik menyangkut bidaya kerja, budaya komunikasi dan budaya lainnya. Hal ini akan mendorong suatu layanan yang jauh lebih permanen.

Variabel berikutnya yang diteliti adalah motivasi kerja. Sama halnya dengan budaya organisasi, variabelmotivasi kerja juga tidak menunjukkan pengaruh yang signifikan. Jika dianalisis lebih mendalam memang dapat dilihat bahwa motivasi kerja staf suatu SKPD relatif tidak jelas atau pola yang kuat. Pelaksanaan suatu pekerjaan lebih dipengaruhi hal-hal lain seperti tekanan pimpinan, keharusan, dan berbagai faktor lain yang bukan berasal dari motivasi internal diri. Pelaksanaan tugas untuk memberikan layanan buka didorong sesuatu yang lahir dari dalam diri misalnya karena keinginan promosi, keinginan kenaikan gaji dan berbagai unsur pembangkit motivasi internal yang umum digunakan di dalam perusahaan profit. Hal ini mengindikasikan bahwa hasil kinerja seseorang kemungkinan tidak memiliki pola hubungan yang searah dengan pemerian reward baik reward promosi maupun upah materi lainnya.

Implikasi dari hal ini adalah bahwa pimpinan seharusnya mampu menemukan dan mengembangkan faktor-faktor yang mampu mendorong motivasi kerja. Jika merujuk pada perusahaan swasta maka motivasi kerja karyawan pada umumnya timbul dari jenjang karir yang jelas, sistem pengupahan yang berkaitan dengan kinerja, dan reward lainnya yang diberikan berdasarkan kinerja. Hal ini relatif tidak ditemukan di SKPD yang ada di kota Medan. Dalam kaitan ini ketika unsur motivasi kerja tidak secara nyata hadir dalam pelaksanaan kerja maka variabel ini 

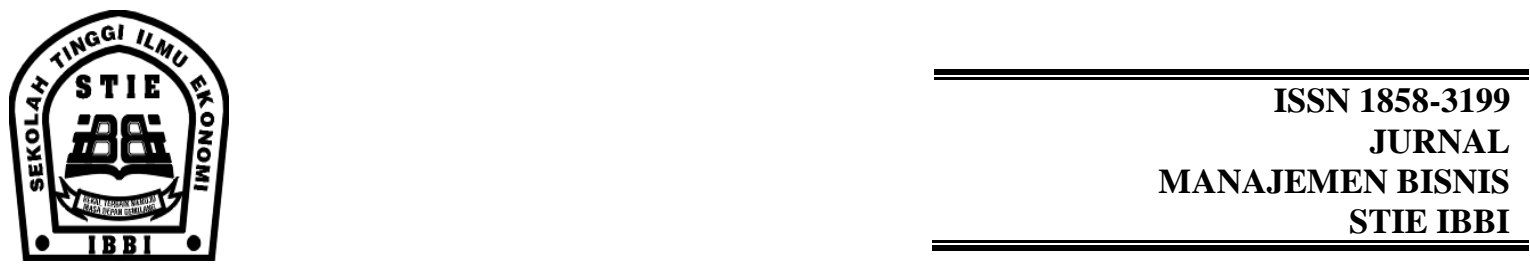

menjadi memiliki pengaruh yang tidak signifikan terhadap pemberian layanan publik. Jika hal-hal tersebut mampu dikembangkan maka karyawan dan staf akan lebih terdorong untuk memberikan layanan yang baik dan berkualitas.

Variabel ketiga yang diteliti dalam penelitian ini adalah kepemimpinan. Variabel ini menjadi satu-satunya variabel yang memberikan pengaruh parsial yang signifikan. Hal ini berarti kepemimpinan akan sangat mempengaruhi kualitas layanan publik yang pada kelanjutannya memberikan pengaruh yang signifikan terhadap kepuasan masyarakat. Sejalan dengan penjelasan diatatas, hal ini menunjukkan bahwa figur pimpinan di suatu SKPD ternyata menjadi hal yang paling menentukan layanan yang diberikan di SKPD Terebut. Hal ini dapat dikatakan baik namun memiliki dampak negatif yang berbahaya dimana suatu instansi relatif bergantung pada individu tertentu sehingga rotasi dan pergantian pimpinan akan sangat mempengaruhi layanan publik yang diberikan.

Memang dapat dimengerti bahwa figur pimpinan akan sangat mempengaruhi pelayanan yang diberikan oleh SKPD namun demikian hal tersebut tidak boleh berlangsung secara terus menerus. Pimpinan tertinggi dalam hal ini walikota harus mampu menciptakan suatu sistem kerja yang tidak tergantung pada orang namun sudah sangat terbentuk menjadi suatu budaya organisasi yang mendukung pemberian layanan prima bagi masyarakat. Penempatan pemimpin di suatu SKPD bukan menjadi unsur terpenting dari proses pemberian layanan publik namun hanya menjadi penyangga dari suatu sistem kerja yang telah terbangun. Namun demikian bukan berarti kepemimpinan menjadi suatu variabel yang dapat dikesampingkan. Kepemimpinan tetap memiliki pengaruh yang signifikan karena hal tersebut jugamemberikan jaminan layanan publik yang baik.

Berdasarkan penjelasan diatas dapat dilihat bahwa hasil penelitian ini cenderung sesuai dengan fenomena yang terdapat di masyarakat. Kepemimpinan menjadi faktor yang paling menentukan keberhasilan suatu SKPD. Dalam banyak pemberitaan juga dapat dilihat bahwa pergantian pimpinan suatu SKPD akan membawa perubahan yang signifikan di dalam suatu SKPD. Hal ini tidak baik karena akan membuat organmisasi terus melakukan reformasi yang tidak akan pernah menghantarkan organisasi teresbut menjadi organisasi yang matang dan dewasa. Organisasi tersebut akan tetap tergantung pada individu.

Pada tingkatan yang lebih tinggi hal ini juga terjadi bahwa pimpinan tertinggi yaitu walikota akan memberikan pengaruh yang sangat jelas terhadap layanan SKPD secara keseluruhan. Ketergantungan pada figur orang menjadi suatu hal yang sangat mempengaruhi Pimpinan seharusnya tidak perlu menyusun program kerja sendiri namun melaksanakan suatu rencana jangka panjang yang telah disusun secara matang. Perubahan kebijakan yang mengikuti perubahan pemimpin hanya akan membuat arah pembangunan dan pengembangan menjadi tidak jelas. Hal ini bukan hanya membuat pencapaian tujuan pembangunan menjadi tidak jelas namun juga menimbulkan inefisiensi yang besar dimana hal-hal yang telah dimulai pimpinan sebelumnya terjadang tidak diikuti oleh pimpinan berikut malahan memulai kembali sesuatu yang baru. Hal tersebut akan kembali terulang pada pimpinan selanjutanya yang menggantikan pimpinan tersebut.

Saran yang dapat diberikan adalah perlunya membuat suatu perencanaan kerja yang membentuk suatu budaya organisasi agar organisasi SKPD menjadi suatu unit yang memiliki sistemyang matang. Setiap unit harus memiliki rencana kerja jangka panjang dimana pimpinan yang silih berganti bekerja dalam kerangka kerja yang telah disusun tersebut. Seorang pimpinan tidak perlu menyusun rencana kerja baru namun merancang suatu strategi tingkat operasional untuk mencapai rencana yang telah ditetapkan tersebut. Hal ini akan lebih menjamin kesinambungan dan arah kerja yang jelas. Dampak lanjutan yang diberikan adalah layanan yang diberikan kepada masyarakat menjadi tidak tergantung pada individu tertentu. 


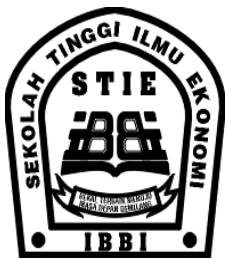

ISSN 1858-3199

JURNAL

MANAJEMEN BISNIS

STIE IBBI

\section{KESIMPULAN DAN SARAN}

Berdasarkan pengujian data yang diperoleh, kesimpulan dari penelitian ini adalah :

1. Budaya organisasi, motivasi kerja, dan kepemimpinan jika diuji secara bersama memiliki pengaruh yang signifikan terhadap kepuasan masyarakat.

2. Besaran pengaruh ketiga variabel independen secara bersama relatif besar yaitu sebesar $77 \%$.

3. Jika diuji secara individual maka hanya variabel kepemimpinan yang memiliki pengaruh parsial yang signifikan terhadap kepuasan masyarakat.

Berdasarkan hasil dan pembahasan yang telah disampaikan pada bagian sebelumnya, maka dapat disampaikan beberapa saran berikut ini :

1. Pemerintah Kota Medan dalam hal ini khususnya walikota perlu berusaha membangun suatu budaya organisasi yang jelas dan kuat. Buday aorganisasi tersebut sangat diperlukan agar terdapat suatu ciri dan karateristik dari seluruh SKPD yang ada di Kota Medan. Budaya organisasi yang dibangun tersebut harus mendukung pemberian layanan publik yang prima. Pembangunan budaya organisasi dapat dimulai dari kantor walikota dan kemudia ditularkan ke SKPD melalui kepala dinas dan atau kepala badan yang diangkat.

2. Motivasi kerja staf SKPD yang terbukti secara empiris tidak mempengaruhi kepuasan masyarakat kemungkinan besar diakibatkan tidak terdapat sistem reward yang baik. Reward tersebut dapat berbentuk jalur promosi karir dan atau gaji ataupun insentif. Sistem ini diduga tidak terimplementasi dengan baik dalam sistem kerja di SKPD yang ada di Kota Medan. Diperlukan upaya yang serius agar terdapat suatu sistemreward yang memungkinakan hal tersebut menjadi sumber motivasi kerja bagi staf SKPD.

3. Kepemimpinan seperti yang terlihat dalam pengujian statitistik menunjukkan pengaruh yang signifikan. Hal ini secara nyata juga dapat dilihat di masyarakat bahwa mayoritas staf SKPD akan sangat mematuhi kelapa di SKPD masing-masing. Hal ini dapat memberikan dampak positif sekaligus negatif. Dampak positif adalah mudahnya melakukan aktifitas manajemen sesuai kemauan pimpinan, namun pada sisi lain hal ini membuat setiap SKPD bergantung pada individu. Hal ini perlu diperhatikan oleh walikota agar dapat mengubah hal tersebut. Salah satu cara untuk mengubahnya adalah menciptakan budaya organisasi yang tidak berpusat pada orang tertentu tetapi membangun sistem yang baik. Sistem tersebut menempatkan seluruh kompenen mengambil peran sesuai bagiannya tanpa harus terlalu bergantung pada satu individu tertentu.

\section{DAFTAR PUSTAKA}

Alvesson, Mats.2013.Understanding Organizational Culture, Second Edition.London:SAGE.

Aribowo, Risky N.2011.Pengaruh Kepemimpinan, Motivasi Dan Lingkungan Kerja Fisik Terhadap Kinerja Pegawai pemerintahan (Studi Pada Cv. Karya Mina Putra Rembang Devisi Kayu). Semarang:UNDIP.

Arrizal.2010.Teori Kepemimpinan Ciri:Asmaul Husna. Jurnal Manajemen Vol.203, 20 September 2010, Padang. http : // jurnal. Unitaspdg . ac . id / files / 31 / Jurnal \% 20 Manajemen/Vol\%203\%20September\%202010/1.\%20Teori\%20Kepemimpinan\%20Ciri\% 20_\%20Asmaul\%20Husna.pdf 


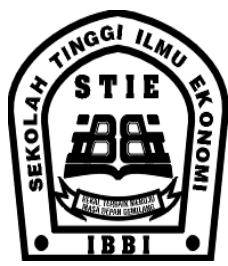

ISSN 1858-3199

JURNAL

MANAJEMEN BISNIS

STIE IBBI

Bass, Bernard M. dan Bass, Ruth.2008.The Bass Handbook Of Leadership-Theory Research \& Managerial Application. New York: Free Press. A division of Simon \& Schuster, Inc.

Cahyono, Dwi.2008.Persepsi Ketidakpastian Lingkungan, Ambiguitas Peran Dan Konflik Peran Sebagai Mediasi Antara Program Mentoring Dengan Kepuasan Kerja, Prestasi Kerja Dan Niat Ingin PindahStudi Empiris Di Lingkungan Kantor Akuntan Publik (Kap) Besar. Semarang:UNDIP

Gaspersz, Vincent, 2003, "Balanced Scorecard Dengan Six Sigma : Untuk Organisasi Bisnis Dan Pemerintahan", PT Gramedia Pustaka Utama, Jakarta.

Hardjosoekarto, S. 2000. Bisnis dan Birokrasi Nomor 3/Vol. IV/September.

Hernandez, Morela. Promoting Stewardship Behavior in Organizations: Leadership Model.Journal of Business Ethics (2008) 80:121-128 DOI 10.1007/s10551-007-94402.http://link.springer.com/article/10.1007/s10551-007-9440-2\#page-2 http://books.google.co.id/books?id=ikQcBGrV9swC\&printsec=frontcover\&dq=organizati onal+culture\&hl=en\&sa=X\&ei=eHIUUa2sHY yrQfPvYHQDg\&ved=0CC8Q6AEwATg $\mathrm{K} \# \mathrm{v}=$ onepage $\& \mathrm{q}=$ organizational\%20culture \&f=false http://kardie.blog.undip.ac.id/2009/09/15/analisis-faktor-faktor-yang-mempengaruhiprestasi-kerjal

Instruksi Presiden Republik Indonesia No. 1 Tahun 1995.

Kardi.2009. Analisis Faktor Faktor Yang Mempengaruhi Prestasi Kerja.Semarang: UNDIP

Keputusan Menteri Negara Pendayagunaan Aparatur Negara No. 81 Tahun 1995.

Kets de Vries. (1997). The Entrepreneurial Personality, A Person at The Cross Roads, Journal of Management Studies, $14: 34-57$.

Kouzes, James.M dan Posner, Barry Z.2010.The Leadership Challenge. Workbook, Fourth Edition (http://www.google.co.id/books?hl=en\&lr=\&id=5zSRaMCHA80C\&oi=fnd\&pg=PT15\&d q=related:C-j01OQacdkJ:scholar.google.com/\&ots=SfBBE5wurc\&sig=jE7d-LjrtBuhpkDnYAid1Ui2us\&redir esc $=\mathrm{y} \# \mathrm{v}=$ onepage $\& \mathrm{q} \& \mathrm{f}=\mathrm{false}$ )

Kusumawati, Ratna.2008.Analisis Pengaruh Budaya Organisasi dan Gaya Kepemimpinan terhadap Kepuasan Kerja untuk Meningkatkan Kinerja Pegawai pemerintahan. Semarang:UNDIP

Londong, Dedy.2012.KepuasanKerja (Job Satisfaction). http://dedylondong.blogspot.com/2011/11/kepuasan-kerja-job-satisfaction.html(Hasibuan, M.2007, Manajemen Sumber Daya Manusia, Bumi Aksara, Indonesia Jakarta, hal. 202)

Low, Patrick K.C.2011.Inner Leadership-What it takes to be a Leader. Business Journal for Entrepreneurs, Vol.2011, No.4, pp.10-15,2011.

Mansyur.2011.Faktor-faktor yang Mempengaruhi Prestasi Kerja.Jakarta. http://watanlamahala.blogspot.com/2011/07/faktor-faktor-yang-mempengaruhi.html

Mariam, Rani.2009.Pengaruh Gaya Kepemimpinan Dan Budaya Organisasi Terhadap Kinerja Pegawai pemerintahan Melalui Kepuasan Kerja Pegawai pemerintahan Sebagai Variabel Intervening Studi Pada Kantor Pusat PT.Asuransi Jasa Indonesia (Persero). Semarang:UNDIP

Msoroka, Mohamed.2011.Organizational Culture: Its implications to educational Institutions.Germany:Grin.(http://books.google.co.id/books?id=z0VW0KnkcG4C\&pg=PT 38\&lpg=PP1\&dq=organizational+culture)

Rector, Teresa.2007.Corporate Culture Shock.Lulu. 


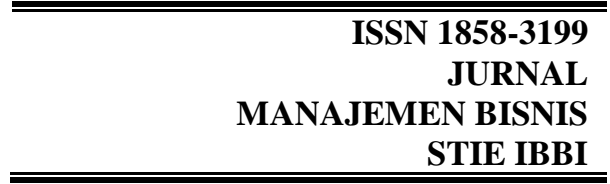

Rofai, Achmad.2006.Analisis Faktor-Faktor yang Mempengaruhi Efektivitas Organisasi pada Badan Kesatuan Bangsa dan Perlindungan Masyarakat Propinsi Jawa Tengah. Semarang:UNDIP.

Sveningsson dan Alvesson.2008.Changing Organizational Culture.New York:Routledge.

Wardani, Eka S.2009.Pengaruh Kompensasi, Keahlian dan Motivasi Kerja Terhadap Prestasi Kerja Pegawai pemerintahan Pada PT.Pembangkitan Jawa Bali Unit Pembangkitan Muara Tawar. Universitas Gunadarma.

Yetiskin, Saadet.2009.Flow, motivation, and job-change history in British and Hong Kong Chinese workers. Germany:Grin. 


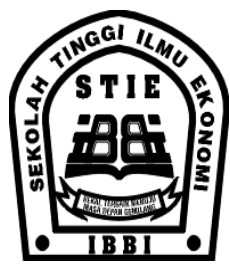

ISSN 1858-3199

JURNAL

MANAJEMEN BISNIS

STIE IBBI

\title{
PENGARUH MOTIVAI, PERSEPSI, PEMBELAJARAN, DAN KEPRIBADIAN TERHADAP KEPUTUSAN KONSUMEN MEMBELI SEPEDA MOTOR BEKAS DI KOTA MEDAN
}

\author{
Djatmiko Noviantoro, SE., M.Si \\ Lusiah, SE., MM \\ Dosen Tetap STIE IBBI Medan
}

\begin{abstract}
ABSTRAK
Tujuan penelitian ini adalah untuk mengetahui pengaruh motivasi, persepsi, pembelajaran, dan kepribadian terhadap keputusan konsumen membeli sepeda motor bekas di Kota Medan. Metode penelitian yang digunakan dalam penelitian ini adalah dengan pendekatan survey, jenis penelitian adalah deskriptif kuantitatif, dan sifat penelitiannya adalah penjelasan. Sampel dalam penelitian ini adalah konsumen pengguna sepeda motor bekas yang berjumlah 400 orang dan tersebar di seluruh kecamatan wilayah Kotamadya Medan. Kesimpulan yang dapat diambil dari hasil pengujian menunjukkan bahwa secara serempak motivasi, persepsi, pembelajaran, dan kepribadian berpengaruh signifikan terhadap keputusan membeli sepeda motor bekas. Sedangkan secara parsial variabel motivasi berpengaruh lebih dominan daripada variabel persepsi, pembelajaran, dan kepribadian.
\end{abstract}

Kata kunci: motivasi, persepsi, pembelajaran, kepribadian, keputusan membeli.

\section{PENDAHULUAN}

Kendaraan merupakan alat transportasi yang dapat mempermudah manusia dalam melakukan aktivitas tertentu dari suatu tempat ke tempat lainnya. Sejak ditemukannya alat transportasi tersebut, gerak hidup manusia berubah menjadi lebih mudah dan dinamis. Kita mengetahui ada beberapa jenis kendaraan yang digunakan oleh manusia dalam beraktivitas, diantaranya kendaraan yang digerakkan menggunakan tenaga manusia seperti sepeda dan becak, lalu ada kendaraan yang digerakkan menggunakan tenaga hewan seperti andong atau delman, dan ada pula kendaraan yang digerakkan menggunakan tenaga mesin seperi sepeda motor, mobil, kapal, pesawat dan lain-lain. Semua kendaraan tersebut dibuat sesuai dengan kebutuhan setiap manusia yang berbeda-beda.

Semakin berkembangnya zaman, maka kendaraan yang menggunakan tenaga manusia dan hewan mulai ditinggalkan dengan berbagai alasan tertentu. Perlahan namun pasti bahwa kendaraan yang menggunakan tenaga mesin menjadi pilihan utama bagi setiap orang dalam melakukan aktivitas perjalanan tertentu, apalagi jarak yang harus ditempuh dalam suatu perjalanan tergolong jauh.

Salah satu kendaraan yang menjadi primadona dalam kurun waktu dua dasawarsa terakhir ini adalah kendaraan yang digerakkan tenaga mesin dan beroda dua, atau yang dikenal dengan sepeda motor. Tingginnya tingkat mobilitas seseorang dalam melakukan perjalanan tertentu menuntut setiap orang memiliki kendaraan yang mudah dioperasionalkan, efektif dan efisien. Pilihan kendaraan seperti ini tentu saja terjawab dengan keberadaan sepeda motor. Selain itu, apabila dilihat dari segi biaya, harga pembelian dan perawatan sepeda motor jauh lebih rendah dibanding dengan kendaraan lain, seperti mobil. 


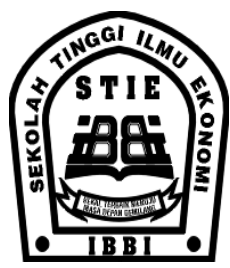

ISSN 1858-3199

JURNAL

MANAJEMEN BISNIS

STIE IBBI

Berkembangnya kebutuhan konsumen akan keberadaan sepeda motor tertentu mendorong berbagai produsen sepeda motor menciptakan jenis-jenis sepeda motor yang disesuaikan dengan kebutuhan masing-masing konsumen. Banyaknya jenis sepeda motor terbaru, ditambah dengan semakin gencar iklan tentang sepeda motor-sepeda motor terbaru, membuat sebagian konsumen tertarik dan terdorong untuk mengganti atau menjual sepeda motor yang lama, kemudian membeli sepeda motor keluaran terbaru. Hal ini mengakibatkan tersedianya sepeda motor bekas yang masih layak pakai untuk kembali diperjualbelikan kepada konsumen lain.

Peningkatan penjualan sepeda motor bekas menjadi suatu fenomena tersendiri di tengahtengah pesatnya kemajuan teknologi sepeda motor belakangan ini yang dilakukan oleh produsenprodusen terkemuka seperti Honda, Yamaha, Suzuki dan lain-lain. Hal ini menunjukkan bahwa tidak semua konsumen menginginkan membeli sepeda motor baru berdasarkan teknologinya saja, namun ada hal lain yang menentukan konsumen untuk melakukan pembelian sepeda motor bekas. Berdasarkan hasil survey awal yang dilakukan, beberapa konsumen mengatakan bahwa harga sepeda motor baru masih terlalu mahal bagi mereka. Sehingga calon pembeli yang kemampuan daya belinya masih tergolong rendah, membeli sepeda motor bekas merupakan salah satu pilihannya.

Tersedianya peluang bisnis jual-beli sepeda motor bekas di Kota Medan berdampak pada tumbuhnya persaingan dalam kegiatan usaha sejenis. Seiring dengan berjalannya waktu, maka tingkat persaingan usaha ini semakin tinggi. Berdasarkan kondisi ini maka setiap pelaku usaha harus cermat dalam menerapkan strategi pemasaran yang tepat agar konsumen dapat menentukan keputusannya untuk membeli sepeda motor bekas di tempat mereka. Hal ini dapat dilakukan dengan mengetahui pertimbangan-pertimbangan konsumen dalam melakukan pembelian. Beberapa pendekatan yang dapat digunakan untuk mengetahui pertimbangan konsumen dalam menetukan keputusan membelinya adalah dengan cara mempelajari bagaimana motivasi, persepsi, pembelajaran, dan kepribadian konsumen dalam melakukan keputusan pembelian sepeda motor bekas di Kota Medan.

Akhirnya dengan melihat dan mempertimbangkan keempat faktor yang mempengaruhi perilaku konsumen untuk memilih pembelian sepeda motor bekas, maka pelaku usaha jual-beli sepeda motor bekas akan lebih memahami kebutuhan dan keinginan dari konsumen sehingga strategi yang diterapkan juga tentunya akan lebih baik dan berhasil.

Berdasarkan uraian di atas, maka penulis tertarik untuk mengadakan penelitian lebih lanjut dalam rangka mengetahui pengaruh motivasi, persepsi, pembelajaran, dan kepribadian terhadap keputusan konsumen membeli sepeda motor bekas di Kota Medan.

\section{TINJAUAN PUSTAKA \\ Penelitian Terdahulu}

Ulfah (2010), melakukan penelitian dengan judul "Analisis Faktor-faktor Internal yang Mempengaruhi Keputusan Konsumen Membeli Mobil Bekas di Kota Medan". Tujuan penelitiannya adalah untuk mengetahui dan menganalisis pengaruh faktor-faktor internal yang terdiri dari: motivasi, persepsi, pembelajaran, dan kepribadian terhadap keputusan konsumen membeli mobil bekas di Kota Medan. Kemudian data yang diperoleh dianalisa dengan menggunakan analisis regresi berganda. Hasil penelitian menunjukkan bahwa, secara serempak faktor motivasi, persepsi, pembelajaran dan kepribadian berpengaruh sangat signifikan terhadap keputusan pembelian mobil bekas di kota Medan. Hal ini disebabkan karena umumnya keputusan pembelian dipengaruhi oleh faktor perilaku konsumen termasuk di dalamnnya adalah motivasi, persepsi, pembelajaran dan kepribadian. Secara parsial variabel persepsi berpengaruh lebih dominan daripada motivasi, 


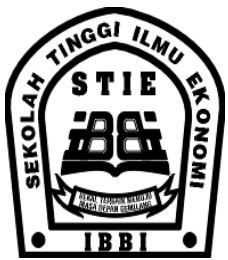

ISSN 1858-3199

JURNAL

MANAJEMEN BISNIS

STIE IBBI

pembelajaran dan kepribadian. Maksudnya adalah, variabel persepsi lebih menentukan dalam mempengaruhi keputusan pembelian mobil bekas di Kota Medan.

\section{Teori tentang Motivasi}

Kata motivasi (motivation) berasal dari kata dasar motif (motive) yang berarti dorongan, sebab atau alasan seseorang melakukan sesuatu. Simamora (2003) menyatakan bahwa, "Motif adalah suatu kebutuhan yang cukup menekan seseorang untuk mengejar kepuasan".

Kotler (2007) menyatakan bahwa, "seseorang memiliki banyak kebutuhan pada waktu tertentu. Beberapa kebutuhan bersifat biogenis yaitu kebutuhan tersebut muncul dari tekanan biologis seperti rasa lapar, haus, tidak nyaman. Kebutuhan yang lain bersifat psikogenis yaitu kebutuhan itu muncul dari tekanan psikologis seperti kebutuhan akan pengakuan, penghargaan, atau rasa keanggotaan kelompok".

\section{Klasifikasi Motivasi}

Setiadi (2003) menyatakan bahwa, "motivasi yang dimiliki tiap konsumen sangat berpengaruh terhadap keputusan yang akan diambil. Bila dilihat dari hal itu maka motivasi yang dimiliki oleh konsumen secara garis besar dapat terbagi dua kelompok besar, antara lain motivasi yang berdasarkan rasional dan motivasi yang berdasarkan emosional. Motivasi yang berdasarkan rasional akan menentukan pilihan terhadap suatu produk dengan memikirkan secara matang serta dipertimbangkan terlebih dahulu untuk membeli produk tersebut. Sedangkan untuk motivasi yang berdasarkan pada emosional, konsumen terkesan terburu-buru untuk membeli prosuk tersebut dengan tidak mempertimbangkan kemungkinan yang akan terjadi untuk jangka panjang”.

\section{Teori tentang Persepsi}

Setiadi (2003) menyatakan bahwa, "persepsi didefinisikan sebagai proses dimana seseorang memilih, mengorganisasikan, mengertikan masukan informasi untuk menciptakan suatu gambaran yang berarti dari dunia ini”.

Shiffman dan Kanuk (2007) menyatakan bahwa persepsi adalah "sebagai proses yang dilakukan individu untuk memilih, mengatur, dan menafsirkan stimuli kedalam gambar yang berarti dan masuk akal mengenai dunia".

Kotler (2007) menyatakan bahwa, "persepsi itu lebih penting daripada realitas, karena persepsi itulah yang akan mempengaruhi perilaku aktual konsumen. Orang dapat memiliki persepsi yang berbeda atas objek yang sama karena tiga proses persepsi yaitu perhatian selektif, distorsi selektif dan ingatan selektif.

1. Perhatian selektif. Orang mengalami sangat banyak rangsangan setiap hari. Karena seseorang tidak mungkin dapat menanggapi semua rangsangan itu, kebanyakan rangsangan akan disaring, proses yang dinamakan perhatian selektif. Berdasarkan temuan rangsangan yaitu orang cenderung memerhatikan rangsangan yang berhubungan dengan kebutuhannya saat ini, orang cenderung memerhatikan rangsangan yang mereka antisipasi, dan orang cenderung memerhatikan rangsangan yang berdeviasi besar terhadap ukuran rangsangan normal.

2. Distorsi selektif. Merupakan kecenderungan menafsirkan informasi sehingga sesuai dengan pra-konsepsi kita. Konsumen akan sering memelintir informasi sehingga menjadi konsisten dengan keyakinan awal mereka atas merek dan produk.

3. Ingatan Selektif. Orang akan melupakan banyak hal yang mereka pelajari, tetapi cenderung mengingat informasi yang mendukung pandangan dan keyakinan mereka. 

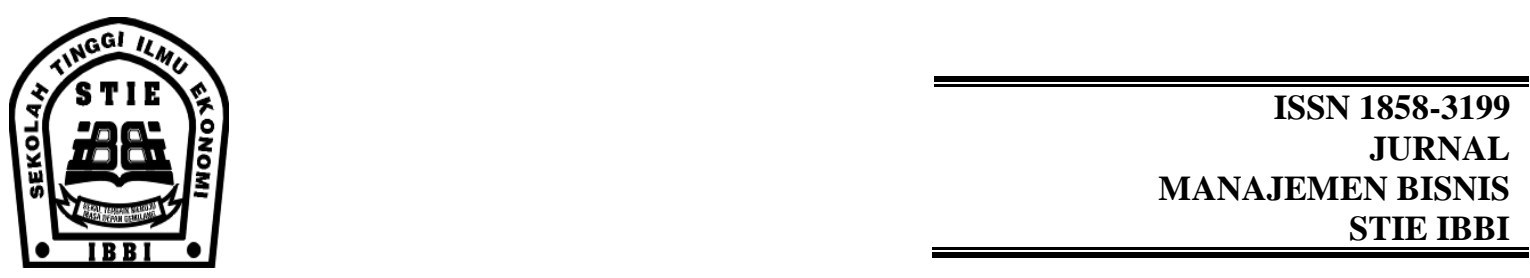

Karena adanya ingatan selektif, kita cenderung mengingat hal-hal baik yang disebutkan tentang produk yang kita sukai dan melupakan hal-hal baik yang disebutkan tentang prosuk pesaing.

4. Persepsi subliminal. Mekanisme persepsi selektif menuntut keterlibatan dan pemikiran aktif pihak konsumen."

\section{Teori tentang Pembelajaran}

Mowen (2002) menyatakan bahwa "pengetahuan diperoleh melalui proses pembelajaran kognitif". Pembelajaran kognitif (cognitive learning) adalah sebuah proses aktif dimana orang berusaha untuk mengendalikan informasi yang mereka dapatkan. Para konsumen belajar baik melalui pendidikan maupun melalui pengalaman.

Schiffman dan Kanuk (2000) menyatakan bahwa pembelajaran adalah "from a marketing perspective, the process by which individuals acquaire the purchase and consuption knowledge and experience that they apply to future related behavior". Yang dapat diartikan dari perspektif pemasaran, proses belajar konsumen dapat diartikan sebagi sebuah proses dimana seseorang memperoleh pengetahuan dan pengalaman pembelian dan konsumsi yang akan ia terapkan pada perilaku yang terkain pada masa datang.

\section{Teori tentang Kepribadian}

Setiadi (2003) menyatakan bahwa, "kepribadian adalah perilaku yang dinamis dari sistem psikofisis individu yang menentukan penyesuaian dirinya terhadap lingkungannya secara unik".

Mowen (2002) menyatakan bahwa, "konsep kepribadian memiliki empat aspek penting yaitu perilaku menunjukkan konsistensi, perilaku membedakan seseorang denngan yang lainnya, perilaku berinteraksi dengan situasi dan pengukuran kepribadian tunggal tidak dapat memprediksi perilaku tertentu".

\section{Teori tentang Perilaku Konsumen}

Perilaku Konsumen merupakan suatu tindakan yang ditunjukkan oleh konsumen dalam hal mencari, menukar, menggunakan, menilai, mengatur barang atau jasa yang mereka anggap akan memuaskan kebutuhan mereka.

Menurut Mowen (2002) bahwa, "perilaku konsumen (consumer behaviour) didefinisikan sebagai studi tentang unit pembelian (buying units) dan proses pertukaran yang melibatkan perolehan, konsumsi dan pembuangan barang, jasa, pengalaman serta ide-ide".

Sedangkan menurut Kotler (2007) bahwa, "perilaku konsumen merupakan studi tentang cara individu, kelompok, dan organisasi menyeleksi, membeli, menggunakan, dan memposisikan barang, jasa, gagasan, atau pengalaman untuk memuaskan kebutuhan dan keinginan mereka".

\section{Kerangka Berpikir}

Agar dapat memenangkan persaingan, maka tentunya pemasar haruslah memahami kondisi pasar dan melakukan analisis yang tepat. Dalam menganalisis kondisi pasar tersebut, pemasar perlu melakukan analisis perilaku konsumen untuk mengidentifikasi bagaimana perilaku membeli konsumen dan proses pembeliannya beserta faktor-faktor yang mempengaruhi pengambilan keputusan pembelian. Analisis perilaku konsumen ditujukan untuk mempelajari bagaimana individu, kelompok, dan organisasi dalam memilih, membeli, menggunakan barang, jasa dan ide untuk memuaskan kebutuhan dan keinginan mereka. Dengan demikian pemasar perlu mempelajari motivasi, persepsi, pembelajaran, dan kepribadian konsumen.

Motivasi adalah keadaan yang diaktivasi atau digerakkan dimana seseorang mengarahkan perilaku berdasarkan tujuan. Dapat diartikan bahwa motivasi muncul karena adanya tujuan yang 


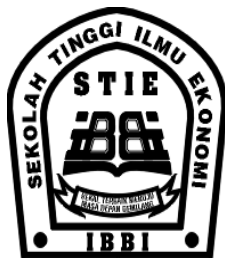

ISSN 1858-3199

JURNAL

MANAJEMEN BISNIS

STIE IBBI

ingin dicapai oleh seseorang. Tujuan ini berdampak pada keputusan seseorang untuk menentukan hal-hal yang dapat memenuhi keinginan akan suatu kebutuhan.

Persepsi merupakan proses yang digunakan individu untuk memilih, mengorganisasi, dan menginterprestasi masukan informasi guna menciptakan gambaran dunia yang memiliki arti. Setiap orang memiliki persepsi yang berbeda atas objek yang sama. Perbedaan persepsi dapat mempengaruhi seseorang dalam pengambilan keputusan.

Pembelajaran adalah perubahan perilaku yang relatif permanen yang diakibatkan oleh pengalaman. Proses pembelajaran menjelaskan perubahan dalam perilaku seseorang yang timbul dari pengalaman. Pada umumnya perilaku konsumen merupakan hasil proses pembelajaran. Dengan pembelajaran seseorang akan selektif dalam menentukan keputusan.

Kepribadian merupakan ciri bawaan psikologis manusia yang khas, menghasilkan tanggapan yang relatif konsisten dan bertahan lama terhadap rangsangan lingkungannya. Setiap orang mempunyai kepribadian yang khas ini dan akan mempengaruhi perilaku pembeliannya. Kepribadian sangat bermanfaat untuk menganalisis perilaku konsumen bagi beberapa pilihan produk atau merek.

Berdasarkan penjelasan teoritis diatas, maka kerangka berpikir penelitian ini dapat digambarkan sebagai berikut:

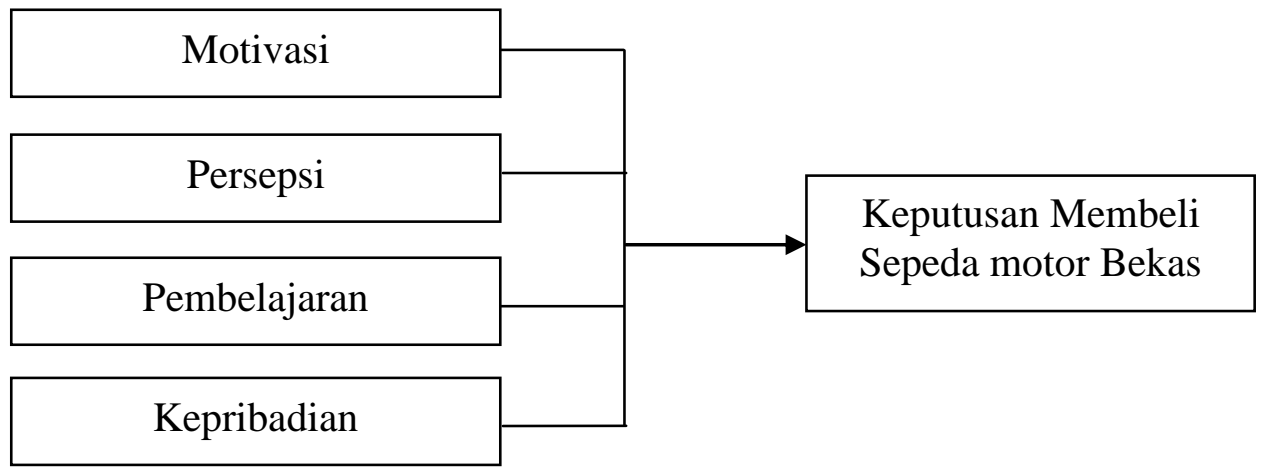

\section{Hipotesis}

\section{Gambar Kerangka Berpikir Hipotesis}

Hipotesis penelitian ini adalah sebagai berikut :

Motivasi, persepsi, pembelajaran, dan kepribadian berpengaruh terhadap keputusan pembelian sepeda motor bekas di Kota Medan.

\section{TUJUAN DAN MANFAAT PENELITIAN Tujuan Penelitian}

Adapun tujuan penelitian ini adalah adalah untuk mengetahui dan menganalisis pengaruh motivasi, persepsi, pembelajaran, dan kepribadian terhadap keputusan konsumen membeli sepeda motor bekas di Kota Medan.

\section{Manfaat Penelitian}

Manfaat dari penelitian ini adalah:

1. Sebagai sumber informasi bagi pelaku usaha jual-beli sepeda motor bekas untuk dapat menentukan kebijakan dan pengembangan strategi pemasaran yang sesuai dengan 
kebutuhan pasar, khususnya perilaku konsumen dalam membeli sepeda motor bekas di Kota Medan.

2. Sebagai penambah dan memperluas pengetahuan bagi peneliti dalam bidang pemasaran khususnya perilaku konsumen yang berkaitan dengan pengambilan keputusan pembelian.

3. Sebagai bahan referensi bagi peneliti selanjutnya yang akan melakukan penelitian pemasaran di masa yang akan datang.

\section{METODE PENELITIAN}

\section{Lokasi Penelitian}

Penelitian ini akan dilakukan di wilayah Kota Medan. Penelitian ini akan dilaksanakan pada bulan September 2013 sampai dengan bulan November 2013.

\section{Deskripsi Operasional Variabel}

Deskripsi operasional variabel penelitian dapat dilihat pada tabel berikut:

Tabel Deskripsi Operasional Variabel

\begin{tabular}{|c|c|c|c|}
\hline $\begin{array}{c}\text { Variabel } \\
\text { Penelitian }\end{array}$ & Definisi Variabel & Indikator & Pengukuran \\
\hline $\begin{array}{l}\text { Motivasi } \\
\left(\mathrm{X}_{1}\right)\end{array}$ & $\begin{array}{l}\text { Faktor yang mendorong } \\
\text { konsumen untuk melakukan } \\
\text { tindakan pembelian untuk } \\
\text { memenuhi kebutuhannya. }\end{array}$ & $\begin{array}{l}\text { 1. Kebutuhan } \\
\text { 2. Keinginan yang tidak } \\
\text { terpenuhi } \\
\text { 3. Harapan }\end{array}$ & Skala Likert \\
\hline $\begin{array}{l}\text { Persepsi } \\
\left(\mathrm{X}_{2}\right)\end{array}$ & $\begin{array}{l}\text { Sekumpulan tahap pengolahan } \\
\text { informasi yang akan } \\
\text { menstimulus konsumen } \\
\text { terhadap keputusan pembelian. }\end{array}$ & $\begin{array}{l}\text { 1. Menerima informasi } \\
\text { 2. Memperhatikan } \\
\text { informasi } \\
\text { 3. Pemahaman informasi }\end{array}$ & Skala Likert \\
\hline $\begin{array}{c}\text { Pembelajaran } \\
\left(\mathrm{X}_{3}\right)\end{array}$ & $\begin{array}{l}\text { Faktor yang menciptakan suatu } \\
\text { proses belajar konsumen } \\
\text { berdasarkan pengalaman dari } \\
\text { lingkungannya. }\end{array}$ & $\begin{array}{l}\text { 1. Pengalaman } \\
\text { penggunaan } \\
\text { 2. Kesempatan mencoba } \\
\text { 3. Pengamatan } \\
\text { penggunaan oleh orang } \\
\text { lain }\end{array}$ & Skala Likert \\
\hline $\begin{array}{c}\text { Kepribadian } \\
\left(\mathrm{X}_{4}\right)\end{array}$ & $\begin{array}{l}\text { Suatu bentuk dari sifat-sifat } \\
\text { yang ada pada diri konsumen } \\
\text { yang sangat menentukan } \\
\text { perilaku yang terkontrol dan } \\
\text { sesuai dengan dengan tuntutan } \\
\text { lingkungan sehingga reaksinya } \\
\text { tidak merugikan konsumen. }\end{array}$ & $\begin{array}{l}\text { 1. Perilaku menunjukkan } \\
\text { konsistensi } \\
\text { 2. Perilaku membedakan } \\
\text { seseorang dengan yang } \\
\text { lainnya } \\
\text { 3. Perilaku berinteraksi } \\
\text { dengan situasi }\end{array}$ & Skala Likert \\
\hline $\begin{array}{c}\text { Keputusan } \\
\text { Membeli } \\
\text { (Y) }\end{array}$ & $\begin{array}{l}\text { Semua kegiatan, tindakan, serta } \\
\text { proses psikologis yang } \\
\text { mendorong tindakan tersebut } \\
\text { pada saat sebelum membeli, } \\
\text { ketika membeli, menggunakan, } \\
\text { menghabiskan produk dan jasa } \\
\text { serta kegiatan mengevaluasi. }\end{array}$ & $\begin{array}{l}\text { 1. Pengenalan Kebutuhan } \\
\text { 2. Pencarian Produk } \\
\text { 3. Evaluasi Alternatif } \\
\text { 4. Keputusan pembelian } \\
\text { 5. Perilaku pasca } \\
\quad \text { pembelian }\end{array}$ & Skala Likert \\
\hline
\end{tabular}




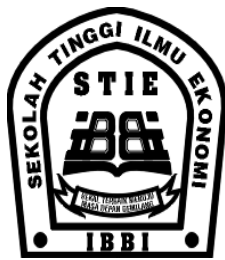

ISSN 1858-3199

JURNAL

MANAJEMEN BISNIS

STIE IBBI

\section{Model Analisis}

Alat uji statistik yang dipergunakan untuk menganalisis dalam penelitian ini adalah Analisis Regresi Linier Berganda (Multiple Regression Analysis) untuk menguji variabel bebas (motivasi, persepsi, pembelajaran, dan kepribadian) terhadap variabel terikat (keputusan membeli sepeda motor bekas).

\section{HASIL DAN PEMBAHASAN}

Populasi dan Sampel

Populasi dalam penelitian ini adalah seluruh konsumen yang telah melakukan Bea Balik Nama (BBN) sepeda motor bulan Januari sampai dengan Desember tahun 2012. Data diperoleh bahwa populasi masyarakat yang telah melakukan BBN sepeda motor di Kota Medan pada tahun 2012 berjumlah 117.857 orang.

Banyaknya sampel yang diambil dalam penelitian ini sebesar 400 konsumen sepeda motor (responden). Pembagian sampel berdasarkan jumlah responden di masing-masing kecamatan di Kota Medan dilakukan dengan teknik proportionate random sampling. Adapun distribusi populasi dan sampel pada masing-masing kecamatan di Kota Medan dapat dirinci sebagai berikut:

Tabel Distribusi Populasi dan Sampel Setiap Kecamatan di Kota Medan

\begin{tabular}{|c|c|c|c|c|}
\hline No. & Kecamatan & $\begin{array}{l}\text { Jumlah } \\
\text { Penduduk } \\
\text { (orang) }\end{array}$ & $\begin{array}{l}\text { Sampel } \\
\text { (orang) }\end{array}$ & \\
\hline 1 & Medan Tuntungan & 81.798 & $(81.798 / 2.053 .157) \times 400$ & $=16$ \\
\hline 2 & Medan Johor & 123.851 & $(123.851 / 2.053 .157) \times 400$ & $=24$ \\
\hline 3 & Medan Amplas & 111.771 & $(111.771 / 2.053 .157) \times 400$ & $=22$ \\
\hline 4 & Medan Denai & 141.866 & $(141.866 / 2.053 .157) \times 400$ & $=28$ \\
\hline 5 & Medan Area & 96.544 & $(96.544 / 2.053 .157) \times 400$ & $=19$ \\
\hline 6 & Medan Kota & 72.580 & $(72.580 / 2.053 .157) \times 400$ & $=14$ \\
\hline 7 & Medan Maimun & 39.581 & $(39.581 / 2.053 .157) \times 400$ & $=8$ \\
\hline 8 & Medan Polonia & 53.427 & $(53.427 / 2.053 .157) \times 400$ & $=10$ \\
\hline 9 & Medan Baru & 39.516 & $(39.516 / 2.053 .157) \times 400$ & $=$ \\
\hline 10 & Medan Selayang & 48.208 & $(48.208 / 2.053 .157) \times 400$ & $=9$ \\
\hline 11 & Medan Sunggal & 112.744 & $(112.744 / 2.053 .157) \times 400$ & $=22$ \\
\hline 12 & Medan Helvetia & 144.257 & $(144.257 / 2.053 .157) \times 400$ & $=28$ \\
\hline 13 & Medan Petisah & 67.057 & $(67.057 / 2.053 .157) \times 400$ & $=13$ \\
\hline 14 & Medan Barat & 70.771 & $(70.771 / 2.053 .157) \times 400$ & $=14$ \\
\hline 15 & Medan Timur & 108.633 & $(108.633 / 2.053 .157) \times 400$ & $=21$ \\
\hline 16 & Medan Perjuangan & 93.328 & $(93.328 / 2.053 .157) \times 400$ & $=18$ \\
\hline 17 & Medan Tembung & 133.579 & $(133.579 / 2.053 .157) \times 400$ & $=26$ \\
\hline 18 & Medan Deli & 166.793 & $(166.793 / 2.053 .157) \times 400$ & $=32$ \\
\hline 19 & Medan Labuhan & 111.173 & $(111.173 / 2.053 .157) \times 400$ & $=22$ \\
\hline 20 & Medan Marelan & 140.174 & $(140.174 / 2.053 .157) \times 400$ & $=27$ \\
\hline \multirow[t]{2}{*}{21} & Medan Belawan & 95.506 & $(95.506 / 2.053 .157) \times 400$ & $=19$ \\
\hline & 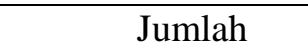 & 2.053 .157 & & 0 \\
\hline
\end{tabular}

Sumber: Badan Pusat Statistik, 2013 (Data Diolah) 


\section{Hasil Regresi Berganda}

Pengujian Hipotesis menyatakan bahwa motivasi, persepsi, pembelajaran, dan kepribadian berpengaruh terhadap keputusan membeli sepeda motor bekas.

Tabel Hasil Uji Koefisien Regresi Berganda

\begin{tabular}{|c|l|r|r|r|}
\hline \multirow{2}{*}{ Model } & & \multicolumn{2}{|c|}{$\begin{array}{c}\text { Unstandardized } \\
\text { Coefficients }\end{array}$} & $\begin{array}{c}\text { Standardized } \\
\text { Coefficients }\end{array}$ \\
\cline { 3 - 5 } & & \multicolumn{1}{|c|}{$\mathrm{B}$} & Std. Error & \multicolumn{1}{c|}{ Beta } \\
\hline \multirow{2}{*}{1} & (Constant) & 6.163 & .914 & \\
& Motivasi & .394 & .052 & .313 \\
& Persepsi & .360 & .052 & .274 \\
& Pembelajaran & .212 & .053 & .158 \\
& Kepribadian & .363 & .051 & .297 \\
\hline
\end{tabular}

a Dependent Variable: Keputusan_Pembelian

Sumber: Hasil Penelitian, 2013 (Data Diolah)

Berdasarkan pada tabel di atas, maka persamaan regresi berganda dalam penelitian adalah:

$\hat{Y}=6,163+0,394 X_{1}+0,360 X_{2}+0,212 X_{3}+0,363 X_{4}$

Pada persamaan tersebut dapat dilihat bahwa motivasi $\left(\mathrm{X}_{1}\right)$, persepsi $\left(\mathrm{X}_{2}\right)$, pembelajaran $\left(\mathrm{X}_{3}\right)$, dan kepribadian $\left(\mathrm{X}_{4}\right)$ memiliki kemampuan untuk mempengaruhi keputusan membeli sepeda motor bekas. Motivasi $\left(\mathrm{X}_{1}\right)$, persepsi $\left(\mathrm{X}_{2}\right)$, pembelajaran $\left(\mathrm{X}_{3}\right)$, dan kepribadian $\left(\mathrm{X}_{4}\right)$ mempunyai koefisien regresi positif yang membuktikan kontibusinya terhadap keputusan membeli sepeda motor bekas. Hal ini menunjukkan bahwa keputusan membeli sepeda motor bekas dapat dipengaruhi oleh motivasi $\left(\mathrm{X}_{1}\right)$, persepsi $\left(\mathrm{X}_{2}\right)$, pembelajaran $\left(\mathrm{X}_{3}\right)$, dan kepribadian $\left(\mathrm{X}_{4}\right)$.

\section{Koefisien Determinasi (R-Square)}

Nilai koefisien determinasi (R2) dipergunakan untuk mengukur besarnya pengaruh variabel bebas terhadap variabel terikat. Untuk mengetahui besarnya pengaruh variabel bebas terhadap variabel terikat pada regresi linier berganda digunakan nilai Adjusted $R$ Square pada tabel berikut:

\section{Tabel Koefisien Determinasi Hipotesis}

\begin{tabular}{|c|c|r|r|rr|}
\hline Model & $\mathrm{R}$ & $\mathrm{R}$ Square & Adjusted $\mathrm{R}$ Square & \multicolumn{2}{|c|}{$\begin{array}{c}\text { Std. Error of the } \\
\text { Estimate }\end{array}$} \\
\hline 1 & $.630^{\mathrm{a}}$ & .397 & .391 & .930 \\
\hline
\end{tabular}

a Predictors: (Constant), Kepribadian, Pembelajaran, Persepsi, Motivasi

b Dependent Variable: Keputusan_Pembelian

Sumber: Hasil Penelitian, 2013 (Data Diolah)

Berdasarkan tabel di atas diperoleh nilai Adjusted $\mathrm{R}$ Square sebesar 0,391. Hal ini menunjukan bahwa motivasi $\left(\mathrm{X}_{1}\right)$, persepsi $\left(\mathrm{X}_{2}\right)$, pembelajaran $\left(\mathrm{X}_{3}\right)$, dan kepribadian $\left(\mathrm{X}_{4}\right)$ memiliki kemampuan menjelaskan pengaruhnya terhadap variabel keputusan membeli sepeda motor bekas sebesar $39,1 \%$. Sisanya sebesar $60,9 \%$ merupakan pengaruh dari variabel bebas lain yang tidak diteliti dalam penelitian ini.

\section{Uji Secara Serempak}

Hasil pengujian Hipotesis secara serempak dapat dilihat pada tabel berikut: 


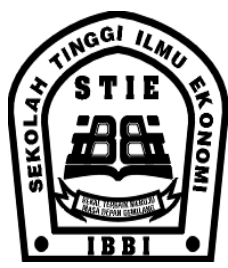

ISSN 1858-3199

JURNAL

MANAJEMEN BISNIS

STIE IBBI

Tabel Hasil Uji F

\begin{tabular}{|c|c|r|r|r|r|l|}
\hline Model & & Sum of Squares & \multicolumn{1}{c|}{$\mathrm{df}$} & $\begin{array}{c}\text { Mean } \\
\text { Square }\end{array}$ & F & Sig. \\
\hline \multirow{2}{*}{1} & Regression & 224.991 & 4 & 56.248 & 65.039 & $.000^{\mathrm{b}}$ \\
& Residual & 341.606 & 395 & .865 & & \\
\hline & Total & 566.598 & 399 & & & \\
\hline
\end{tabular}

a Predictors: (Constant), Kepribadian, Pembelajaran, Persepsi, Motivasi

b Dependent Variable: Keputusan_Pembelian

Sumber: Hasil Penelitian, 2013 (Data Diolah)

Berdasarkan tabel di atas diperoleh bahwa nilai $\mathrm{F}_{\text {hitung }}(65,039)$ lebih besar dibandingkan dengan nilai $F_{\text {tabel }}(2,31)$, dan sig. $\alpha\left(0,000^{\mathrm{a}}\right)$ lebih kecil dari alpha $5 \%(0,05)$. Hal ini mengindikasikan bahwa hasil penelitian menolak $\mathrm{H}_{0}$ dan menerima $\mathrm{H}_{1}$. Dengan demikian secara serempak motivasi $\left(\mathrm{X}_{1}\right)$, persepsi $\left(\mathrm{X}_{2}\right)$, pembelajaran $\left(\mathrm{X}_{3}\right)$, dan kepribadian $\left(\mathrm{X}_{4}\right)$ berpengaruh signifikan terhadap keputusan membeli sepeda motor bekas.

\section{Uji Secara Parsial}

Hasil pengujian hipotesis secara parsial dapat dilihat pada tabel berikut:

Tabel Hasil Uji Parsial

\begin{tabular}{|c|l|r|r|}
\hline \multicolumn{2}{|c|}{ Model } & $\mathrm{t}$ & \multicolumn{1}{c|}{ Sig. } \\
\hline 1 & (Constant) & 6.746 & .000 \\
& Motivasi & 7.565 & .000 \\
& Persepsi & 6.865 & .000 \\
& Pembelajaran & 4.015 & .000 \\
& Kepribadian & 7.111 & .000 \\
\hline
\end{tabular}

a Dependent Variable: Keputusan_Pembelian

Sumber: Hasil Penelitian, 2013 (Data Diolah)

Berdasarkan tabel di atas diperoleh hasil sebagai berikut:

1. Nilai $t_{\text {hitung }}$ untuk variabel motivasi $(7,565)$ lebih besar dibandingkan dengan nilai $t_{\text {tabel }}(1,986)$, atau nilai sig. $t$ untuk variabel motivasi $(0,000)$ lebih kecil dari alpha $(0,05)$.

Berdasarkan hasil yang diperoleh maka menolak $\mathrm{H}_{0}$ dan menerima $\mathrm{H}_{1}$ untuk variabel motivasi. Dengan demikian, secara parsial motivasi berpengaruh signifikan terhadap keputusan membeli pada Sepeda motor bekas.

2. Nilai $t_{\text {hitung }}$ untuk variabel persepsi $(6,865)$ lebih besar dibandingkan dengan nilai $t_{\text {tabel }}(1,986)$, atau nilai sig. $t$ untuk variabel persepsi $(0,000)$ lebih kecil dari alpha $(0,05)$.

Berdasarkan hasil yang diperoleh maka menolak $\mathrm{H}_{0}$ dan menerima $\mathrm{H}_{1}$ untuk variabel persepsi. Dengan demikian, secara parsial persepsi berpengaruh signifikan terhadap keputusan membeli pada Sepeda motor bekas.

3. Nilai $t_{\text {hitung }}$ untuk variabel pembelajaran $(4,015)$ lebih besar dibandingkan dengan nilai $t_{\text {tabel }}$ $(1,986)$, atau nilai sig. $t$ untuk variabel pembelajaran $(0,000)$ lebih kecil dari alpha $(0,05)$.

Berdasarkan hasil yang diperoleh maka menolak $\mathrm{H}_{0}$ dan menerima $\mathrm{H}_{1}$ untuk variabel pembelajaran. Dengan demikian, secara parsial pembelajaran berpengaruh signifikan terhadap keputusan membeli pada Sepeda motor bekas. 


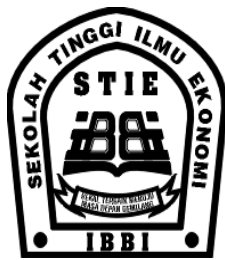

ISSN 1858-3199

JURNAL

MANAJEMEN BISNIS

STIE IBBI

4. Nilai $t_{\text {hitung }}$ untuk variabel kepribadian $(7,111)$ lebih besar dibandingkan dengan nilai $t_{\text {tabel }}$ $(1,986)$, atau nilai sig. $t$ untuk variabel kepribadian $(0,000)$ lebih kecil dari alpha $(0,05)$.

Berdasarkan hasil yang diperoleh maka menolak $\mathrm{H}_{0}$ dan menerima $\mathrm{H}_{1}$ untuk variabel kepribadian. Dengan demikian, secara parsial kepribadian berpengaruh signifikan terhadap keputusan membeli pada Sepeda motor bekas.

Secara parsial variabel motivasi berpengaruh lebih dominan daripada variabel persepsi, pembelajaran, dan kepribadian. Artinya, variabel motivasi lebih berperan dalam menentukan keputusan membeli sepeda motor bekas dibandingkan dengan variabel lainnya.

\section{KESIMPULAN DAN SARAN Kesimpulan}

Berdasarkan hasil penelitian dan pembahasan yang telah di uraikan pada bab sebelumnya, disimpulkan bahwa secara serempak motivasi, persepsi, pembelajaran, dan kepribadian berpengaruh signifikan terhadap keputusan membeli sepeda motor bekas. Hal ini menunjukkan bahwa keputusan membeli sepeda motor bekas dapat dipengaruhi oleh motivasi, persepsi, pembelajaran, dan kepribadian. Sedangkan secara parsial variabel motivasi berpengaruh lebih dominan daripada variabel persepsi, pembelajaran, dan kepribadian. Artinya, variabel motivasi lebih berperan dalam menentukan keputusan membeli sepeda motor bekas dibandingkan dengan variabel lainnya.

\section{Saran}

Berdasarkan kesimpulan, motivasi memiliki pengaruh dominan dalam menentukan keputusan membeli sepeda motor bekas. Maka, ada baiknya pelaku usaha sepeda motor bekas memperhatikan motivasi apa yang melatarbelakangi konsumen dalam melakukan pembelian sepeda motor bekas. Beberapa hal yang perlu mendapat perhatian dalam variabel ini adalah tentang kondisi sepeda motor bekas yang ditawarkan. Semakin baik kondisi kendaraan yang dijual akan meningkatkan motivasi konsumen dalam menentukan pembeliannya. Selain itu, pelaku usaha memperhatikan kebutuhan kendaraan setiap konsumennya. Dengan mengetahui inan konsumen diharapkan pelaku usaha dapat memberikan rekomendasi sepeda motor yc suai dengan kebutuhan konsumen tersebut.

\section{DAFTAR PUSTAKA}

Arikunto, Suharsimi. 2006. Prosedur Penelitian: Suatu Pendekatan Praktek. Edisi Revisi. Jakarta: PT Rineka Cipta.

Ghozali, Imam. 2005. Aplikasi Analisis Multivariate dengan Program SPSS. Semarang: Badan Penerbit Salemba Empat.

Kotler, Philip dan Keller, Kevin Lane. 2007. Manajemen Pemasaran. Edisi Kedua Belas. Edisi Bahasa Indonesia. Jakarta: Penerbit PT Indeks.

Kotler, Philip dan Amstrong. 2001. Prinsip-prinsip Pemasaran. Jidil I. Edisi Kedelapan. Terjemahan: Damos Sihombing. Jakarta: Penerbit Erlangga.

Kuncoro, Mudrajat. 2003. Metode Riset Bisnis da Ekonomi: Bagaimana Meneliti dan Menulis Tesis. Jakarta: Penerbit Erlangga.

Mangkunegara, A.A. Anwar Prabu. 2005. Perilaku Konsumen. Cetakan Ketiga. Edisi Revisi. Bandung: Penerbit PT Refika Aditama.

Mowen, John C. dan Michael Minor. 2002. Perilaku Konsumen. Jilid I. Edisi Kelima. Jakarta: Erlangga. 
Nasir, Moh. 2005. Metode Penelitian. Cetakan Keenam. Bogor: Penerbit Ghalia Indonesia.

Priyatno, Duwi. 2012. Cara Kilat Belajar Analisis Data dengan SPSS 20. Edisi I. Yogyakarta: Andi.

Schiffman, Leon dan Kanuk, Leslie Lazar. 2007. Perilaku Konsumen. Edisi Ketujuh. Jakarta: Penerbit PT Indeks.

Setiadi, J. Nugroho. 2003. Perilaku Konsumen. Jakarta: Penerbit Prenada Media.

Singarimbun, Masri dan Sofian Effendi. 2006. Metode Penelitian Survai. Cetakan Kedelapanbelas. Edisi Revisi. Jakarta: PT Pustaka LP3ES Indonesia.

Simamora, Bilson. 2003. Membongkar Kotak Hitam Konsumen. Jakarta: Penerbit PT. Gramedia Pustaka Utama.

Sugiyono. 2005. Metode Penelitian Bisnis. Bandung: Penerbit Alfabeta.

Sumarwan, Ujang. 2004. Perilaku Konsumen: Teori dan Penerapannya dalam Pemasaran. Bogor: Ghalia Indonesia.

Sunarto. 2004. Prinsip-prinsip Pemasaran. Cetakan Pertama. Edisi Kedua. Yogyakarta: Penerbit Amus danan UST Press.

Wilkie, William L. 1986. Consumer Behaviour. New York: John Wiley and Sons Inc.

Umar, Husein. 2008. Metode Penelitian Untuk Skripsi Dan Tesis Bisnis. Edisi Kedua. Jakarta: PT. RajaGrafindo Persada.

Ulfah, Gumala. 2010. Analisis Faktor-faktor Internal yang Mempengaruhi Keputusan Konsumen Membeli Mobil Bekas di Kota Medan. Tesis. Universitas Sumatera Utara. (Tidak Dipublikasikan).

http://www.pemkomedan.go.id/news_detail.php?id=3805, 5 Juni 2010, 13.00 wib.

www.medankota.bps.go.id, 8 Juni 2010, 14.00 wib. 


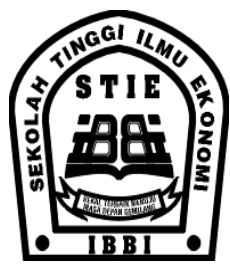

ISSN 1858-3199

JURNAL

MANAJEMEN BISNIS

STIE IBBI

\title{
ANALISIS FAKTOR-FAKTOR YANG MEMPENGARUHI MINAT KEWIRAUSAHAAN MAHASISWA S-1 PERGURUAN TINGGI NEGERI DI MEDAN
}

\author{
Junaidi Hasan, SE., MM \\ Drs. Syafri Fadillah Marpaung,
}

\begin{abstract}
ABSTRAK
Dampak dari pertambahan penduduk adalah tingginya tingkat pengangguran karena pertambahan jumlah tenaga kerja yang lebih besar dibandingkan jumlah lapangan kerja yang tersedia, dan saat ini terdapat 22.671 orang sarjana di Sumatera Utara yang terdata tidak memiliki pekerjaan. Mata Kuliah Kewirausahaan diajarkan kepada mahasiswa dengan harapan mahasiswa akan tertarik untuk menjadi wirausaha selama atau setelah menyelesaikan kuliahnya sehingga mereka bisa menciptakan lapangan pekerjaan bagi diri sendiri dan masyarakat.

Tujuan penelitian ini adalah untuk mengetahui dan menganalisis pengaruh variabel kepribadian, lingkungan dan demografis terhadap variabel minat kewirausahaan mahasiswa Strata-1 Perguruan Tinggi Negeri di Medan, untuk mengetahui dan menganalisis pengaruh variabel kebutuhan akan prestasi dan efikasi diri terhadap variabel kepribadian pada mahasiswa Strata-1 Perguruan Tinggi Negeri di Medan dan untuk mengetahui dan menganalisis pengaruh variabel ketersediaan informasi kewirausahaan, akses kepada modal dan kepemilikan jaringan sosial terhadap variabel lingkungan mahasiswa Strata-1 Perguruan Tinggi Negeri di Medan. Populasi dalam penelitian ini berjumlah 55.948 orang dengan jumlah sampel sebanyak 200 orang responden. Data dianalisis menggunakan analisis jalur (path analysis).

Variabel kepribadian, lingkungan, demografis secara serempak berpengaruh sangat signifikan terhadap variabel minat kewirausahaan. variabel kepribadian, lingkungan, demografis secara serempak mampu menjelaskan variabel minat kewirausahaan sebesar $18 \%$. Variabel kebutuhan akan prestasi, efikasi diri secara serempak berpengaruh sangat signifikan terhadap variabel kepribadian. variabel efikasi diri dan kebutuhan akan prestasi secara serempak mampu menjelaskan variabel kepribadian sebesar $-7 \%$. Variabel ketersediaan informasi kewirausahaan, kepemilikan jaringan sosial dan akses kepada modal secara serempak berpengaruh sangat signifikan terhadap variabel lingkungan. Variabel ketersediaan informasi kewirausahaan, kepemilikan jaringan sosial dan akses kepada modal secara serempak mampu menjelaskan variabel lingkungan sebesar 77,3\%. Korelasi antara variabel kebutuhan berprestasi dengan efikasi diri sebesar 0,380. korelasi antara variabel kebutuhan informasi dengan Jaringan social sebesar 0,551. korelasi antara variabel kebutuhan informasi dengan Akses sebesar 0,451. korelasi antara variabel Jaringan social dengan Akses sebesar 0,613. korelasi antara variabel Demografi dengan Kepribadian sebesar 0,209. korelasi antara variabel Demografi dengan Lingkungan sebesar 0,206. korelasi antara variabel Kepribadian dengan Lingkungan sebesar 0,163. Nilai korelasi yang positif menunjukkan bahwa semakin besar kebutuhan berprestasi maka akan semakin besar pula efikasi diri.

Disarankan kepada pihak universitas diharapkan dapat menciptakan program yang dapat menumbuhkan kepribadian dan lingkungan kampus yang positif untuk mendukung tumbuhnya minat kewirausahaan mahasiswa.
\end{abstract}

Keyword : Kepribadian, Lingkungan, Demografis, Minat Kewirausahaan 


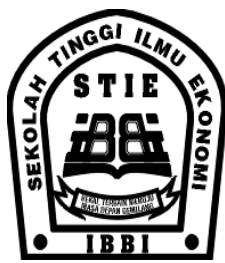

ISSN 1858-3199

JURNAL

MANAJEMEN BISNIS

STIE IBBI

\section{Pendahuluan}

Pertumbuhan penduduk yang terus bertambah setiap tahunnya menimbulkan sebuah permasalahan dalam menyediakan lapangan kerja. Dampak yang ditimbulkan adalah tingginya tingkat pengangguran karena pertambahan jumlah tenaga kerja yang lebih besar dibandingkan jumlah lapangan kerja yang tersedia.

Permasalahan yang dihadapi dalam bidang ketenagakerjaan bahwa saat ini terdapat sebanyak 22.671 orang sarjana di Sumatera Utara yang terdata tidak memiliki pekerjaan. Hal ini dibenarkan Kepala Seksi Penempatan Tenaga Kerja Dinas Tenaga Kerja Sumatera Utara, Raswin Siallagan, yang mengatakan " Jika dibandingkan dengan tahun 2011, jumlah pengangguran tahun 2012 meningkat sebanyak 402.125 orang. "Masih banyak yang tidak memiliki pekerjaan, mulai dari tingkat pendidikan SMP, SMA, hingga sarjana. Pendataan terakhir, 22.671 orang bertitel sarjana menganggur sementara yang tamatan diploma mencapai 13.960 orang, dan 35.908 tamatan SMTA atau kejuruan. (Harian Analisa Rabu, 09 Jan 2013).

Mata kuliah kewirausahaan diajarkan kepada mahasiswa dengan harapan mahasiswa akan tertarik untuk menjadi wirausaha selama atau setelah menyelesaikan kuliahnya sehingga mereka bisa menciptakan lapangan pekerjaan bagi diri sendiri dan masyarakat.

Berdasarkan uraian di atas maka perlu diteliti variabel-variabel yang dominan mempengaruhi minat para mahasiswa terhadap kewirausahaan sehingga dapat dikembangkan program dan kurikulum yang sesuai agar dapat menciptakan banyak wirausaha dari masing-masing Perguruan Tinggi Negeri Di Medan .

\section{Tinjauan Pustaka}

\section{Teori tentang Kepribadian}

Kepribadian yang melekat dalam diri masing-masing individu sifatnya dapat berubah-ubah atau stabil dari waktu ke waktu. Kepribadian bersifat unik dan konsisten sehingga dapat digunakan untuk membedakan antara individu yang satu dengan individu lainnya. Demikian pula halnya dengan seorang wirausaha memiliki karakteristik yang berbeda-beda, akan tetapi seorang wirausaha yang sukses memiliki karakteristik kepribadian yang khusus sehingga hal inilah yang membedakan darinya dengan orang lain.

Harris dalam Suryana (2006) mengatakan bahwa seorang wirausaha yang sukses pada umumnya adalah mereka yang memiliki kompetensi khusus antara lain adalah memiliki ilmu pengetahuan, keterampilan dan kualitas individu yang meliputi sikap, motivasi, nilai-nilai pribadi serta tingkah laku yang diperlukan dalam bekerja. Untuk mengetahui faktor yang dapat mempengaruhi keberhasilan seseorang dalam menjalankan sebuah usaha dibutuhkan kepribadian yang mendukung, Hal ini sesuai dengan penelitian yang dilakukan oleh Mazzarol et al. dalam Saud et al. (2009) yang menemukan bahwa faktor kepribadian yang terdiri dari sikap pribadi dan latar belakang responden memiliki pengaruh dalam mendorong untuk mendirikan sebuah usaha.

\subsection{Kebutuhan Akan Prestasi}

McClelland dalam Indiarti ad. All (2008) Kebutuhan akan prestasi dapat diartikan sebagai suatu kesatuan watak yang memotivasi seseorang untuk menghadapi tantangan untuk mencapai kesuksesan dan keunggulan. Lebih lanjut, McClelland menegaskan bahwa kebutuhan akan prestasi sebagai salah satu karakteristik kepribadian seseorang yang akan mendorong seseorang untuk memiliki keinginan berwirausaha.

Sengupta dan Debnath dalam Indarti et al. (2008) dalam penelitian yang dilakukan Di India menemukan bukti bahwa kebutuhan akan prestasi berpengaruh besar dalam tingkat kesuksesan seorang wirausaha. Lebih spesifik, kebutuhan akan prestasi juga dapat mendorong kemampuan 


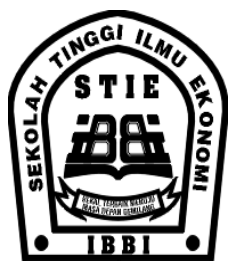

ISSN 1858-3199

JURNAL

MANAJEMEN BISNIS

STIE IBBI

pengambilan keputusan dan kecenderungan untuk mengambil resiko seorang berwirausaha. Semakin tinggi kebutuhan akan prestasi seorang wirausaha, semakin banyak keputusan tepat yang akan diambil.

Prestasi yang tinggi dari seseorang dapat dilihat dari ciri-ciri yang dimiliki. Faisol dalam Mudjiarto (2006:28) menyatakan bahwa orang-orang yang berprestasi tinggi mempunyai ciri-ciri : Berani mengambil resiko, Kreatif dan inovatif, Memiliki visi dan tujuan yang berkelanjutan, Percaya diri, Mandiri, Aktif, enerjik dan menghargai waktu, Memiliki konsep diri yang positif, Berpikir positif, Bertanggung jawab secara pribadi, Selalu belajar dan menggunakan umpan balik.

\subsection{Efikasi Diri}

Efikasi diri merupakan sebuah keyakinan seseorang terhadap kemampuan dirinya untuk melakukan sesuatu pekerjaan dan mendapatkan prestasi tertentu. Efikasi diri akan menentukan cara seseorang untuk berpikir, bertindak dan memotivasi diri mereka menghadapi kesulitan dan permasalahan. Sukses atau tidaknya seseorang dalam melakukan sebuah tugas ditentukan oleh efikasi dirinya. Orang yang memiliki efikasi diri yang tinggi akan dapat menghadapi kegagalan dan hambatan yang mereka hadapi, stabil emosinya, bersikap dan memiliki internal locus of control yang tinggi. Cromie dalam Indarti et al. (2008) menjelaskan bahwa efikasi diri mempengaruhi kepercayaan seseorang dalam mencapai sebuah tujuan yang sudah ditetapkan. Lebih lanjut Cromie juga menyatakan bahwa efikasi diri yang positif merupakan sebuah keyakinan yang dimiliki seseorang bahwa ia mampu meraih prestasi yang diinginkannya dalam pekerjaan. Betz dan Hacket dalam Indarti et al. (2008) menyatakan bahwa efikasi diri akan karir seseorang dapat menjadi faktor penting dalam penentuan apakah minat kewirausahaan seseorang sudah terbentuk pada tahapan awal seseorang memulai karirnya. Lebih lanjut Betz dan Hacket menyatakan bahwa semakin tinggi tingkat efikasi diri seseorang pada kewirausahaan di masa-masa awal seseorang dalam berkarir, maka akan semakin kuat minat kewirausahaan yang akan dimilikinya. Wirausaha yang sukses akan selalu yakin bahwa mereka mampu merencanakan dan dapat membuat semua kegiatan yang dilakukannya menjadi berhasil. Mereka yang sukses juga mampu mengendalikan kesuksesannya tanpa memiliki ketergantungan yang tinggi terhadap orang lain.

\section{Teori tentang Lingkungan}

Minat seseorang terhadap suatu obyek diawali dari perhatian seseorang terhadap obyek tersebut. Minat tidak dibawa sejak lahir, melainkan tumbuh dan berkembang sesuai dengan faktorfaktor yang mempengaruhinya. Minat dapat berubah-ubah tergantung dari faktor-faktor yang mempengaruhinya di antaranya adalah faktor lingkungan. Menurut Lupiyoadi (2007: 12) faktor lingkungan yang mempengaruhi minat meliputi lingkungan keluarga, lingkungan pendidikan dan lingkungan masyarakat.

Faktor lingkungan yang mempengaruhi kesuksesan sebuah wirausaha yang dilakukan menurut Indarti et al. (2008) terdapat tiga faktor yaitu : Ketersediaan informasi, Akses kepada modal, Kepemilikan jaringan sosial.

Dari berbagai pendapat para ahli yang telah disampaikan di atas maka dapat disimpulkan bahwa minat kewirausahaan secara garis besar dipengaruhi oleh dua faktor yaitu faktor internal dan faktor eksternal. Faktor internal merupakan faktor yang timbul karena adanya pengaruh dari dalam diri individu itu sendiri seperti kebutuhan akan pendapatan, harga diri, perasaan senang, dan lainlain. Sedangkan Faktor eksternal merupakan faktor yang mempengaruhi individu karena adanya pengaruh dari sekelilingnya atau berasal dari luar dirinya sendiri yang meliputi lingkungan keluarga, lingkungan masyarakat, lingkungan internasional, perubahan teknologi, kondisi ekonomi, budaya dan sosial. 


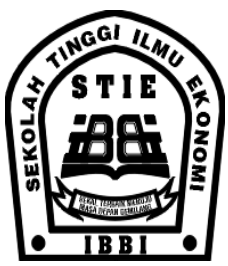

ISSN 1858-3199

JURNAL

MANAJEMEN BISNIS

STIE IBBI

Berdasarkan teori dan hasil penelitian yang telah dijelaskan di atas, maka dapat disimpulkan bahwa pengertian lingkungan dalam penelitian ini adalah faktor luar/eksternal yang menimbulkan dan mendorong minat kewirausahaan seseorang yang meliputi kepemilikan jaringan sosial, akses kepada modal dan ketersediaan informasi kewirausahaan.

\subsection{Ketersediaan Informasi Kewirausahaan}

Informasi merupakan data yang telah dibentuk ke dalam sebuah format yang dapat bermanfaat bagi manusia. Informasi mempunyai peranan yang sangat penting di dalam menjalankan kewirausahaan sebagaimana pentingnya informasi dalam bidang-bidang lainnya.

Minat menjadi seorang wirausaha akan muncul dan berkembang dengan bertahap apabila tersedianya informasi yang memadai yaitu tentang keberhasilan sebuah usaha, peluang usaha yang tersedia, pasar yang mampu diraih, adanya dukungan pemerintah dan badan-badan yang berhubungan dengan kewirausahaan, serta adanya dukungan dari perguruan tinggi dalam melaksanakan pelatihan dan pendidikan yang berhubungan dengan menciptakan jiwa kewirausahaan.

Berdasarkan teori dan hasil penelitian yang telah dijelaskan di atas, maka dapat disimpulkan bahwa pengertian ketersediaan informasi kewirausahaan dalam penelitian ini adalah tersedianya informasi yang dibutuhkan dan mendukung kegiatan kewirausahaan secara memadai.

\subsection{Akses Kepada Modal}

Dalam menjalankan sebuah usaha salah satu faktor yang sangat penting dan harus dimiliki adalah modal. Dari beberapa Penelitian yang dilakukan oleh beberapa peneliti seperti Marsden, Meier dan Pilgrim, Steel dalam Indarti et al. (2008) menyatakan bahwa hambatan yang utama yang dimiliki oleh calon-calon wirausaha di negara berkembang adalah sulitnya mendapatkan akses modal, skema kredit dan kendala sistem keuangan. Hal ini sejalan dengan pendapat Kristiansen dalam Indarti et al. (2008) yang menyatakan bahwa akses kepada modal menjadi salah satu faktor dalam menentukan kesuksesan suatu usaha. Sedangkan menurut Indarti et al. (2008) menyatakan bahwa akses kepada modal merupakan hambatan klasik yang dimiliki seseorang dalam memulai sebuah usaha baru, terutama di negara-negara yang sedang berkembang, hal ini disebabkan karena lemahnya dukungan yang diperoleh dari lembaga-lembaga penyedia keuangan.

Sedangkan Manurung (2008:13) menyatakan bahwa modal usaha merupakan dana yang digunakan untuk dapat menjalankan kegiatan sebuah usaha. selanjutnya Manurung juga menyatakan bahwa ada beberapa cara dalam memperoleh sumber modal, yaitu: Dana milik sendiri, Menggadaikan barang yang dimiliki ke lembaga formal atau non-formal, Meminjam dari lembaga formal atau non-formal, Menggunakan modal dari pemasok, Bermitra dengan mitra kerja agar modal kerja yang dibutuhkan dapat dibagi bersama, Melakukan pinjaman dari bank, Mendapatkan modal dari pasar modal dengan menerbitkan obligasi, saham, dan lain-lain, Mendapatkan bantuan dari pemerintah, perusahaan baik swasta maupun BUMN, universitas, dan lain-lain.

Akses kepada modal dalam penelitian ini adalah kemampuan wirausaha untuk mendapatkan modal untuk menjalankan usahanya.

\subsection{Kepemilikan Jaringan Sosial}

Mazzarol dalam Indarti et al. (2008) menyatakan bahwa jaringan sosial dapat mempengaruhi minat kewirausahaan. Gregoire et al. dalam Gadar dan Yunus (2009) juga menyatakan bahwa jaringan sosial merupakan faktor yang paling berpengaruh pada wirausaha wanita. Penelitian oleh Gadar dan Yunus (2009) menemukan bahwa jaringan sosial merupakan faktor terpenting yang kelima pada wirausaha yang dilakukan oleh wanita di Malaysia. Selain itu Gadar dan Yunus juga menemukan bahwa hubungan dengan elit politik yang kuat dan dengan 

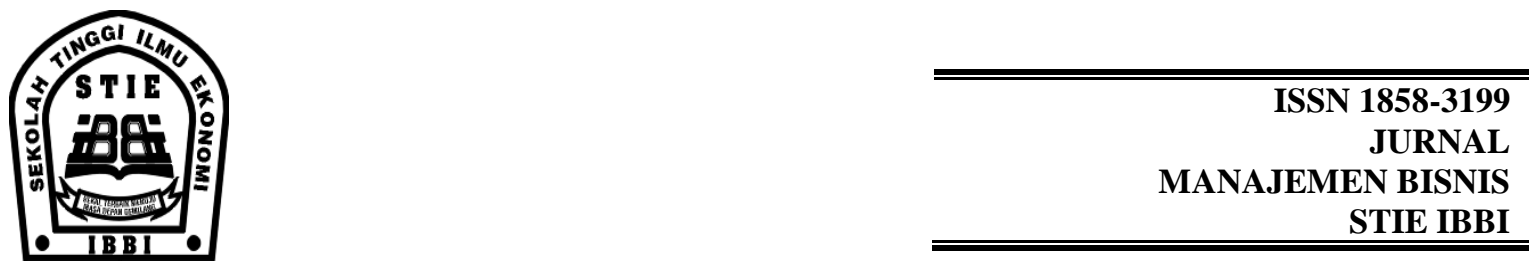

pemimpin bisnis, dukungan suami juga merupakan faktor yang sangat mendukung para wirausaha yang dilakukan oleh wanita di Malaysia.

Pendapat lain disampaikan oleh Kristiansen dalam Indarti et al. (2008) yang menjelaskan bahwa jaringan sosial terdiri dari hubungan formal dan informal antara pelaku utama dan pendukung dalam sebuah lingkaran terkait dan menggambarkan sebuah jalur bagi wirausaha untuk mendapatkan akses kepada sumber daya yang dibutuhkan dalam mendirikan, mengembangkan dan mensukseskan sebuah usaha.

\section{Teori tentang Demografi}

Kata demografi berasal dari bahasa Yunani yaitu demos. yang berarti rakyat atau penduduk dan .grafein. yaitu menulis. Sehingga demografi merupakan tulisan atau karangan mengenai rakyat atau penduduk. Barclay dalam Yasin (2007: 2) menyatakan bahwa demografi merupakan sebuah ilmu yang memberikan gambaran yang menarik tentang penduduk yang digambarkan secara statistika. Demografi juga mempelajari tingkah laku secara keseluruhan dan bukan tingkah laku perorangan. Mazzarol dalam Indarti et al. (2008) yang menyatakan bahwa faktor-faktor demografi seperti jender, umur, pendidikan dan pengalaman bekerja seseorang berpengaruh terhadap keinginan seseorang untuk menjadi seorang wirausaha.

Crant dalam Saud et al. (2009) menyatakan bahwa sikap kewirausahaan dipengaruhi oleh jender, tingkat pendidikan dan orang tua yang memiliki bisnis. Penelitian oleh Mazzarol et al. dalam Saud et al. (2009) juga menemukan bahwa faktor demografi (etnisitas, status perkawinan, tingkat pendidikan, ukuran keluarga, status dan pengalaman kerja, usia, jender, status sosioekonomi, agama dan sifat kepribadian) mempengaruhi minat mendirikan usaha. Sedangkan pendapat Shapero dalam Basu et al. (2009) menyatakan bahwa minat terhadap kewirausahaan tergantung pada faktor-faktor eksogen seperti demografi, karakter, keterampilan, budaya, sosial dan dukungan keuangan.

Hisrich (2008:75) menyatakan bahwa pendidikan sangatlah penting dalam menjalankan wirausaha. Pentingnya pendidikan tidak hanya tercermin dalam tingkat pendidikan yang dicapai, akan tetapi pendidikan juga memainkan sebuah peranan penting dalam membantu para wirausaha mengatasi berbagai permasalahan yang mereka hadapi.

Bandura, Hollenbeck dan Hall, Wilson et al. dalam Basu et al. (2009) menemukan bahwa dengan diberikannya pendidikan kewirausahaan maka akan dapat meningkatkan tingkat efikasi diri seseorang. Noel dalam Basu et al. (2009) menemukan bahwa pendidikan kewirausahaan memiliki hubungan yang sangat kuat dengan minat kewirausahaan terutama untuk mahasiswi. Wilson et al. dalam Basu et al. (2009) menyatakan bahwa pendidikan kewirausahaan mampu meningkatkan minat mahasiswa terhadap kewirausahaan sebagai karier.

\section{Teori tentang Minat Kewirausahaan}

Menurut Slameto (2013:180), mengartikan minat sebagai suatu rasa lebih suka dan rasa dan keterkaitan pada suatu hal atau aktivitas tanpa ada yang menyuruh. Ketika kepuasan menurun maka minatnya juga akan menurun sehingga minat tidak bersifat permanen, tetapi bersifat sementara atau dapat berubah-ubah.

Kewirausahaan atau entrepreneurship berasal dari bahasa Perancis "entreprende" yang artinya to undertake yaitu menjalankan, melakukan dan berusaha. Dalam Bahasa Indonesia kata entrepreneur diartikan sebagai wirausaha yang merupakan gabungan dari dua kata yaitu kata wira yang artinya gagah berani, perkasa dan usaha. Jadi wirausaha berarti orang yang gagah berani atau perkasa dalam usaha. 


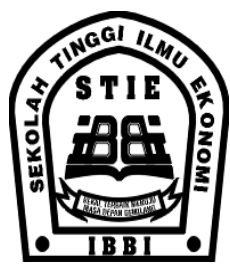

ISSN 1858-3199

JURNAL

MANAJEMEN BISNIS

STIE IBBI

Yuwono (2008) menyatakan bahwa minat kewirausahaan merupakan rasa ketertarikan yang dimiliki oleh seseorang untuk dapat melakukan kegiatan usaha yang mandiri dengan keberanian mengambil resiko. Steinhoff dan Burgess dalam Suryana (2006) menyatakan bahwa ada tujuh alasan mengapa seseorang berminat terhadap kegiatan kewirausahaan, yaitu:

1. Ingin memiliki penghasilan yang tinggi.

2. Ingin memiliki karier yang memuaskan.

3. Ingin bisa mengarahkan diri sendiri/tidak diatur oleh orang lain.

4. Ingin meningkatkan prestise diri sebagai pemilik bisnis.

5. Ingin menjalankan ide atau konsep yang dimiliki secara bebas.

6. Ingin memiliki kesejahteraan hidup dalam jangka panjang.

7. Ingin menyumbangkan sesuatu yang bermanfaat bagi kemanusiaan.

Dalam penelitian ini yang dimaksudkan dengan minat kewirausahaan adalah kecenderungan atau ketertarikan seseorang untuk melakukan kegiatan kewirausahaan dengan senang hati dan dengan keberanian mengambil resiko.

\section{Metode Penelitian}

Penelitian ini dilakukan di Medan - Sumatera Utara, dilaksanakan mulai Bulan April 2013 Desember 2013. Jenis penelitian yang dilakukan adalah survei. Sedangkan jenis penelitian berdasarkan jenis data dan analisis adalah penelitian kuantitatif. Populasi penelitian ini adalah seluruh mahasiswa strata-1 Perguruan Tinggi Negeri Di Medan Tahun 2011-2012 yang berjumlah 55,948, yang terdiri dari 36.926 Mahasiswa USU dan 19.024 mahasiswa UNIMED. Sampel yang digunakan dalam mewakili populasi yang ada sebanyak 200 orang, 100 orang responden dari USU dan 100 orang responden dari UNIMED.

Metode pengumpulan data dalam penelitian ini adalah:

a. Wawancara (interview) yang dilakukan kepada beberapa Pembantu Rektor III Di beberapa Perguruan Tinggi Negeri Di Medan atau pihak-pihak yang ditunjuk.

b. Daftar pertanyaan (questionaire) yang diberikan kepada responden penelitian.

c. Studi dokumentasi dengan mempelajari data-data yang tentang Perguruan Tinggi Negeri Di Medan dan websitenya.

Jenis dan sumber data dalam penelitian ini adalah data primer yaitu data yang diperoleh secara langsung dari sumbernya yaitu melalui daftar pertanyaan dan wawancara dan data sekunder yaitu yang diperoleh dari studi dokumentasi berupa dokumen-dokumen resmi yang diterbitkan oleh Perguruan Tinggi Negeri Di Medan dan dari website berhubungan dengan data yang dibutuhkan.

Metode analisis data yang digunakan dalam penelitian ini adalah analisis jalur (path analysis). Karena ada beberapa hipotesis dalam penelitian ini, maka masing-masing hipotesis akan memiliki satu persamaan model struktural. Masing-masing hipotesis akan digambarkan pada satu model diagram jalur tersendiri.

Uji validitas dan reliabilitas instrumen dalam penelitian ini dilakukan terhadap 30 orang mahasiswa strata-1 di luar responden yang dijadikan sampel penelitian. Uji validitas dilakukan dengan membandingkan nilai correlated item - total correlation pada setiap butir pertanyaan terhadap nilai $\mathrm{r}$ variabel. Sunyoto (2009: 72) menyatakan jika nilai correlated item - total correlation rhitung > nilai rtabel dan nilainya positif, maka butir pertanyaan pada setiap variabel penelitian dinyatakan valid.

Penelitian ini menggunakan metode one shot di mana kuesioner diberikan hanya sekali saja kepada responden dan kemudian hasilnya dibandingkan dengan pertanyaan lain untuk mengukur korelasi antarjawaban pertanyaan. Pengukuran reliabilitasnya menggunakan uji statistik Cronbach 


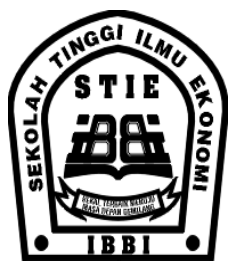

ISSN 1858-3199

JURNAL

MANAJEMEN BISNIS

STIE IBBI

Alpha. Menurut Sunyoto (2009: 68) suatu konstruk dikatakan reliabel jika memberikan nilai Cronbach Alpha > 0,60. Pengujian validitas dan reliabilitas dilakukan dengan bantuan perangkat lunak pengolahan data Statistical Package for Social Sciences (SPSS).

Sunyoto (2009:89) menyatakan bahwa untuk menguji normalitas dapat dilakukan dengan cara membuat normal probability plot yang membandingkan data riil dengan data distribusi normal secara kumulatif. Suatu data dikatakan mempunyai distribusi normal jika garis riil mengikuti garis diagonal. Untuk mendeteksi adanya multikolinearitas dapat dilihat dari nilai tolerance dan variance inflation factor (VIF), jika nilai tolerance $<0,10$ dan nilai VIF $>10$ maka terjadi multikolinearitas dan sebaliknya jika nilai tolerance $>0,10$ dan nilai $\mathrm{VIF}<10$, maka dikatakan tidak terjadi multikolinearitas.

Uji heteroskedastisitas dipakai untuk menguji sama atau tidaknya varians dari residual observasi yang satu dengan observasi yang lain. Persamaan yang baik adalah jika tidak terjadi heteroskedastisitas. Dalam melakukan uji normalitas, multikolinearitas dan heterokedastisitas dilakukan dengan bantuan SPSS.

\section{Hasil Penelitian dan Pembahasan Karakteristik Responden}

Karakteristik responden dari data yang diperoleh dalam penelitian ini menunjukkan bahwa, usia responden mulai dari 19 tahun sampai usia 24 tahun. Berdasarkan usia mayoritas responden berusia 22 tahun (39\%). Karakteristik responden berdasarkan jenis kelamin dari data yang diperoleh menunjukkan bahwa lebih banyak pria (66\%) yang berminat menjadi atau sudah menjalankan wirausaha dibandingkan wanita (34\%).

Berdasarkan pendidikan kewirausahaan menunjukkan bahwa 39\% responden sudah pernah mendapatkan pengetahuan melalui mata kuliah pendidikan kewirausahaan di kampus dan $61 \%$ belum pernah mendapatkan mata kuliah pendidikan kewirausahaan di kampus. Sedangkan responden yang sudah pernah mengikuti kegiatan pada seminar-seminar kewirausahaan sebanyak $59 \%$ dan $41 \%$ dari responden belum pernah mengikuti kegiatan-kegiatan seminar kewirausahaan.

Berdasarkan pengalaman kerja yang dimiliki sebelum memulai kegiatan kewirausahaan, bahwa terdapat 59\% dari responden tidak memiliki pengalaman kerja sebelum melakukan kegiatan kewirausahaan, dan $41 \%$ dari responden sudah memiliki pengalaman kerja sebelumnya.

\section{Hasil Uji Validitas dan Reliabilitas}

Hasil uji validitas terhadap 44 butir pernyataan dari variabel yang diteliti seluruhnya dinyatakan valid karena nilai corrected item total correlation $>0,3$ dan selanjutnya akan digunakan dalam pengujian berikutnya.

Hasil uji reliabilitas terhadap 9 variabel yang diteliti seluruhnya dinyatakan reliabel karena memiliki nilai Cronbach alpha $>0,60$.

\section{Hasil Uji Asumsi Klasik}

Uji normalitas yang gunakan untuk menguji data dalam sebuah model berdistribusi normal atau tidak maka pada hipotesis pertama, kedua dan ketiga dikatakan normal karena mengikuti pola kurva normal.

Hasil perhitungan uji multikolineritas nilai Variance Inflation Factor (VIF) menunjukkan bahwa tidak ada nilai VIF variabel eksogen yang memiliki nilai VIF < 10. Disimpulkan bahwa tidak terjadi multikolinearitas antarvariabel eksogen dalam model diagram jalur pada penelitian ini. 


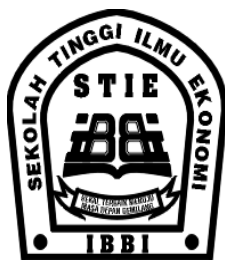

ISSN 1858-3199

JURNAL

MANAJEMEN BISNIS

STIE IBBI

Hasil uji heteroskedastisitas bahwa tidak terdapat pola yang jelas dan teratur baik menyempit, melebar maupun bergelombang. Titik-titik menyebar di atas maupun di bawah angka 0 pada sumbu Y, maka dikatakan tidak terjadi heteroskedastisitas.

\section{Uji Hipotesis 1}

Untuk menguji pengaruh variabel kepribadian, lingkungan dan demografis secara serempak terhadap variabel kepribadian digunakan uji statistik F (Uji F).

Tabel 1. Hasil Pengujian Hipotesis Pertama secara Serempak ANOVA $^{\text {a }}$

\begin{tabular}{|ll|r|r|r|r|l|}
\hline \multicolumn{1}{|c|}{} & \multicolumn{1}{|c|}{$\begin{array}{l}\text { Sum of } \\
\text { Model }\end{array}$} & \multicolumn{1}{c|}{ Squares } & \multicolumn{1}{c|}{$\mathrm{df}$} & Mean Square & \multicolumn{1}{c|}{$\mathrm{F}$} & Sig. \\
\hline 1 & Regression & 13.232 & 3 & 4.411 & 2.226 & $.086^{\circ}$ \\
& Residual & 388.448 & 196 & 1.982 & & \\
& Total & 401.680 & 199 & & & \\
\hline
\end{tabular}

a. Dependent Variable: Minat Kewirausahaan

b. Predictors: (Constant), Demografi, Lingkungan, Keperibadian

menunjukkan bahwa nilai Fhitung $=2,226$ sedangkan FTabel pada tingkat interval kepercayaan (confidence interval) 95\% atau alpha $(\alpha)=0,05$ adalah sebesar 2,70 maka Fhitung > FTabel, keputusannya Ho ditolak dan Ha diterima sehingga dengn demikian disimpulkan bahwa variabel kepribadian, lingkungan, demografis secara serempak berpengaruh sangat signifikan terhadap variabel minat kewirausahaan.

Tabel 2. Nilai Koefisien Determinasi $\left(\mathbf{R}^{2}\right)$

Model Summary ${ }^{\text {b }}$

\begin{tabular}{|c|c|c|c|c|c|c|c|c|c|c|}
\hline \multirow[b]{2}{*}{ Model } & \multirow[b]{2}{*}{$\mathrm{R}$} & \multirow[b]{2}{*}{ R Square } & \multirow[b]{2}{*}{$\begin{array}{l}\text { Adjusted R } \\
\text { Square }\end{array}$} & \multirow[b]{2}{*}{$\begin{array}{l}\text { Std. Error of } \\
\text { the Estimate }\end{array}$} & \multicolumn{5}{|c|}{ Change Statistics } & \multirow[b]{2}{*}{$\begin{array}{l}\text { Durbin- } \\
\text { Watson }\end{array}$} \\
\hline & & & & & $\begin{array}{c}\text { R Square } \\
\text { Change }\end{array}$ & F Change & $\mathrm{df} 1$ & $\mathrm{df} 2$ & Sig. F Change & \\
\hline 1 & $.181^{\mathrm{a}}$ & .033 & .018 & 1.40779 & .033 & 2.226 & 3 & 196 & .086 & 1.294 \\
\hline
\end{tabular}

Hasil uji Determinasi menunjukkan bahwa angka Adjusted $R$ square diperoleh nilai 0,18 hal ini menunjukkan bahwa variable kepribadian, lingkungan, demografis secara serempak mampu menjelaskan variable minat kewirausahaan sebesar $18 \%$. Sisanya $82 \%$ dipengaruhi oleh faktor lain yang tidak diteliti.

Faktor lain yang belum diteliti dalam penelitian ini cukup banyak antara lain dalam penelitian yang dilakukan oleh Basu (2009) menemukan bahwa faktor etnisitas dan pekerjaan orang tua dapat mempengaruhi minat kewirausahaan seseorang. Selain itu penelitian yang dilakukan Mazzarol et al. dalam Saud et .al. (2009) menemukan bahwa faktor demografi seperti etnisitas, status perkawinan, tingkat pendidikan, ukuran keluarga, status dan pengalaman kerja, usia, jender, status sosio-ekonomi, agama juga dapat mempengaruhi minat mendirikan usaha seseorang. 


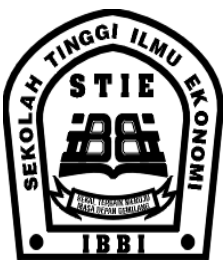

ISSN 1858-3199

JURNAL

MANAJEMEN BISNIS

STIE IBBI

Tabel 3. Hasil Pengujian Hipotesis Pertama secara Parsial

\begin{tabular}{|c|c|c|c|c|c|c|c|c|}
\hline \multicolumn{9}{|c|}{ Coefficients $^{\mathrm{a}}$} \\
\hline \multirow{2}{*}{\multicolumn{2}{|c|}{ Model }} & \multicolumn{2}{|c|}{ Unstandardized Coefficients } & \multirow{2}{*}{$\begin{array}{c}\begin{array}{c}\text { Standardized } \\
\text { Coefficients }\end{array} \\
\text { Beta }\end{array}$} & \multirow[b]{2}{*}{$\mathrm{t}$} & \multirow[b]{2}{*}{ Sig. } & \multicolumn{2}{|c|}{ Collinearity Statistics } \\
\hline & & $B$ & Std. Error & & & & Tolerance & VIF \\
\hline \multirow[t]{4}{*}{1} & (Constant) & 19.775 & 1.944 & & 10.172 & .000 & & \\
\hline & Keperibadian & -.046 & .077 & -.043 & -.596 & .552 & .953 & 1.050 \\
\hline & Lingkungan & -.160 & .069 & -.167 & -2.322 & .021 & .954 & 1.048 \\
\hline & Demografi & .074 & .052 & .103 & 1.414 & .159 & .922 & 1.085 \\
\hline
\end{tabular}

a. Dependent Variable: Minat Kewirausahaan

Nilai $t_{\text {hitung }}$ dari setiap variabel dibandingkan dengan nilai $t_{\text {tabel }}$ dengan tingkat kepercayaan 95\%, maka diperoleh $\mathrm{t}_{\text {tabel }}=1,98$. Untuk variabel kepribadian, nilai $\mathrm{t}_{\text {hitung }}-.596$ berarti $\mathrm{t}_{\text {hitung }}<\mathrm{t}_{\text {tabel }}$. Kesimpulan yang diperoleh dalam melakukan uji t dalam penelitian ini adalah variabel kepribadian secara parsial berpengaruh signifikan terhadap variabel minat kewirausahaan.

Sedangkan pada variabel lingkungan, nilai $t_{\text {hitung }}-2.322$ berarti nilai $t_{\text {hitung }}<t_{\text {tabel }}$. Hal ini menunjukkan bahwa variabel lingkungan secara parsial berpengaruh signifikan terhadap variabel minat kewirausahaan.

Dan pada variabel demografis diperoleh bahwa, nilai $t_{\text {hitung }} 1,414$ yang menunjukkan nilai $\mathrm{t}_{\text {hitung }}<\mathrm{t}_{\text {tabel }}$. Hal ini menunjukkan bahwa variabel demografis secara parsial tidak berpengaruh terhadap variabel minat kewirausahaan.

\section{Uji Hipotesis 2}

Dalam menguji pengaruh variabel efikasi diri dan kebutuhan akan prestasi diri secara serempak terhadap variabel kepribadian, maka dilakukan uji statistik F (Uji F).

Tabel 4. Hasil Pengujian Hipotesis Kedua secara Serempak ANOVA $^{\text {a }}$

\begin{tabular}{|ll|r|r|r|r|r|}
\hline \multicolumn{2}{|c|}{} & $\begin{array}{l}\text { Sum of } \\
\text { Sodel }\end{array}$ & \multicolumn{1}{c|}{ df } & Mean Square & F & Sig. \\
\hline 1 & Regression & 1.081 & 2 & .540 & .304 & $.738^{\circ}$ \\
& Residual & 350.314 & 197 & 1.778 & & \\
& Total & 351.395 & 199 & & & \\
\hline
\end{tabular}

a. Dependent Variable: Keperibadian

b. Predictors: (Constant), Efikasi Diri, Kebutuhan akan prestasi

Hasil uji serempak menunjukkan bahwa nilai $\mathrm{F}_{\text {hitung }} 0,304$ sedangkan $\mathrm{F}_{\text {Tabel }}$ pada tingkat interval kepercayaan (confidence interval) 95\% atau alpha $(\alpha)=0,05$ adalah sebesar 3,09 maka $\mathrm{F}_{\text {hitung }}>\mathrm{F}_{\text {Tabel }}$, Dengan demikian maka keputusannya adalah Ho ditolak dan Ha diterima, hal ini menunjukkan bahwa variabel kebutuhan akan prestasi, efikasi diri secara serempak berpengaruh sangat signifikan terhadap variabel kepribadian. 


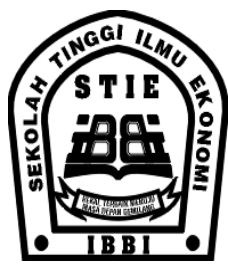

ISSN 1858-3199

JURNAL

MANAJEMEN BISNIS

STIE IBBI

Tabel 5. Nilai Koefisien Determinasi (R2)

\begin{tabular}{|c|c|c|c|c|c|c|c|c|c|c|}
\hline \multirow[b]{3}{*}{ Model } & \multirow[b]{3}{*}{$\mathrm{R}$} & \multirow[b]{3}{*}{ R Square } & \multirow[b]{3}{*}{$\begin{array}{c}\text { Adjusted R } \\
\text { Square }\end{array}$} & \multirow[b]{3}{*}{$\begin{array}{l}\text { Std. Error of } \\
\text { the Estimate }\end{array}$} & \multicolumn{5}{|c|}{ Model Summary } & \multirow[b]{3}{*}{$\begin{array}{l}\text { Durbin- } \\
\text { Watson }\end{array}$} \\
\hline & & & & & \multicolumn{5}{|c|}{ Change Statistics } & \\
\hline & & & & & $\begin{array}{c}\text { R Square } \\
\text { Change }\end{array}$ & F Change & df1 & df2 & Sig. F Change & \\
\hline 1 & $.055^{\mathrm{a}}$ & .003 & -.007 & 1.33351 & .003 & .304 & 2 & 197 & .738 & 1.620 \\
\hline
\end{tabular}

Kemampuan variabel kebutuhan akan prestasi $\left(\mathrm{X}_{2}\right)$ dan efikasi diri $\left(\mathrm{X}_{3}\right)$ dalam menjelaskan pengaruhnya terhadap variabel kepribadian ditunjukkan pada Tabel 5. Dari angka R square (R2) diperoleh nilai -,007 yang artinya variabel efikasi diri dan kebutuhan akan prestasi secara serempak mampu menjelaskan variabel kepribadian sebesar $-7 \%$.

Harris dalam Suryana (2006) menyatakan bahwa wirausaha yang sukses pada umumnya adalah mereka yang memiliki kompetensi yaitu memiliki ilmu pengetahuan, ketrampilan dan kualitas individu yang meliputi sikap, motivasi, nilai-nilai pribadi serta tingkah laku yang diperlukan untuk melaksanakan pekerjaan. Pengetahuan saja tidak cukup bagi seorang wirausaha tetapi harus dibarengi dengan berbagai ketrampilan seperti ketrampilan manajerial, konseptual, memahami komunikasi, merumuskan masalah, mengatur dan menggunakan waktu, ketrampilan teknik, dan lain-lain.

Tabel 6. Hasil Pengujian Hipotesis Kedua Secara Parsial Coefficients $^{\mathrm{a}}$

\begin{tabular}{|c|c|c|c|c|c|c|c|c|}
\hline \multirow{2}{*}{\multicolumn{2}{|c|}{ Model }} & \multicolumn{2}{|c|}{ Unstandardized Coefficients } & \multirow{2}{*}{$\begin{array}{c}\begin{array}{c}\text { Standardized } \\
\text { Coefficients }\end{array} \\
\text { Beta }\end{array}$} & \multirow[b]{2}{*}{$\mathrm{t}$} & \multirow[b]{2}{*}{ Sig. } & \multicolumn{2}{|c|}{ Collinearity Statistics } \\
\hline & & $B$ & Std. Error & & & & Tolerance & VIF \\
\hline \multirow[t]{3}{*}{1} & (Constant) & 16.706 & 1.446 & & 11.555 & .000 & & \\
\hline & $\begin{array}{l}\text { Kebutuhan akan } \\
\text { prestasi }\end{array}$ & .022 & .073 & .023 & .303 & .762 & .856 & 1.168 \\
\hline & Efikasi Diri & .039 & .072 & .042 & .549 & .583 & .856 & 1.168 \\
\hline
\end{tabular}

a. Dependent Variable: Keperibadian

Nilai $t_{\text {hitung }}$ dari setiap variabel dibandingkan dengan nilai $t_{\text {tabel }}$ dengan tingkat kepercayaan $95 \%$ atau $\alpha=0,05 / 2=0,025$, maka diperoleh $\mathrm{t}_{\text {tabel }}=1,98$. Dari tabel terlihat bahwa untuk variabel efikasi diri, nilai $t_{\text {hitung }}=, 549$ berarti $t_{\text {hitung }}<t_{\text {tabel }}$. Kesimpulannya bahwa variabel efikasi diri secara parsial berpengaruh signifikan terhadap variabel kepribadian. Untuk variabel kebutuhan akan prestasi, nilai $t_{\text {hitung }}=, 303$ berarti nilai $t_{\text {hitung }}<t_{\text {tabel. }}$. Kesimpulannya bahwa variabel kebutuhan akan prestasi secara parsial berpengaruh signifikan terhadap variabel kepribadian.

Dari hasil penelitian ini dapat disimpulkan bahwa variabel eksogen kebutuhan akan prestasi dan efikasi diri terbukti mempunyai pengaruh secara serempak dan parsial terhadap minat kewirausahaan mahasiswa Strata-1 di Perguruan Tinggi Negeri Di Medan. Hal ini didukung oleh penelitian Indarti et al. (2008) dan Setiyorini (2009) yang menemukan bahwa efikasi diri mempengaruhi minat kewirausahaan mahasiswa. Penelitian Indarti et al. sebaliknya menemukan bahwa variabel kebutuhan akan prestasi tidak mempunyai pengaruh yang positif terhadap minat kewirausahaan mahasiswa Indonesia dan Norwegia. 


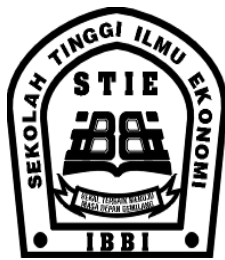

ISSN 1858-3199

JURNAL

MANAJEMEN BISNIS

STIE IBBI

\section{Uji Hipotesis 3}

Pengujian hipotesis ketiga terhadap pengaruh variabel ketersediaan informasi kewirausahaan, kepemilikan jaringan sosial dan akses kepada modal secara serempak terhadap variabel lingkungan menggunakan uji statistik F (Uji F).

Tabel 7. Hasil Pengujian Hipotesis Ketiga Secara Serempak

ANOVA $^{\text {a }}$

\begin{tabular}{|ll|r|r|r|r|r|}
\hline Model & & \multicolumn{1}{|c|}{$\begin{array}{c}\text { Sum of } \\
\text { Squares }\end{array}$} & \multicolumn{1}{c|}{$\mathrm{df}$} & Mean Square & \multicolumn{1}{c|}{$\mathrm{F}$} & \multicolumn{1}{c|}{ Sig. } \\
\hline 1 & Regression & 341.594 & 3 & 113.865 & 226.605 & $.000^{5}$ \\
& Residual & 98.486 & 196 & .502 & & \\
Total & 440.080 & 199 & & & \\
\hline
\end{tabular}

a. Dependent Variable: Lingkungan

b. Predictors: (Constant), Akses Kepada Modal, Ketersediaan Informasi, Kepemilikan Jaringan Sosial

Hasil yang diperoleh dalam pengujian hipotesis secara serempak dapat dilihat pada Tabel 7 di atas terlihat bahwa nilai $\mathrm{F}_{\text {hitung }}=226,605$ sedangkan $\mathrm{F}_{\text {tabel }}$ pada tingkat interval kepercayaan (confidence interval) 95\% atau alpha $(\alpha)=0,05$ adalah sebesar 2,70 maka $\mathrm{F}_{\text {hitung }}>\mathrm{F}_{\text {Tabel }}$, keputusannya Ho ditolak dan Ha diterima.

Tabel 8. Nilai Koefisien Determinasi (R2)

Model Summary

\begin{tabular}{|c|c|c|c|c|c|c|c|c|c|c|}
\hline \multirow[b]{2}{*}{ Model } & \multirow[b]{2}{*}{$\mathrm{R}$} & \multirow[b]{2}{*}{ R Square } & \multirow[b]{2}{*}{$\begin{array}{c}\text { Adjusted R } \\
\text { Square }\end{array}$} & \multirow[b]{2}{*}{$\begin{array}{l}\text { Std. Error of } \\
\text { the Estimate }\end{array}$} & \multicolumn{5}{|c|}{ Change Statistics } & \multirow[b]{2}{*}{$\begin{array}{l}\text { Durbin- } \\
\text { Watson }\end{array}$} \\
\hline & & & & & $\begin{array}{c}\text { R Square } \\
\text { Change }\end{array}$ & F Change & $\mathrm{df} 1$ & $\mathrm{df} 2$ & Sig. F Change & \\
\hline 1 & $.881^{\mathrm{a}}$ & .776 & .773 & .70886 & .776 & 226.605 & 3 & 196 & .000 & 1.223 \\
\hline
\end{tabular}

a. Predictors: (Constant), Akses Kepada Modal, Ketersediaan Informasi, Kepemilikan Jaringan Sosial

b. Dependent Variable: Lingkungan

Berdasarkan hasil uji determinasi diperoleh hasil Adjusted $R$ square (R2) 0,773 yang artinya adalah variable ketersediaan informasi kewirausahaan, kepemilikan jaringan sosial dan akses kepada modal secara serempak mampu menjelaskan variabel lingkungan sebesar $77,3 \%$. Sisanya $22,7 \%$ dipengaruhi oleh faktor lain yang tidak diteliti.

Menurut Zimmerer (2004) banyak faktor lingkungan yang berpengaruh terhadap minat kewirausahaan antara lain budaya masyarakat bahwa wirausaha adalah perubahan ekonomi, kemajuan teknologi, kemajuan internet dan globalisasi. Dewanti (2008: 11) menyatakan faktor lingkungan berpengaruh terhadap minat kewirausahaan, faktor lingkungan yang berpengaruh adalah situasi yang menguntungkan, model peranan, aktivitas, pesaing dengan industri yang sama, inkubator sebagai sumber ide, sumber daya alam dan manusia, teknologi dan kebijakan pemerintah. Mazzarol et al. dalam Saud et al. (2009) menemukan bahwa faktor lingkungan (faktor sosial, ekonomi, politik dan perkembangan infrastruktur) mempengaruhi minat kewirausahaan. 


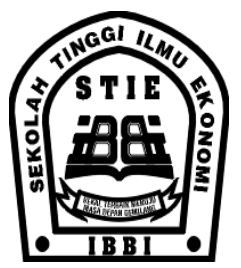

ISSN 1858-3199

JURNAL

MANAJEMEN BISNIS

STIE IBBI

Tabel 9. Hasil Pengujian Hipotesis Ketiga Secara Parsial

Coefficients $^{\mathrm{a}}$

\begin{tabular}{|c|c|c|c|c|c|c|c|c|}
\hline \multirow{2}{*}{\multicolumn{2}{|c|}{ Model }} & \multicolumn{2}{|c|}{ Unstandardized Coefficients } & \multirow{2}{*}{$\begin{array}{c}\begin{array}{c}\text { Standardized } \\
\text { Coefficients }\end{array} \\
\text { Beta }\end{array}$} & \multirow[b]{2}{*}{$t$} & \multirow[b]{2}{*}{ Sig. } & \multicolumn{2}{|c|}{ Collinearity Statistics } \\
\hline & & B & Std. Error & & & & Tolerance & VIF \\
\hline \multirow[t]{2}{*}{1} & (Constant) & .603 & .738 & & .817 & .415 & & \\
\hline & $\begin{array}{l}\text { Kepemilikan Jaringan } \\
\text { Sosial }\end{array}$ & -.038 & .065 & -.027 & -.586 & .559 & .529 & 1.890 \\
\hline
\end{tabular}

a. Dependent Variable: Lingkungan

Nilai $t_{\text {hitung }}$ dari setiap variabel dibandingkan dengan nilai $t_{\text {tabel }}$ dengan tingkat kepercayaan $95 \%$ atau $\alpha=0,05 / 2=0,025$, maka diperoleh $\mathrm{t}_{\text {tabel }}=1,98$. Dari tabel di atas terlihat bahwa untuk variabel ketersediaan informasi kewirausahaan, nilai $t_{\text {hitung }}=2,555$ berarti $t_{\text {hitung }}>t_{\text {tabel }}$. Kesimpulannya bahwa variabel ketersediaan informasi kewirausahaan secara parsial berpengaruh signifikan terhadap variabel lingkungan. Untuk variabel kepemilikan jaringan sosial, nilai $t_{\text {hitung }}$ 19,197 berarti nilai $t_{\text {hitung }}>t_{\text {tabel }}$. Kesimpulannya bahwa variabel kepemilikan jaringan sosial secara parsial berpengaruh signifikan terhadap variabel kepribadian. Untuk variabel akses kepada modal, nilai $t_{\text {hitung }}=4,613$ berarti nilai $t_{\text {hitung }}>t_{\text {tabel }}$, kesimpulannya bahwa variabel akses kepada modal secara parsial berpengaruh signifikan terhadap variabel lingkungan.

\section{Korelasi Antar Variabel Penelitian}

a. Dari hasil pengolahan data menunjukkan bahwa korelasi antara variabel kebutuhan berprestasi (X2) dengan efikasi diri (X3) sebesar 0,380. Nilai korelasi yang positif menunjukkan bahwa semakin besar kebutuhan berprestasi maka akan semakin besar pula efikasi diri.

b. korelasi antara variabel kebutuhan informasi (X4) dengan Jaringan social (X5) sebesar 0,551. Nilai korelasi yang positif menunjukkan bahwa semakin besar kebutuhan berprestasi maka akan semakin besar pula efikasi diri.

c. Korelasi antara variabel kebutuhan informasi (X4) dengan Akses (X6) sebesar 0,451. Nilai korelasi yang positif menunjukkan bahwa semakin besar kebutuhan berprestasi maka akan semakin besar pula efikasi diri.

d. Korelasi antara variabel Jaringan social (X5) dengan Akses (X6) sebesar 0,613. Nilai korelasi yang positif menunjukkan bahwa semakin besar kebutuhan berprestasi maka akan semakin besar pula efikasi diri.

e. Korelasi antara variabel Demografi (X1) dengan Kepribadian (Y2) sebesar 0,209. Nilai korelasi yang positif menunjukkan bahwa semakin besar kebutuhan berprestasi maka akan semakin besar pula efikasi diri.

f. Korelasi antara variabel Demografi (X1) dengan Lingkungan (Y3) sebesar 0,206. Nilai korelasi yang positif menunjukkan bahwa semakin besar kebutuhan berprestasi maka akan semakin besar pula efikasi diri.

g. Korelasi antara variabel Kepribadian (Y2) dengan Lingkungan (Y3) sebesar 0,163. Nilai korelasi yang positif menunjukkan bahwa semakin besar kebutuhan berprestasi maka akan semakin besar pula efikasi diri.

\section{Model diagram jalur penelitian}

Model diagram jalur penelitian untuk hipotesis di atas sesuai ditunjukkan oleh Gambar 1. Dari model diagram jalur tersebut dapat dibuat tiga persamaan substruktur berikut ini: 


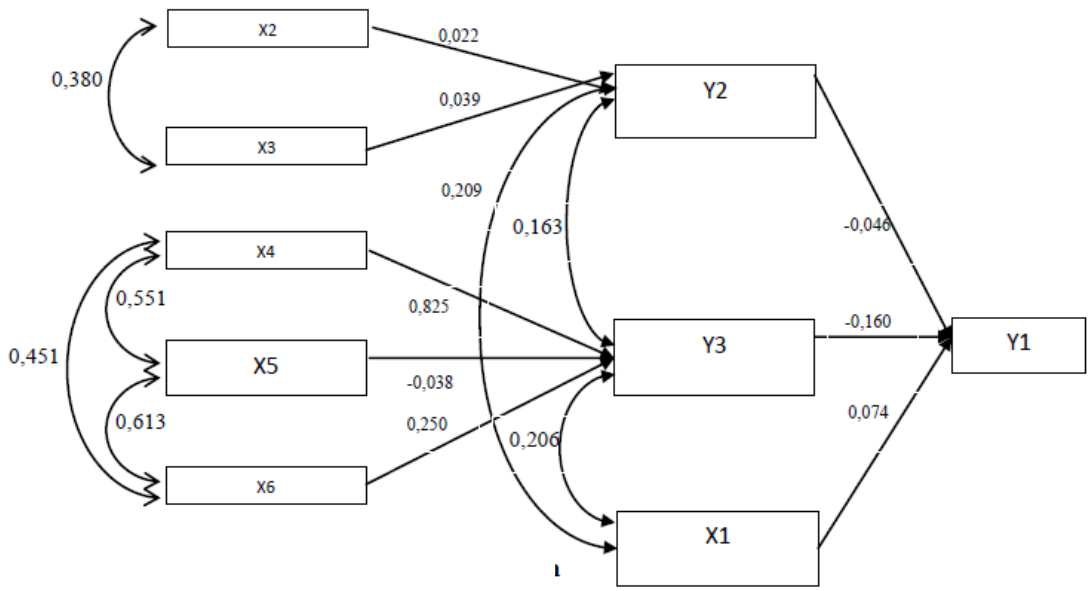

Gambar 1. Model Diagram Jalur Penelitian

\section{Kesimpulan dan Saran}

\section{Kesimpulan}

1. Variabel kepribadian, lingkungan, demografis secara serempak berpengaruh sangat signifikan terhadap variabel minat kewirausahaan. variabel kepribadian, lingkungan, demografis secara serempak mampu menjelaskan variable minat kewirausahaan sebesar $18 \%$. Sisanya $82 \%$ dipengaruhi oleh faktor lain yang tidak diteliti.

2. Variabel kebutuhan akan prestasi, efikasi diri secara serempak berpengaruh sangat signifikan terhadap variabel kepribadian. variabel efikasi diri dan kebutuhan akan prestasi secara serempak mampu menjelaskan variable kepribadian sebesar $-7 \%$. Sisanya dipengaruhi oleh faktor lain yang tidak diteliti.

3. Variabel ketersediaan informasi kewirausahaan, kepemilikan jaringan social dan akses kepada modal secara serempak berpengaruh sangat signifikan terhadap variabel lingkungan. variable ketersediaan informasi kewirausahaan, kepemilikan jaringan sosial dan akses kepada modal secara serempak mampu menjelaskan variabel lingkungan sebesar 77,3\%. Sisanya 22,7\% dipengaruhi oleh faktor lain yang tidak diteliti.

4. Korelasi antara variabel kebutuhan berprestasi dengan efikasi diri sebesar 0,380. korelasi antara variabel kebutuhan informasi dengan Jaringan social sebesar 0,551. korelasi antara variabel kebutuhan informasi dengan Akses sebesar 0,451. korelasi antara variabel Jaringan social dengan Akses sebesar 0,613. korelasi antara variabel Demografi dengan Kepribadian sebesar 0,209. korelasi antara variabel Demografi dengan Lingkungan sebesar 0,206. korelasi antara variabel Kepribadian dengan Lingkungan sebesar 0,163. Nilai korelasi yang positif menunjukkan bahwa semakin besar kebutuhan berprestasi maka akan semakin besar pula efikasi diri.

\section{Saran}

1. Variabel kepribadian dan lingkungan merupakan variabel yang berperan penting dalam menumbuhkan minat kewirausahaan mahasiswa Strata-1 pada perguruan tinggi negeri di 
Medan, untuk itu pihak universitas diharapkan dapat menciptakan program yang dapat menumbuhkan kepribadian dan lingkungan kampus yang positif untuk mendukung tumbuhnya minat kewirausahaan mahasiswa.

2. Variabel kepribadian merupakan faktor yang paling dominan yang mempengaruhi minat kewirausahaan mahasiswa Strata-1 pada perguruan tinggi negeri di Medan oleh karena itu sejak awal mahasiswa yang kuliah di universitas negeri di Medan, perlu dibentuk kepribadian yang mendukung tumbuhnya minat kewirausahaan mahasiswa tersebut melalui pelatihan baik di dalam kelas maupun di luar kelas dengan metode yang lebih beragam agar mahasiswa tidak jenuh sehingga dapat mendukung pembentukan kepribadian yang positif.

3. Lingkungan merupakan variabel yang mempengaruhi minat kewirausahaan mahasiswa, oleh karena itu perguruan tinggi negeri di Medan perlu memberikan berbagai macam jenis informasi tentang kewirausahaan dengan cara memberikan mata kuliah kewirausahaan, seminar kewirausahaan dan seminar bisnis yang sebaiknya diikuti oleh seluruh mahasiswa dari semua fakultas tanpa kecuali kepada semua mahasiswa, dosen dan pegawai yang ada di lingkungan kampus.

\section{Daftar Pustaka}

Hisrich, Robert D., Michael P. Peters dan Dean A. Shepherd, 2008. Kewirausahaan, Edisi 7, Penerbit Salemba Empat, Jakarta.

Kasmir, 2007. Kewirausahaan, Edisi 1, Penerbit PT RajaGrafindo Persada, Jakarta.

Lupiyoadi, Rambat, 2007. Entrepreneurship From Mindset To Strategy, Cetakan Ketiga, Lembaga Penerbit Fakultas Ekonomi Universitas Indonesia, Jakarta.

Manurung, Adler Haymans, 2008. Modal untuk Bisnis UKM, Cetakan Kedua, Penerbit PT Kompas Media Nusantara, Jakarta.

Mudjiarto dan Aliaras Wahid, 2006. Membangun Karakter dan Kepribadian Kewirausahaan, Edisi Pertama, Cetakan Pertama, Penerbit Graha Ilmu dan UIEU University Press, Yogyakarta dan Jakarta.

Slameto. 2013. Belajar dan Faktor-faktor yang Mempengaruhinya. Jakarta: Rineka Cipta.

Sunyoto, Danang, 2009. Analisis Regresi dan Uji Hipotesis, Cetakan Pertama, Penerbit Medpress, Yogyakarta.

Suryana, 2006. Kewirausahaan Pedoman Praktis: Kiat dan Proses Menuju Sukses, Edisi Ketiga, Penerbit Salemba, Jakarta.

Tunggal, Amin Wijaya, 2008. Pengantar Kewirausahaan, Edisi Revisi, Penerbit Harvarindo, Jakarta.

Zimmerer, Thomas W. dan Norman Scarborough, 2004. Pengantar Kewirausahaan dan Manajemen Bisnis Kecil, Gramedia, Jakarta.

Yasin dkk, 2007. Dasar-dasar Demografi, Lembaga Penerbit Fakultas Ekonomi UI, Jakarta.

Jurnal:

Basu, Anurudha et.al, (2009). Assessing Entrepreneurial Intentions Amongst Students: A Comparative Study, San Jose State University (tidak dipublikasikan). http://nciia.org.

Gadar, Kamisan dan Nek Kamal Yeop Yunus, (2009). The Influence of Personality and SocioEconomic Factors on Female Entrepreneurship Motivations in Malaysia, International Review of Business Research Papers, January, 5 (1), 149 - 162 
Indarti, Nurul dan Rokhima Rostianti, (2008). Intensi Kewirausahaan Mahasiswa: Studi Perbandingan Antara Indonesia, Jepang dan Norwegia, Ekonomika dan Bisnis Indonesia, Oktober, 23 (4).

Muhyi, Herwan Abdul, (2007). Menumbuhkan Jiwa dan Kompetensi Kewirausahaan, Universitas Padjadjaran. Bandung (tidak dipublikasikan).

Napitupulu, Ester Lince, (2009). Lulusan Perguruan Tinggi Hanya Berorientasi Jadi Pencari Kerja, Kompas.Com, Jakarta.

Saud, Mohammad Basir dan Mohd Noor Sharrif, (2009). An Attitude Approach To the Prediction of Entrepreneurship on Students at Institution of Higher Learning in Malaysia, International Journal of Business and Management. July, 4 (4), 129 . 135.

Siswoyo, H. Bambang Banu, (2009). Pengembangan Jiwa Kewirausahaan di Kalangan Dosen dan Mahasiswa, Jurnal Ekonomi Bisnis, Tahun 14 No 2, Juli.

Yohnson, (2003). Peranan Universitas dalam Memotivasi Sarjana Menjadi Young Entrepreneurs, Jurnal Manajemen \& Kewirausahaan, 5 (2), September, 97 . 111.

Yuwono, Susatyo dan Partini, (2008). Pengaruh Pelatihan Kewirausahaan Terhadap Tumbuhnya Minat Berwirausaha, Jurnal Penelitian Humaniora, Vol 9 No 2, Agustus, 119 $-127$

http://www.analisadaily.com/news/read/2013/01/09 07:35 WIB 


\title{
ANALISIS TINGKAT KEPUASAN MASYARAKAT TERHADAP PELAYANAN PT PLN (PERSERO) CABANG MEDAN BARU KOTAMADYA MEDAN SUMATERA UTARA
}

\author{
Lili Suryati ${ }^{*}$ \\ Andriasan Sudarso *) \\ ${ }^{*}$ Dosen Program Studi S-1 Manajemen STIE IBBI
}

\begin{abstract}
Abstrak
Penelitian ini dilakukan untuk mengetahui harapan apa yang diinginkan oleh masyarakat, sejauh mana pelayanan publik telah diberikan dan bagaimana tingkat kepuasan masyarakat Kecamatan Medan Baru mengenai kualitas pelayanan publik PT PLN (Persero) Cabang Medan Baru. Metode yang digunakan adalah metode survei. Instrumen penelitian yang sesuai dengan KEPMENPAN No. KEP/25/M.PAN/2/2004 dengan jumlah sampel sebanyak 200 orang yang merupakan masyarakat Kecamatan Medan Baru. Data hasil survei ditabulasi dan diolah dengan menggunakan analisis Indeks Kepuasan Masyarakat (IKM) dan Importance Perfomance Analysis (IPA). Hasil analisis IKM menunjukan bahwa hanya unsur kenyamanan lingkungan yang memenuhi harapan masyarakat, sedangkan 13 unsur lainnya masih belum dapat memenuhi harapan masyarakat. Secara keseluruhan nilai IKM yang diperoleh sebesar 2,36 yang menunjukan bahwa kinerja mutu pelayanan PT PLN Persero Cabang Medan Baru masih tergolong kurang baik. Hasil analisis IPA menunjukan bahwa unsur-unsur yang memiliki nilai rata-rata kepentingan lebih besar dari 3,156adalah unsur yang menurut masyarakat sangat penting dalam rangka memenuhi kepuasannya.Oleh karena itu, unsur-unsur tersebut harus mendapat perhatian yang serius dari pihak manajemen PT PLN Persero Cabang Medan Baru. Unsur-unsur yang sesuai dengan harapan masyarakat dan perlu dipertahankan kinerjanya adalah unsur kemampuan petugas pelayanan serta unsur keramahan dan kesopanan petugas pelayanan. Sebaliknya, unsur-unsur yang menurut masyarakat sangat penting tetapi kinerjanya tidak memuaskan seharusnya mendapatkan perhatian serius dan menjadi prioritas utama untuk segera diperbaiki kinerjanya adalah unsur kejelasan petugas pelayanan, unsur kedisplinan petugas pelayanan, unsur tanggung jawab petugas pelayanan, unsur kecepatan petugas pelayanan dan unsur keadilan mendapatkan pelayanan.
\end{abstract}

Kata Kunci: Indeks Kepuasan Masyarakat, Importance Performance Analysis, Kinerja, Kepentingan 


\title{
ANALISIS TINGKAT KEPUASAN MASYARAKAT TERHADAP PELAYANAN PT PLN (PERSERO) CABANG MEDAN BARU KOTAMADYA MEDAN SUMATERA UTARA
}

\author{
Lili Suryati *) \\ Andriasan Sudarso *) \\ ${ }^{*)}$ Dosen Program Studi S-1 Manajemen STIE IBBI
}

\begin{abstract}
This study was conducted to determine what the expectations of the community, the extent to which public services have been given and what the community satisfaction index in Medan Baru district on public service quality of PT PLN (Persero) Medan Baru Branch. Survey method was used for this purpose. Research instruments is according to KEPMENPAN No. KEP/25/M.PAN/2/2004 with a total sample of 200 people who are living in Medan BaruDistrict. Survey data were tabulated and analyzed by using analysis of Community Satisfaction Index (CSI) and the Importance Perfomance Analysis (IPA). The results of CSI analysis showed that only the environmental comfort element meetsthe community expectations, while the other 13 elements are still not able to meet the expectations of society. Value of CSIwas 2.36, which indicates that the service quality performance of PT PLN Persero Medan Baru Branch is still relatively poor. The results of IPA showed that the elements, which have an average value of importance greater than 3,156, is very important in order to meet community's satisfaction. Therefore, these elements have to receive serious attention from the management of PT PLN Persero Medan Baru Branch. The elements which are in accordance with the community's expectations and need to be sustained performance, are the ability of service personnel element and friendliness and courtesy of service personnel element. Instead, the elements that are very important in according with the community's expectations but its performance is not satisfactory should be given serious attention and become a top priority for immediate improved performance,areclarity of service personnel element, disipline of service personnel element, responsibility of service personnel element, speed of service personnel element and justice to get service element.
\end{abstract}

Keywords: community satisfaction index, Importance Performance Analysis, Kinerja, Kepentingan

\section{PENDAHULUAN}

Sejak diberlakukannya otonomi daerah, maka pemerintah daerah bertanggung jawab terhadap pelayanan yang diberikan kepada masyarakat masing-masing daerah. Dengan berlakunya ketentuan tersebut, masyarakat harus merasakan kemudahan yang diberikan aparatur negara dalam memberikan pelayanan yang lebih baik, lebih cepat dan tepat. Menurut Keputusan Menteri Pendayagunaan Aparatur Negara Nomor: Kep/25/M.PAN/2/2004 Tentang Pedoman Umum Penyusunan Indeks Kepuasan Masyarakat Unit Pelayanan Instansi Pemerintah,pelayanan publik adalah segala kegiatan pelayanan yang dilaksanakan oleh penyelenggara pelayanan publik sebagai upaya pemenuhan kebutuhan penerima pelayanan, maupun dalam rangka pelaksanaan ketentuan peraturan perundang-undangan. Salah satu bentuk instansi pemerintah adalah Badan Usaha Milik Negara (BUMN), dalam penelitian ini PT PLN (Persero). Sesuai dengan salah satu misi PT PLN (Persero), yaitu berorientasi kepada kepuasan pelanggan, maka sangat penting dibutuhkan analisis kepuasan masyarakat terhadap pelayanan yang telah diberikan oleh PT PLN (Persero). Pelayanan 


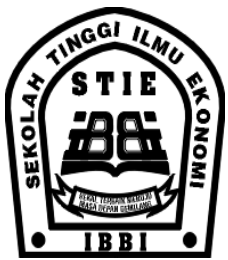

ISSN 1858-3199

JURNAL

MANAJEMEN BISNIS

STIE IBBI

publik oleh aparatur PT PLN (Persero) Wilayah SUMBAGUT dewasa ini masih banyak dijumpai kelemahan sehingga belum dapat memenuhi kualitas yang diharapkan masyarakat. Hal ini ditandai dengan masih banyaknya berbagai keluhan masyarakat yang disampaikan melalui media massa, sehingga dapat menimbulkan citra yang kurang baik terhadap PT PLN (Persero) ini. Masyarakat yang merupakan pelanggan PT PLN (Persero), juga memiliki kebutuhan dan harapan pada kinerja penyelenggara pelayanan publik yang profesional. Sehingga yang sekarang menjadi tugas PT PLN (Persero) adalah bagaimana memberikan pelayanan publik yang mampu memuaskan masyarakat.

Untuk mengetahui harapan apa yang diinginkan oleh masyarakat, sejauh mana pelayanan publik telah diberikan dan bagaimana tingkat kepuasan masyarakat Kecamatan Medan Baru mengenai pelayanan publik yang telah diberikan oleh PT PLN (Persero) Wilayah SUMBAGUT Cabang Medan Baru, maka dibuat suatu penelitian dengan menggunakan analisis statistik, yaitu Analisis Tingkat Kepuasan Masyarakat Terhadap Pelayanan PT PLN (Persero) Wilayah SUMBAGUT Cabang Medan Baru.

\section{TINJAUAN PUSTAKA}

Kata kepuasan (satisfaction) berasal dari bahasa Latin satis yangberarti cukup baik, memadai dan facio artinya melakukan atau membuat.Kepuasan adalah perasaan senang karena sudah terpenuhi hasrathatinya.(Tjiptono, 2005) Dalam Kamus Umum Bahasa Indonesia kata "Kepuasan"diterjemahkan sebagi tingkat kepuasan seseorang telah membandingkankinerja produk (atau hasil) yang ia rasakan dengan harapanya. JadiKepuasan bisa diartikan sebagai upaya pemenuhan sesuatu atau membuatsesuatu memadai.(Tjiptono dan Chandra, 2005) Kepuasan adalah fungsi dari perbedaan antara kinerjayang dirasakan dengan harapan.Jadi tingkat kepuasan merupakan fungsi dari perbedaan antarakinerja yang dirasakan dan harapan, jika kinerja dibawah harapannmasyarakat maka masyarakat akantidak puas, apabila kinerja sesuai dengan harapan, masyarakat akan puas, apabila kinerja melampaui harapan maka nasabah akan sangat puas, senag dan bahagia.

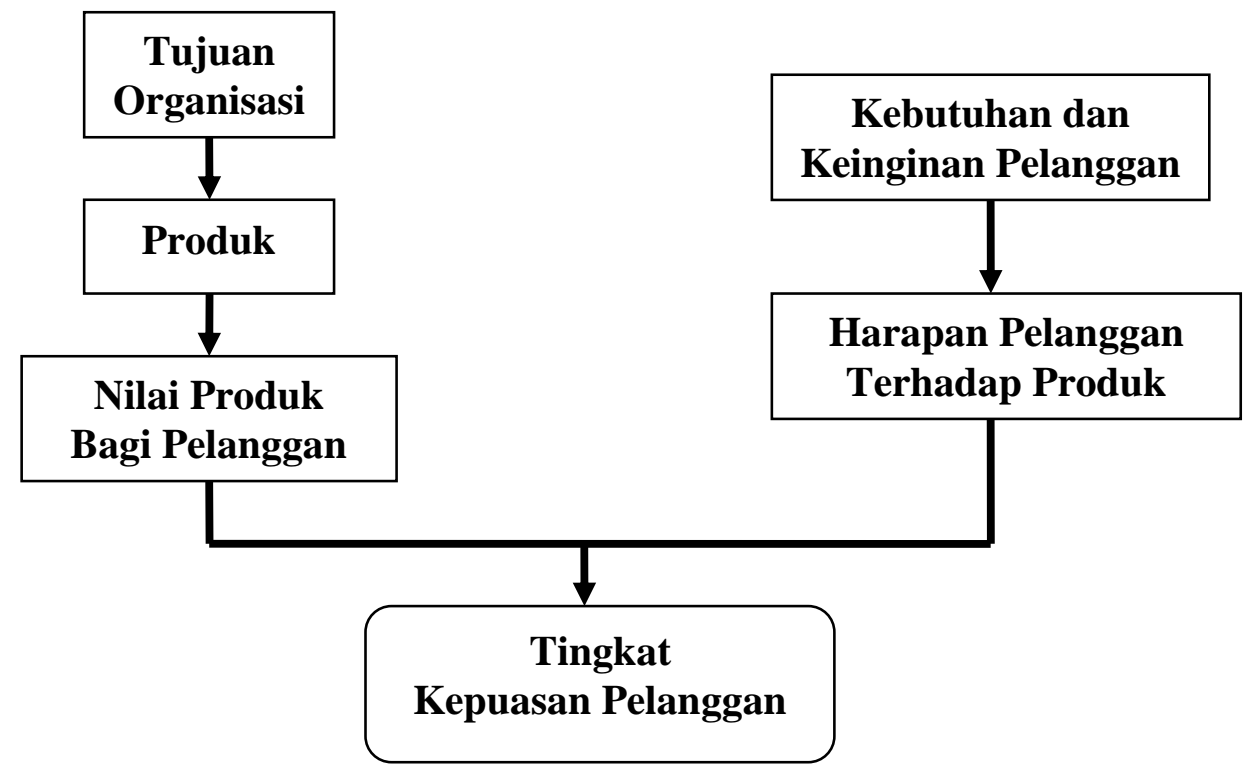

Gambar 1. Diagram Konsep Kepuasan Pelanggan

Sumber : Freddy Rangkuti, 2003 


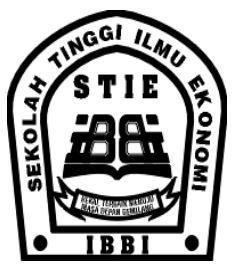

ISSN 1858-3199

JURNAL

MANAJEMEN BISNIS

STIE IBBI

Indeks Kepuasan Masyarakat (IKM) adalah data dan informasi tentang tingkat kepuasan masyarakat yang diperoleh dari hasil pengukuran secara statistic dan pemaparan atas pendapat masyarakat dalam memperoleh pelayanan dari aparatur penyelenggara pelayanan publik dengan membandingkan antara harapan dan kebutuhannya ( Kep.MENPAN No.25/2004).

Berdasarkan prinsip pelayanan sebagaimana telah ditetapkan dalam Kep.MENPAN No. Kep/25/M.Pan/2/2004, yang kemudian dikembangkan menjadi14 unsur yang "relevan, valid" dan "reliabel", sebagai unsur minimal yang harusada untuk dasar pengukuran indeks kepuasan masyarakat adalah sebagai berikut :

1. Prosedur pelayanan, yaitu kemudahan tahapan pelayanan yang diberikan kepada masyarakat dilihat dari sisi kesederhanaan alur pelayanan.

2. Persyaratan Pelayanan, yaitu persyaratan teknis dan administratif yang diperlukan untuk mendapatkan pelayanan sesuai dengan jenis pelayanannya.

3. Kejelasan petugas pelayanan, yaitu keberadaan dan kepastian petugas yang memberikan pelayanan (nama, jabatan serta kewenangan dan tanggung jawab).

4. Kedisiplinan petugas pelayanan, yaitu kesungguhan petugas dalam memberikan pelayanan terutama terhadap konsistensi waktu kerja sesuai ketentuan yang berlaku.

5. Tanggung jawab petugas pelayanan, yaitu kejelasan wewenang dan tanggung jawab petugas dalam penyelenggaraan dan penyelesaian pelayanan.

6. Kemampuan petugas pelayanan, yaitu tingkat keahlian dan keterampilan yang dimiliki petugas dalam memberikan/menyelesaikan pelayanan kepada masyarakat.

7. Kecepatan pelayanan, yaitu target waktu pelayanan dapat diselesaikan dalam waktu yang telah ditentukan oleh unit penyelenggara pelayanan.

8. Keadilan mendapatkan pelayanan, yaitu pelaksanaan pelayanan dengan tidak membedakan golongan/status masyarakat yang dilayani.

9. Kesopanan dan keramahan petugas, yaitu sikap dan perilaku petugas yang memberikan pelayanan kepada masyarakat secara sopan dan ramah serta saling menghargai dan menghormati.

10. Kewajaran biaya pelayanan, yaitu keterjangkauan masyarakat terhadap besarnya biaya yang ditetapkan oleh unit pelayanan.

11. Kepastian biaya pelayanan, yaitu kesesuaian antara biaya yang dibayarkan dengan biaya yang telah ditetapkan.

12. Kepastian jadwal pelayanan, yaitu pelaksanaan waktu pelayanan sesuai dengan ketentuan yang telah ditetapkan.

13. Kenyamanan lingkungan, yaitu kondisi sarana dan prasarana pelayanan yang bersih, rapi, dan teratur sehingga dapat memberikan rasa nyaman kepada penerima pelayanan.

14. Keamanan pelayanan, yaitu terjaminnya tingkat keamanan lingkungan unit penyelenggara pelayanan ataupun sarana yang digunakan, sehingga masyarakat merasa tenang untuk mendapatkan pelayanan terhadap resiko-resiko yang diakibatkan dari pelaksanaan pelayanan.

Tujuan pengukuran kepuasan masyarakat (IKM) menurut Kep.MENPANNo.25/2004 adalah untuk mengetahui perkembangan kinerja unit pelayanan dilingkungan instansi pemerintah yang dilaksanakan oleh instansi yangbersangkutan secara periodik. Dan bagi unit pelayanan di instansi pemerintah,hasil pengukuran dapat digunakan sebagai bahan untuk menetapkan kebijakandalam rangka meningkatkan kualitas pelayanan publik selanjutnya.

Sasaran pengukuran kepuasan masyarakat (IKM) dalam Kep.MENPANNo. 25/2004, yaitu :

1. Tingkat pencapaian kinerja unit pelayanan instansi pemerintah dalam memberikan pelayanan kepada masyarakat 


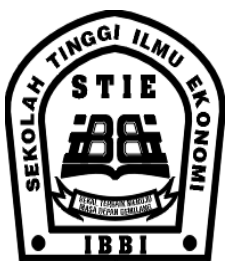

ISSN 1858-3199

JURNAL

MANAJEMEN BISNIS

STIE IBBI

2. Penataan sistem, mekanisme, dan prosedur pelayanan sehingga pelayanan dapat dilaksanakan secara lebih berkualitas, berdaya guna, dan berhasil guna.

3. Tumbuhnya kreativitas, prakarsa, dan peran serta masyarakat dalam upaya peningkatan kualitas pelayanan publik (Rahmayanty , 2010 :96).

Pelayanan adalah upaya untuk membantu menyiapkan, menyediakan, ataumengurus keperluan orang lain. Pelayanan juga merupakan proses pemenuhankebutuhan melalui aktivitas orang lain secara langsung. Pelayanan yaitu usahamelayani kebutuhan orang lain dengan memperoleh imbalan (uang); jasa.Pelayanan dapat diartikan sebagai kemudahan yang diberikan sehubungan denganjual beli barang/jasa.Pelayanan adalah produk-produk yang tidak kasat mata (tidak dapatdiraba) yang melibatkan usaha-usaha manusia dan menggunakan peralatan.Pelayanan adalah suatu aktivitas atau serangkaian aktivitas yang bersifattidak kasat mata (tidak dapat diraba) yang terjadi sebagai akibat adanya interaksiantara konsumen dengan karyawan atau hal-hal lain yang disediakan olehperusahaan pemberi pelayanan yang dimaksudkan untuk memecahkanpermasalahan konsumen/pelanggan dalam (Ratminto \& Atik Septi Winarsih,2006).

Dalam Keputusan Menteri Pendayagunaan Aparatur Negara No.81/1993yang disempurnakan dengan Kep.MENPAN No. 63/2003 mendefinisikan pelayanan umum sebagai segala bentuk pelayanan yang dilaksanakan oleh instansi Pemerintah diPusat, di Daerah, dan di lingkungan Badan Usaha Milik Negara atauBadan Usaha Milik Daerah dalam bentuk barang dan atau jasa, baik dalamrangka upaya pemenuhan kebutuhan masyarakat maupun dalam rangkapelaksanaan ketentuan peraturan perundang-undangan (Rahmayanty,2006).

Berdasarkan uraian diatas, maka peneliti membuat kerangka berfikir yang bersumber dari landasan teori, maka dalam pembuatan kerangka berfikir ini peneliti menggunakan Kep.MENPAN No.25/2004 sebagai unsur minimal yang harus ada untuk dasarpengukuran Indeks Kepuasan Masyarakat.Dari pemaparan yang ada, peneliti menggambarkan kerangka berfikir sebagai berikut :

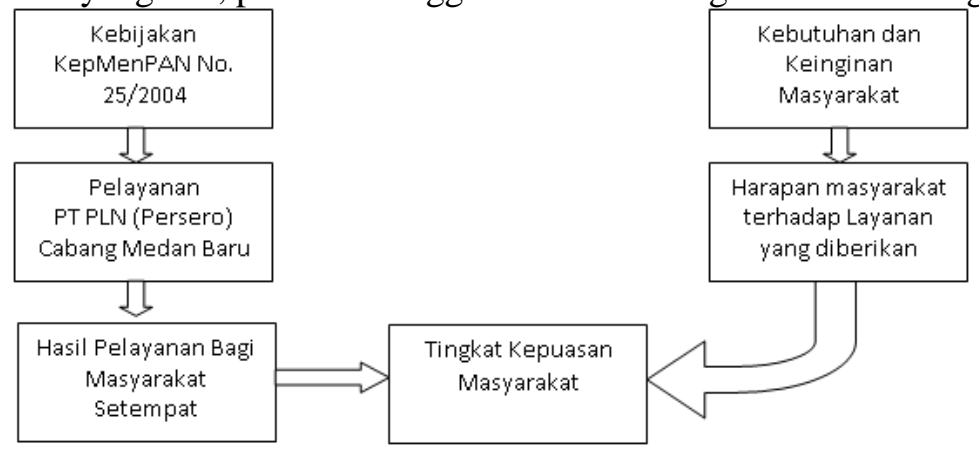

Gambar 2. Kerangka Berfikir

\section{METODOLOGI PENELITIAN}

Pendekatan digunakan dalam penelitian ini adalah metode survey. Penelitian survey pada umumnya dilakukan untuk mengambil suatu generalisasidari pengamatan yang tidak mendalam. Menurut Sugiyono (2007), metode survey adalah penelitian yang dilakukan pada populasi besar maupun kecil, tetapi datayang dipelajari adalah data dari sampel yang diambil dari populasitersebut, sehingga ditemukan kejadian-kejadian relatif, distribusi danhubungan-hubungan antara variabel sosiologis maupun psikologis (Sugiyono, 2007).

Penelitian survey dapat digunakan untuk maksud (1) penjajagan(eksploratif), (2) deskriptif, (3) penjelasan (explanatory atau confirmatory), yakniuntuk menjelaskan hubungan kausal dan 


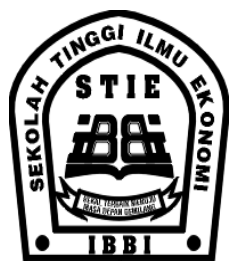

ISSN 1858-3199

JURNAL

MANAJEMEN BISNIS

STIE IBBI

pengujian hipotesa; (4) evaluasi, (5)prediksi atau meramalkan kejadian tertentu di masa yang akan datang, (6)penelitian operasional, dan (7) pengembangan indikator-indikator sosial(Singarimbun \& Sofian Effendi, 2006:4).

1. Instrumen Penelitian

Operasional variabel penelitian menggunakan bahan rujukan KEPMENPAN No. KEP/25/M.PAN/2/2004 tentang Pedoman Umum Penyusunan Indeks Kepuasan Masyarakat Unit Pelayanan Instansi Pemerintah, termasuk unsur-unsur pelayanan yang digunakan sebagai indikator dan metode penentuan indeks kepuasan masyarakat.

2. Populasi dan Sampel

Jumlah responden berdasarkan Kep.MENPAN No.25/2004 tentang Pedoman Penyusunan Indeks Kepuasan Masyarakat Unit Pelayanan Instansi Pemerintah dipilih secara acak yang ditentukan sesuai dengan cakupan wilayah masing-masing unit pelayanan. Menurut Ferdinand (2000), ukuran sample yang sesuai antara 100 - 200. Bila ukuran sample terlalu besar maka metode menjadi sangat sensitive sehingga sulit untuk mendapatkan ukuran - ukuran Goodness of fit yang baik. Dalam penelitian ini menggunakan sampel sebanyak 200 responden yang merupakan masyarakat yang menggunakan layanan public PT PLN (Persero) Cabang Medan Baru.

3. Indeks Kepuasan Masyarakat

Metode pengolahan data menurut KEPMENPAN No.25 tahun 2004, nilai IKMdihitung dengan menggunakan "nilai rata-rata tertimbang" masing-masing unsur pelayanan. Dalam penghitungan indeks kepuasan masyarakat terhadap 14 unsurpelayanan yang dikaji, setiap unsur pelayanan memiliki penimbang yang sama.

4. Importance Performance Analysis (IPA)

Dalam penelitian ini untuk menentukan atribut-atribut yang mempengaruhikepuasan konsumen digunakan metode Importance Performance Analysis (IPA).Metode analisis ini dimaksudkan untuk mengetahui keadaan masing-masingvariabel dari faktor-faktor kepuasan ditinjau dari segi kepentingan dan kenerja.Hasil analisis ini disajikan dalam diagram kartesius dimana penilaian kepentinganmasyarakat ditunjukkan dengan huruf $\mathrm{Y}$, sedang untuk penilaian kinerjapelayanan PT PLN Persero Cabang Medan Baru ditunjukkan dengan huruf X.

\section{HASIL}

Instrumen yang digunakan untuk penelitian ini adalah kuesioner. Adapun dalam kuesioner itu berisikan tentang data pribadi dan deskripsi dari responden tersebut. Data pribadi yang ada tersebut adalah umur, jenis kelamin dan pekerjaan responden. Berdasarkan hasil pengumpulan data dan tabulasi data karakteristik responden dapat dilihat pada tabel 1. berikut.

Tabel 1. Karakteristik Responden

\begin{tabular}{|c|c|c|}
\hline KETERANGAN & JUMLAH & PERSENTASE \\
\hline \multicolumn{3}{|l|}{ UMUR } \\
\hline$<25$ TAHUN & 41 & $20.50 \%$ \\
\hline 25 - 30 TAHUN & 61 & $30.50 \%$ \\
\hline $30-35$ TAHUN & 53 & $26.50 \%$ \\
\hline$>35$ TAHUN & 45 & $22.50 \%$ \\
\hline TOTAL & 200 & $100.00 \%$ \\
\hline \multicolumn{3}{|l|}{ JENIS KELAMIN } \\
\hline LAKI-LAKI & 112 & $56.00 \%$ \\
\hline
\end{tabular}




\begin{tabular}{|l|r|r|}
\hline WANITA & 88 & $44.00 \%$ \\
\hline TOTAL & $\mathbf{2 0 0}$ & $\mathbf{1 0 0 . 0 0 \%}$ \\
\hline PEKERJAAN & 85 & $42.50 \%$ \\
\hline WIRASWASTA & 71 & $35.50 \%$ \\
\hline PEGAWAI SWASTA & 26 & $13.00 \%$ \\
\hline PEGAWAI NEGERI & 18 & $9.00 \%$ \\
\hline LAINNYA & $\mathbf{2 0 0}$ & $\mathbf{1 0 0 . 0 0 \%}$ \\
\hline TOTAL & 2013 &
\end{tabular}

Sumber : OlahanData Penelitian, 2013

Pengukuran kualitas pelayanan di PT PLN Persero Cabang Medan Baru Kotamadya Medan Sumatera Utara inidilakukan dengan memberikan kuesioner kepada 200 responden untuk mengisikuesioner sesuai dengan pendapat masing-masing responden tentang pelayananyang diterimanya dari yang didapatkan.

Berikut ini akan disajikan hasil temuan dalam penelitian ini mengenai kepuasan masyarakat akan kualitas pelayanan dan kepentingan yang diberikan PT PLN Persero Cabang Medan Baru Kotamadya Medan Sumatera Utara.

Tabel 2. Nilai Rata-rata Unsur Pelayanan PT PLN Persero Cabang Medan Baru

\begin{tabular}{|c|c|c|}
\hline No. & Unsur Pelayanan & Nilai Rata-rata \\
\hline 1 & Prosedur Pelayanan & 2,295 \\
\hline 2 & Persyaratan Pelayanan & 2,345 \\
\hline 3 & Kejelasan Petugas Pelayanan & 2,31 \\
\hline 4 & Kedisiplinan Petugas Pelayanan & 2,22 \\
\hline 5 & Tanggung Jawab Petugas Pelayanan & 2,335 \\
\hline 6 & Kemampuan Petugas Pelayanan & 2,57 \\
\hline 7 & Kecepatan Petugas Pelayanan & 2,18 \\
\hline 8 & Keadilan Mendapatkan Pelayanan & 2,195 \\
\hline 9 & Kesopanan dan Keramahan Petugas & 2,65 \\
\hline 10 & Kewajaran Biaya Pelayanan & 2,29 \\
\hline 11 & Kepastian Biaya Pelayanan & 2,22 \\
\hline 12 & Kepastian Jadwal Pelayanan & 2,355 \\
\hline 13 & Kenyamanan Lingkungan & 2,9 \\
\hline 14 & Keamanan Perlayanan & 2,375 \\
\hline \multicolumn{2}{|c|}{ Jumlah Nilai Kinerja Unsur } & 6648,00 \\
\hline \multicolumn{2}{|c|}{ Jumlah Nilai Rata-rata Kinerja Unsur } & 33,24 \\
\hline \multicolumn{2}{|c|}{ Jumlah nilai rata-rata tertimbang per unsur } & 2,36 \\
\hline \multicolumn{2}{|c|}{ IKM Unit Pelayanan } & 59,00 \\
\hline
\end{tabular}

Sumber: Olahan Data Penelitian, 2013 


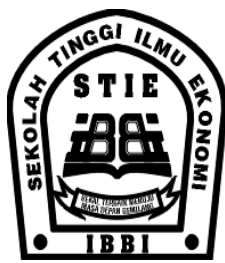

ISSN 1858-3199

JURNAL

MANAJEMEN BISNIS

STIE IBBI

Analisis tingkat kepentingan dan kinerja (Importance-Performance Analysis) dilakukan dengan membandingkan sejumlah sekor jawaban masing-masing item pertanyaan untuk mendapatkan persentase tingkat keseuaian antara kinerja dengan harapan. Berdasarkan analisis tingkat kepentingan dan tingkat kinerja maka diperoleh 2 variabel yaitu variabel $X$ untuk variabel tingkat kinerja dan variabel Y untuk variabel tingkat kepentingan masyarakat.

Tabel 3 Tingkat Kesesuaian Masyarakat

\begin{tabular}{|l|l|r|r|r|}
\hline \multirow{2}{*}{ No. Unsur } & \multicolumn{2}{c|}{ Total Bobot } & \multirow{2}{*}{ TKi } \\
\cline { 3 - 4 } & & Kinerja & Kepentingan & \\
\hline 1 & Prosedur Pelayanan & 459 & 624 & $73.56 \%$ \\
\hline 2 & Persyaratan Pelayanan & 469 & 618 & $75.89 \%$ \\
\hline 3 & Kejelasan Petugas Pelayanan & 462 & 645 & $71.63 \%$ \\
\hline 4 & Kedisiplinan Petugas Pelayanan & 444 & 643 & $69.05 \%$ \\
\hline 5 & Tanggung Jawab Petugas Pelayanan & 467 & 649 & $71.96 \%$ \\
\hline 6 & Kemampuan Petugas Pelayanan & 514 & 633 & $81.20 \%$ \\
\hline 7 & Kecepatan Petugas Pelayanan & 436 & 644 & $67.70 \%$ \\
\hline 8 & Keadilan Mendapatkan Pelayanan & 439 & 639 & $68.70 \%$ \\
\hline 9 & Kesopanan dan Keramahan Petugas & 530 & 637 & $83.20 \%$ \\
\hline 10 & Kewajaran Biaya Pelayanan & 458 & 629 & $72.81 \%$ \\
\hline 11 & Kepastian Biaya Pelayanan & 444 & 622 & $71.38 \%$ \\
\hline 12 & Kepastian Jadwal Pelayanan & 471 & 627 & $75.12 \%$ \\
\hline 13 & Kenyamanan Lingkungan & 580 & 601 & $96.51 \%$ \\
\hline 14 & Keamanan Pelayanan & 475 & 627 & $75.76 \%$ \\
\hline
\end{tabular}

Sumber : Olahan Data Penelitian, 2013

Diagram Importance Performance Analysis (IPA) merupakansuatu bangun yang dibagi atas empat bagian yang dibatasi oleh dua buah garisyang berpotongan tegak lurus pada titik $(X, Y)$. Titik $Y$ adalah rata-rata dari skorrata-rata tingkat kinerja terhadap seluruh faktor-faktor kepuasan. Hasil pengolahan data dengan menggunakan SPSS menghasilkan sebuah diagramImportance Performance Analysis (IPA) dapat dilihat pada gambar 5.1. Berdasarkan hasil olahan tersebut menunjukan bahwa:

a. Unsur kejelasan petugas pelayanan, kedisplinan petugas pelayanan, tanggung jawab petugas pelayanan, kecepatan petugas pelayanan dan keadilan mendapatkan pelayanan terletak pada kuadran I

b. Unsur kemampuan petugas pelayanan serta unsur keramahan dan kesopanan petugas pelayanan terletak pada kuadran II

c. Unsur prosedur pelayanan, persyaratan pelayanan, kewajaran biaya pelayanan, kepastian biaya pelayanan dan unsur kepastian jadwal pelayanan terletak pada kuadran III

d. Unsur kenyamanan lingkungan dan keamanan lingkungan terletak pada kuadran IV 


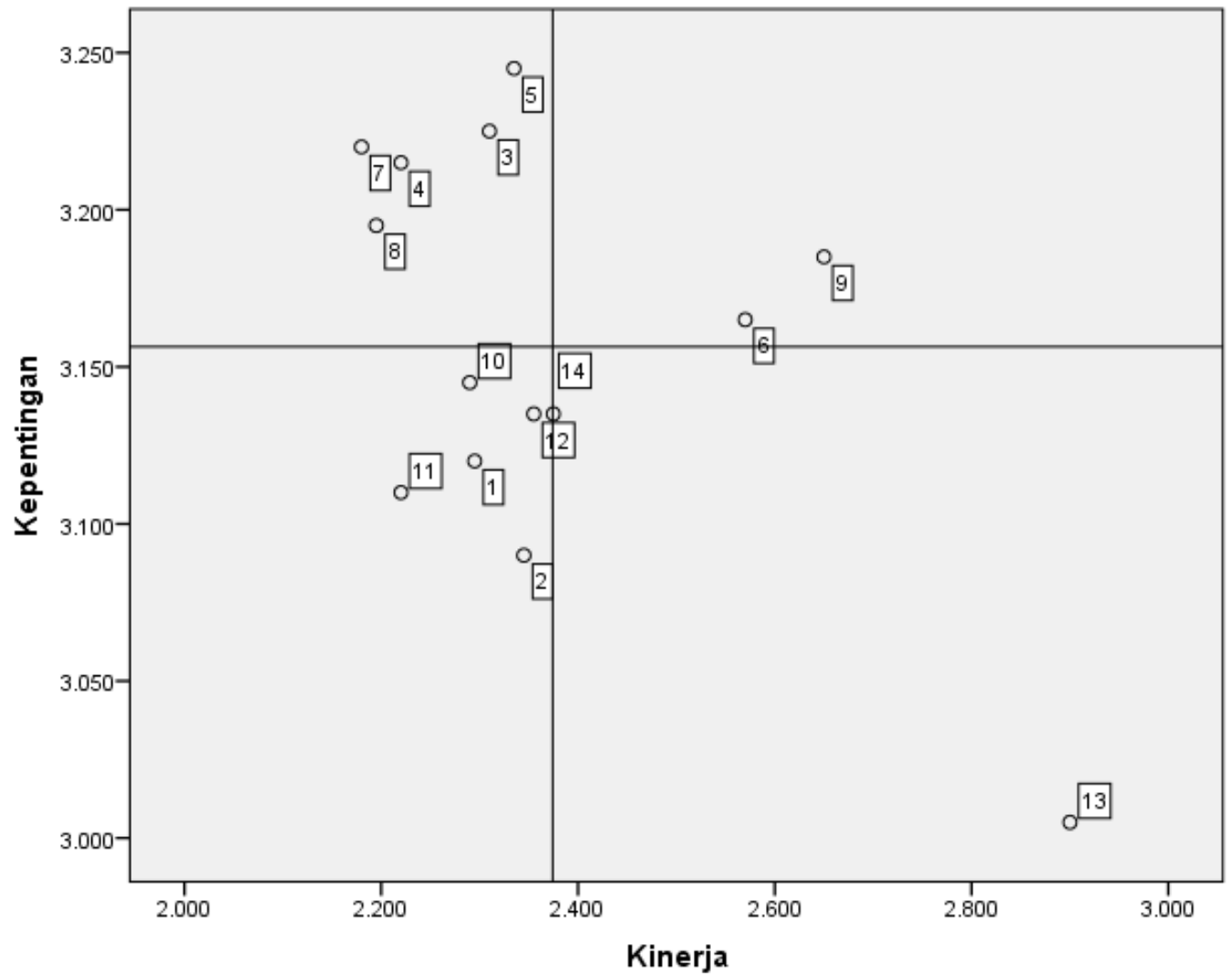

Gambar 3. Diagram Kartesius Tingkat Kepentingan dan Kinerja

\section{PEMBAHASAN}

Responden dalam penelitian ini sebanyak 200 orang yang merupakan masyarakat Kecamatan Medan Baru, mayoritas berjenis kelamin laki-laki, berumur 25-30 tahun dan bekerja sebagai wiraswasta.

Dari seluruh item pertanyaan pada kuesioner penilaian terhadap unsur pelayanan, diperoleh bahwa unsur kenyamanan lingkungan mendapatkan nilai rata-rata tertinggi sebesar 2,9 dan unsur kecepatan petugas pelayanan mendapatkan nilai rata-rata terendah sebesar 2,18.

Unsur kenyamanan lingkungan mendapatkan nilai rata-rata sebesar 2,9; sehingga diperoleh nilai Interval Konversi IKM sebesar 72,5 berada dalam interval konversi IKM 62,51-81,25 yang menunjukan bahwa masyarakat Kecamatan Medan Baru menyatakan puas akan kenyamanan lingkungan yang tersedia pada kantor pelayanan PT PLN Persero Cabang Medan Baru. Berdasarkan hasil pengamatan yang diperoleh di kantor pelayanan menunjukan bahwa kantor pelayanan memiliki tempat pelayanan yang nyaman dan bersih serta menyediakan fasilitas pendukung pelayanan.

Unsur kecepatan petugas pelayanan mendapatkan nilai rata-rata sebesar 2,18; sehingga nilai interval konversi IKM adalah 54,5 berada dalam interval IKM 43,76-62,50, yang menunjukan bahwa masyarakat Kecamatan Medan Baru menilai petugas kurang dapat menyelesaikan permasalahan listrik yang dialami masyarakat sesuai dengan waktu yang telah ditentukan oleh unit 


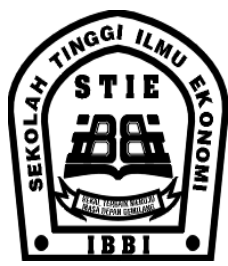

ISSN 1858-3199

JURNAL

MANAJEMEN BISNIS

STIE IBBI

penyelenggara pelayanan. Oleh karena itu, petugas pelayanan sering kurang dapat memberikan informasi mengenai waktu yang dibutuhkan dalam menyelesaikan keluhan masyarakat.

Kemudian dilakukan analisis indeks kepuasan masyarakat (IKM) atas pelayanan pada PT PLN Persero Cabang Medan Baru secara keseluruhan. Berdasarkan tabel 2, diperoleh angka indeks sebesar 2,36; sehingga nilai IKM setelah konversi sebesar 59,00 yang menunjukan mutu pelayanan bernilai C, yaitu kinerja mutu pelayanan PT PLN Persero Cabang Medan Baru kurang baik.Berdasarkan hasil tersebut, secara keseluruhan indeks kepuasan masyarakat atas pelayanan PT PLN Persero Cabang Medan Baru dapat dikatakan dalam kondisi yang kurang baik, sehingga kualitas pelayanan harus ditingkatkan karena masih banyak unsur pelayanan yang indeksnya menunjukkan kinerja yang kurang baik.

Dari 14 unsur pelayanan yang diukur; terdapat 1 unsur pelayanan yang baik dan mampu memuaskan masyarakat Kecamatan Medan Baru sedangkan sisanya 13 unsur pelayanan termasuk dalam kategori yang kurang baik pelayanannya sehingga perlu pembenahan. Unsur pelayanan yang termasuk dalam kategori baik adalah unsur kenyamanan lingkungan. Tiga belas unsur pelayanan yang termasuk dalam katergori kurang baik adalah unsur prosedur pelayanan;unsur persyaratan pelayanan;unsur kejelasan petugas pelayanan;unsur kedisiplinan petugas pelayanan;unsur tanggung jawab petugas pelayanan;unsur kemampuan petugas pelayanan;unsur kecepatan pelayanan;unsur keadilan mendapatkan pelayanan;unsur kesopanan dan keramahan petugas;unsur kewajaran biaya pelayanan;unsur kepastian biaya pelayanan;unsur kepastian jadwal pelayanan; dan unsur keamanan pelayanan.

Metode IPA yang digunakan untuk menentukan hubungan tingkat kinerja terhadap tingkat kepentingan tiap unsur yang terdapat dalam pelayanan yang diberikan. Berdasarkan pada diagram kartesius pada gambar 3, letak dari unsur-unsur kinerja/pelaksanaan aspek-aspek yang mempengaruhi kepuasan masyarakat Kecamatan Medan Baru terbagi menjadi empat bagian.

Berkaitan dengan hasil penelitian ini, yang diharapkan masyarakat untuk dipenuhi adalah yang menurut mereka sangat penting untuk diprioritaskan dalam upaya perbaikan karena kinerja dari aspek tersebut jauh dari harapan. Unsur-unsur yang berada diatas sumbu Y (nilai rata-rata kepentingan lebih besar dari 3,156) adalah apa yang menurut masyarakat sangat penting dalam rangka memenuhi kepuasannya. Oleh karena itu, unsur-unsur tersebut harus mendapat perhatian yang serius dari pihak manajemen PT PLN Persero Cabang Medan Baru. Unsur-unsur yang menurut masyarakat sangat penting guna memenuhi kepuasannya, kinerjanya bisa berada pada kondisi bagus dan atau sebaliknya. Unsur-unsur yang bagus dan sesuai dengan harapan masyarakat dan perlu dipertahankan kinerjanya (kuadran II), harus tetap dipertahankan kinerjanya. Sebaliknya, unsur-unsur yang menurut masyarakat sangat penting tetapi kinerjanya tidak memuaskan (kuadran I) seharusnya mendapatkan perhatian serius dan menjadi prioritas utama untuk segera diperbaiki kinerjanya.

\section{KESIMPULAN}

Berdasarkan uraian sebelumnya, maka dapat diambil kesimpulan sebagai berikut:

1. Dari 14 unsur pelayanan yang digunakan dalam penelitian ini sesuai dengan Kepmen PAN No. 25 tahun 2004 terdapat 1 unsur pelayanan dengan kategori baik yaitu unsur kenyamanan lingkungan. Selain itu, terdapat 13 unsur yang berkategori kurang baik dalam hal pelayanannya, ke-13 indikator tersebut adalah: unsur prosedur pelayanan;unsur persyaratan pelayanan;unsur kejelasan petugas pelayanan;unsur kedisiplinan petugas pelayanan;unsur tanggung jawab petugas pelayanan;unsur kemampuan petugas pelayanan;unsur kecepatan pelayanan;unsur keadilan mendapatkan pelayanan;unsur kesopanan dan keramahan 
petugas;unsur kewajaran biaya pelayanan;unsur kepastian biaya pelayanan;unsur kepastian jadwal pelayanan; dan unsur keamanan pelayanan.

2. Pengukuran nilai IKM secara keseluruhan menunjukkan kondisi yang kurang baik. Hal ini dapat dilihat dari kualitas pelayanan yang diukur berdasarkan unsur yang telah ditentukan menghasilkan nilai indeks interval konversi IKM sebesar 59,00 yang menunjukan mutu pelayanan bernilai C, yaitu kinerja mutu pelayanan PT PLN Persero Cabang Medan Baru kurang baik.

3. Hasil penilaian masyarakat Kecamatan Medan Baru terhadap pelayanan PT PLN Persero Cabang Medan Baru dengan menggunakan metode IPA diperoleh bahwa dua bagian penting yang patut mendapatkan prioritas perhatian dalam penanganannya yaitu unsur-unsur yang terdapat dalam kuadran I dimana dalam kuadran ini perlu mendapatkan prioritas utama untuk perbaikan pelayanan ke depan. Kemudian unsur yang terdapat dalam kuadran II yang merupakan aspek-aspek yang yang seharusnya tetap diperhatahankan kinerjanya untuk kedepannya. Berikut dua hal penting yang patut diperhatikan demi tercapainya kepuasan pelayanan bagi masyarakat Kecamatan Medan Baru yang bagus sesuai dengan hasil yang terdapat dalam analisis IPA adalah:

a. Kuadran I, dimana aspek-aspek yang terdapat dalam kuadran ini harus mendapatkan prioritas utama dalam upaya perbaikan dari manajemen PT PLN Persero Cabang Medan Baru demi kepentingan pelayanan publik. Hal ini didasarkan atas temuan bahwa menurut penilaian masyarakat bahwa unsur ini sangat penting namun kinerja yang diwujudkan dalam memberikan pelayanan masih banyak kelemahan dan kurang bagus. Aspek aspek yang termasuk dalam kuadran ini adalah

i. Unsur kejelasan petugas pelayanan,

ii. Unsur kedisplinan petugas pelayanan,

iii. Unsur tanggung jawab petugas pelayanan,

iv. Unsur kecepatan petugas pelayanan dan

v. Unsur keadilan mendapatkan pelayanan

b. Kuadran II, menujukkan bahwa aspek-aspek yang berada dalam kuadran ini perlu dipertahankan prestasinya dan apabila memungkinkan dapat lebih ditingkatkan lagi agar dapat memberikan pelayanan yang prima kepada masyarakat. Masyarakat menilai aspekaspek ini sudah memuaskan karena kinerjanya sesuai dengan harapan mereka. Aspekaspek yang termasuk dalam kuadran II adalah :

i. Unsur kemampuan petugas pelayanan

ii. Unsur keramahan dan kesopanan petugas pelayanan

\section{SARAN}

Demi menjaga kepercayaan masyarakat akan pelayanan PT PLN Persero Cabang Medan Baru yang berkualitas sudah selayaknya memperhatikan penilaian masyarakat yang yang menjadi responden dalam penelitian ini. Unsur-unsur yang harus dijadikan prioritas utama dalam perbaikan pelayanan disesuaikan dengan hasil temuan penelitian ini.Beberapa unsur tersebut adalah :

1. Unsur kejelasan petugas pelayanan

Petugas pelayanan PT PLN Persero Cabang Medan Baru telah memiliki kartu identitas dan tanggung jawab masing-masing sesuai dengan SOP yang berlaku. Akan tetapi, masih banyak kendala yang ditemukan masyarakat, yaitu petugas pelayanan yang susah dihubungi sewaktu masyarakat memperoleh masalah yang berkaitan dengan listrik PLN. Oleh karena itu, 
sebaiknya sistem penghargaan dan hukuman lebih diperjelas sehingga dapat memacu kinerja karyawan PT PLN Persero Cabang Medan Baru khususnya.

2. Unsur kedisplinan petugas pelayanan

Kedisiplinan petugas pelayanan menghasilkan ketepatan waktu dalam memberikan pelayanan kepada masuyarakat. Ketepatan waktu pelayanan ini meliputi pelayan teknis dan administrasi, kedua pelayanan ini harus berjalan seimbang dan terpadu. Manajemen PT PLN Persero Cabang Medan Baru telah memiliki SOP mengenai waktu pelayanan, namun ada proses sebelum keluhan masyarakat ditangani yaitu administrasi. Untuk itu baik tenaga penanganan keluhan maupun administrasi harus mampu menyelaraskan ritme pelayanan agar tidak sampai terjadi waktu tunggu penyelesaian keluhan yang lama.

3. Unsur tanggung jawab petugas pelayanan

Tanggung jawab petugas pelayanan telah dibuat dengan jelas sesuai dengan peraturan PT PLN Persero. Berdasarkan hasil survei yang dilakukan, hendaknya tanggung jawab ini juga diberitahukan kepada masyarakat, sehingga masyarakat dapat mengetahui secara jelas dan pasti mengenai tanggung jawab petugas pelayanan.

4. Unsur kecepatan petugas pelayanan

Sebaiknya petugas pelayanan dapat mengukur lamanya waktu penyelesaian keluhan berdasarkan pengalaman-pengalaman sebelumnya. Sehingga pada saat masyarakat menyampaikan keluhan, petugas dapat memberikan informasi kepada masyarakat mengenai lama waktu pelayanan yang dibutuhkan.

5. Unsur keadilan mendapatkan pelayanan

Sebaiknya setiap keluhan pelanggan dicatat dalam sebuah logbook atau sistem yang jelas. Berdasarkan pencatatan tersebut, pihak manajemen dapat memantau kinerja petugas pelayanan dalam memberikan pelayanan kepada masyarakat. Selain itu, diharapkan agar jangkaun atau cakupan pelayanan PT PLN Persero Cabang Medan Baru dapat dilakukan secara merata, sehingga masyarakat dapat merasakan keadilan yang sama terhadap semua kawasan yang terdapat dalam wilayah kerja PT PLN Persero Cabang Medan Baru.

\section{DAFTAR PUSTAKA}

Irawan,Hadi, 2002, "Prinsip Kebiasaan Pelanggan”, Penerbit: PT Alexmedia Komputindo, Jakarta.

Kotler,Philip, 2000, "Manajemen Pemasaran di Indonesia: Analisa, Perencanaan, Implementasi dan Pengendalian”, Terjemahan A.B. Susanto, Penerbit PT Salemba Empat, Jakarta

Rahmayanty, Nina, 2010,"Manajemen Pelayanan Prima”,Penerbit Graha Ilmu, Yogyakarta

Rangkuti,Freddy, 2003, "Measuring Customer Statification”, Penerbit PT Gramedia Pustaka Utama, Jakarta

Ratminto \& Atik Septi Winarsih, 2010,“Manajemen Pelayanan;Pengembangan Model Konseptual, Penerapan Citizen's Charter Dan Standar Pelayanan Minimal”,Penerbit Pustaka Pelajar, Yogyakarta.

Simammora, B., 2004,“Panduan Riset Perilaku konsumsen”,Penerbit PT Gramedia, Jakarta

Sugiyono, 2007, Metode Penelitian Kuantitatif, Kualitatif, R\&D, Penerbit Alfabeta, Bandung

Sumarni, Murti, 2002, "Manajemen Pemasaran Bank”, Penerbit Liberty, Yogyakarta.

Tjiptono, Fandy, 2000, “Strategi Manajemen”, Penerbit ANDI Offset, Yogyakarta

Tjiptono, Fandy,2005, "Pemasaran Jasa”,Cetakan Pertama, Penerbit Bayu Media Publishing, Surabaya.

Tjiptono, Fandy dan Gregorius Chandra, 2005, “Service, Quality \& Satisfaction”, Penerbit ANDI, Yogyakarta 


\section{UCAPAN TERIMA KASIH}

Penulis mengucapkan terima kasih kepada Dirjen DIKTI Kemendikbud RI yang telah memberikan kesempatan melakukan Penelitian Dosen Pemula dengan sumber dana DIPA Tahun Anggaran 2013; masyarakat dan apartur pemerintahan Kecamatan Medan Baru; PT PLN (Persero) Cabang Medan Baru dan LPPM STIE IBBI Medan. 


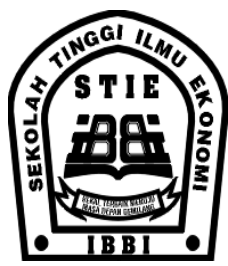

ISSN 1858-3199

JURNAL

MANAJEMEN BISNIS

STIE IBBI

\title{
PENGARUH KREDIT PERBANKAN, INVESTASI ASING LANGSUNG DAN NILAI TUKAR TERHADAP PERTUMBUHAN EKONOMI INDONESIA
}

\author{
Ripka Seriidahnaita Ginting \\ Dosen Tetap STIE IBBI Medan
}

\begin{abstract}
ABSTRAK / ABSTRACT
Penelitian ini bertujuan menguji pengaruh kredit perbankan, investasi asing langsung dan nilai tukar Indonesia terhadap pertumbuhan ekonomi Indonesia tahun 1990 - 2013. Penelitian ini menggunakan model regresi linier berganda. Kesimpulan yang dapat diambil dari hasil pengujian yaitu secara parsial kredit perbankan berpengaruh negatif dan tidak signifikan terhadap pertumbuhan ekonomi, sedangkan investasi asing langsung di Indonesia berpengaruh positif dan signifikan terhadap pertumbuhan ekonomi serta nilai tukar berpengaruh positif dan signifikan terhadap pertumbuhan ekonomi selama kurun waktu 1990 - 2013. Selain itu, secara simultan kredit perbankan, investasi asing langsung di Indonesia dan berpengaruh nilai tukar berpengaruh positif dan signifikan terhadap pertumbuhan ekonomi Indonesia.
\end{abstract}

Kata kunci : kredit perbankan, investasi asing langsung, nilai tukar, pertumbuhan ekonomi

This study is purposed, to test the effects of foreign direct investment in Indonesia and towards economic growth during year $1990-2013$. The testing equipment of this study is multiple linier regression model. The conclusion that we can take from the test results are, partially the amount of bank credit is negative and not significant effect towards economic growth. The exchange rate and foreign direct investment in Indonesia has an positive and significant effect towards economic growth during year 1990 - 2013. Simultaneously, the amount of bank credit, exchange rate and foreign direct investment in Indonesia has an effect towards economic growth. But the only exchange rate has an dominant effect towards gross domestic product during year 1990-2013

Key Words : bank credit, foreign direct investment, exchange rate, economic growth 

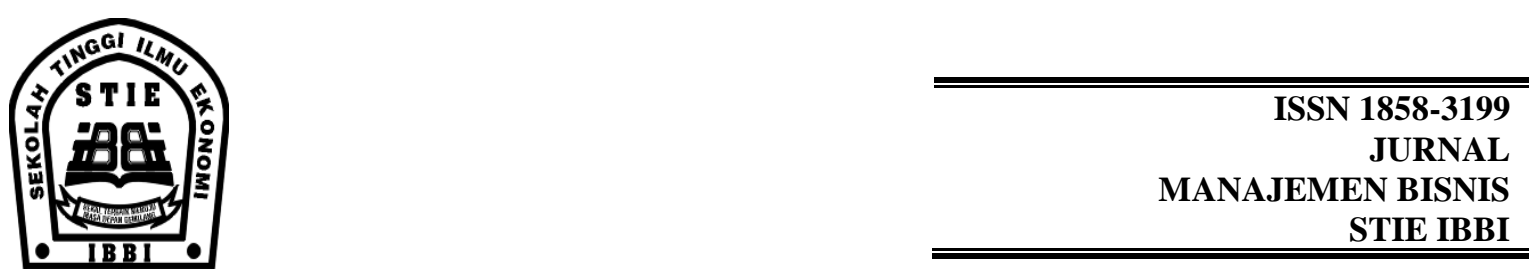

\section{PENDAHULUAN}

Peranan perbankan dalam pertumbuhan ekonomi merupakan hal yang sangat penting karena berfungsi sebagai lembaga intermediasi antara pemilik dana dan peminjam. Selain itu sektor perbankan juga memiliki peranan penting untuk menggerakkan perekonomian dengan memberikan kredit kepada sektor riil dan jasa. Berkembangnya sektor riil dan jasa akan menghasilkan output berupa barang dan jasa yang digunakan untuk memenuhi konsumsi masyarakat serta memberikan kontribusi kepada perkembangan produk domestik bruto. Sejumlah penelitian menunjukkan bahwa penyaluran kredit mendorong pertumbuhan ekonomi suatu negara. Goldsmith (1969), Mc Kinon dan Shaw (1973) menyatakan bahwa dana berlebih (surplus fund) yang disalurkan secara efisien bagi unit yang mengalami defisit akan meningkatkan kegiatan produksi. Selanjutnya kegiatan tersebut akan meningkatkan pertumbuhan ekonomi. (Pratama 2010).

Pada umumnya di negara-negara berkembang khususnya Indonesia, sumber pembiayaan dalam dunia usaha didominasi oleh penyaluran kredit perbankan yang diharapkan mampu mendorong pertumbuhan ekonomi Indonesia. Pemberian kredit merupakan aktivitas bank yang dapat menghasilkan keuntungan, namun risiko yang terbesar yang terjadi dalam bank juga bersumber dari pemberian kredit.

Penyaluran kredit memungkinkan masyarakat untuk melakukan investasi, distribusi, dan juga konsumsi barang dan jasa, mengingat semua kegiatan investasi, distribusi, dan konsumsi selalu berkaitan dengan penggunaan uang. Kelancaran kegiatan investasi, distribusi, dan konsumsi ini tidak lain adalah kegiatan pembangunan perekonomian masyarakat. Melalui fungsi ini bank berperan sebagai Agent of Development (Susilo, Triandaru, dan Santoso, 2006).

Keberhasilan pembangunan ekonomi suatu negara dapat diukur dari tingkat atau laju pertumbuhan ekonomi negara tersebut. Pertumbuhan ekonomi merupakan salah satu indikator penting dalam keberhasilan pembangunan ekonomi bagi suatu negara. Dalam rangka meningkatkan pertumbuhan ekonomi, maka pemerintah menerapkan beberapa kebijakan, salah satunya adalah dengan menerapkan kebijakan investasi asing langsung (foreign direct investment)

Indonesia menganut sistem perekonomian terbuka dimana pergerakan arus modal masuk dan keluarnya dana asing tidak dapat dihambat, sehingga pemerintah berusaha meningkatkan iklim investasi di Indonesia dengan cara menarik minat investor asing untuk memilih investasi yang bersifat direct investment. Sejak terjadinya krisis moneter pada pertengahan tahun 1997, ekonomi Indonesia mengalami keterpurukan dimana keadaan perekonomian semakin memburuk dan kesejahteraan rakyat semakin menurun. Selain itu krisis moneter juga mengakibatkan besarnya pembengkakan utang luar negeri pemerintah, sehingga solusi yang dianggap dapat diandalkan untuk mengatasi kendala tersebut adalah dengan mendatangkan modal dari luar negeri yang salah satunya adalah arus modal swasta berupa investasi swasta langsung (PMA).

Modal asing ini dapat diberikan kepada pemerintah maupun pihak swasta. Pemerintah dapat mengupayakan sumber dana dari luar negeri berupa investasi asing langsung atau (foreign direct investment). Sumber pembiayaan yang berasal dari penanaman modal asing langsung merupakan pembiayaan luar negeri yang paling potensial dalam menjamin keberlangsungan pembangunan jangka panjang karena hal ini akan diikuti dengan transfer of technology, know- how, management skill, resiko usaha relatif kecil dan lebih profitable (Mudara, 2011). Selain itu, masuknya modal asing juga dapat menggerakkan kegiatan ekonomi yang lesu karena kurangnya modal bagi pelaksanaan pembangunan ekonomi. Modal asing ini selain sebagai perpindahan modal juga dapat memberikan kontribusi positif melalui aliran industrialisasi dan modernisasi.

Periode 1990-an, salah satu penyebab pertumbuhan ekonomi Indonesia relatif lambat, karena masih belum maksimalnya kegiatan investasi asing langsung. Pasca orde baru menyatakan 


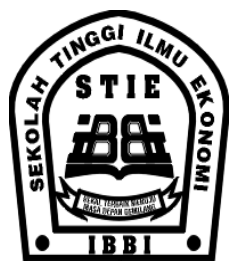

ISSN 1858-3199

JURNAL

MANAJEMEN BISNIS

STIE IBBI

bahwa investasi asing langsung, faktor penting bagi target pertumbuhan dan kemajuan ekonomi yang tepat tiap sektor untuk jangka panjang. Perubahan struktural, perkembangan teknologi, diversifikasi produk, dan pertumbuhan ekspor tiap sektor di Indonesia sebagian besar karena masuknya investasi asing langsung Indonesia dewasa ini (Tambunan, 2006)

Krisis ekonomi di Indonesia pada tahun 1997 juga menyebabkan terjadinya inflasi dan melemahnya nilai tukar rupiah. Merosotnya nilai rupiah menyebabkan jumlah utang luar negeri menjadi bertambah karena meningkatnya perbedaan nilai mata uang rupiah dengan mata uang asing khususnya nilai mata uang dollar Amerika (US\$) sehingga beban utang luar negeri yang akan dibayarkan menjadi bertambah besar. Selain itu biaya produksi bertambah besar karena harus mengimpor bahan baku dan mengakibatkan mahalnya harga jual di dalam negeri, sedangkan impor barang jadi atau barang akhir berdampak pada berkurangnya kontribusi produksi dalam negeri dari beberapa sektor pada produk domestik bruto.

Berdasarkan latar belakang di atas, maka peneliti tertarik untuk meneliti tentang pengaruh tingkat kredit perbankan, investasi asing langsung, nilai tukar rupiah terhadap pertumbuhan ekonomi tahun 1990 - 2013.

\section{TINJAUAN LITERATUR Kredit Perbankan}

Kredit berasal dari kata credere yang berarti kepercayaan. Tujuan pemberian kredit dari pihak bank yaitu untuk memperoleh keuntungan yang aman, sehingga pada saatnya masyarakat peminjam dana di bank dapat memperoleh kembali simpanannya berikut bunga tanpa dikuatirkan oleh adanya kredit macet. (Rimsky K, 2002). Kredit memiliki fungsi sebagai berikut :

1. Meningkatkan daya guna uang

Para pemilik uang / modal baik secara langsung atau melalui penyimpanan dana di bank dapat meminjamkan uangnya kepada perorangan atau perusahaan-perusahaan untuk meningkatkan usahanya

2. Meningkatkan daya guna dan peredaran barang

Dengan pemberian kredit, pengusaha yang kesulitan dalam kegiatan produksi dapat terbantu untuk memproses bahan baku menjadi barang jadi

3. Meningkatkan peredaran dan lalu lintas uang

Kredit uang yang disalurkan melalui rekening giro dapat menciptakan pembayaran dengan menggunakan uang giral seperti cek, bilyet giro, dan lainnya yang sejenis.

4. Sebagai alat stabilitas ekonomi

Kredit dapat digunakan sebagai alat pengendalian ekonomi. Dalam keadaan inflasi pemerintah dapat menerapkan kebijakan uang ketat (tight money policy) dengan membatasi pemberian kredit. Sebaliknya dalam keadaan ekonomi yang lesu karena deflasi, pemerintah dapat melonggarkan kebijakan pemberian kredit sehingga akan menimbulkan kegiatan usaha.

5. Meningkatkan kegairahan berusaha

Pihak - pihak yang usahanya terhambat karena kekurangan modal dapat meningkatkan usahanya melalui bantuan kredit yang diberikan oleh bank

6. Meningkatkan pemerataan pendapatan

Dengan pemberian kredit, perusahaan - perusahaan dapat meningkatkan usaha dan dapat mendirikan proyek baru yang akan membutuhkan tenaga kerja.

7. Meningkatkan hubungan international

Pengusaha di dalam negeri dapat pula memperoleh kredit baik secara langsung (offshore loan) maupun tidak langsung (two step loan). 


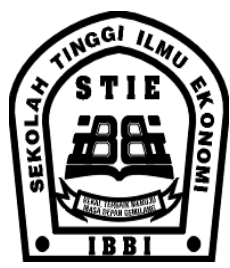

ISSN 1858-3199

JURNAL

MANAJEMEN BISNIS

STIE IBBI

Kredit Dari Segi Penggunaannya

Kredit bila dilihat dari segi penggunaannya dapat dibagi menjadi tiga, yaitu (Ditria, Vivian dan Widjaja, 2008) :

1. Kredit modal kerja yaitu kredit berjangka waktu pendek yang diberikan oleh bank kepada perusahaan yang membutuhkan modal kerja untuk memperlancar kegiatan operasional perusahaan.

2. Kredit investasi yaitu kredit ini adalah kredit jangka menengah atau panjang yang diberikan oleh bank kepada pihak perusahaan yang membutuhkan dana untuk investasi atau penanaman modal.

3. Kredit Konsumsi yaitu kredit yang diberikan dengan maksud untuk memperlancar kegiatan yang sifatnya konsumtif seperti kredit pemilikan rumah, kredit pemilikan kendaraaan bermotor, credit card, dan kredit konsumtif lainnya. Jangka waktu kredit konsumsi ini bisa jangka pendek, menengah, maupun jangka panjang.

\section{Investasi Asing Langsung}

Istilah penanaman modal dalam bahasa asing yaitu Investment. Peranan modal asing atau investasi asing digunakan dalam artian yang berbeda. Penanaman modal asing adalah kegiatan menanam modal untuk melakukan usaha di wilayah negara Republik Indonesia yang dilakukan oleh penanam modal asing, baik yang menggunakan modal asing sepenuhnya maupun yang berpatungan dengan penanam modal dalam negeri (Undang-Undang RI Nomor 25 Tahun 2007 dalam Mudara, 2011).

Investasi asing (Foreign Investment) dibagi ke dalam dua komponen yaitu; Investasi langsung (Direct Investment) dan investasi portofolio (Portofolio Investment). Investasi langsung (Direct Investment) melalui para investor berpartisipasi dalam manajemen perusahaan untuk memperoleh imbalan dari modal yang mereka tanamkan. Sedangkan investasi portofolio yaitu pembelian saham dan obligasi yang semata-mata tujuannya untuk memperoleh hasil dari dana yang ditanamkan. Investasi asing langsung (FDI) biasanya melibatkan kepemilikan secara sebagian atau keseluruhan perusahaan di negara yang menjadi tujuan investasi sehingga dapat memberikan peluang pendayagunaan modal dan tenaga kerja bagi negara tujuan investasi.

Meningkatnya investasi langsung di Indonesia memberikan variasi arah pembangunan perekonomian. Pemilihan investasi asing lebih rasional terutama dari sisi lebih rendahnya tingkat resiko. Investasi asing langsung selain sifatnya yang permanen atau jangka panjang, juga memunculkan transfer teknologi, transfer keterampilan manajemen, serta menciptakan lapangan pekerjaan.

\section{Nilai Tukar (Kurs)}

Kurs merupakan salah satu harga yang terpenting dalam perekonomian terbuka karena memiliki pengaruh besar bagi neraca transaksi berjalan maupun variabel-variabel makro ekonomi yang lain. Ada dua pendekatan yang digunakan untuk menentukan nilai tukar mata uang yaitu pendekatan moneter dan pendekatan pasar.

Dalam pendekatan moneter, nilai tukar mata uang didefinisikan sebagai harga dimana mata uang asing diperjualbelikan terhadap mata uang domestik dan harga tersebut berhubungan dengan penawaran dan permintaan uang. Naik turunnya nilai tukar mata uang atau kurs valuta asing bisa terjadi dengan berbagai cara, yaitu dengan cara pemerintah suatu negara menganut sistem managed floating exchange rate, atau disebabkan karena tarik menarik kekuatan-kekuatan penawaran dan 


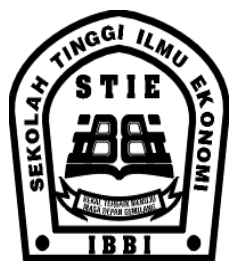

ISSN 1858-3199

JURNAL

MANAJEMEN BISNIS

STIE IBBI

permintaan di dalam pasar (market mechanism). Perubahan nilai tukar mata uang tersebut bisa terjadi karena 4 (empat) hal, yaitu:

a. Depresiasi (depreciation) yaitu penurunan harga mata uang nasional terhadap mata uang asing lainnya, yang terjadi karena tarik menariknya kekuatan supply and demand di dalam pasar (market mechanism).

b. Appresiasi (appreciation), adalah peningkatan harga mata uang nasional terhadap berbagai mata uang asing lainnya, yang terjadi karena tarik menariknya kekuatan supply dan demand di dalam pasar (market mechanism).

c. Devaluasi (devaluation), adalah penurunan harga mata uang nasional terhadap berbagai mata uang asing lainnya yang dilakukan secara resmi oleh pemerintah suatu negara.

d. Revaluasi (revaluation), adalah peningkatan harga mata uang nasional terhadap berbagai mata uang asing lainnya yang dilakukan secara resmi oleh pemerintah suatu negara.

Nilai tukar disebut kurs valuta dalam berbagai transaksi ataupun jual beli valuta asing. Terdapat 4 (empat) jenis yaitu (Dornbusch dan Fischer, 1992):

a. Selling Rate (kurs jual), adalah kurs yang ditentukan oleh suatu Bank untuk penjualan valuta asing tertentu pada saat tertentu

b. Middle Rate (kurs tengah), adalah kurs tengah antara kurs jual dan kurs beli valuta asing terhadap mata uang nasional, yang ditetapkan oleh bank sentral pada suatu saat tertentu.

c. Buying Rate (kurs beli), adalah kurs yang ditentukan oleh suatu bank untuk pembelian valuta asing tertentu pada saat tertentu.

d. Flat Rate (kurs flat), adalah kurs yang berlaku dalam transaksi jual beli bank notes dan traveller chaque, di mana dalam kurs tersebut sudah diperhitungkan promosi dan biaya-biaya lainya.

\section{Pertumbuhan Ekonomi}

Teori pertumbuhan ekonomi didefinisikan sebagai penjelasan mengenai faktor-faktor yang menentukan kenaikan output perkapita dalam jangka panjang dan penjelasan mengenai interaksi faktor-faktor tersebut satu sama lain sehingga terjadi proses pertumbuhan (Boediono, 1999). Salah satu teori pertumbuhan ekonomi yang digunakan yaitu Teori Harrod-Domar. Dalam teorinya, pengeluaran investasi tidak hanya mempunyai pengaruh terhadap permintaan aggregat tetapi juga terhadap penawaran aggregat melalui pengaruhnya terhadap kapasitas produksi. Selain itu Harrod Domar mengatakan bahwa setiap penambahan stok kapital masyarakat akan meningkatkan pula kemampuan masyarakat untuk menghasilkan output yang potensial. Hubungan antara stok kapital masyarakat dan output potensial adalah proporsional, apabila stok kapital naik dua kali lipat maka output potensial juga naik dua kali lipat. Semakin besar investasi maka semakin besar tambahan ouput potensial.

Menurut Kuznets (dalam Todaro, 2000) definisi pertumbuhan ekonomi suatu negara adalah kenaikan kapasitas dalam jangka panjang dari negara yang bersangkutan untuk menyediakan berbagai barang ekonomi kepada penduduknya. Kenaikan kapasitas itu dimungkinkan oleh adanya kemajuan teknologi, institusional (kelembagaan) dan ideologis terhadap berbagai tuntutan keadaan yang ada. Profesor Kuznets megemukakan 6 (enam) karakteristik atau ciri proses pertumbuhan ekonomi yang bisa ditemui pada hampir semua negara yaitu : tingkat pertumbuhan output per kapita dan pertumbuhan penduduk yang tinggi, tingkat kenaikan total produktivitas faktor yang tinggi, tingkat transformasi struktural ekonomi yang tinggi, tingkat transformasi sosial dan ideologi yang tinggi serta adanya kecenderungan negara-negara yang mulai atau yang sudah maju perekonomiannya untuk berusaha merambah bagian-bagian dunia lainnya sebagai daerah pemasaran dan 


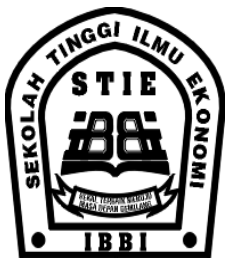

ISSN 1858-3199

JURNAL

MANAJEMEN BISNIS

STIE IBBI

sumber bahan baku yang baru, terbatasnya penyebaran pertumbuhan ekonomi yang hanya mencapai sekitar sepertiga bagian penduduk dunia.

\section{KERANGKA BERPIKIR}

Pertumbuhan ekonomi merupakan salah satu indikator yang amat penting dalam menilai kinerja suatu perekonomian, Ekonomi dikatakan mengalami pertumbuhan apabila produksi barang dan jasa meningkat dari tahun sebelumnya. Pertumbuhan ekonomi menunjukkan sejauh mana aktivitas perekonomian dapat menghasilkan tambahan pendapatan atau kesejahteraan masyarakat pada periode tertentu. Pertumbuhan ekonomi suatu negara atau suatu wilayah yang terus menunjukkan peningkatan menggambarkan bahwa perekonomian negara atau wilayah tersebut berkembang dengan baik (Amir, 2007).

Perekonomian suatu negara digerakkan antara lain oleh sektor riil dan jasa, dimana untuk berkembang dibutuhkan suntikan dana sebagai investasi maupun modal kerja. Terdapat beberapa cara untuk mendapatkan dana dan salah satu yang paling umum adalah kredit melalui perbankan. Kredit melalui perbankan diharapkan mampu mendorong perkembangan investasi dalam negeri baik di sektor riil maupun jasa yang akan menghasilkan output bagi pemenuhan kebutuhan konsumsi masyarakat, membuka lapangan pekerjaan dan pada akhirnya akan mendorong pertumbuhan ekonomi.

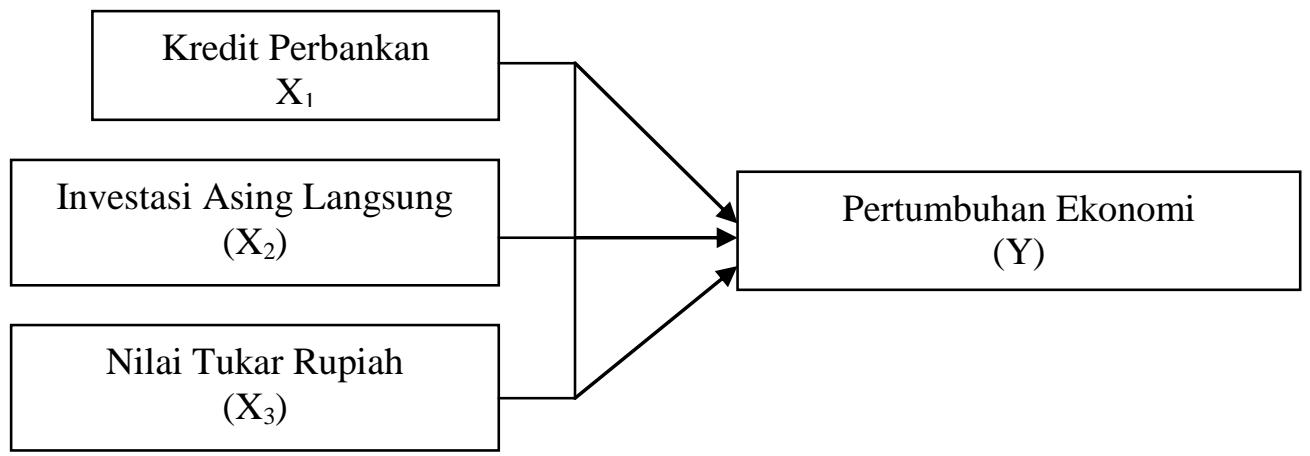

Gambar : Kerangka Berpikir

Masuknya modal asing juga dapat menggerakkan kegiatan ekonomi yang lesu karena kurangnya modal bagi pelaksanaan pembangunan ekonomi. Modal asing ini selain sebagai perpindahan modal juga dapat memberikan kontribusi positif melalui aliran industrialisasi dan modernisasi. peningkatan investasi ini akan berdampak pada penggunaan sumber daya alam dan manusia yang semakin meningkat sehingga produksi nasional dapat ditingkatkan dan pada akhirnya akan mempercepat laju pertumbuhan ekonomi.

Peningkatan atau penguatan nilai rupiah terhadap mata uang asing khususnya nilai mata uang dollar Amerika (US\$) menyebabkan beban utang luar negeri yang akan dibayarkan menjadi berkurang sehingga sumber dana yang dimiliki baik yang berasal dari dalam negeri maupun yang berasal dari investasi asin langsung dapat digunakan secara maksimal bagi perkembangan perekonomian khususnya untuk biaya produksi di segala sektor sektor riil mapun jasa sehingga memberikan kontribusi produksi dalam negeri dari beberapa sektor pada produk domestik bruto yang pada akhirnya akan meningkatkan pertumbuhan ekonomi.

Berdasarkan kerangka berpikir di atas maka hipotesis yang digunakan sebagai berikut: 


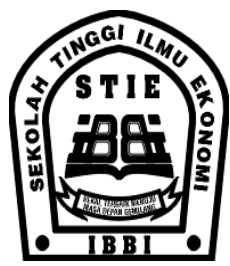

ISSN 1858-3199

JURNAL

MANAJEMEN BISNIS

STIE IBBI

$\mathrm{H}_{1}$ : Kredit perbankan berpengaruh positif dan signifikan terhadap pertumbuhan ekonomi

$\mathrm{H}_{2}$ : Investasi asing langsung berpengaruh positif dan signifikan terhadap pertumbuhan ekonomi

$\mathrm{H}_{3}$ : Nilai tukar rupiah berpengaruh positif dan signifikan terhadap pertumbuhan ekonomi

\section{METODOLOGI PENELITIAN}

Data yang digunakan dalam penelitian ini adalah data sekunder yang diperoleh dari lembaga atau instansi antara lain Bank Indonesia, Badan Pusat Statistik, Badan Koordinasi Penanaman Modal. Adapun data yang digunakan adalah :

1. Data kredit perbankan tahun 1990 - 2013, data kredit perbankan yang dipergunakan adalah data total kredit perbankan (data kredit investasi tahun 1990 - Oktober 2013, data kredit konsumsi tahun 1990 - November 2013 , kredit modal kerja tahun 1990 - November 2013) yang dikeluarkan oleh Bank Indonesia dengan satuan milyar rupiah

2. Data nilai tukar rupiah terhadap US \$ tahun 1990 - 2013 berdasarkan kurs tengah yang dinyatakan dalam rupiah

3. Data investasi asing langsung tahun 1990 - 2013, data yang digunakan adalah data penanaman modal asing yang dinyatakan dalam US \$ Juta

4. Data pertumbuhan ekonomi tahun 1990 - 2013 yang dinyatakan dalam persen

Teknik analisis data yang digunakan adalah analisis regresi berganda. Terdapat beberapa masalah yang muncul pada saat mengestimasi suatu model dengan sejumlah data sehinggga sebelum melakukan interpretasi terhadap hasil regresi dari model yang digunakan maka terlebih dahulu dilakukan pengujian asumsi klasik yang terdiri dari autokorelasi, normalitas, heteroskedastisitas dan multikolinieritas (Gujarati, 2001). Penarikan kesimpulan atas hipotesis dilakukan dengan cara Uji t dan uji $\mathrm{F}$ pada level signifikansi $5 \%$. Keseluruhan pengelolaan data menggunakan software Eviews.

\section{HASIL PENELITIAN}

Dari hasil pengolahan data untuk pengujian asumsi klasik, diperoleh hasil sebagai berikut :

\section{a. Multikolinieritas}

Nilai $R$ square utk auxiliary regression pada masing-masing variabel bebas diperoleh yaitu $\mathrm{R}^{2}$ $=0.450930 ; \mathrm{R}^{2}=0.431803 ; \mathrm{R}^{2}=0.076819$ yang lebih kecil dari nilai $\mathrm{R}$ square yang diperoleh dari regresi model awal sebesar $\mathrm{R}^{2}=0.666258$. Sehingga dapat disimpulkan tidak terjadi Multikolinieritas pada masing-masing variabel bebas. Hasil atau ouput dari olahan data Eviews dapat dilihat pada tabel berikut ini :

Tabel 1. Uji Multikolinieritas

\begin{tabular}{llll}
$\begin{array}{l}\text { Dependent Variable: LNTR } \\
\text { Method: Least Squares } \\
\text { Sample: } 19902013\end{array}$ & & & \\
Included observations: 24 & & & \\
\hline \hline R-squared & 0.450930 & Mean dependent var & 8.673001 \\
Adjusted R-squared & 0.398637 & S.D. dependent var & 0.681057 \\
S.E. of regression & 0.528143 & Akaike info criterion & 1.677570 \\
Sum squared resid & 5.857642 & Schwarz criterion & 1.824827 \\
Log likelihood & -17.13085 & F-statistic & 8.623230 \\
Durbin-Watson stat & 0.357328 & Prob(F-statistic) & 0.001845 \\
\hline \hline
\end{tabular}

Sumber: Hasil olah data (2013) 
Dependent Variable: LFDI

Tabel 2.

Method: Least Squares

Sample: 19902013

Included observations: 24

\begin{tabular}{lrll}
\hline \hline R-squared & 0.431803 & Mean dependent var & 8.704623 \\
Adjusted R-squared & 0.377689 & S.D. dependent var & 0.893545 \\
S.E. of regression & 0.704888 & Akaike info criterion & 2.254914 \\
Sum squared resid & 10.43422 & Schwarz criterion & 2.402170 \\
Log likelihood & -24.05896 & F-statistic & 7.979504 \\
Durbin-Watson stat & 0.613946 & Prob(F-statistic) & 0.002644 \\
\hline \hline
\end{tabular}

Sumber: Hasil olah data (2013)

Tabel 3.

Dependent Variable: LCRD

Method: Least Squares

Sample: 19902013

Included observations: 24

\begin{tabular}{lrll}
\hline \hline R-squared & 0.076819 & Mean dependent var & 8.092470 \\
Adjusted R-squared & -0.011103 & S.D. dependent var & 0.925686 \\
S.E. of regression & 0.930811 & Akaike info criterion & 2.810947 \\
Sum squared resid & 18.19458 & Schwarz criterion & 2.958204 \\
Log likelihood & -30.73136 & F-statistic & 0.873714 \\
Durbin-Watson stat & 0.807398 & Prob(F-statistic) & 0.432029 \\
\hline \hline
\end{tabular}

Sumber: Hasil olah data (2013)

\section{b. Autokorelasi}

Tabel 5. Uji Autokorelasi

Breusch-Godfrey Serial Correlation LM Test:

\begin{tabular}{llll}
\hline \hline F-statistic & 1.290935 & Probability & 0.299288 \\
Obs*R-squared & 3.010653 & Probability & 0.221945 \\
\hline \hline
\end{tabular}

Sumber : Hasil olah data (2013)

Test Equation:

Dependent Variable: RESID

Method: Least Squares

Presample missing value lagged residuals set to zero

Dilihat dari nilai Obs*R-squared sebesar 3,010653 dengan probabilitas sebesar 0,221945 yang tidak signifikan dan $X^{2}$ tabel yang disesuaikan dengan jumlah lag $=2$ dan $\alpha=5 \%$ sebesar 7,81 maka dapat disimpulkan model bebas dari masalah serial korelasi.

\section{c. Normalitas}

Berdasarkan gambar di atas dapat dilihat bahwa besarnya nilai Jarque Berra normality test statistics sebesar 1,197327 kemudian dibandingkan dengan nilai $\mathrm{X}^{2}$ tabel dengan signifikansi 0,05 serta derajat kebebasan (degrre of freedom) $\mathrm{df}=\mathrm{k}-1=4-1=3$ yaitu 7,81 maka dapat disimpulkan residual $\mu$ (nilai rata-rata dari faktor penggangu) berdistribusi normal. 
Gambar 1. Uji Normalitas
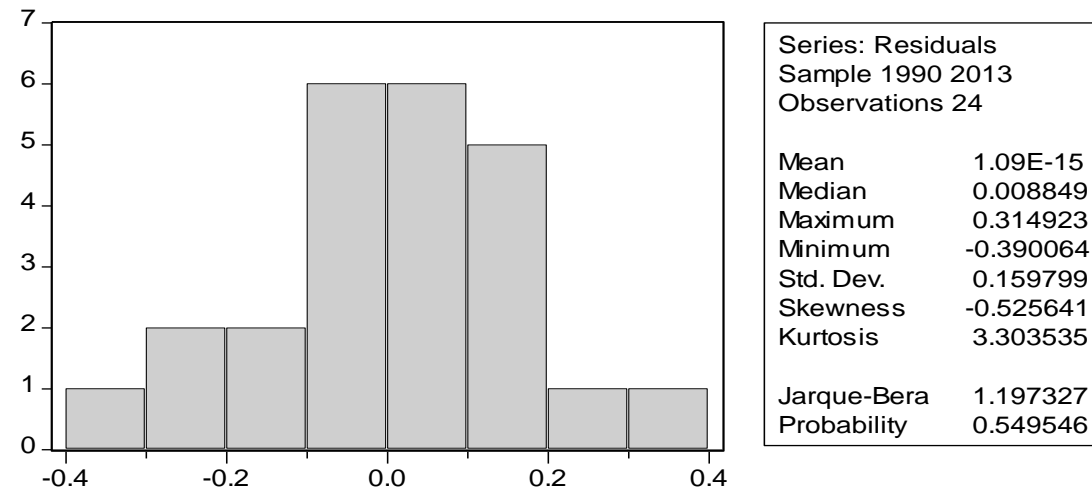

Sumber : Hasil olah data (2013)

\section{d. Heteroskedastisitas}

Tabel 6. Uji Heteroskedastisitas

White Heteroskedasticity Test:

\begin{tabular}{llll}
\hline \hline F-statistic & 0.496609 & Probability & 0.802191 \\
Obs*R-squared & 3.579227 & Probability & 0.733401 \\
\hline \hline
\end{tabular}

Test Equation:

Dependent Variable: RESID^2

Method: Least Squares

Sample: 19902013

Included observations: 24

Sumber : Hasil olah data (2013)

Dari hasil uji heteroskedastisitas pada tabel 7 diatas dapat dilihat bahwa angka probabilitas Obs*R-squared sebesar 0,737420 yang tidak signifikan serta nilai Obs*R-squared sebesar 3,549144 lebih kecil dari $\mathrm{X}^{2}$ tabel 7,81 dengan $\alpha=5 \%$ maka dapat disimpulkan tidak terdapat masalah heteroskedastisitas.

\section{e. Linieritas}

Tabel 8. Uji Linieritas

Ramsey RESET Test:

\begin{tabular}{llll}
\hline \hline F-statistic & 0.414658 & Probability & 0.527312 \\
Log likelihood ratio & 0.518145 & Probability & 0.471634 \\
\hline \hline
\end{tabular}

Test Equation:

Dependent Variable: LPDB

Method: Least Squares

Sample: 19902013

Included observations: 24

Sumber : Hasil olah data (2013) 


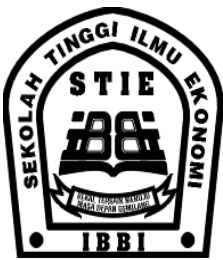

ISSN 1858-3199

JURNAL

MANAJEMEN BISNIS

STIE IBBI

Dari hasil output diatas pada tabel 8 dapat dilihat bahwa nilai $\mathrm{F}$ statistik sebesar 0,414658 lebih kecil dari nilai $\mathrm{F}$ tabel sebesar 3,10 sehingga dapat disimpulkan bahwa model regresi dikatakan linier.

\section{f. Uji t dan Uji F}

Tabel 9. Uji F

\begin{tabular}{lr} 
Mean dependent var & 14.25149 \\
S.D. dependent var & 0.276610 \\
Akaike info criterion & -0.539028 \\
Schwarz criterion & -0.342685 \\
F-statistic & 13.30882 \\
Prob(F-statistic) & 0.000053 \\
\hline \hline Sumber : Hasil olah data (2013)
\end{tabular}

Berdasarkan hasil uji F hasil rgresi secara simultan (bersama-sama) menunjukkan variabel bebas investasi asing langsung, nilai tukar, kredit perbankan dengan nilai $\mathrm{f}_{\text {hitung }}=13,30882$ dengan probabilitas 0,000053 berpengaruh positif dan signifikan terhadap pertumbuhan ekonomi.

Tabel 10. Uji t

\begin{tabular}{rr} 
t-Statistic & Prob. \\
\hline \hline 23.35567 & 0.0000 \\
2.993836 & 0.0072 \\
2.313778 & 0.0314 \\
-0.679457 & 0.5046 \\
\hline \hline
\end{tabular}

Sumber: Hasil olah data (2013)

Hasil penelitian ini menunjukkan bahwa secara parsial variabel kredit perbankan berpengaruh secara negatif dan tidak signifikan terhadap pertumbuhan ekonomi dengan nilai $t_{\text {hitung }}$ sebesar -0,679457 sedangkan variabel investasi asing langsung dan nilai tukar berpengaruh positif dan signifikan terhadap pertumbuhan ekonomi dengan nilai t hitung sebesar 23,35567 dan 2,993836

\section{PEMBAHASAN}

Dependent Variable: LPDB

Tabel 11

Method: Least Squares

Sample: 19902013

Included observations: 24

\begin{tabular}{cr}
\hline \hline Variable & Coefficient \\
C & 11.66901 \\
LFDI & 0.158826 \\
LNTR & 0.163826 \\
LCRD & -0.027297 \\
\hline \hline R-squared & 0.666258 \\
\hline \hline Sumber : Hasil olah data (2013)
\end{tabular}




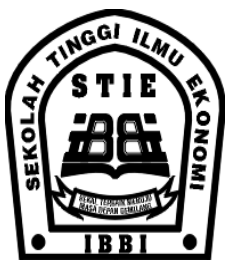

ISSN 1858-3199

JURNAL

MANAJEMEN BISNIS

STIE IBBI

Hasil estimasi dengan persamaan sebagai berikut :

$$
\mathrm{LPDB}=11,66901+0,158826 \mathrm{LFDI}+0,163826 \mathrm{LNTR}-0,027297 \mathrm{LCRD}+\mathrm{e}_{\mathrm{t}}
$$

Nilai konstanta $=11,66901$, artinya apabila variabel investasi asing langsung, nilai tukar dan kredit perbankan dianggap konstan atau tidak ada perubahan maka pertumbuhan ekonomi meningkat sebesar 11,6 persen.

Hasil penelitian ini menunjukkan variabel investasi asing langsung di Indonesia berpengaruh secara positif dan signifikan terhadap Produk Domestik Bruto sebesar 0,158826 artinya peningkatan investasi sebesar 1 juta US\$ akan mempengaruhi meningkatnya produk domestik bruto sebesar 15,88 persen.. Analisis yang dapat dikemukakan dalam penelitian ini bahwa masuknya modal asing juga dapat menggerakkan kegiatan ekonomi yang lesu karena kurangnya modal bagi pelaksanaan pembangunan ekonomi. Modal asing ini selain sebagai perpindahan modal juga dapat memberikan kontribusi positif melalui aliran industrialisasi dan modernisasi sehingga dapat meningkatkan hasil output / produksi barang dan jasa yang dapat memicu meningkatnya pertumbuhan ekonomi.

Selain itu, secara parsial variabel nilai tukar rupiah terhadap mata uang US dolar berpengaruh secara positif dan signifikan terhadap Produk Domestik Bruto sebesar 0,163826 artinya peningkatan nilai tukar mata uang rupiah terhadap US dolar akan mempengaruhi meningkatnya produk domestik bruto sebesar 16,38 persen. Analisis yang dapat dikemukakan dalam penelitian ini bahwa peningkatan mata uang rupiah terhadap mata uang asing akan mendorong kegiatan perekonomian secara makro karena mampu menurunkan biaya produksi sehingga produksi barang dan jasa meningkat, membuka peluang kerja bagi masyarakat dan sektor industri sehingga mampu meningkatkan pertumbuhan ekonomi.

Secara parsial variabel kredit perbankan berpengaruh secara negatif sebesar 0,027297 atau sebesar 2,73\% dan tidak signifikan terhadap Produk Domestik Bruto, artinya peningkatan kredit perbankan sebesar 1 persen akan mempengaruhi menurunnya produk domestik bruto sebesar 2,73 persen. Analisis yang dapat dikemukakan dalam penelitian ini bahwa peningkatan kredit perbankan kemungkinan belum tepat sasaran bagi sektor-sektor perekonomian yang mampu mendorong pertumbuhan ekonomi. Selain itu adanya masalah kredit macet juga menjadi masalah yang menimbulkan resiko bagi perbankan. Hasil penelitian ini, tidak sesuai dengan penelitian sebelumnya yang menyatakan bahwa penyaluran kredit mendorong pertumbuhan ekonomi suatu negara. Goldsmith (1969), Mc Kinon dan Shaw (1973) dalam Pratama (2010) menyatakan bahwa dana berlebih (surplus fund) yang disalurkan secara efisien bagi unit yang mengalami defisit akan meningkatkan kegiatan produksi. Selanjutnya kegiatan tersebut akan meningkatkan pertumbuhan ekonomi.

Angka koefisien determinasi ( $R$ square) sebesar 0.666258, menunjukkan bahwa secara keseluruhan variabel bebas (investasi asing langsung, nilai tukar, kredit perbankan) memberikan pengaruh sebesar 66,62 persen terhadap pertumbuhan ekonomi Indonesia selama kurun waktu $1990-2013$.

\section{KESIMPULAN DAN SARAN}

Kesimpulan

Dari hasil analisis data yang dilakukan dapat diperoleh kesimpulan bahwa :

1. Secara parsial investasi asing langsung berpengaruh positif dan signifikan terhadap pertumbuhan ekonomi tahun 1990 - 2013 
2. Secara parsial nilai tukar rupiah terhadap US\$ berpengaruh positif dan signifikan terhadap pertumbuhan ekonomi tahun 1997 - 2013

3. Secara parsial kredit perbankan berpengaruh negatif dan tidak signifikan terhadap pertumbuhan ekonomi tahun 1997 - 2013

4. Secara simultan variabel investasi asing langsung, nilai tukar dan kredit perbankan berpengaruh signifikan terhadap pertumbuhan ekonomi tahun 1997 - 2013

Saran

1. Pemerintah sebaiknya membuat kebijakan pembangunan infrastruktur yang lebih terarah ke wilayah - wilayah yang strategis yang dapat menggerakkan perekonomian lebih efektif. Selain itu menciptakan stabilitas keamanan nasional untuk menarik minat investor asing menanamkan modalnya di Indonesia sehingga berdampak positif terhadap pertumbuhan ekonomi Indonesia

2. Nilai tukar rupiah agar dipertahankan kestabilannya terhadap mata uang US\$ dengan cara meningkatkan kegiatan di sektor-sektor perekonomian secara makro baik dari sisi industri barang dan jasa serta menjaga kestabilan politik dan pemerintahan yang mendukung meningkatnya pertumbuhan ekonomi Indonesia

3. Sebaiknya bank sentral, bank umum dan bank perkreditan rakyat lebih berhati-hati dan lebih tepat sasaran dalam memberikan kredit perbankan sehingga mampu memberikan dampak yang menguntungkan bagi peningkatan pertumbuhan ekonomi Indonesia

\section{DAFTAR PUSTAKA}

Amri Amir. 2007. "Pengaruh inflasi dan pertumbuhan ekonomi terhadap pengangguran di Indonesia”. Jurnal Inflasi dan Pengangguran Vol. 1 no. 1,2007, Jambi.

Boediono, 1999. Ekonomi Moneter, Edisi 3, Yogyakarta : BPFE

Dornbusch, S. And R.Startz Fisher (1992). Macroeconomics. Seventh Edition. McGraw- Hill,New York.

Gujarati, Damodar, 2001. Ekonometrika Dasar, Cetakan Pertama. Alih Bahasa : Sumarno Zain. Jakarta Erlangga.

Judisseno, Rimsky K, 2002. Sistem Moneter Dan Perbankan Di Indonesia. Jakarta: PT. Gramedia Pustaka Utama.

Mudara, I Made Yogatama Pande. 2011. "Pengaruh Produk Domestik Bruto, Suku Bunga, Upah Pekerja dan Nilai Total Ekspor Terhadap Investasi Asing Langsung di Indonesia Tahun 19902009 ”. Skripsi. Semarang : Fakultas Ekonomi Universitas Diponegoro.

Pratama, Billy Arma, 2010, Analisis Faktor-faktor yang Mempengaruhi Penyaluran Kredit Perbankan (Studi pada Bank Umum Indonesia Periode 2005-2009). Tesis. Semarang : Program pascasarjana Magister Manajemen Universitas Diponegoro. 
Susilo. S, Triandaru. S. dan Santoso Totok Budi A.. 2006. Bank dan Lembaga Keuangan Lain, Edisi Kedua, Salemba Empat, Jakarta.

Tambunan, Tulus Tahi Hamonangan, 2006. Perekonomian Indonesia Sejak Orde Lama hingga Pasca Krisis. Jakarta: Pustaka Quantum.

Todaro Michael P., 2000, Economic Development, Seventh Edition, Ney York University, Addison Mesley.

Yoda Ditria, Jenni Vivian, Indra Widjaja. 2008. Pengaruh Tingkat Suku Bunga, Nilai Tukar Rupiah Dan Jumlah Ekspor Terhadap Tingkat Kredit Perbankan. Journal of Applied Finance and Accounting Vol. 1 No.1 November 2008:166-192. Jakarta : Universitas Bina Nusantara. 


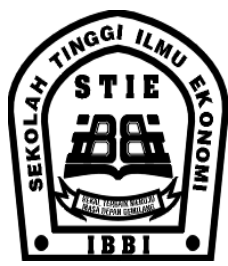

\title{
FORMULASI STRATEGI BERSAING GABUNGAN KELOMPOK TANI GOALPARA DALAM MENINGKATKAN DAYA SAING DI PASAR BEBAS
}

\author{
Alexander Barus \\ Dosen Tetap STIE IBBI
}

\begin{abstract}
Keberadaan agribisnis hortikultura Indonesia dengan konteks persaingan pasar bebas merupakan suatu tantangan besar. Para pelaku dituntut untuk dapat beroperasi secara efisien dan dapat menghasilkan suatu produk yang sesuai dengan kebutuhan dan keinginan pasar. Faktor lain yang mendukung untuk pengembangan agribisnis hortikultura di Indonesia adalah agroklimat yang sangat sesuai untuk pertumbuhan dan perkembangan sayur mayor dengan baik.Pada pihak lain pertumbuhan volume impor Indonesia terhadap beberapa komoditi sayur-mayur mengalami kenaikan tinggi. Lebih jauh asosiasi perhimpunan hortikultura Indonesia memproyeksikan perkiraan permintaan produk hortikultura Indonesia pada tahun-tahun kedepan mengalami pertumbuhan positif.

Perumusan Masalah Bagaimana lingkungan factor Internal Gapoktan mempengaruhi kinerja Gapoktan kedepan? Bagaimana lingkungan eksternal Gapoktan mempengaruhi kinerja Gapoktan kedepan? Bagaimana Gapoktan merumuskan strategi bersaing dalam rangka meningkatkan daya saing tinggi ditengah-tengah persaingan di bidang agribisnis yang semakin tinggi?

Dalam penelitian ini digunakan metode penelitian deskriptif dalam bentuk studi kasus. Pemilihan metode ini bertujuan untuk memperoleh gambaran yang luas dan lengkap mengenai subjek yang diteliti. Pada penelitian ini menggunakan teknik pengolahan dan analisa data dengan menggunakan analisis Matriks Internal dan Eksternal, Analisis Matrik SWOT,

Matriks SWOT memberikan beberpa alternative startegi yang dapat digunakan Gapoktan dalam emnjalankan usaha kedepan. Startegi-strategi yang berhasil dirumuskan diatas berdasar analisis terhadap factor internal dan luar Gapoktan. Dari hasil analisis IFE dan EFE dihasilkan: Matrik internal factor menunjukkan ada 4 parameter kekuatan Gapoktan yakni: keterampilan yang dimiliki, agroklimat yang baik, citra positif dan kepsstian pasar yang relative. Sedangkan Kelemahan Gapoktan: variability kualitas masih relative tinggi bila diukur dalam rangka pemenuhan standard kualitas konsumen; dan aspek manajemen yang belum solid. Peluang Gapoktan: potensi besar untuk melayani pasar dalam negeri dan luar negeri. Ancaman gapoktan: : nilai tukar; inflasi, yang mengakibat flutuasi harga. Dari analisa SWOT dihasilkan Matrik strategi yangterdiri dari: Strategi Kekuataan - Kelemahan; Strategi Kekuatan - Ancaman; Strategi Kelemahan - Peluang; Startegi Kelemahan - Ancaman

Gapoktan merupakan kelompok gabungan tani yang sudah berwawasan agribisnis di akwasan Jawa Barat. Kelompok ini sudah diarakahkan kepada pertanian yang modern dengan orientasi kepada pilihan konsumen. Beberapa hal yang perlu diperbaiki dan tingkatkan Gapoktan kedepan agar produktifitas emakin lebih baik dan dapat melayani kebutuhan dan keinginan konsumen agribisnis di Indonesia.
\end{abstract}

Keynotes: Gapoktan Goalpara, Matrik IFE dan EFE, Matrik SWOT, Strtegi Bersaing, 


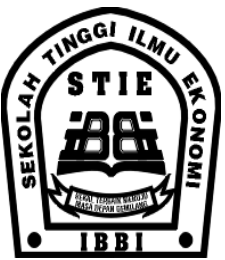

ISSN 1858-3199

JURNAL

MANAJEMEN BISNIS

STIE IBBI

\section{I.1 Latar Belakang}

Memasuki pasar bebas muncul beberapa perubahan yang mendasar tata hubungan dagang diantara Negara-negara seperti, mudahnya perpindahan arus barang/jasa, factor produksi, tingginya lalulintas tenaga kerja dari satu Negara ke Negara lain lain. Kondisi ini membuat suatu Negara harus bekerja secara efisien dan efektif, agar perusahaan dapat bersaing sehingga produk yang dihasilkan mempunyai daya saing dipasar global.

Globalisasi ekonomi dunia mengakibatkan perubahan tatalaku, institusi dan kerjasama perdagangan antar Negara. Globalisasi itu sendiri merupakan suatu revolusi dalam pasar karena pasar menjadi semakin terbuka, seolah tanpa ada batas geografi. Berbagai kesepakatan yang mengatur perdagangan internasional yang adil terus diupayakan dan di bahas di forum-forum internasionalseperti World Trade International (WTO), Asean Free Trade Area (AFTA) atau Asia Pasific Economic Coorporation (APEC).

Ciri khas perubahan-perubahan lingkungan strategic diatas adalah keterbukaan menuju ekonomi pasar. Persetujuan World Trade Organization misalnya mensyaratkan bahwa setiap anggota penandatangan perjanjian harus lebih membuka pasarnya masing-msaing melalui pengurangan hambatan perdagangan, dan lebih membuka pintu bagi para investor asing untuk beroperasi dalam lingkungan domestic. Karena keterbukaan pasar berarti menyatunya pasar dunia dengan pasar domestic. Dengan begitu untuk dapat memenangkan persiangan dalam negeri pun, suatu produk harus dapat mempunyai daya sing yang lebih tinggi dari produk impor Negara lain. (Nuhung, 2000).

Keberadaan agribisnis hortikultura Indonesia dengan konteks persaingan pasar bebas merupakan suatu tantangan besar. Para pelaku dituntut untuk dapat beroperasi secara efisien dan dapat menghasilkan suatu produk yang sesuai dengan kebutuhan dan keinginan pasar. Faktor lain yang mendukung untuk pengembangan agribisnis hortikultura di Indonesia adalah agroklimat yang sangat sesuai untuk pertumbuhan dan perkembangan sayur mayor dengan baik.

Rata-rata pertumbuhan produksi sayur-mayur dari tahun 1992 - 1997 di Indonesia mengalami pertumbuhan yang tinggi. Rata-rata pertumbuhan produksi sayur-mayur per tanaman diatas pertumbuhan 5 persen. Pertumbuhan produksi tinggi tersebut merupakan gambaran kebutuhan masyarakat terhadap sayur-mayur tinggi. Bila dilhat dari pertumbuhan volume ekspor sayur-mayur Indonesia, dari tahun 1994 hingga tahun 1998 mengalami pertumbuhan negative.

Pada pihak lain pertumbuhan volume impor Indonesia terhadap beberapa komoditi sayurmayur mengalami kenaikan tinggi. Lebih jauh asosiasi perhimpunan hortikultura Indonesia memproyeksikan perkiraan permintaan produk hortikultura Indonesia pada tahun-tahun kedepan mengalami pertumbuhan positif.

\section{I.2 Perumusan Masalah}

1. Bagaimana lingkungan factor Internal Gapoktan mempengaruhi kinerja Gapoktan kedepan?

2. Bagaimana lingkungan eksternal Gapoktan mempengaruhi kinerja Gapoktan kedepan?

3. Bagaimana Gapoktan merumuskan strategi bersaing dalam rangka meningkatkan daya saing tinggi ditengah-tengah persaingan di bidang agribisnis yang semakin tinggi?

\section{I.3 Tujuan Penelitian}

Pelaksanaan penelitian ini diharapkan dapat memenuhi minimal 3 tujuan penelitian, yakni:

1. Mengkaji lingkungan internal Gapoktan secara menyeluruh meliputi kekuatan-kekuatan dan kelemahan-kelemahannya. 


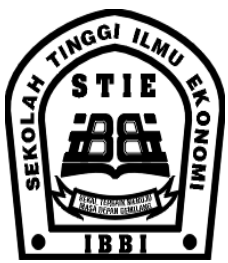

ISSN 1858-3199

JURNAL

MANAJEMEN BISNIS

STIE IBBI

2. Mengkaji lingkungan eksternal perusahaan berupa factor peluang yang dapat dimanfaatkan gapoktan serta Ancaman yang harus dihindari oleh perusahaan

3. Merumuskan alternative strategi bersaing bagi Gapoktan ke depan.

\section{I.4 Ruang Lingkup dan Batasan Masalah}

Ruang lingkup penelitian ini difokuskan untuk mengkaji kondisi internal dan eksternal gapoktan serta merumuskan strategi perusahaan kedepan.

\section{Tinjauan Pustaka}

II.1 Manajemen Strategi

Manajemen Strategi didefinisikan sebagai seni dan ilmu dalam merusmuskan, mengimplementasikan, dan evaluasi keputusan-keputusan lintas fungsional yang memampukan suatu organisasi mencapai tujuannya. (David, 1999)

Manajemen Strategi didefiniskan sebagai suatu kumpulan keptuusan dan tindakan yang member hasil dalam formulasi dan implementasi rencana yang didesain untuk mencapai tujuan perusahaan (pearce dan Robinson, 1997).

\section{II.2 Strategi Bisnis}

Menurut Minzberg dan Quinn (1996) strategi adalah pola dan rencana yang mengintegrasikan tujuan utama perusahaan, kebijakan-kebijakan dan urutan tindakan yang menyeluruh terpadu

Jauch dan Glueck (1994), menyatakan strategi adalah rencana yang disatukan, menyeluruh dan terpadu yang mengaitkan keunggulan strategi perusaaan dengan tantangan lingkungan dan yang dirancang untuk memastikan bahwa tujuan utama perusahaan dapat dicapai melalui pelaksanaan yang tepat oleh perusahaan.

\section{II.3 Manfaat Manajemen Strategi}

Manajemen strategi akan memudahkan bagi organisasi untuk mencapai tujuan yang ditetapkan, memudahkan perusahaan untuk lebih proaktif melihat masa depan perusahaannya, memiliki inisiatif untuk mengadakan perusahaan-perubahan kegiatan bilamana diperlukan dengan mempertimbangkan perusahaan eksternal. Dengan kata lain manajemen strategi membantu perusahaan untuk menentukan keberadaaan bisnis pada masa depan.

David (1997) menggaris bawahi ada 2 manfaat dari manajemen strategi, yakni:

1. Manfaat financial.

Berdasarkan penelitian mengindikasikan bahwa perusahaan yang menggunakan konsep manajmeen strategi memiliki tingkat kesuksesan dan profitabilitas yang lebih bila dibandingkan dengan perusahaan yang tidak menggunakan konsep tersebut. Berdasarkan suatu studi, lebih dari $80 \%$ perbaikan profitabilitas perusahaan dicapai melalui perubahanperubahan yang menyangkut strategi.

2. Manfaat Non-finansial

Disamping membantu perusahaan dalam menghindari kegagalan keuangan, strategi manajmen juga membantu meningkatkan kesadaran atas ancaman lingkungan luar, meningkatkan pemahaman strategi bersaing, meningkatkan produktifitas karyawan, menurunkan sikap enggan berubah dari karyawan, serta memberkan pemahaman akan hubungan antara performance dengan system reward yang diberlakukan.

\section{II.4 Proses Manajemen Strategis}

Menurut David (1999), proses manajemen strategi terdiri atas 3 tahap: 
1. Formulasi Strategi

Formulasi strategi adaah proses merancang dan menyeleksi strategi agar misi dana tujuan perusahaan dapat tercapai.

2. Implementasi Strategi

Berdasarkan hasil formulasi strategi, diambil tindkaan untuk mencapai tujuan

3. Evaluasi Strategi

Pemantauan dan evaluasi terhadap aplikasi strategi yang telah dirumuskan, evaluasi tujuan ini bertujuan untuk memantau dan menganalisis apakah tujuan yang telah ditetapkan dapat tercapai melalui strategi yang dilaksanakan perusahaan

\section{II.5 Analisa Lingkungan Bisnis}

\section{II.5.1 Lingkungan Internal}

Keberhasilan suatu perusahaan sangat tergantung atas pengenalan diri perusahaan itu sendiri. Perusahaan harus dapat mengidentifikasi bagian-bagian kekuatan yang dimiliki, bagian kelemahan-kelemahan yang dimiliki. dengan adanya analisis internal tersebut akan memberikan suatu informasi pijakan bagi perusahaan tentang keberadaaan bisnisnya pada saat ini, serta kemungkinan-kemungkinan pengembangan perushaaan lebih jauh kedepan.

\section{II.5.2 LIngkunga Eksternal}

Kehidupan suatu lembaga binsis atau non-bisnis dalam menjalankan perannya sangat dipengaruhi bukan saja dipengaruhi oleh kondisi internal perusahaan saja. Faktor-faktor diluar variable internal juga memiliki peranan yang sangat vital, terlebih-lebih ditengah-tengah perubahanperubahan yang sangat dinamis yang dodorong oleh perkembnagan ilmu pengetahuan dan teknologi.

\section{a. LIngkungan Makro}

Lingkungan Makro terdiri dari komponen-komponen: ekonomi, social-budaya, politik, teknologi, hukum.

b. Lingkungan Mikro/Industri

Pemahaman karakteristik industry sangat vital dalam upaya merumuskan strategi bersaing, yakni cara perusahaan menyesuaikan diri serta merumuskan kesesuaian stratgei dengan lingkungan yang selalu berubah (Porter, 1997).

Lima kekuatan yang mempengaruhui persiangan dalam suatu industry:

1. Penghalang masuk

Beberapa factor yang berpengaruh terhadap penghalang masuk, yakni: skala ekonomi, diferensiasi produksi, persyaratan modal modal, akses distribusi, kebijakan pemerintah, keunggulan biaya.

2. Penentu kekuatan pemasok

Beberapa factor yang menentukan kekuatan pemasok, antara lain adalah: diferensiasi masukan, biaya peralihan pemasok dan perusahaan, adanya masukan pengganti, konsentrasi pemasok, pentingnya volumebagi pemasok, biaya yang berhubungan dengan pembelian total dalam dalam industry, dampak masukan pada biaya atau diferensiasi, ancaman integrasi kedepan yang berhubungan dengan ancaman integrasi kebelakang oleh perusahaan dalam industry.

\section{Penentu ancaman produk pengganti}

Beberapa factor yang mempengaruhi antara lain: kinerja harga relative dari pengganti, biaya peralihan, kecenderungan pembeli terhadap produk pengganti. 


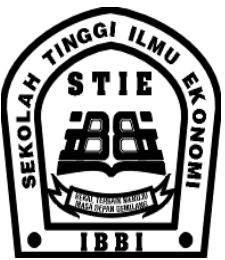

ISSN 1858-3199

JURNAL

MANAJEMEN BISNIS

STIE IBBI

\section{Penentu persaingan}

Beberapa fakto yang mempengaruhi kekuatan persaingan antara lain adalah: perkembangan industry, biaya tetap (atau penyimpanan)/ nilai tambah, kelebihan kapasitas intermitten, diferensiasi produk, identitas merek, biaya peralihan, konsentrasi dan keseimbnagan, keragaman pesaing.

5. Penentu kekuatan pembeli

Beberapa factor yang mempengaruhi: konsentrasi pembeli versus konsentrasi perusahaan, volume pembeli, biaya peralihan pembeli yang berhubung dengan biaya peralihan perusahaan, informasi pemebli, kemampuan untuk integrasi ke belakang, produk pengganti.

\section{Metode Penelitian}

\section{III.1 Metode Penelitian}

Dalam penelitian ini digunakan metode penelitian deskriptif dalam bentuk studi kasus. Pemilihan metode ini bertujuan untuk memperoleh gambaran yang luas dan lengkap mengenai subjek yang diteliti.

\section{III.2 Teknik Pengolahan dan Analisa Data}

\section{III.2.1 Analisis Matriks Internal dan Eksternal}

Analisis factor lingkungan internal dimaksudkan untuk memahami kekuatan dan kelemahan yang dimiliki perushaaan. Untuk memudahkan analisis ini dilakukan satu persatu untuk setiap fungsi dalam perusahaan, seperti fungsi pemasaran, keuangan, litbang, produksi dan lainnya. Daftar kekuatan dan kelemahan yang diperoleh dari hasil analisis fungsional harus dievaluasi dengan menggunakan matriks lingkungan internal - internal factor evaluation (IFE). Selanjutnya analisis lingkungan eksternal - External Factor Evaluation (EFE) bertujuan untuk memahami factor peluang bagi perusahaan dan mengantisipasi atau menghindari adaanya ancaman dari factor luar terhadap kemungkinan terhambatnya kelancaran operasi perusahaan.

\section{2.2 Tahap Analisis Data}

\section{a. Analisis Matrik SWOT}

An alisis situasi perusahaan merupakan suatu cara untuk mendapatkan gambaran lingkungan stratgeis perusahaan dan kegiatannya yang ditinjau dari aspek internal dan eksternal yang dimiliki perusahaan. Analisis situasi perusahaan akan menghasilkan identifiikasi kemampuan khusus yang dimiliki perusahaan

Table 3. Matriks SWOT

\begin{tabular}{|c|c|c|}
\hline \multirow{2}{*}{$\begin{array}{ll}\text { Faktor Eksternal } & \text { Faktor Internal }\end{array}$} & Kekuatan (S) & Kelemahan (W) \\
\hline & Strategi SO & Strategi WO \\
\hline Peluang $(\mathrm{O})$ & $\begin{array}{lrr}\text { Susun strategi } & \text { dengan } \\
\text { menggunakan kekuatan } & \text { untuk } \\
\text { meraih peluang } & & \\
\end{array}$ & $\begin{array}{l}\text { Susun strategi untuk memperoleh } \\
\text { keuntungan dari peluang yang ada } \\
\text { dalam mengatasi kelemahan }\end{array}$ \\
\hline \multirow[t]{2}{*}{ Ancaman (T) } & Strategi ST & Strategi WT \\
\hline & $\begin{array}{l}\text { Susun stratgei dengan } \\
\text { memanfaatkan kekuatan yang ada } \\
\text { untuk menghindari ancaman }\end{array}$ & $\begin{array}{lcc}\text { Susun strategi dengan cara } \\
\text { meminimumkan kelemahan } & \text { dan } \\
\text { menghindari ancaman } & \\
\end{array}$ \\
\hline
\end{tabular}

Sumber: PearcE dan Robinson, 1991 


\section{b. Analisis matrik Internal Eksternal (IE)}

Matrik Internal Eksternal ini merupakan pengembangan dari model General Electric (GE). Parameter yang digunakan meilputi parameter internal perusahaan dan eksternal yang dihadapi.

\section{III.3 Kerangka Konseptual}

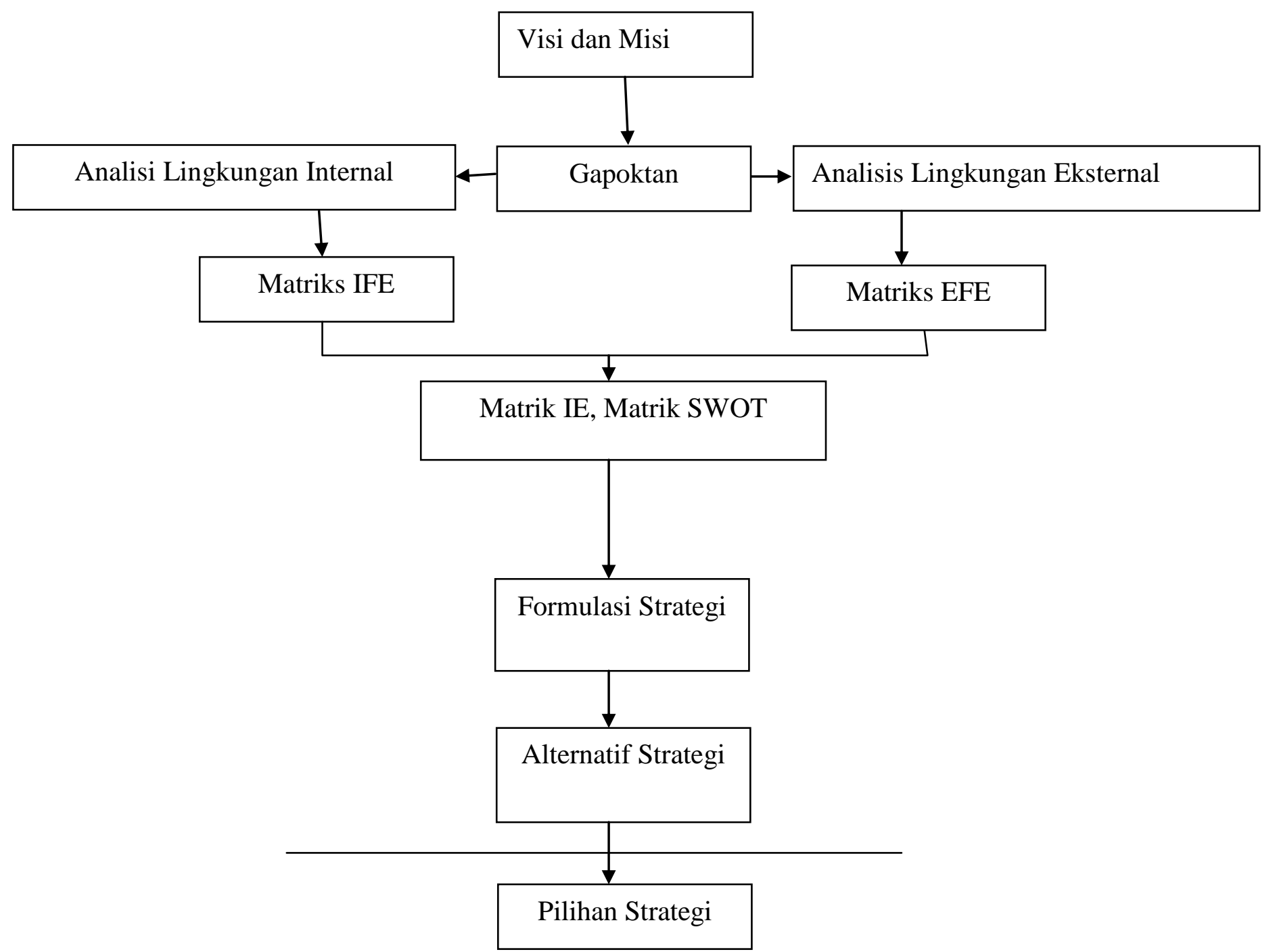

Gambar 3. Kerangka Konseptual

Dalam rangka merumuskan strategi suatu perusahaan ataupun lembaga lain, langkah awal yang perlu dilakukan adalah menganalisis visi dan misi perusahaan. Kedua hal tersebut adalah 


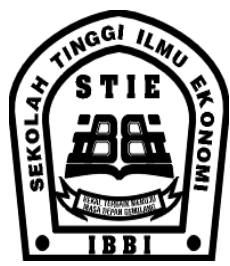

ISSN 1858-3199

JURNAL

MANAJEMEN BISNIS

STIE IBBI

merupakan suatu pernyataan diri perusahaan atau lembaga, mengenai keberadaannya serta cita-cita yang hendak dicapai perusahaan. Selanjutnya yang dilakukan analisis factor internal perusahaan mengenai peta kekuatan dan kelemahannya. Langkah berikutnya yang saling menyatu adalah menganalisis factor lingkungan luar perusahaan atau lembaga dimana perusahanan beroperasi. Lingkungan luar meliputi analisis factor ekonomi, politik, social dan teknologi serta analisis lingkungan industry dimana perusahaan termasuk didalamnya. Kedua analisis tersebut merupakan langkah penting dalam rangka mengumpulkan informasi yang selenghkap dan seakurat mungkin. Informasi yang terkumpul kemudian diolah melalui penggunaan matrik IFE dan EFE. Selanjutnya menyusun matrik IE (internal dan eksternal) yang dapat memberikan gambaran strategi pada tingkat korporat yang lebih spesifik. Selain penggunaan matrik IE, digunakanjuga matrik SWOT yang merupakan suatu alat analisis yang dapat memberikan detail mengenai pemanfaatan peluang dan menghindari ancamandengan memanfaatkan kekuatan dan pengelolaan kelemahan perusahaan. Matrik SWOT memberikan berbagai alternative startegi bagi perusahaan dalam menyusun stratgei yang disesuaikan dengan kondisi internal dan eksternal perusahaan.

Dari hasil analisis yang dilakukan diatas maka akan dirumuskan strategi bagi eprusahaan kedepan dalam rangka menghadapi persaingan yang makin hari makin ketat. Langkah selanjutnya adalah melakukan alternative pilihan strategi yang dianggap paling tepat bagi perusahaan. Yang kemudian akan diikuti oleh tahap implementasi oleh perusahaan. Langkah terakhir adalah mengadakan evaluasi terhadap hasil penerapan startegi bagi kinerja perusahaan secara keseluruhan. Pada tahap ini implementasi dan evaluasi merupakan wewenang dari perusahaan, diluar tanggungjawab peneliti.

\section{Gambaran Umum Gapoktan Goalpara \\ IV.1 Sejarah Gabungan Kelompok Tani Goalpara}

Pada bulan November tahun 1997, sebanyak 19 kelompok tani di jalur jalan Goalpara Kecamatan Sukaraja sepakat membentuk Gabungan Kelompok Tani (GAPOKTAN).

Wilayah kerja Gapoktan berada pada daerah pegunungan dengan ketinggian tempat antara 9001300 meter diatas permukaan laut, dengan suhu rata-rata 18-30 derajat Celsius, curah hujan berkisar antara $2.000-4.000 \mathrm{~mm}$ pertahun serta kelembaban relative (RH) $85 \%$. Kondisi tanah didominasi oleh tanah latasol merah coklat dengan topografi landai, dengan iklim yang memiliki 3-4 bulan kering.

Gapoktan berdiri berdasarkan

V. Hasil dan Pembahasan

V.1 Analisis Internal Perusahaan

a. Dalam menjalankan Gapoktan para anggota dan pengurus menetapkan suatu cita0cita yang emnjadi araah pembangunan dan pengembangan Gapktan Goalpara. Visi yang ditetapkan yang menjadi arah usaha Gapktan Goalpara kedepan adalah " merubah wajah pertanian yang bercorak tradisional menjadi pertanian yang terpola dan tertata dalam rangka menuju pertanian modern,yang pada akhirnya dapat memiliki kekuatan tawar menawar dipasar domestikmaupun internasional, yang pada giliran dapat meningkatkan kesejahteraan petani”. Visi ini merupakan merupakan pertanyaan atas visi: "what do we want to become?" Misi yang diemban Gabungan kelompok Tani Goalpara adalah " menjadikan jalur Goalpara menjadi kawasan agribisnis yang handal dan kuat:.

b. Struktur Organisasi Gapktan Goalpara

Gapoktan merupakan sekumpulan kelompok tani diantaranya, kelompok tani Goalpara, kelompok tani Cisarua, Limbnagan, Kuta, Cipaku, dan kelompok tani Harsfarm. Jadi penyusunan Gapoktan 


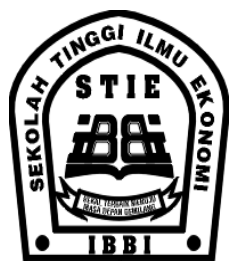

ISSN 1858-3199

JURNAL

MANAJEMEN BISNIS

STIE IBBI

merupakan kelompok-kelompokm tani, dimana kelompok tani itu sendiri terdiri dari para anggota petani.Setiap kelompok tani dikordinir oleh seorang yang diangkat sebagai coordinator kelompok. Fungsi koordidnator adalah penghubung antara kepentingan Gapoktan dengan para anggota petani.

Struktur organisasi Gapoktan terdiri dari seorang Ketua, seorang sekretaris serta dibantu oleh lima didvisi, terdiri dari divisi produksi, divisi pemasaran dan pengolahan hasil, divisi keuangan, divisi riset dan pengembangan serta koperasi. Disamping kelima divisi diatas struktur organisasi Gapoktan juga memiliki seorang staff ahli yang merupakan staff penasihat dalam pengembangan Gaapoktan Goalpara.

\section{c. Produksi}

Departemen produksi membuat rencana produksi dan bertanggungjawab terhadap pengaturan pola tanam dan jenis tanam. Departemen ini mengkoordinasikan seluruh lahan petani untuk menjalankan program yang telah ditetapkan. Komoditi unggulan gapoktan Goalpara adalah tomat arthaloka, cab, kubis, swai putih dan kentang.

Dari aspek produk ada beberapa masalah yang ditemui dari hasil wawancara maupun pengamatan dilapangan. Pertama adalah permasalahan pada jajaran kepengurusan/anggota petani. Permasalahan yang terjadi pada departemen produksi bukan merupakan sebatas permasalahan teknologi produksi atau penanganan psaca panen atau lainnya melainkan masih kurang menyatunya para pengurus dan anggota dalam Gapktan untuk komitmen terhadap visi dan misi yang telah ditetapkan.

Permasalahan kedua adalah masalah standard kualitas komoditi yang belum merata.

\section{d. Pemasaran dan Pengolahan}

Usaha pemasaran produk pada dasarnya dapat dilihat dari 4 komponen atau unsure pemasaran, yakni: produk, harga, promosi dan tempat/saluran distribusi.

1. Produk/komoditi: komoditi yang diproduksi dan dipasarkan gapoktan merupakan sayur mayor komersial, seperti: Kubis, Buncis, Sawi Putih, Tomat, Kentang, Wortel, Cabai Keriting, Cabai Besar.

2. Harga: Ada beberapa metode yang diterapkan Gapoktan dalam menetapkan harga komoditi, yakni berdasarkan kesepakatan didepan (harga harga per periode - musim tanaman, bulan, atau bahkan tahunan).

3. Promosi: Ada beberapa cara yang dilakukan gapoktan dalam mempromosikan komoditinya., seperti keikutsertaan pada pengurus Gapoktan sebagai pembicara dalam seminar-seminar pengembangan agribisnis, promosi melalui Pembina Penyuluh Lapangan (PPL) dinas pertanian, kunjungan ke sentra produksi agribisnis hortikultura lain atau dikunjungi oleh para tamu luar, penyebaran leaflet, promosi dari mulut ke mulut.

4. Tempat: pepmasaran atau pendistribusi komoditi yang dihasilkan anggota gapoktan langsung dari tingkat produsen ke konsumen.

Disamping permaslahan kualitas, sebagian para anggota petani masih memasarkan hasil rpoduksinya tanpa melalui Gapktan Goalpara. Ada beberapa hal yang harus diperbaiki oleh anggota Gapoktan dalam memasarkan produk hasil anggota petani yakni, kesiapan Gapoktandalam mendidik para anggotapetani untuk dapat menghasilkan produk sesuai dengan kualitas yang dinginkan pasar. Adanya kebebasananggota petani untuk memasarkansendiri komoditinya dapat ditunjukkan melalui minimnya data-data penjualan Gapoktan perjenis tanaman yang diproduksi anggota petani yang terkumpul di bidang administrasi gapoktan. Sentralisasi pemasaran kedepan perlu lebih ditekankan, hal implikasi terhadap kesiapan dan profesisonalitas bagian pemasaran Gapoktan 


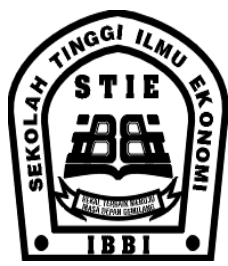

ISSN 1858-3199

JURNAL

MANAJEMEN BISNIS

STIE IBBI

\section{d. Riset dan Pengembangan}

Riset dan Pengembangan merupakan kunci kritis keberhasilan suatu organisasi dalam era pasar bebas. Peran riset dan pengembangan pada Gapoktan telah berjalan dengan cukup baik, dan memiliki kontribusi terhadap kinerja Gapoktan. Riset dan Pengembangan yang dijalan bukan dengan teknologi mesin dan laboratarium dengan segala peralatan canggihnya didalamnya. Riset dan Pengembangan yang dilaksanakan oleh Gapoktan masih sebatas uji coba dilahan terbuka, baik pembibitan ataupun pola budidaya tertentu sampai mendapatkan produktifitas dan hasil produk dengan kualitas yang lebih baik dari waktu ke waktu.

\section{e. Keadaan Wilayah Gapoktan}

Peluang Gapoktan Goalpara sebagai sentra produsen komoditas sayur mayor untuk tingkatnasional kedepan didukung dengan luasan lahan tani kolektif kurang lebih 1575 ha yang dapat dikembangkan bagi pembentukan kawasan sentra produsen agribisnis sayur mayor. Pengembangan integrated farming kedepan merupakan sasaran terhadap Gapoktan Goalpara Sukabumi. Realisasi pemanfaatn lahan kolektif masih pada kisaran 23,30 persen. Areal lahan luas merupakan salah satu kekautan Gapoktan dalam memasuki pasar bebas kedepan.

\section{V.2 Analisis Eksternal Perusahaan}

\section{V.2.1 Analisis Lingkungan Makro}

\section{a. Faktor Ekonomi}

Secara keseluruhan laju pertumbuhan ekonomi Indonesia pada tahun 1999 diperkirakan menjadi positif. Ini menunjukkan salah satu tanda pemulihan perekonomian Indonesia. Berdasarkan perhitungan PDB atas dasar harga konstan 1993, laju pertumbuhan ekonomi Indonesia pada tahun 1999 adalah sekitar 0,23 persen (BPS, 1999). Ini berarti bahwa Indonesia telah mulai bergerak dari kelumpuhan kegiatan ekonomi.

Beberapa indicator perekonomian yang dapat menunjukkan kondisi ekonomi serta tingkat kesejahteraan suatu bangsa atau negra, seperti: pendapatan nasional per kapita, produk domestic bruto, tingkat inflasi, nilai tukar, tingkat suku bunga dan lain sebagainya akan dibhas ekilas dampaknya terhadap pembangunan ekonomi terutama dalam sector agribisnis di Indonesia.

- Pendapatan nasional per kapita Pendapatan perkapita merupakan salah satu indkator yang digunakan untuk mengukur tingkat kesejahteraan penduduk. Perkembangan pendapatan nasional per kapita Indonesia mengalami penurunan secara signifikan sejak terjadinya krisis ekonomi pertengahan tahun 1997. Tahhun 1996 pendatan nasional perkapita Indonesia sebesar Rp. 1.851.811,40 yang mengalami kenaikan selama tahun 1997 menjadi Rp. 1.851.611,60. Pednapatan nasional perkapita Rp. 1.615.265,20 (1998), Rp. 1.593.628,00 (1999).

- Produk Domestik Bruto Perkembangan PDB Indonesia Rp 376.051,60 miliar (1998) atas dasar harga konstan mengalami penuruanan dari $\mathrm{Rp} 413.797,90$ miliar (1996), dan Rp. 433.245,90 miliar (1997) tetapi tahun 1999 PDB Indonesia mengalami kenaikan menjadi Rp. 376.902,50 miliar. Perkembnagan yang menurun sejak tahun 1998 merupakan suatu akumulasi dari segala permaslahan eknomipolitik yang dialami bangsa Indonesia. Kondisi tersebut sangat mematikan roda perekonomian hal ini ditandai dengan pertumbuhan ekonomi tahun 1998 negatif 13,20 persen. Pertumbuhan ini menggambarkan kondisi ekonomi yang lumpuh dimana banyak perusahaan menurunkan kemampuan produksi dan sebagian besar menutup operasi perusahaan. 


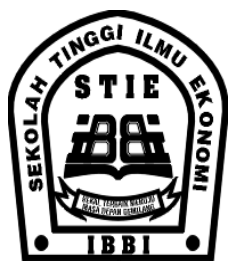

ISSN 1858-3199

JURNAL

MANAJEMEN BISNIS

STIE IBBI

Salah satu sector yang ikut mendorong pertumbuhan eknomi adalah sector agribisnis yang selama krisis mengalami pertumbuhan positif. Indikator inilah yang kembali menempatkan sector agribisnis adalah sector yang dapat ditempatkan sebagai dasar pembangunan ekonomiIndonesia kedepan dengan mempertimbangkan bahwa Negara Indonesia adalah Negara agraris dengan kesuburan tanah dan iklim yang tepat untuk pengembangan agribisnis secara professional.

Tabel 14. Tingkat Pertumbuhan PDB (\%) Indonesia

\begin{tabular}{|c|c|c|c|c|}
\hline Tahun & 1996 & 1997 & 1998 & 1999 \\
\hline Persen & 7,82 & 4,70 & $(13,20)$ & 0,23 \\
\hline
\end{tabular}

- Nilai Tukar

Kemajuan suatu Negara dapat dilihat dari kekuatan nilai mata uang suatu Negara yang diperbandingkan dengan nilai mata uang Negara lain. Nilai mata uang menduduki posisi yang sangat sentral dalam pembnagunan ekonomi terutama untuk Negara-negara yang sedang membangun. Nilai tukar Rupiah terhadap Dollar AS mengalami depresiasi secara drastic sejak krisis ekonomi melanda Indonesia dari nilai tukar Rp. 2.200,0 (1997) menjadi Rp. 8.760,00 per Dollar AS (2000, triwulan II). Kodnisi tersebut menghambat pembnagunan eokonomi, dimana Indonesia masih sangat membutuhkan modal dalam bentuk mesin-mesin pabrik.

- Tingkat Inflasi \& Suku Bunga

Tingkat inflasi yang tinggi merupakan beban yang berat bagi masyarakat Indonesia. Tingkat inflasi pada tahun 1997 yajni sebesar 77,63 persen, dimana daya beli masyarakat Indonesia pada saat itu sangat rendah. Tingkat kesejahteraaan turun. Inflasi yang tinggi mematikan sector ekonomi.

\section{- Ekspor-Impor}

Kecenderunga impor sayur mayor Indonesia meningkat dan disertai dengan aemkain menurunnya kecenderungan ekspor sayur mayor memberikan suatu gambaran tingginya permintaan sayur mayor oleh konsumen dalam negeri. Pada table 17 bisa ditarik kesimpulan bahwa Negara Indonesia kecendeutngan dari tahun ke tahun mengalami impor yang besar. Artinya kemungkinan adalah peluang untuk memenuhi permintaan sayur mayor dalam negeri peluangnya sangat besar. Pelaku ekonomi harus memanfaatkan kondisi ini, dengan memproduksi komidit dengan kualitas tinggi dan harga yang efisien. Sehingga kedepannya, bangsa kita dapat menjadi tuan rumah untuk memenuhi kebutuhan sayur mayur masyarakatnya.

\section{b. Politik, Hukumd dan Pemerintah}

Gejolak politik yang terus menerus menerpa Indonesia serta penegakan hukum yang belum serius merupakan factor yang mempengaruhi perkembangan pada sector ekonomi. Investor dalam negeri maupun luar negeri akan merasa sangat riskan untuk menanamkan modalnya di Indonesia baik itu dalam bentuk pendirian perusahaan, kerjasama/patungan maupun pembelian saham-saham perusahaan Indonesia. 


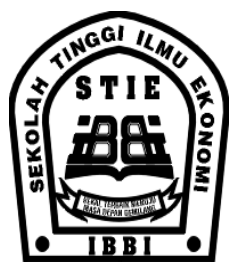

ISSN 1858-3199

JURNAL

MANAJEMEN BISNIS

STIE IBBI

Sedangkan dari sisi penegakan hukum, pemerintah sekarang belum menegakkan supremasi hukum sesuai dengan harapan banyak masyarakat. Keadilan masih diperjual belikan oleh kalangan bermodal. Berbagai Undang-Undang, peraturan pemerintah dikeluarkan untuk pengembangan usaha kecil, menengah dan koperasi. Beberapa diantaranya adalah: UndangUndang Nomor 25 tahun 1992, tentang perkoperasian; UU Nomor 9 tahun 1995 tentang usaha kecil dimana pemerintah, dunia usaha dan masyrakat melakukan pembinaan dan pengembangan lembaga pemasaran dan jaringan distribusi, lembaga pengembangan bidang desain dan teknologi; Peraturan Pemerintah Nomor 44 Tahun 1997, tentang kemitraan; Peraturan Pemerintah RI Nomor 32 tahun 1998 tentang pembinaan dan pengembangan usaha kecil. Kebijakan pendukung permodalan bagi pengembang koperasi, usaha kecil dan menengah baik investasi maupun modal.

\section{c. Teknologi}

Kemajuan teknologi merupakan penyumbang besar dalam proses pergeseran struktur perekonomian di hampir semua Negara. Mulai dari struktur ekonomi pertanian mengarah keapda ekonomi manufaktur hingga terciptanya struktur ekonomi jasa. Dalam bidang pertanian perkembangan teknologi dapat diidentifikasi dengan mengelompokkannya berdasar subsistem agribisnis (Saragih, 1998), yakni subsector agribisnis hulu (upstream agribusiness), subsector primer (on-farm agribusiness), subsector agribisnis hilir (downstream agribusiness) dan subsector jasa penunjang (supporting institution).

Perkembang teknologi dibidang pertanian (agribisnis) merupakan factor kritis sukses (critical success factor) bagi pertumbuhan dan perkembangan sector agribisnis di Indonesia. Perkembangan teknologi ini merupakan peluang besar yang harus dapat dimanfaatkan dalam rangka pencapaian tujuan Gapoktan.

\section{d. Faktor Sosial Budaya}

Adanya trend mengkonsumsi sayuran dalam jumlah banyak semakin berkembang dalam masyarakat modern di kota-kota besar. Trend tersebut dilatarbelakangi oleh semakin meningkatnya kesadaran masyarakar Indonesia akan kesehatan melalui pola makan yang sehat lebih mnegutamakan gizi yang dikandung dalam makanan. Trend tersebut dengan cepat dapat dilihat dibanyak supermarket yang menjual sayur mayor dalam bentuk kemasan yang menarik. Kebiasan baru ini merupakan salah satu pendorong peningkatan permintaan komoditas tersebut.

\section{V.2.2 Analisis Lingkungan Mikro \\ a. Pelanggan}

Pelanggan dalam dunia praktis dapat dibagi atas dua bagian besar, yakni pelanggan tetap dan pelanggan tidak tetap.. Pelanggan tetap merupakan mitra bisnis yang dilandasi dengan saling percaya dan jilai kejujuran. Pelanggan tetap merupakan asset yang sangat berharga bagi Gapoktan dalam menjalakan bisnis. Ada beberapa kuntungan yang dapat diambil dengan terjalinnya suatu kerjasama dengan pelanggan dalam jangka panjang, antara lain adalah: pelanggan membantu perusahaan (Gapoktan) dalam merencanakan proses produksi mulai dari waktu yang tepat untuk penanaman, jenis komoditi, kuantitas penanaman per jenis tanaman.. Salah satu contoh perusahaan yang mengadakan kerjasama dengan gapoktan adalah PT. Higreen yang dapat menampung Tomat Arthaloka dari gapoktan sebanyak 2 ton sekali pemesanan. Dalam seminggu dilakukan 2 kali pemesanan.

Gapoktan membangun komunikasi yang baik dengan semua pelanggan, hal ini sangat penting untuk mengantisipasi konflik-konflik yang terjadi atau agar Gapoktan lebih cepat menyerap kebutuhan dan keinginan pelanggan. Gapoktan juga menjalin kerjasama dengan pelanggan yang tidak tetap, 


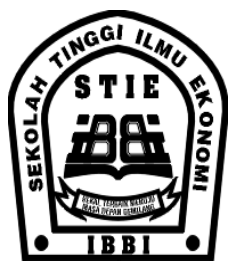

ISSN 1858-3199

JURNAL

MANAJEMEN BISNIS

STIE IBBI

dimana pelanggan lebih mengutamakan pencarian keuntungan sebesasr-besarnya. Hubungan yang terjadi lebih bersifat transaksib.

\section{b. Pesaing}

Pada dasarnya untuk mengindetifikasi tingkat persaingan dalam industry agribisnis dapat dikatakan relative masih sulit mengingat keterbatasan-keterbatasan informasi mengenai para pelaku agribisnis hortikultura diseluruh wilayah Indonesia.Disamping itu pasar untuk agribisnis terutama untuk sayur-sayuran masih terbuka luas bagi para pelaku agribisnis. Dan setiap pelaku agribisnis memiliki pasar sendiri yang dilayani. Beberapa perusahaan yang bergerak dalam bidang agribisnis hortikultura disekitar wilayah Jawa Barat:

- PT. Kurnia Alam Raya

- PT Putri Segar

- Kelompok Tani Padaboga

- Gabungan Kelompok tani Goalpara

- Dll

\section{c. Pemasok}

Untuk memenuhi kebutuhan pupuk dan pestisida serta benih/bibit pertanian, gapoktan menjalin kerjasama dengan beberapa produsen. Gapoktan menjalin kerjasama dengan PT Pupuk PUSRI Sukabumi dalam pemenuhan Gapoktan seperti Urea, ZA, dan sebagainya. Untukk pemenuhan bibit sayur Gapoktan menjalin kerjasama dengan PT. Nong Woo Bio Co., Ltd. Bila ditinjau dari sisi penyediaan tenaga kerja gapoktan berada pada wilayah dimana ketersediaan tenaga kerja tinggi. Sehingga dari suplai tenaga kerja Gapoktan tidak mendapatkan suatu masalah.

\section{V.2.3 Analisis Lingkungan Industri}

\section{a. Ancaman masuknya pendatang baru}

Ada beberapa factor yang melatarbelakangi kondisi ancaman masuknya pendatang baru dalam sector agribisnis, yakni: pendanaan, kebutuhan dana tinggiuntuk dapat terjun langsung dalam bidang agrisbis dapat dikatakan relative rendah. Aspek produk yang dibedakan dalam agribisnis yang dikenal dengan diferensiasi pasar belum begitu berkembang dengan baik. Untuk pasar-pasar tertentu diferensiasi produk sudah menjadi suatu keunggulan bersaing. Tetapi secara umum diferensiasi produk di dunia agribisnis belum begitu popular. Dari sisi sklaa ekonomi, sector ini dapat dimasuki oleh siapa saja tanpa harus menpersyarakatkan suatu besaran skala. Hanya semakin besar skala usaha memberikan keuntungan biaya produksi yang semakin menurun bagi pelaku bisnis serta memiliki daya tawar harga jual lebih baik. Dengan demikian tingkat ancaman perusahaan baru masuk kedalam sector agribisnis relative rendah.

\section{b. Persaingan antar perusahaan yang ada dalam industri.}

Tingkat persaingan antara perusahaan yang ada dalam industry agribisnis hortikultura relative rendah. Pasar yang masih terbuka luas pada tingkat domestic maupun internasional yang sepenuhnya belum tergarap oleh para pelaku agribisnis hortikultura. Terbukanya dan luasnya pasar merupakan factor yang besar yang mempengaruhi tingkat persaingan antara perusahaan.

\section{c.Daya tawar menawar pelanggan}

Sebagaimana ciri khas produk agribisnis yang mudah rusak, daya tawar menawar pelanggan relative tinggi terhadap produsen. Factor lain yang menyebabkan tingginya daya tawar menawar pelanggan adalah sifat lain produk agribisnis yakni standard kualitas yang bervariasi. 


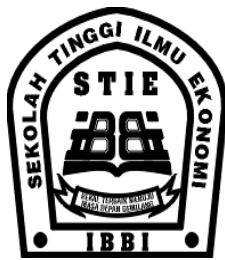

ISSN 1858-3199

JURNAL

MANAJEMEN BISNIS

STIE IBBI

\section{d.Daya tawar menawar pemasok}

Gapoktan merupakan lembaga yang mewadahi sejumlah kelompok petani hortikultura yang berkonsentrasi pada budidaya pertanian. Disamping konsentrasi pada budidaya pertanian, gapoktan juga memasrkan komoditi pertanian anggota. Pada konteks ini Gapoktan sebagai lembaga yang mewadahi para petani dalam memasarkan komoditi petani. Pemasok kepada Gapoktan terdiri dari suplai tenaga kerja dan pemasok input. Pada aspek pasokan tenaga kerja, Gapoktan beserta anggota tidak mendapatkan kesulitan untuk memenuhi kebutuhan tenaga kerja. Dari sisi pemasok input gapoktan juga sampai saat ini belum mendapatkan suatu hambatan yang berarti karena antara gapoktan sebagai perkumpulan petani memiliki hubungan yang baik dengan para suplai input pertanian mengingat Gapoktan merupakan pelanggan yang memiliki potensi penyerapan produk input pertanian.

\section{e.Ancaman produk pengganti}

Adanya kesamaan fungsi antara dua atau lebih jenis produk merupakan ancaman bagi suatu produk terhadap produk yang fungsinya sejenis. Untuk produk agribisnis sayur mayor ancaman produk pengganti adalah buah-buahan. Kedua komoditi pertanian ini memiliki fungsi yang sama sevafai sumber vitamin, mineral dan serat. Kesamaan fungsi kedua komodditi tersebut bukan serta merta produk yang penggunaannya/pemakaiannya dapat dipertukarkan secara langsung. Perbedaan yang nyata dari penggunaan kedua komodititersebut adalaah waktu konsumsi dimana komoditi sayur mayor dikonsumsi sebagai pelengkap makan. Dimana konsumsi buah-buahan lebih kepada makanan pencuci mulut. Dengan demikian buah-buahan bukanlah ancaman produk pengganti langsung dari sayur mayor bila dipandang dari sisi pola konsumsi kedua komoditi tersebut. Dengan demikian tingkat ancaman produk asubstitusi relative kecil.

\section{Formulasi Startegi Bersaing}

\section{VI.1 Identifikasi Faktor Internal dan Eksternal}

\section{VI.1.1 Faktor Kekuatan}

a. Areal Lahan Luas. Sebagaimana telah dipaparkan pada gambaran organsiasi (Bab IV) peluang gapoktan Goalpara sebagai sentra produsen komoditas sayur mayor untuk tingkat nasional kedepan didukung dengan luasan lahan tani kolektif 1575 ha yang dapat dikembangkan bagi pemebtnukan kawasan sentra produsen agribisnis sayur mayor.

b. Petani Terampil. Terampil yang dimaksud adalah penguasaan teknik budidaya sayur mayor yang disertai dengan pengalaman sebagai profesi petani dengan pengalaman diatas 10 tahun di wilayah Gapoktan.

c. Jenis Komoditi. Jenis komoditi yang beragam jumlahnya merupakan salah satu bentuk kekuatan Goalpara. Jenis komoditi yang banyak dijadikan factor kekuatan.

d. Jariangan Kelembagaan. Semakin luas suatu organisasi dalam menjalin dan memeliahra jaringan dengan lembaga lain merupakan salah satu factor kekuatan yang penting. Kerjasama dengan perusahaan pembibitan, pelanggan dan sebagainya

e. Kepastian pasar komoditi. Adanya jaringan kerjasama pemasaran dengan berbagai perusahaan pensuplai sayur mayur, dengan perusahaan swalayan (makro, Jakarta) merupakan bukti kekuatan bagi gapoktan

f. Citra Organisasi baik. Gapoktan telah dikenal dari beberapa wilayah di Indonesia sebagai salah satu organisasi yang berwawasan agribisnis. Hal ini dibuktikan dengan seringnya kunjungan-kunjungan yang dilakukan pelaku agribisnis ke Gapaoktan untuk berbagi informasi, serpti kunjungan pelaku agribisnis dari Kalimantan, sekitar Jawa Barat dsb. 
g. Penelitian dan Pengembangan. Telah dilaksanakannya penelitian dan pengembangan dilahan percobaan. Kegiatann yang berupa pengembangn pola tanaman, pembibitan bibit dan sebagainya.

h. Tanah dan Iklim. Ditinjau dari agroklimat wilayah Goalpara merupakan wilayah kerja gapoktan berada pada daerah pegunungan dengan ketinggian tempat antara $900-1300$ meter diatas permukaan laut, dengan suhu rata-rata 18-30 derajat celcius, curah hujan berkisar antara 2000 - $4000 \mathrm{~mm}$ pertahun serta kelembaban relative (RH) $85 \%$. Kondisi tanah didominasi oleh tanah latasol merah coklat dengan topografi landai, dengan iklim yang memiliki 3-4 bulan kering. Berdasarkan kondisi agroklimat yang ada diwilayah kerja Gapoktan maka sangat memenuhi persyaratan untuk menanam dan mengembangkan komoditas sayur mayor datran tinggi.

\section{VI.1.2 Faktor Kelemahan}

a. Belum terpenuhinya standard kualitas komoditi

b. Aspek manajemen. Belum adanya koordinasi anatara para pengurus gapoktan merupakan factor kelemahan yang harus dapat dibenahi kedepan

c. Semangat kemitraan rendah.

d. Belum orientasi pasar. Banyak jenis sayur mayor dengan tingkat permintaan tinggi pada pasar yang belum dapat digarap oleh gapoktan seperti: paprika, Buncis perancis dan sebagainya

e. Komitmen terhadap program. Komitmen menurun berbentuk pelanggan terhadap program Gapoktan yang telah disepakati bersama. Salah satu contoh adalah tidak memasarkan komoditi melalui gapoktan karena nilai jual relative lebih rendah daripada menjual sendiri.

f. Pemberdayaan anggota. Gapoktan belum secara baik menjalankan pola pembinaan anggota petani tradisional menjadi petani modern yang berwawasan agribisnis.

g. Tidak memiliki strategi besar. Tidak ada perencanaan secara strategis.

\section{VI.1.3 Faktor Peluang}

a. Suplai tenaga kerja. Ketersediaan tenaga kerja yang tinggi disekitar wilayah gapoktan Goalpara merupakan factor pendudukung pengembangn agribisnis.

b. Potensi pasar besar. Berdasarkan data ekspor dan impor, menunjukkan bahwa nilai dan volume impor Indonesia untuk saur mayor masih lebih tinggi dibandingkan nilai dan volume ekspor. Begitu juga berdasarkan pengalaman gapoktan dilapangan, potensi pasar kedepan tetap besar.

c. Kemajuan Teknologi. Perkembangan teknologi dibidang agribisnis kedepan semakin baik.

d. Kebijakan Pemerintah. Undang undang dan peraturan pemerintah sangat mendukung keberadaan pengembangan usaha mikro, kecil dan menengah dan koperasi serta agribisnis.

e. Konsumsi Sayur Mayur. Peningkatan pengelauran sayur mayor yang diakibatkan oleh adanya kenaikan pendapatan masyarakat dan kesadara kesehatan melalui makan sayur makin tinggi

\section{VI.1.4 Faktor Ancaman}

a. Fluatuasi harga. Belum adanya jaminan harga atas komoditas pertanian secara meluas.

b. Mahalnya harga input. Inflasi, suku bunga dan nilai tukar kurs sangat mempengaruhi produktifitas Gapoktan.

c. Isu Lingkungan. Tanah lahan yang sudah diolah dalam kurun waktu lama, akan meracuni tanah dan pada ujungnya akan menurunkan produktifitas tanah lahan.

d. Kondisi Politik. Instabilitas politik merupakan ancaman yang serius bagi pelaku bisnis. 


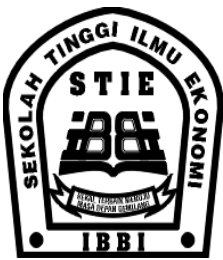

ISSN 1858-3199

JURNAL

MANAJEMEN BISNIS

STIE IBBI

e. Tingkat Suku Bunga. Tingginya suku bunga menghambat pengembanganagribisnis, dampaknya terhadap tingginya biaya produksi yang berimplikasi terhadap harga jual tinggi.

f. Jumlah Pesaing meningkat.

g. Persyaratan mutu produk tinggi. Kualitas tinggi yang tidak terpenuhi atau denan kata lain spesifikasi atas permintaan suatu komoditi tidak dapat terpenuhi oleh produsen merupakan ancaman perkembangan usaha kedepan.

\section{VI.2 Matriks IFE dan EFE}

\section{VI.2.1 Kekuatan}

Matrik Internal factor menunjukkan empat parameter kekuatan yang dimiliki Gapoktan, yakni: Kepastian pasar produk dengan peringkat diatas rata-rata pesaing, yaitu, 2,857 (rata-rata pesaing=2,5). Citra organisasi diatas rata-rata industry yakni: 2,714 (rata-rata pesaing=2,5). Citra yang kuat modal besar dalam hal pemasaran dan kepercayaan pelanggan/mitra kepada Gapoktan. Parameter terampil dengan peringkat 2,714, artinya anggota gapoktan memiliki keterampilan yang lebih baik dibandingkan pesaing. Parameter tanah dan iklim dengan peringkat 3,00, yang berarti bahwa lahan dan lokasi Gapoktan sangat sesuai untuk pengembangan agribisnis

\section{VI.2.2 Kelemahan}

Faktor standar mutu komoditi yang bervariasi dengan peringkat 2,286 dibandingkan standard rata-rata pesaing. Artinya factor ini relative lebih lemah/rendah dibandingkan standard mutu rata-rata. Parameter lain adalah fungsi manajemen yang belum atau tidak berjalan. Ini ditandai peringkat Gapoktan untuk aspek manajemen sebesar 3.00 (lemah disbanding pesaing)

\section{VI.2.3 Peluang}

Parameter terbesar yang diberi bobot adalah potensi pasar domestic dan luar negeri dengan bobot o,095 dengan peringkat Gapoktan dalam industry agribisnis sebesar 3,571, yang berarti gapoktan dalam merespon peluang potensi pasar sangat baik.

\section{VI.2.4 Ancaman}

Parameter flutuasi harga dengan bobot 0,092 dengan peringkat nilai 2,571 berarti gapoktan memiliki posisi yang relative dapat mengatasi dan merespon ancaman fluktuasi harga komoditi. Parameter harga input diberi bobot 0,089 dengan peringkat 2,714 yang berarti bahwa Gapoktan memiliki posisi yang relative dapat mengatasi mahalnya harga input pertanian.

\section{VI.3 Analisa Matrik Internal dan Eksternal}

Matrik Internal-Eksternal merupakan hasil pengolahan dari Matrik IFE dan EFE. Dari matrik EFE nilai yang dihasilkan sebesar 2,849 merupakan sumbu vertical dengan range nilai mulai dari 1,00 sampai dengan 4,00. Nilai factor EFE berada diatas nilai 2,5. Ini berarti bahwa perusahaan dalam keadaan yang ada pda saat ini relative dapat memanfaatkan peluang serta memiliki kemampuan untuk menghadapi ancaman dari lingkungannya. Matriks IFE diatas rata-rata $(2,5)$ yakni 2,660. Angka ini menggambarkan posisi internal Gapoktan cukup kuat untuk dapat memanfaatkan peluang dari lingkungan luar serta memiliki kemampuan untuk menghindari ancaman dari lingkungan luar Gapoktan.

Dari hasil pemetaan skor IFE dan EFE, Gapoktan Goalpara berada pada kuadran V dengan strategi Growth (konsentrasi melalui integrasi horizontal) dan Stability (tak ada perubahan startegi)

Dengan posisi yang dimiliki perusahaan dimana gapoktan berada pada posisi hold dan maintain (growth and stability) maka startegi yang disarankan oleh David (1997) adalah startegi penetrasi pasar dan pengembangan produk. 


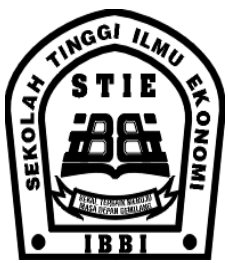

ISSN 1858-3199

JURNAL

MANAJEMEN BISNIS

STIE IBBI

Strategi penetrasi pasar adalah strategi untuk meningkatkan pangsa pasar produk atau jasa yang ada pada saat ini untuk pasar lama (pasar yang telaha da) melalui suatu usaha pemasaran. Strategi pengembangan produk adalah startegi untuk meningkatkanpenjualan melaluiperbaikan atau modifikasi produk atau jasa lama.

\section{VI.4 Analisa SWOT}

Analisa SWOT merupakan analisis perusahaan atau organsiasi dengan mengkaji lingkungan internal maupun eksternalnya. Dari analisis ini dapat dirumuskan alternative-alternatif strategi yang didasari oleh kekuatan-kelemahan Gapoktan dan peluang-ancaman dari luar lingkungan gapoktan. Matriks SWOT memberikan beberpa alternative startegi yang dapat digunakan Gapoktan dalam emnjalankan usaha kedepan. Startegi-strategi yang berhasil dirumuskan diatas berdasar analisis terhadap factor internal dan luar Gapoktan.

\section{VI.4.1 Strategi Kekuatan peluang}

a. Strategi Kekuatan-Peluang

Beberapa strategi yang dihasilkan adalah:

1. Strategi Penetrasi pasar. Strategi ini focus terhadap perluasan pasar melalui usaha pemasaran dengan tujuan untuk meningkatkan penjualan komoditi dipasar sekarang

2. Strategi Integrasi Usaha. Strategi ini beroreintasi kedalam organisasi dengan mengidentifiksi seluruh sumber daya anggota petani gapoktan Goalpara, memetakan kondisi saat ini - meliputi identifikasi jenis-jenis kegaitan per anggota petani baik kegiatan pada on farm ataupun off farm. Tujuan strategi ini adalah untuk memfokuskan usaha dengan mempertimbnagkan sumber daya yang dimiliki dengan sasaran dapat mersponkebtuuhan dan keingnan pasar baik domestic maupun luar negeri

b. Strategi Kekuatan-Ancaman

1. Penetapan Segemen dan Pasar Sasaran serta Market Positioning. Gapoktan harus dapat menetapkan bagian pasar yang harus digarap dan lebih jauh lagi adalah focus terhadap satu atau lebih sasaran pasar untuk dilayanis secara lebih baik. Dan akhirnya gapoktan harus menciptakan dan memelihara citra gapoktan yang spesifik dimata stakeholders.

2. Startegi Integrasi Vertikal. Startegi ini menghasilkan pertumbuhan melalui akuisisi organsiasi lain yang terdapat dalam saluran distribusi. Stargei ini bertujuan untuk memperoleh control yang lebih besar atas suatu line of business. Ada dua jenis integrasi vertical:

- Backward Integration. Pada kasus ini gapoktan berusaha menguasai suplai untuk beberapa pupuk dan pestisida, alat-alat pertanian, bibit atau benih. Tujaunnya adalah efisiensi dengan suplai sendiri kebutuhan gapoktan

- Forward Integration. Pada kasus ini gapoktan membeli atau menguasai perusahaan yang lebih dekat dengan konsumen seperpti pedagang besasr, eceran dsb. Pada konteks ini orientasi oeprasi adalah memasarkan sendiri komoditi yang diproduksi.

3. Strategi Unggul Biaya. Strategi ini merupakansalah satu usaha untuk meningkatkan daya saing komoditi pertanian ditengah-tengah persaingan dalam industry agribisnis. Ada beberapa cara untuk strategi unggul biaya: control ketat pada setiap kegiatan ekonomi agribisnis mulai dari proses penyediaan saprodi, budidaya sampai pasca panen. 


\section{c. Strategi Kelemahan- Peluang}

Beberapa startegi yang dihasilkan:

1. Strategi peningkatan kualitas produk pertanian. Pada konteks persaingan, salah satu factor keberhasilan adalah pemenuhan standard kualitas sayur mayur yang diminta pembeli. Kualitas sayur mayor berhubungan dengan kondisi komoditi, yakni: penampilan-warna, tingkat kematangan-umur, ukuran, serta pengemasan yang dipersyaratkan pembeli.

2. Konsolidasi Manajemen. Konsolidasi manajemen dapat diartikan sebagai suatu usaha mempererat, memperutuh hubungan interaksi baik itu interaksi antara divisi, antar individu, penyamaan an penumbuhan visi.

3. Membnagun system informasi pasar. Melalui system informasi pasar manajemen dapat menghasilkan data-data terkait dengan kebutuhan perusahaan. Melalui pembngunan system informasi agribisnis yang baik perusahaan agribisnis dapat melihat keseimbangan antara penawaran dan permintaan komoditi pertanian dalam suatu kurun waktu pada pasar dan waktu tertentu.

\section{d. Strategi Kelemahan - Ancaman}

1. Strategi peningkatan kualitas produk.

2. Peningkatan kualitas sumber daya manusia.

3. Sosialisasi visi dan misi secara kesenambungan

\section{Kesimpulan dan Saran}

\section{Kesimpulan}

1. Visi Gapoktan sudah menggambarkan pola pertanian yang berwawasan agribisnis

2. Gapoktan sebagai gabungan kelompok tani telah mampu memposisikan disi sebagai salah satu produsen sayur mayur di industry hortikultura di Indonesia khususnya di wilayah Jawa Barat

3. Berdasarkan analisi lingkungan Makro, menunjukkan indikasi peluang atau prospek agribisnis hortikultura pada masa depan semakin cerah

4. Analisis lingkungan Mikro menunjukkan bahwa beberapa factor yang memberi pengaruh terhadap pengembangan agribisnis menunjukkan iklim kondusif, suplai tenaga kerja baik, kebutuhan saprodi mencukupi dsb

5. Analisis indsutri menunjukkan bahwa industri agribisnis hortikultura memiliki ketertarikan tinggi bagi investor. Pasar yang luas, tingkat persiangan relative rendah pada levelmengarah kepada usaha komersial industry, biaya beralih rendah, diferensiasi sayur mayor belum kuat.

Saran

1. Gapoktan sebaiknya dalam mengelola organsiasi secara professional dengan menerapkan konsep kesatuan/keutuhan bisnis, dimana para pengurus Gapoktan harus sadar memilahmilah kepentingan pribadi dengan kelompok

2. Gapoktan menciptakan sebuah struktur organsiasi yang dapat mengakomodir terlaksananya strategi.

3. Menempatkan orang terbaik pada tempat semstinya sehingga strategi Gapoktan dapat dijalankan

4. Perlu dipertimbangkan untuk meningkatkan legaslitas/aspek hokum kelompok tani menjadi suatu badan hokum seperti CV atau PT kedepannya..

5. Ada 2 saran bertahap yang dapat dilaksanakan sehubungan dengan hasil formulasi dari strategi bersaing sbeagai berikut: 


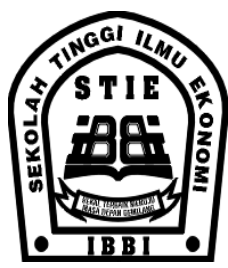

ISSN 1858-3199

JURNAL

MANAJEMEN BISNIS

STIE IBBI

a. Sasaran tahap pertama

- Strategi sosialisasi visi dan misi secara berkesinambungan

- Strategi integrasi usaha

- Strategi segmentasi, targeting dan positioning

- Strategi penetrasi pasar

- Strategi unggul biaya

- Strategi peningkatan kualitas komoditi

- Startegi peningkatan peningkatan kualitas usmber daya

b. Sasaran tahap kedua

- Strategi integrasi vertical.

- Membangun system informasi pasar

\section{DAFTAR PUSTAKA}

David, Fred. 1999. Strategic Management, Seventh Edition. New Jersey: Prentice Hall, Inc.

Hamel, G \& Prahald C.K. 1998. Kompetisi Masa Depan. Harvard Business School Press

Porter, Michael E. 1994. Keunggulan Bersaing. Binarupa Aksara

Suwarno. 19996. Manajemen Strategik. YKPN, Yogyakarta

Gibson, Rowan. Rethinking the Future. 1998. PT. Gramedia Pustaka Utama, Jakarta

Rangkuti, F. 1999. Analisis SWOT Teknik Membedah Kasus Bisnis. PT. Gramedia Pustaka Utama. Jakarta

Pearc, J.A dan R.B. Robinson. 1997. Startegic Managemennt: Formulation, Implementation, amd Controll. Sixth Edition. USA: Richard D. Irwin

Jauch L. R.dan W.F.Glueck. 1994. Manajemen Strategi dan Kebijakan Perusahaan. Penerbit: Air Langga

Nuhung, H.I. 2000. “ startegi PengembanganAgribisnis berorientasi Ekspor Yang Berkelanjutan: Seminar nasional INAGRI, Istora Senayan, Jakarta

Faulkner, D. dan Johnson, G 1995. Startegi Manajemen. Seri Stratgei Manjamen. Penerbit: Elex Media Komputindo, Jakarta.

Solahuddin, S. 1999. Diskusi Panel: “ Penggalangan Agribisnis sebagai leading sector menghadapi Era AFTA dan APEC: Tinjauan Strategik Kebijakan:. 22 Februari 1999, Hotel Horison, Jakarta

Render, B \& Heizer, J. 1997. Principles of Operation Management2nd. Prentice Hall. Inc. New Jersey 


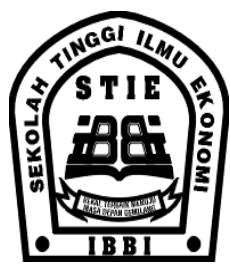

ISSN 1858-3199

JURNAL

MANAJEMEN BISNIS

STIE IBBI

\title{
Penggunaan Teknik Rantai Markov Dalam Model Prediksi Perpindahan Merek Konsumen Sepeda Motor Matik (Studi Kasus Pada Mahasiswa STIE IBBI Medan)
}

\author{
Edison Parulian \\ Dosen Tetap STIE IBBI Medan
}

\begin{abstract}
Abstrak
Fenomena pergeseran pangsa pasar sepeda motor nasional yang saat ini didominasi oleh jenis sepeeda motor matik akan menyebabkan persaingan yang sengit diantara merek dan jenis sepeda motor matik. Penelitian ini bertujuan untuk membuat sebuah model perpindahan merek (brand switching) untuk membuat sebuah peramalan perubahan pangsa pasar merek dan jenis sepeda motor matik pada kalangan mahasiswa di STIE IBBI Medan.

Hasil peneltian menunjukkan bahwa Honda Vario diprediksi akan menguasai pangsa pasar sepeda motor matik, dimana mengalami peningkatan paling signifikan sekitar 18 persen. Ini memnyebabkan pangsa pasar awal Honda vario yang pada awalnya sebesar 31,25 persen diprediksi pada masa yang akan datang akan menjadi 49,15 persen, kondisi ini disebabkan karena Honda Vario relatif memiliki lebh besar konsumen yang loyal.lSedangkan seluruh jenis dan merek sepeda motor lainnya diprediksi akan mengalami penurunan serta relatif stagnan.
\end{abstract}

\section{PENDAHULUAN}

Sarana transportasi sepeda motor sampai saat ini masih merupakan produk yang paling diminati oleh sebagian besar masyarakat dengan beberapa pertimbangan utama yakni dari sisi harga yang relatif terjangkau, biaya operasional dan perawatan yang cukup murah, serta lebih praktis digunakan khususnya dalam situasi kepadatan jalan di kota-kota besar.

Salah satu fenomena dalam industri sepeda motor adalah pergeseran minat konsumen terhadap jenis sepeda motor yang ditawarkan produsen-produsen besar sepeda motor di Indonesia. Jika dalam tiga dasawarsa pangsa pasar produk sepeda motor didominasi oleh jenis sepeda motor manual (manual scooter) atau lebih dikenal dengan istilah "bebek", maka dalam 3-4 tahun terakhir ini pangsa pasar bergeser dan didominasi oleh jenis sepeda motor CVT (continuous variable transmission) atau yang lebih kita kenal dengan istilah sepeda motor matik.

Data hasil penjualan sepeda motor di Indonesia periode 2013 yang diperoleh dari Asosiasi Industri Sepeda Motor Indonesia (AISI) menunjukkan bahwa dari 10 jenis sepeda motor dengan penjualan terbesar di tahun 2013 tiga penjualan terbesar adalah sepeda motor matik yakni: Honda Beat dengan penjualan 1.856.637 unit, kemudian diikuti oleh Honda Vario dengan penjualan 1.314.685 unit, dan Yamaha Mio (all variants) dengan penjualan 1.139.217 unit. Sedangkan satu jenis lagi sepeda motor matik yang termasuk dalam daftar 10 penjualan terbesar adalah jenis Honda Scoopy dengan penjualan 200.421 unit.

Selanjutnya jika dibandingkan dengan total penjualan sepeda motor di Indonesia pada tahun 2013 yang diperoleh dari AISI yaitu sebesar 7,771,014 unit, maka hanya dari keempat jenis sepeda motor matik yang masuk dalam 10 penjualan terbesar itu saja pangsa pasar sepeda motor matik memiliki 


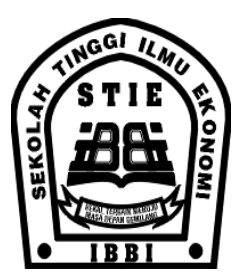

ISSN 1858-3199

JURNAL

MANAJEMEN BISNIS

STIE IBBI

bagian sebesar 58 persen total penjualan. Belum termasuk beberapa jenis sepeda motor matik lain yang tidak termasuk dalam 10 penjualan terbesar di tahun 2013.

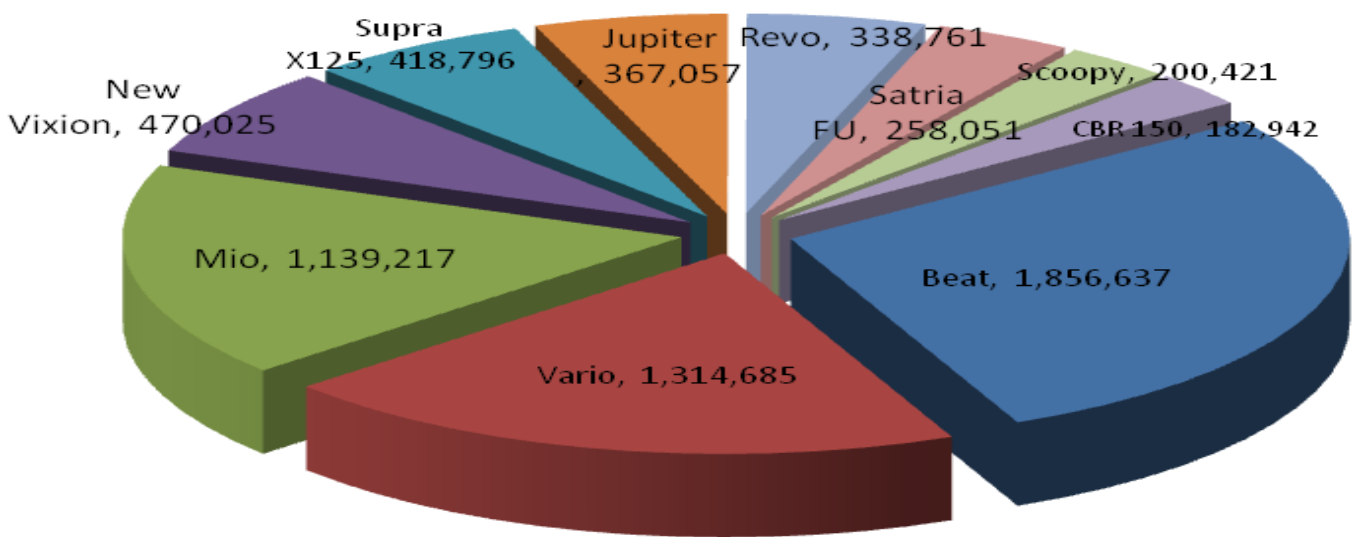

Sumber: AISI

Diagram 1

Sepuluh Jenis Sepeda Motor Dengan Penjualan Terbesar Tahun 2013

Keberhasilan strategi pemasaran sepeda motor matik di Indonesia merupakan keberhasilan mematahkan stigma konsumen sepeda motor di Indonesia akan sulitnya perawatan dan suku cadang sepeda motor matik. Hal ini dilakukan dengan menunjukkan nilai-nilai kepraktisan sepeda motor matik dibandingkan dengan menggunakan sepeda motor bertransmisi manual di kepadatan jalan kota misalnya, serta iklan dan promosi yang menonjolkankan fitur-fitur dan kecanggihan teknologi yang berbeda, misalnya dengan kapasitas mesin yang besar, menggunakan radiator sebagai alat pendingin, fitur side stand switch, parking brake lock, idling stop, dan lain sebagainya.

Sengitnya persaingan antara produsen merek merek sepeda motor khususnya sepeda motor matik dimasa yang akan datang tidak mungkin dielakkan, setiap produsen akan senantiasa melakukan upaya-upaya untuk meningkatkan citra merek (brand image) masing-masing produknya dengan melakukan berbagai macam cara dengan tujuan utama menciptakan konsumen dengan loyalitas tinggi terhadap merek produksi mereka, sekaligus meminimalisasi perpindahan merek oleh konsumen ke produk pesaing mereka.

Perpindahan merek (brand switching) atau dikenal juga dengan istilah brand jumping menjadi penting, karena menunjukkan langsung sebuah kondisi dimana ditemukan kenyataan bahwa seorang konsumen telah meninggalkan sebuah merek produk yang telah rutin digunakannya dan menggunakan merek produk lain yang sejenis. Jika kecenderungan konsumen untuk melakukan perpindahan merek dapat dimodelkan dan diukur maka akan sangat berguna bagi strategi pemasaran perusahaan. Perusahaan juga akan dapat melakukan prediksi pangsa pasar di masa depan dan memposisikan pangsa pasar produk mereka dibandingkan dengan merek pesaingnya (Chaarlas \& Rajkumar, 2012). 


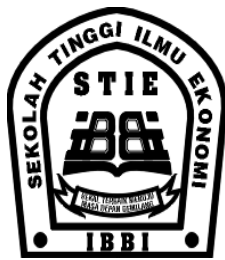

ISSN 1858-3199

JURNAL

MANAJEMEN BISNIS

STIE IBBI

Penggunaan matriks transisi dalam analisis rantai Markov untuk pemodelan perpindahan merek oleh konsumen, serta selanjutnya memprediksi kondisi pangsa pasar suatu produk terhadap pesaingnya telah banyak digunakan dalam analisis pemasaran. Penggunaan matriks transisi Markov dalam prediksi kondisi pangsa pasar di masa depan dipelopori oleh oleh Styan dan Smith dalam sebuah penelitian yang dirilis 1964 . Penelitian mereka menunjukkan potensi pengembangan analisis rantai Morkov dalam penelitian pemasaran dan telah banyak dikembangkan seperti Datong (2011), Djan dan Ruvendi (2006), Awogbemi dkk (2012), Hatidja dkk (2013), Oseni (2013) dan banyak penelitian lainnya.

Nilai-nilai probabilitas yang dihasilkan dalam analisis rantai Markov walaupun tidak secara langsung memberikan rekomendasi sebuah keputusan akan tetapi akan sangat membantu memberikan informasi penting mengenai situasi keputusan yang dapat membantu pengambil keputusan. Nilai-nilai probabilitas misalnya akan memberikan informasi kepada manejer pemasaran untuk melakukan tindakan-tindakan perbaikan dengan melakukan perbandingan tingkat intensitas yang didapat dalam beberapa periode waktu dengan siklus hidup produknya (product life cycle)

\section{LANDASAN TEORITIS}

\section{Analisis Rantai Markov}

Analisis rantai Markov seara garis besar adalah sebuah teknik untuk memprediksi perubahan atau pergerakan variabel-variabel diwaktu yang akan datang berdasarkan pergerakan variabel

diwaktu sekarang. Analisis Markov diterapkan terutama pada sistem yang menampilkan pergerakan probabilitas dari satu keadaan ke keadaan lainnya sepanjang waktu sehingga Analisis Markov merupakan suatu bentuk khusus dari model probabilistik yanglebih umum yang dikenal sebagai proses stokastik (stochastic process).

Proses stokastik $X=\{X(t), t \in T\}$ menunjukkan sebuah barsian peubah acak, yaitu untuk setiap $t \in T$ kita mempunyai $\mathrm{X}(\mathrm{t})$. sedangkan $\mathrm{t}$ sendiri sering di intrepretasikan sebagai variabel waktu dikarenakan proses stokasstik sering kali dihubungankan dengan suatu selang waktu. Nilai peubah $\mathrm{X}(\mathrm{t})$ disebut sebagai dengan state/peristiwa pada saat $\mathrm{t}$. Himpunan $\mathrm{T}$ disebut ruang parameter atau ruang indeks dari proses stokastik $\mathrm{X}$ dan himpunan nilai $\mathrm{X}(\mathrm{t})$ yang dinamakan ruang state dari $\mathrm{X}$. (Papoulis, 1992), (Hasdianti, 2006)

Jika pada waktu proses $\mathrm{t}$ proses stokastik $\{\mathrm{Xt}, \mathrm{t}=0,1, \ldots \ldots\}$ berada pada state $\mathrm{i}$, maka kejadian ini ditulis sebagai $X_{t}=i$. Proses stokastik memiliki sifat khusus yaitu untuk semua $i_{o}, \ldots . i_{t-1}, I, j$ dan semua $\mathrm{t} \geq 0$ berlaku:

$P\left\{\left\{X_{t+1} \mid X_{0}=i_{0}, \ldots, X_{t-1}=i_{t-1}, X_{t}=i\right\}=P\left\{X_{t=1}=j \mid X_{t=1}\right\}\right\}$

Sebuah rantai Markov dapat dibentuk menjadi sebuah matriks transisi rantai Markov dimana rantai Markov $\{\mathrm{Xt}, \mathrm{t}=0,1, \ldots \ldots\}$ dengan ruang state $\{0,1, \ldots . \mathrm{M}\}$ yang berarti peluang sistem itu dalam state i pada suatu state $\mathrm{j}$ dilambangkan dengan $\mathrm{T}_{\mathrm{ij}}$ dan disebut peluang transisi dari state $\mathrm{i}$ ke state $\mathrm{j}$. Matriks $\mathrm{T}=\left[\mathrm{p}_{\mathrm{ij}}\right]$ disebut matriks transisi rantai Markov (Horward dan Rorres,2004) 


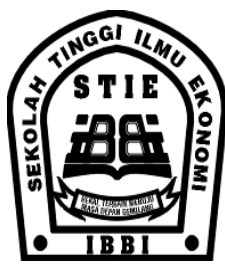

ISSN 1858-3199

JURNAL

MANAJEMEN BISNIS

STIE IBBI

$\mathrm{T}=\left\lfloor\begin{array}{cccc}p_{00} & p_{01} & \ldots & p_{0 M} \\ p_{10} & p_{11} & \ldots & p_{1 M} \\ \vdots & \vdots & \vdots & \vdots \\ p_{M 0} & p_{M 1} & \ldots & p_{M M}\end{array}\right\rfloor$

Nilai peluang setiap state akan mengalami perubahan jika sebuah matrik transisi mengalami proses transisi. Hiller dan Liberman (2008) mendefenisikan kondisi ini sebagai $n$-step $T_{i j}^{(n)}$ adalah peluang bersyarat sustu sistem matriks transisi (T) setelah proses:

$T_{i j}^{(n)}=P\left\{X_{t+n=j} \mid X_{t}=1\right\}$

Oleh karena $T_{i j}^{(n)}$ adalah peluang bersyarat, nilai peluang harus bernilai tak negatif dan oleh karena prosesnya harus membuat perubahan ke state yang lain maka peluang tersebut harus memenuhi harus memenuhi sifat:

- $\quad T_{i j}^{(n)}>0$ untuk semua $i$ dan $j ; n=1,2, \ldots .$.

- $\quad \sum_{j=0}^{M} T_{i j}^{(n)}=1$ untuk semua $i$ dan $j ; n=1,2, \ldots .$.

Adapun matriks peluang untuk transisi $n$-step ketika $\mathrm{n}=1$, maka $T_{i j}^{(1)}=\mathrm{p}_{\mathrm{ij}}$

$\mathrm{T}^{(\mathrm{n})}=\left[\begin{array}{cccc}p_{00}{ }^{(n)} & p_{01}{ }^{(n)} & \ldots & p_{0 M}{ }^{(n)} \\ p_{10^{(n)}} & p_{11^{(n)}}{ }^{(n)} & \ldots & p_{1 M^{(n)}} \\ \vdots & \vdots & \vdots & \vdots \\ p_{M 0}{ }^{(n)} & p_{M 1}{ }^{(n)} & \ldots & p_{M M^{(n)}}\end{array}\right]$

Untuk menghitung peluang transisi transisi dalam n-step digunakan persamaan Chapman danKolgomorov dengan:

$T_{i j}^{(n)}=\sum_{k=0}^{M} T_{i k}^{(m)} T_{k j}^{(n-m)}$

untuk semua $i, j=0,1, \ldots . . M: m=1,2 \ldots ., n-1 ; n=m+1, m+2, \ldots \ldots$

Persamaan (5) sekaligus menunjukkan bahwa proses perubahan dari state ke $i$ ke state $j$ sebanyak $n$ step akan berada dalam beberapa state $\mathrm{k}$ setelah tepat $\mathrm{m}$ (kurang dari $\mathrm{n}$ ) state. Oleh karena itu $T_{i k}^{(m)} T_{k j}^{(n-m)}$ adalah peluang bersyarat dengan titik mulai state $\mathrm{i}$, proses menuju ke state $\mathrm{k}$ setelah $\mathrm{m}$ step dan kemudian ke state j setelah n-m step. Dengan demikian penjumlahan peluang bersyarat terhadap semua k yang mungkin menghasilkan $T_{i k}^{(n)}$. Hiller dan Liberman, 2008)

Suatu state atau keadaan pada rantai Markov yang ditulis dalam bentuk vektor dinamakan state vektor atau vektor keadaan.(Horward dan Rorres, 2004). Vektor state untuk sebuah pengamatan pada suatu rantai Markov dengan X(t) state adalah vektor baris $\mathrm{x}$. dapat dituliskan $x=\left[x_{1} x_{2}, \ldots . x_{i}\right]$ dimana masing-masing notasi menunjukkan peluang sebuah sistem matriks transisis berada pada state ke $i$. Jika $\mathrm{T}$ merupakan matriks transisi rantai Markov dan $x^{n}$ adalah vektor state pada pengamatan ke- $n$ maka $x^{n}=T^{n} x^{0}$ 


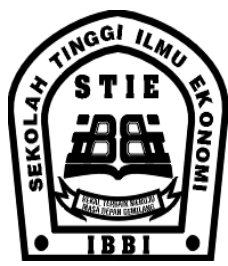

ISSN 1858-3199

JURNAL

MANAJEMEN BISNIS

STIE IBBI

Perpindahan Merek (Brand Switching)

Perpindahan merek adalah beralihnya konsumen yang telah secara rutin menggunakan suatu merek produk ke penggunaan atau pembelian merek produk lain yang biasanya sejenis. Menurut Umeshanand (2008) beberapa faktor penting yang menyebabkan terjadinya perpindahan merek adalah:

- Ketidakkonsistenan penempatan posisi merek suatu produk (brand positioning).

- Rendahnya tindakan riset dan pengembangan yang dilakukan perusahaan bagi pengembangan produknya.

- Pelanggan merasa tidak nyaman akan produk akibat turunnya kualitas produk.

- Ketidakmampuan perusahaan mengembagkan variasi jenis produk.

- Keunikan dan variasi di merek produk pesaing

- Peningkatan harga produk

- Tidak tercitanya konsumen yang loyal terhadap merek produk tersebut.

\section{Metode Penelitian}

\section{Data dan Teknik Pengumpulan Sampel}

Data yang digunakan adalah data primer dengan target populasi adalah mahasiswa STIE IBBI yang menggunakan sepeda motor matik sehari-harinya selama periode penelitian yang dilakukan Januari hingga Februari 2014.

Teknik pengambilan sampel yang digunakan dalam penelitian ini adalah Non- Probability Sampling, yaitu setiap unsur dalam populasi tidak memiliki kesempatan atau peluang yang sama untuk dipilih sebagai responden (sampel), bahkan probabilitas anggota populasi tertentu untuk terpilih tidak diketahui. Jenis Non Probabilitas Sampling yang digunakan adalah Convenience Sampling, yang merupakan metoda pemilihan sampel berdasarkan faktor kemudahan yang ditentukan sendiri oleh peneliti. Responden yang dipilih dalam penelitian ini adalah mahasiswa yang didapatkan menggunakan sepeda motor matik pada saat ke kampus. Sedangkan ukuran sampel yang diambil berjumlah 80 responden dimana penentuan besarnya jumlah sampel ini didasarkan atas pertimbangan keterbatasan waktu dan biaya.

\section{Tahapan Analisis Rantai Markov}

Tahapan-tahapan analisis Markov yang dilakukan pada penelitian ini mengacu pada penelitian Djan dan Ruvendi, 2006 sebagai berikut:

1. Membuat tabel jumlah pengguna sepeda motor matik masing-masing jenis sepeda motor matik pada saat penelitian. Adapun produk sepeda motor matik dibedakan berdasarkan jenisnya sehingga walaupun BEAT, Vario, dan Scoopy adalah satu produsen yakni PT. AHM tetap dibedakan karena jenis dan sasaran pemasarannya dianggap berbeda.

2. Membuat tabel perpindahan merek yaitu data perubahan atau peralihan dari suatu merek/jenis sepeda motor matik ke merek lainnya.

3. Membuat matrik peluang transisi $(\mathrm{T})$

4. Memprediksi pangsa pasar menggunakan rumus $x^{n}=T^{n} x^{0}$ dimana diasumsikan matriks transisi $\mathrm{T}$ bersifat stabil/konstan. 


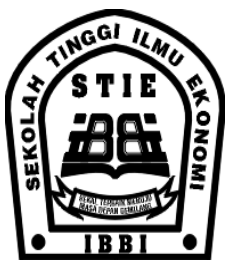

ISSN 1858-3199

JURNAL

MANAJEMEN BISNIS

STIE IBBI

\section{HASIL DAN PEMBAHASAN}

Jenis dan Merek Sepeda Motor Yang Digunakan

Dari hasil pengumpulan data sampel diperoleh jenis dan merek sepeda motor matik yang digunakan oleh mahasiswa STIE IBBI Medan adalah sebagai berikut:

Tabel 1. Jenis dan Merek Sepeda Motor Yang Digunakan

\begin{tabular}{|l|l|c|c|}
\hline No & Jenis/Merek & $\begin{array}{c}\text { Jumlah } \\
\text { Responden }\end{array}$ & $\begin{array}{c}\text { Proporsi } \\
(\boldsymbol{\%})\end{array}$ \\
\hline 1 & BEAT (A) & 22 & 27.50 \\
\hline 2 & VARIO (B) & 25 & 31.25 \\
\hline 3 & MIO (C) & 19 & 23.75 \\
\hline 4 & SCOOPY (D) & 9 & 11.25 \\
\hline 5 & Others (E) & 5 & 6.25 \\
\hline & & 80 & 100 \\
\hline
\end{tabular}

Data pada tabel 1 menunjukkan bahwa pengguna Honda Vario memiliki proporsi terbesar dengan nilai 31,25 persen diikuti oleh pengguna Honda Beat dengan persentase 27,50 persen, selanjutnya Yamaha Mio dengan 23,75 persen dan Honda Scoopy dengan 11,25 persen. Sedangkan sisanya sebanyak 5 responden menggunakan motor matik dari jenis dan merek lain.

\section{Perpindahan Merek dan Jenis Sepeda Motor Matik}

Selera konsumen selalu berubah dalam menggunakan suatu produk. Perpindahan merek dan jenis sepeda motor matik adalah hal yang umum terjadi dikalangan pengguna sepeda motor. Untuk melihat pergeseran selera atau perpindahan konsumen dari satu merek dan jenis sepeda motor ke merek dan jenis sepeda motor lainnya dapat dilihat pada tabel berikut.

Tabel 2. Perpindahan Jenis dan Merek Sepeda Motor Matik

\begin{tabular}{|c|c|c|c|c|c|c|c|c|c|c|c|c|c|}
\hline No & Jenis/Merek & \multirow{2}{*}{$\begin{array}{c}\text { Kondisi } \\
\text { Awal }\end{array}$} & \multicolumn{5}{|c|}{ Gains From } & \multicolumn{5}{|c|}{ Losses from } & \multirow{2}{*}{$\begin{array}{c}\text { Net } \\
\text { Gains/Losses }\end{array}$} \\
\hline & & & $\bar{A}$ & B & $\mathrm{C}$ & D & $\mathbf{E}$ & $\bar{A}$ & B & $\mathbf{C}$ & D & $\mathbf{E}$ & \\
\hline 1 & BEAT (A) & 22 & 0 & 2 & 2 & 1 & 0 & 0 & 5 & 2 & 3 & 2 & -7 \\
\hline 2 & VARIO (B) & 25 & 5 & 0 & 3 & 2 & 1 & 2 & 0 & 1 & 2 & 0 & 6 \\
\hline 3 & $\mathrm{MIO}(\mathrm{C})$ & 19 & 2 & 1 & 0 & 4 & 1 & 2 & 3 & 0 & 1 & 1 & 1 \\
\hline 4 & $\begin{array}{l}\text { SCOOPY } \\
\text { (D) }\end{array}$ & 9 & 3 & 2 & 1 & 0 & 1 & 1 & 2 & 4 & 0 & 1 & -1 \\
\hline 5 & Others $(E)$ & 5 & 2 & 0 & 1 & 1 & 0 & 0 & 1 & 1 & 1 & 0 & 1 \\
\hline & & 80 & & & & & & & & & & & \\
\hline
\end{tabular}

Sumber: Data Penelitian

Tabel 3. Kondisi Awal dan Akhir Pangsa Pasar Sepeda Motor Matik

\begin{tabular}{|l|l|c|c|c|c|c|c|}
\hline No & Jenis/Merek & \multicolumn{9}{|c|}{ ke } & \multicolumn{2}{c|}{$\begin{array}{c}\text { Kondisi } \\
\text { Awal }\end{array}$} \\
\hline & & A & B & C & D & E & 22 \\
\hline 2 & BEAT (A) & 10 & 5 & 2 & 3 & 2 & 25 \\
\hline 3 & VARIO (B) & 2 & 20 & 1 & 2 & 1 & $\mathbf{2}$ \\
\hline 4 & SCOOPY (C) & 2 & 3 & 12 & 1 & 1 & $\mathbf{9}$ \\
\hline 5 & Others (E) & 0 & 2 & 4 & 1 & 1 & $\mathbf{5}$ \\
\hline & Kondisi Akhir & $\mathbf{1 5}$ & $\mathbf{3 1}$ & $\mathbf{2 0}$ & $\mathbf{8}$ & $\mathbf{6}$ & $\mathbf{8 0}$ \\
\hline
\end{tabular}

Sumber: Data Penelitian 
Dari tabel perpindahan merek tersebut dapat disusun sebuah matriks transisi (T) sebagai berikut:

$$
\mathrm{T}=\left(\begin{array}{ccccc}
10 / 22 & 5 / 22 & 2 / 22 & 3 / 22 & 2 / 22 \\
2 / 25 & 20 / 25 & 1 / 25 & 2 / 25 & 0 / 25 \\
2 / 19 & 3 / 19 & 12 / 19 & 1 / 19 & 1 / 19 \\
1 / 9 & 2 / 9 & 4 / 9 & 1 / 9 & 1 / 9 \\
0 / 5 & 1 / 5 & 1 / 5 & 1 / 5 & 2 / 5
\end{array}\right)
$$

Selanjutnya jika tabel matriks transisi diselesaikan maka didapatkan matriks transisi perpindahan merek sepeda motor matik sebagai berikut:
$T=\left(\begin{array}{ccccc}0.45 & 0.23 & 0.09 & 0.14 & 0.09 \\ 0.08 & 0.80 & 0.04 & 0.08 & 0 \\ 0.11 & 0.16 & 0.63 & 0.05 & 0.05 \\ 0.12 & 0.23 & 0.41 & 0.12 & 0.12 \\ 0 & 0.2 & 0.2 & 0.2 & 0.40\end{array}\right)$

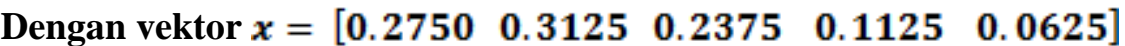

Adapun seluruh pengolahan data dalam penelitian ini menggunakan piranti lunak PTC Windchill Quality Solutions 10.2.dan dengan menggunakan piranti lunak tersebut kondisi matriks transisi Markov dan vektor state dapat ditunjukkan seperti pada gamabar berikut

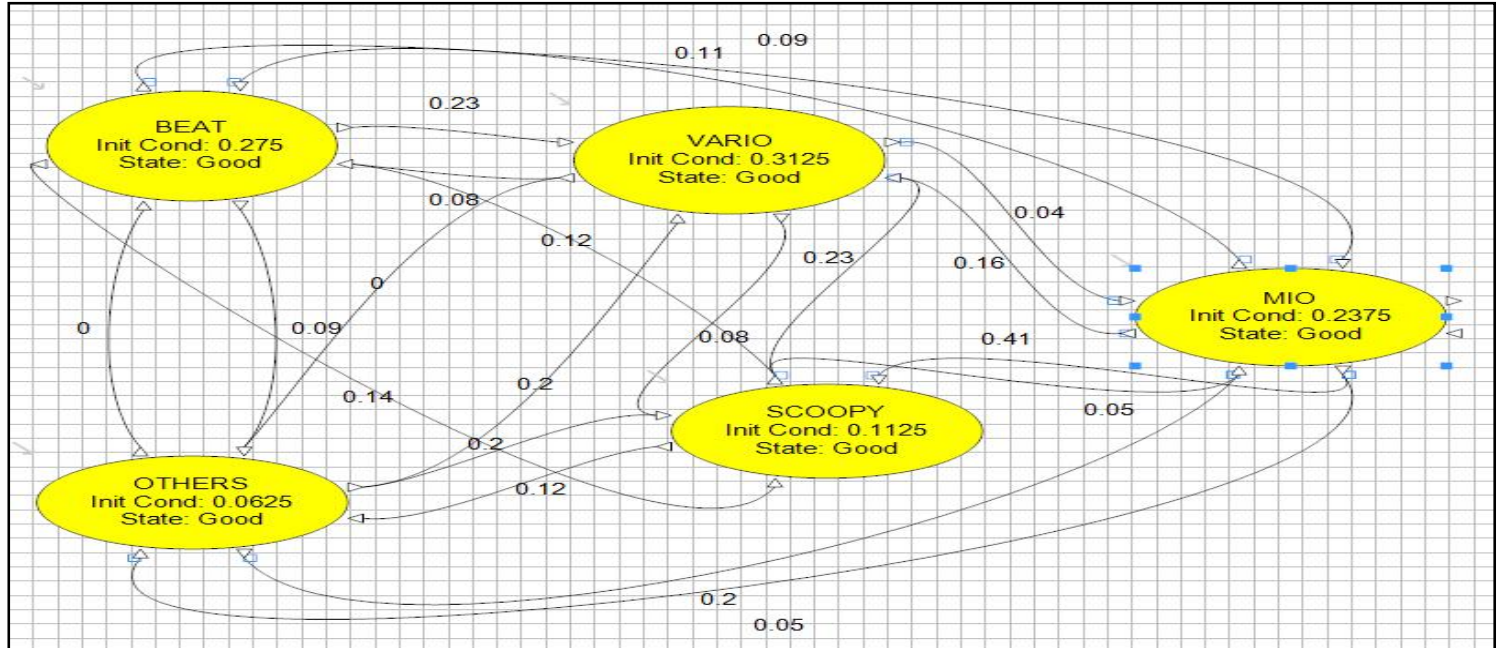

Diolah dengan PTC Windchill Quality Solutions v 10.2 


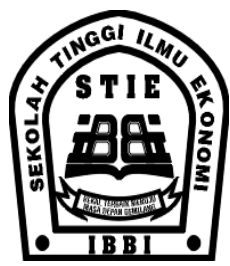

ISSN 1858-3199

JURNAL

MANAJEMEN BISNIS

STIE IBBI

\section{Hasil Prediksi Pangsa Pasar Model Perpindahan Merek Sepeda Motor Matik}

Hasil prediksi atau peramalan terhadap pangsa pasar sepada motor matik khususnya untuk mahasiswa STIE IBBI menunjukkan ramalan pada saat kondisi steady state dimasa yang akan datang, pangsa pasar Honda Vario akan mengalami peningkatan paling signifikan sekitar 18 persen dari pangsa pasar awal sebesar 31,25 persen menjadi 49,15 persen dengan rata-rata selama $n$-step menuju kondisi steadyu state sebesar 45,06 persen. Sedangkan seluruh jenis dan merek sepeda motor lainnya diprediksi akan mengalami penurunan atau relatif stagnan. Penurunan pangsa pasar yang paling signifikan dialami oleh Honda Beat sekitar persen ke kondisi pangsa pasar dimasa depan menjadi 13,63 persen, Honda Scoopy mengalami penurunan sekitar 2 persen dari kondis pangsa pasar awal sebesar 11,25 persen menjadi 9,22 persen. Sedangkan pangsa pasar Yamaha Mio diprediksi akan relatif stabil dikisaran 22-23 persen, demikian juga pangsa pasar merek-merek lain dikisaran 6 persen. Kondisi ini dapat dilihat dari tabel 4berikut yang merupakan hasil pengolahan data matriks transisi Markov dan vektor state.

Tabel 4. Hasil Peramalan Pangsa Pasar

\begin{tabular}{|c|c|c|c|}
\hline $\begin{array}{c}\text { State } \\
\text { Identifier }\end{array}$ & State & $\begin{array}{c}\text { State } \\
\text { Probability }\end{array}$ & $\begin{array}{l}\text { Mean State } \\
\text { Probability }\end{array}$ \\
\hline BEAT & Good & 0.136312 & 0.158646 \\
\hline VARIO & Good & 0.491578 & 0.450641 \\
\hline MIO & Good & 0.222014 & 0.231758 \\
\hline SCOOPY & Good & 0.092206 & 0.096028 \\
\hline OTHERS & Good & 0.057891 & 0.062928 \\
\hline
\end{tabular}

\section{KESIMPULAN}

Prediksi atau ramalan perubahan posisi pangsa pasar sepeda motor matik dikalangan mahasiswa STIE IBBI Medan yang diakibatkan oleh perpindahan merek menyebabkan sepeda motor jenis Honda Vario akan mendominasi pangsa pasar, sedangkan merek dan jenis lainnya akan relatif turun dan stagnan. Kondisi ini dapat dijelaskan dengan melihat besaran probabilitas state untuk konsumen yang tidak akan melakukan perpindahan merek atau konsumen dengan loyalitas merek yakni sebesar 0,80 jauh lebih besar dengan yang dimiliki merek dan jenis lainnya.

\section{DAFTAR PUSTAKA}

Awogbemi, Clement Adeyeye, Oloda, Festus Smart and Osama, Caleb. 2012. Kehinde Modeling Brand Switching in Consumers' Products Journal of Economics and Sustainable Development www.iiste.org ISSN 2222-1700 (Paper) ISSN 2222-2855 (Online) Vol.3, No.12, 2012

Chaarlas, I.J and Rajkumar, R. 2012, "Brand Switching - A conceptual Analysis", THAVANIJRMM, Vol.1(2) pp 1-5.

Datong, G. Monday, 2011. A Markov Chain Model Analysis of GSM Network Service Providers Marketing Mix International Journal of Engineering \& Technology IJET-IJENS Vol: 11 No: 04 113804-7676 IJET-IJENS August 2011 
Djan, I. dan Ruvendi, R. 2006. Prediksi Perpindahan Penggunaan Merek Handphone di Kalangan Mahasiswa (Studi Kasus Pada Mahasiswa STIE Binaniaga). Jurnal Ilmiah Binaniaga 2(1).

Hasdianti, R. 2006. MA-4173 Kapita Selekta Matematika Terapan I (Teori Antrian). Penerbit ITB, Bandung.

Hatidja, Djoni. Abdullah, Sri H. dan Salaki Deiby T. 2013 Pergeseran Pangsa Pasar Kartu Seluler Pra Bayar Gsm Menggunakan Analisis Rantai Markov (Studi Kasus: Mahasiswa Fmipa Unsrat Manado) PROSIDING Seminar Nasional Matematika dan Pendidikan Matematika tanggal 9 November 2013 di Jurusan Pendidikan Matematika FMIPA UNY ISBN:978$979-16353-9-4$

Howard, A., and Rorres, C. 2004. Aljabar Linear Elementer versi Aplikasi. Edisi ke-8, jilid 2. Terjemahan Izham Harmein dan Julian Gresdando. Erlangga, Jakarta.

OSENI, B. Azeez and Femi J. 2013. On The Use Of Markov Analysis In Marketing of Telecommunication Product In Nigeria. Ayoola International Journal of Mathematics and Statistics StudiesVol.1 No. 1, March 2013, pp. 63-68 Published by European Centre for Research, Training and Development, UK (www.ea-journals.org)

Papoulis, Athanasius, 1992. Probabilitas, Variabel Random, dan Proses Stokastik, edisi ke-2, Gadjah Mada university Press, Yogyakarta, 1992.

Umeshanand, G. 2008. Study on Brand Switching in Consumer Products, MBA Thesis, Department of Management and Technology Chhattisgarh Vivekananda Technical University India 


\title{
PENGARUH LINGKUNGAN KERJA DAN STRESS KERJA TERHADAP PRESTASI KERJA KARYAWAN PADA PT INDAH MEGAH JAYA VULKANISIR MEDAN
}

\author{
Hendri Sembiring \\ Dosen Tetap STIE IBBI Medan \\ Tetty Sigalingging \\ Program Studi Manajemen STIE IBBI Medan
}

\begin{abstract}
ABSTRAK/Abstract
Lingkungan kerja yang baik akan memberikan pengaruh yang positif terhadappeningkatan prestasi kerja karyawan. Selain faktor lingkungan kerja, tuntutan yang tidak mampu dikendalikan oleh karyawan akan menimbulkan ketegangan dalam diri karyawan danjika tidak dapat diatasi maka karyawan tersebut akan mengalami stres. Dalam porsi tertentu,stres akan berpengaruh positif, mendorong, merangsang dan menantang manusia untuk selalu aktif dan produktif. Tujuan yang akan dicapai dalam penelitian ini adalah untuk mengetahui pengaruh lingkungan kerja dan stres kerja terhadap prestasi kerja karyawan pada PT Indah Megah Jaya Vulkanisir Medan. Metode analisis yang digunakan adalah regresi linier berganda, pengujian hipotesis menggunakan uji $\mathrm{F}$ (simultan) dan uji t (parsial), serta ujikoefisien determinasi. Populasi dalam penelitian ini adalah seluruh karyawan pada PT Indah Megah Jaya Vulkanisir Medan yang berjumlah 275 orang. Penentuan sampel dalam penelitian ini menggunakan rumus Slovin dengan menggunakan taraf kepercayaan 90 persen dan jumlah sampel sebanyak 73 orang karyawan. Hasil analisis regresi linier menunjukkan persamaan pengaruh lingkungan kerja dan stres kerja terhadap prestasi kerja karyawan pada PT Indah Megah Jaya Vulkanisir Medan adalah $\mathrm{Y}=3,780+0,745$ X1 + 0,131 X2. Hasil penelitian uji hipotesis dengan uji $\mathrm{F}$ menunjukkan bahwa variabel lingkungan kerja dan stress kerja secara simultan berpengaruh terhadap prestasi kerja karyawan pada PT Indah Megah Jaya Vulkanisir Medan dan uji t menunjukkan bahwa variabel lingkungan kerja secara parsial berpengaruh terhadap prestasi kerja karyawan sedangkan variabel stres kerja tidak berpengaruh terhadap prestasi kerja karyawan pada PT Indah Megah Jaya Vulkanisir Medan.
\end{abstract}

Kata Kunci : lingkungan kerja, stres kerja dan prestasi kerja.

Good working environment will provide a positive influence on employee performance improvement. In addition to the work environment, demands that can not be controlled by the employee will lead to tensions within the employee and if the employee can not be resolved then it will experience stress. In certain portions, the stress will be a positive influence, encouraging, stimulating and challenging people to always be active and productive. The objective in this research was to determine the effect of working environment and job stress on employee performance at PT Indah Megah Jaya Vulkanisir Medan. The analytical method used was multiple linear regression, hypothesis testing used the Ftest (simultaneous) and ttest (partial), and the coefficient of determination test. The population in this research were all employees at PT Indah Megah Jaya Vulkanisir Medan which totalling 275 people. The samples in this research used Slovin formula with a 90 percent confidence level and a sample of 73 employees. The results of linear regression analysis showed similarities influence of work environment and job stress on employee performance at PT Indah Megah Jaya Vulkanisir Medan at $Y=3,780+0,745$ X1 + 0,131 X2. The results of hypothesis test with Ftest showed that the work environment variables and job stress simultaneously affect employee's work performance at PT Indah Megah Jaya Vulkanisir Medan and ttest showed that the working environment variable partially has an effect on employee 

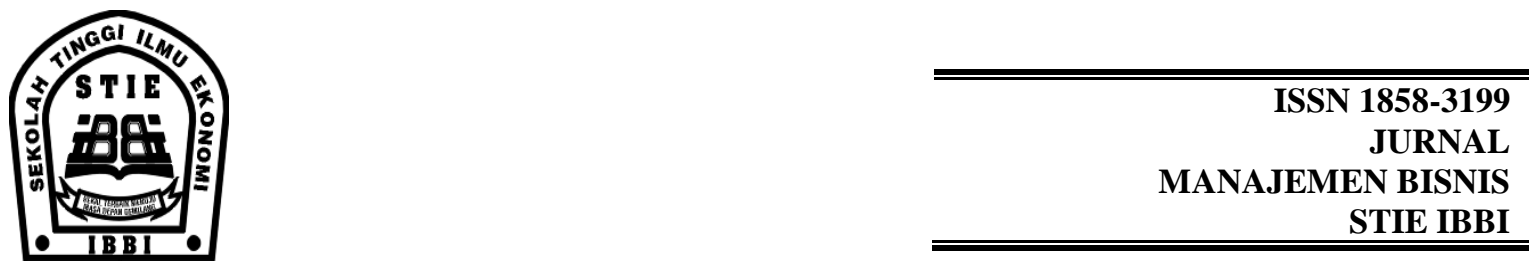

performance while work stress variables has no effect on employee performance at PT Indah Megah Jaya Vulkanisir Medan.

Key Words : work environment, job stress and job performance

\section{PENDAHULUAN}

Sumber daya manusia adalah salah satu sumber daya yang sangat dibutuhkan oleh perusahaan, karena berperan aktif terhadap jalannya perusahaan dan proses pengambilan keputusan serta merupakan satu-satunya sumber daya yang memiliki akal perasaan, keinginan, keterampilan, pengetahuan, dorongan, daya dan karya (rasio, rasa dan karsa). Oleh karena itu, perusahaan harus memberikan perhatian secara maksimal kepada sumber daya manusia yang dimilikinya, baik dar segi kualitas, kemampuan, pengetahuan dan keterampilannya sehingga sumber daya manusia memiliki dorongan untuk memberikan segala kemampuannya sesuai dengan yang diharapkan perusahaan dalam upaya pencapaian tujuan perusahaan secara maksimal. Pada umumnya, prestasi kerja dipengaruhi oleh banyak faktor, baik faktor yang berasal dari dalam diri karyawan maupun faktor yang berasal dari lingkungannya. Salah satu faktor lingkungan yang mempengaruhi prestasi kerja karyawan adalah lingkungan kerja dimana karyawan melaksanakan aktivitas kerjanya. Lingkungan kerja yang baik akan memberikan pengaruh yang positif terhadap peningkatan prestasi kerja karyawan, begitu juga sebaliknya. Lingkungan kerja yang baik adalah tempat bekerja yang mendapat cahaya yang cukup, bebas dari kebisingan dan gangguan, fasilitas dan alat bantu pekerjaan yang memadai serta hubungan kerja yang baik antara orang-orang yang ada di tempat kerja. Lingkungan kerja yang baik akan memberikan dampak tersendiri bagi sumber daya manusia di dalamnya, yaitu sumber daya manusia dapat melaksanakan kegiatan secara optimal, sehat, aman dan nyaman serta memberikan dorongan bagi para karyawan untuk melakukan pekerjaan dengan baik. Selain faktor lingkungan kerja, seseorang dapat dikatakan memiliki prestasi dalam bekerja, jika beban kerja yang ditetapkan tercapai atau realisasi hasil lebih tinggi daripada yang ditetapkan perusahaan. Akan tetapi, tuntutan yang tidak mampu dikendalikan oleh karyawan akan menimbulkan ketegangan dalam diri karyawan dan jika tidak dapat diatasi maka karyawan tersebut akan mengalami stres. Dalam porsi tertentu, stres akan bersifat konstruktif dan akan berpengaruh positif, mendorong, merangsang dan menantang manusia untuk selalu aktif dan produktif. Tetapi stres yang terlalu berlebihan akan berefek negatif, seperti ketidakharmonisan, rasa ogah-ogahan, produktivitas yang rendah dan prestasi kerja yang menurun. Perusahaan harus dapat memperhatikan kondisi yang ada dalam perusahaan baik di dalam maupun di luar ruangan tempat kerja sehingga karyawan dapat bekerja dengan lancar dan merasa tenang. Ketenangan karyawan di dalam menjalankan aktivitasnya merupakan suatu kondisi positif dalam pekerjaan yang dapat mendukung terciptanya prestasi kerja yang tinggi sehingga pelaksanaan kegiatan di dalam perusahaan dapat berjalan dengan baik. PT Indah Megah Jaya Vulkanisir adalah salah satu perusahaan swasta yang bergerak dalam bidang vulkanisir. Sebagai salah satu perusahaan yang berorientasi terhadap laba, perusahaanmembutuhkan sumber daya manusia yang memiliki prestasi kerja yang tinggi untuk menghasilkan produk yang berkualitas dan memiliki daya saing dengan perusahaan lain. Pengamatan pada PT Indah Megah Jaya Vulkanisir menunjukkan lingkungan kerja yang ada pada perusahaan saat ini masih kurang memadai, seperti ruang kerja yang relatif sempit dan suhu udara yang cenderung panas yang disebabkan oleh kurang luasnya gudang penyimpanan produk dan masih ada beberapa ruang kerja yang belum dilengkapi dengan pendingin ruangan serta adanya hubungan yang kurang harmonis antara pimpinan dengan bawahan yang disebabkan pengawasan pimpinan yang ketat terhadap hasil kerja karyawan. Sedangkan permasalahan stres yang dihadapi 


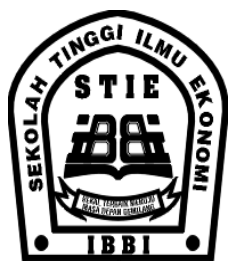

ISSN 1858-3199

JURNAL

MANAJEMEN BISNIS

STIE IBBI

karyawan di dalam perusahaan disebabkan oleh adanya tekanan dan bermacam-macam pekerjaan yang diberikan oleh pimpinan serta harus diselesaikan dalam waktu yang relatif singkat sehingga mengakibatkan karyawan cenderung tidak mengetahui apa yang harus dilakukan untuk menyelesaikan pekerjaan tersebut dan menimbulkan stres pada diri karyawan. Meskipun lingkungan kerja dan stres kerja tidak melaksanakan aktivitas dalam suatu perusahaan, namun lingkungan kerja dan stres kerja mempunyai pengaruh langsung terhadap para karyawan yang melaksanakan aktivitas. Oleh karena lingkungan kerja dan stres kerja menjadi bagian yang penting dalam manajemen sumber daya manusia, yakni sebagai faktor yang penting dalam meningkatkan prestasi kerja karyawan, maka peneliti tertarik untuk mengadakan penelitian dengan judul penelitian : "Analisis Pengaruh Lingkungan Kerja dan Stres Kerja terhadap Prestasi Kerja Karyawan Pada PT Indah Megah Jaya Vulkanisir Medan”.

Rumusan Masalah

Berdasarkan latar belakang di atas, maka permasalahan yang ada dapat dirumuskan sebagai berikut : 1"Bagaimana pengaruh lingkungan kerja dan terhadap prestasi kerja karyawan pada PT Indah Megah Jaya Vulkanisir Medan?

2 "Bagaimana pengaruh stress kerja terhadap prestasi kerja karyawan pada PT Indah Megah Jaya Vulkanisir Medan?

3"Bagaimana pengaruh lingkungan kerja dan stress kerja terhadap prestasi kerja karyawan pada PT Indah Megah Jaya Vulkanisir Medan?

Tujuan Penelitian

Tujuan yang ingin dicapai dalam penelitian ini adalah :

1 "Untuk mengetahui pengaruh lingkungan kerja terhadap prestasi kerja karyawan pada PT Indah Megah Jaya Vulkanisir Medan."

2 "Untuk mengetahui pengaruh stress kerja terhadap prestasi kerja karyawan pada PT Indah Megah Jaya Vulkanisir Medan"

3 "Untuk mengetahui pengaruh lingkungan kerja dan stress kerja terhadap prestasi kerja karyawan pada PT Indah Megah Jaya Vulkanisir Medan"

\section{TINJAUAN LITERATUR}

\section{Lingkungan Kerja}

Lingkungan kerja yang baik akan memberikan kenyamanan pribadi maupun di dalam membangkitkan semangat kerja karyawan sehingga dapat mengerjakan tugas-tugas dengan baik. Selain itu, karyawan akan lebih senang dan nyaman dalam bekerja apabila fasilitas yang ada dalam keadaan bersih, tidak bising, pertukaran udara yang cukup baik dan peralatan yang memadai serta relatif modern. Cikmat dalam Nawawi (2003:292) mengemukakan bahwa, "Lingkungan kerja adalah serangkaian sifat kondisi kerja yang dapat diukur berdasarkan persepsi bersama dari para anggota organisasi yang hidup dan bekerjasama dalam suatu organisasi”. Menurut Indriyo (2008:151), "Lingkungan kerja adalah segala sesuatu yang ada di sekitar pekerja yang dapat mempengaruhi pekerja dalam bekerja, meliputi pengaturan penerangan, pengontrolan suara gaduh, pengaturan kebersihan tempat kerja dan pengaturan keamanan tempat kerja”. Definisi lain menurut Sedarmayanti (2001:21), "Lingkungan kerja adalah keseluruhan alat perkakas dan bahan yang dihadapi, lingkungan sekitarnya dimana seseorang bekerja, metode kerjanya serta pengaturan kerjanya, baik sebagai perseorangan maupun sebagai kelompok". Selanjutnya, Nitisemito (2002:25) mengemukakan bahwa, "Lingkungan kerja adalah segala sesuatu yang ada di sekitar para pekerja dan dapat mempengaruhi dirinya dalam menjalankan tugas yang dibebankan". 


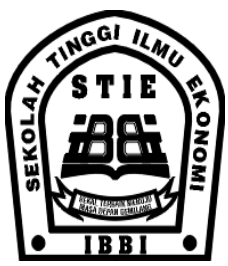

ISSN 1858-3199

JURNAL

MANAJEMEN BISNIS

STIE IBBI

Manusia akan mampu melaksanakan kegiatannya dengan baik sehingga dicapai suatu hasil yang optimal apabila ditunjang oleh kondisi lingkungan yang sesuai. Suatu kondisi lingkungan dikatakan baik atau sesuai apabila manusia dapat melaksanakan kegiatannya secara optimal, sehat, aman dan nyaman. Ketidaksesuaian lingkungan kerja dapat dilihat akibatnya dalam jangka waktu yang lama. Lebih jauh lagi, lingkungan kerja yang kurang baik dapat menuntut tenaga dan waktu yang lebih banyak dan tidak mendukung diperolehnya rancangan sistem kerja yang efisien. Banyak faktor yang mempengaruhi terbentuknya suatu kondisi lingkungan kerja. Menurut Sedarmayanti (2009:28-35), ada beberapa faktor yang mempengaruhi terbentuknya suatu kondisi lingkungan kerja yang dikaitkan dengan kemampuan karyawan, yaitu :

1. Penerangan/cahaya di tempat kerja

Cahaya atau penerangan sangat besar manfaatnya bagi karyawan untuk mendapatkan keselamatan dan kelancaran kerja. Oleh sebab itu, adanya penerangan (cahaya) yang terang tetapi tidak menyilaukan perlu diperhatikan perusahaan. Cahaya yang kurang jelas (kurang cukup) mengakibatkan penglihatan menjadi kurang jelas, sehingga pekerjaan akan lambat, banyak mengalami kesalahan dan pada akhirnya menyebabkan kurang efisien dalam melaksanakan pekerjaan sehingga tujuan organisasi sulit dicapai. Pada dasarnya, cahaya dapat dibedakan menjadi dua, yaitu :

a. Cahaya alam yang berasal dari sinar matahari.

b. Cahaya buatan berupa lampu, meliputi cahaya langsung, cahaya setengah langsung, cahaya tidak langsung dan cahaya setengah tidak langsung.

2. Temperatur/suhu udara di tempat kerja

Temperatur yang terlalu dingin akan mengakibatkan gairah kerja karyawan menurun, sedangkan temperatur yang terlalu panas akan mengakibatkan cepat timbulnya kelelahan tubuh dan dalam bekerja cenderung membuat banyak kesalahan.

3. Kelembaban di tempat kerja

Kelembaban adalah banyaknya air yang terkandung dalam udara, yang biasanya berhubungan atau dipengaruhi oleh temperatur udara dan secara bersama-sama antara temperatur, kelembaban, kecepatan udara bergerak dan radiasi panas dari udara akan mempengaruhi keadaan tubuh manusia pada saat menerima atau melepaskan panas dari tubuhnya.

4. Sirkulasi udara di tempat kerja

Udara di sekitar tempat kerja dikatakan kotor apabila kadar oksigen dalam udara tersebut telah berkurang dan bercampur dengan gas atau bau-bauan yang berbahaya bagi kesehatan tubuh. Udara yang kotor di tempat kerja tidak boleh dibiarkan berlangsung terlalu lama, karena akan mempengaruhi kesehatan tubuh dan mempercepat proses kelelahan. Sebaliknya, dengan cukupnya oksigen di sekitar tempat kerja, ditambah dengan adanya tanaman di sekitar tempat kerja, akan memberikan kesejukan dan kesegaran selama bekerja, yang akan membantu mempercepat pemulihan tubuh akibat lelah setelah bekerja.

5. Kebisingan di tempat kerja

Kebisingan adalah bunyi yang tidak dikehendaki oleh telinga, karena terutama dalam jangka panjang bunyi tersebut dapat mengganggu ketenangan bekerja, merusak pendengaran dan menimbulkan kesalahan komunikasi, bahkan bisa menyebabkan kematian.

6. Getaran mekanis di tempat kerja

Getaran mekanis adalah getaran yang ditimbulkan oleh alat mekanis, yang sebagian dari getaran ini sampai ke tubuh karyawan dan dapat menimbulkan akibat yang tidak diinginkan. Secara umum, getaran mekanik dapat mengganggu tubuh dalam hal : 


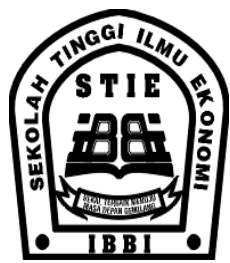

ISSN 1858-3199

JURNAL

MANAJEMEN BISNIS

STIE IBBI

a. Konsentrasi bekerja.

b. Datangnya kelelahan.

c. Timbulnya beberapa penyakit karena gangguan terhadap mata, syaraf, peredaran darah, otot,tulang, dsbnya.

7. Bau tidak sedap di tempat kerja

Adanya bau-bauan di sekitar tempat kerja dapat dianggap sebagai pencemaran, karena dapat mengganggu konsentrasi bekerja dan mempengaruhi kepekaan penciuman.

8. Tata warna di tempat kerja

Menata warna di tempat kerja perlu dipelajari dan direncanakan dengan sebaik-baiknya. Pada kenyataannya, warna mempunyai pengaruh besar terhadap perasaan. Sifat dan pengaruh warna kadang-kadang menimbulkan rasa senang, sedih, dll, karena sifat warna dapat merangsangperasaan manusia.

9. Dekorasi di tempat kerja

Dekorasi mempunyai hubungan dengan tata warna yang baik, karena itu dekorasi tidak hanya berkaitan dengan hiasan ruang kerja tetapi berkaitan juga dengan cara mengatur tata letak, tata warna dan perlengkapan lain untuk bekerja.

10. Musik di tempat kerja

Musik yang nadanya lembut sesuai dengan suasana, waktu dan tempat dapat membangkitkan dan merangsang karyawan untuk bekerja. Oleh karena itu, lagu perlu dipilih dengan selektif, karena tidak sesuainya musik yang diperdengarkan di tempat kerja akan mengganggukonsentrasi kerja.

11. Keamanan di tempat kerja

Untuk menjaga tempat dan kondisi lingkungan kerja tetap dalam keadaan aman, maka perlu diperhatikan adanya keamanan dalam bekerja. Baik buruknya lingkungan kerja harus diukur dengan menggunakan suatu indicator penilaian. Berdasarkan faktor-faktor yang dikemukakan Sedarmayanti (2009:28-35), maka indicator yang akan digunakan untuk mengukur lingkungan kerja dalam penelitian ini terdiri dari :

1. Penerangan

2. Temperatur

3. Sirkulasi udara

4. Kebisingan

5. Tata warna

6. Keamanan di tempat kerja

\section{Stress Kerja}

Stres merupakan situasi yang mungkin dialami karyawan di dalam sebuah organisasi/perusahaan. Stres menjadi masalah yang penting karena stres dapat mempengaruhi kepuasan kerja, prestasi kerja, produktivitas kerja dan kinerja perusahaan secara keseluruhan. Fathoni (2006:130) mengemukakan bahwa, "Stres adalah suatu kondisi ketegangan yang mempengaruhi emosi, proses berpikir dan kondisi seseorang". Menurut Mikhail dalam Ardana, et.al. (2009:25), "Stres adalah suatu keadaan yang timbul dari kapasitas tuntutan yang tidak seimbang, baik nyata maupun dirasakan dalam tindakan penyesuaian organ". Definisi lain menurut Szilagyi dalam Ardana, et.al. (2009:24), "Stres adalah pemahaman yang bersifat internal yang menciptakan adanya ketidakseimbangan fisik dan psikis dalam diri seseorang sebagai akibat lingkungan eksternal organisasi lain". Selanjutnya Hunt, et.al. dalam Hariandja (2009:303) mengemukakan bahwa, "Stres adalah situasi ketegangan/tekanan emosional yang dialami seseorang 


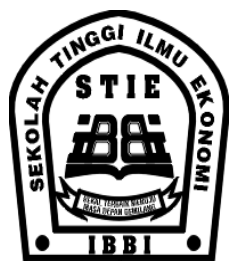

ISSN 1858-3199

JURNAL

MANAJEMEN BISNIS

STIE IBBI

yang sedang menghadapi tuntutan yang sangat besar, hambatan-hambatan dan adanya kesempatan yang sangat penting yang dapat mempengaruhi emosi, pikiran dan kondisi fisik seseorang". Pada dasarnya, stres bisa bersumber dari pekerjaan dan lingkungan kerja serta dari luar pekerjaan. Hasibuan (2008:204) mengemukakan bahwa sumber stres karyawan antara lain sebagai berikut :

1. Beban kerja yang sulit dan berlebihan.

2. Tekanan dan sikap pimpinan yang kurang adil dan wajar.

3. Waktu dan peralatan kerja yang kurang memadai.

4. Konflik antar pribadi dengan pimpinan atau kelompok kerja.

5. Balas jasa yang terlalu rendah.

6. Masalah-masalah keluarga, seperti anak, istri, mertua dan lain-lain.

Sedangkan menurut Ardana, et.al. (2009:25), sumber stres terdiri dari :

1. Faktor-faktor yang melekat pada pekerjaan.

2. Peranan dalam organisasi.

3. Hubungan dalam organisasi.

4. Perkembangan karier.

5. Struktur dan iklim organisasi.

6. Hubungan organisasi dengan pihak luar.

7. Faktor dari dalam individu yang bersangkutan.

8. Kepemimpinan.

Untuk mengukur stres kerja, diperlukan suatu indikator pengukuran. Berdasarkan sumber stres yang dikemukakan Hasibuan (2008:204) di atas, maka indikator yang akan digunakan untuk mengukur stres kerja dalam penelitian ini ditetapkan sebagai berikut :

1. Beban kerja adalah keadaan dimana karyawan tidak mengerti dengan jelas pekerjaan yang merupakan tugas dan tanggung jawabnya.

2. Sikap pimpinan adalah keadaan dimana tidak adanya dukungan dari pimpinan terhadap pelaksanaan tugas.

3. Peralatan kerja adalah keadaan dimana sarana dan prasarana kerja yang tersedia di dalam perusahaan kurang memadai.

4. Konflik adalah keadaan dimana adanya konflik di dalam pelaksanaan tugas.

5. Balas jasa adalah keadaan dimana tidak adanya keseimbangan balas jasa yang diterima dengan hasil kerja yang diberikan.

\section{Prestasi Kerja}

Prestasi kerja karyawan merupakan faktor penting bagi kesuksesan perusahaan. Hal ini disebabkan oleh peran karyawan sebagai salah satu faktor produksi penting pada pelaksanaan setiap aktivitas di dalam perusahaan. Bernardin dan Russel dalam Sutrisno (2010:150) mengemukakan bahwa, "Prestasi didefinisikan sebagai catatan tentang hasil-hasil yang diperoleh dari fungsi-fungsi pekerjaan tertentu atau kegiatan tertentu selama kurun waktu tertentu". Menurut As'ad dalam Sutrisno (2010:150), "Prestasi kerja adalah tingkat sejauh mana keberhasilan seseorang di dalam melakukan tugas pekerjaannya". Definisi lain menurut Heidjrachman dan Husnan dalam Sunyoto (2012:18), "Prestasi kerja adalah sesuatu hasil kerja yang dicapai seseorang dalam menyelesaikan pekerjaan yang dibebankan kepadanya". Selanjutnya Hasibuan (2008:94) mengemukakan bahwa, "Prestasi kerja adalah hasil kerja yang dicapai seseorang dalam melaksanakan tugas-tugas yang dibebankan kepadanya yang didasarkan atas kecakapan, pengalaman dan kesungguhan serta waktu". 


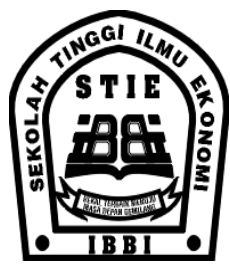

ISSN 1858-3199

JURNAL

MANAJEMEN BISNIS

STIE IBBI

Menurut Steers dalam Sutrisno (2010:151), umumnya orang percaya bahwa prestasi kerja individu merupakan fungsi gabungan dari tiga faktor, yaitu :

1. Kemampuan, perangai dan minat seorang pekerja.

2. Kejelasan dan penerimaan atas penjelasan peranan seorang pekerja.

3. Tingkat motivasi kerja.

Walaupun setiap faktor di atas mempunyai arti yang penting, tetapi kombinasi ketiga faktor sangat menentukan tingkat hasil setiap pekerja yang akan membantu prestasi organisasi secara keseluruhan. Sementara, menurut Byar dan Rue dalam Sutrisno (2010:151), ada dua faktor yang mempengaruhi prestasi kerja, yaitu :

1. Faktor individu, meliputi :

a. Usaha (Effort), yaitu sejumlah sinergi fisik dan mental yang digunakan dalam menyelenggarakan gerakan tugas.

b. Abilities, yaitu sifat-sifat personal yang diperlukan untuk melaksanakan suatu tugas.

c. Role/Task Perception, yaitu segala perilaku dan aktivitas yang dirasa perlu oleh individu untuk menyelesaikan suatu pekerjaan.

2. Faktor lingkungan

Faktor lingkungan tidak langsung menentukan prestasi kerja seseorang, tetapi mempengaruhifaktor individu, meliputi :

a. Kondisi fisik.

b. Peralatan.

c. Waktu.

d. Material.

e. Pendidikan.

f. Supervisi.

g. Desain organisasi.

h. Pelatihan.

i. Keberuntungan.

Prestasi kerja harus diukur berdasarkan variabel yang berhubungan dengan perilaku individu yang bersangkutan. Untuk mengukur perilaku karyawan atau sejauh mana karyawan berperilaku agar sesuai dengan apa yang diharapkan oleh perusahaan, yaitu prestasi kerja yang dikaitkan dengan pencapaian hasil dari standar kerja yang telah ditetapkan, maka indikator yang digunakan dalam pengukuran prestasi kerja menurut Sutrisno (2010:152-153) terdiri dari :

1. Hasil kerja adalah tingkat kuantitas maupun kualitas yang telah dihasilkan dan sejauh mana pengawasan dilakukan.

2. Pengetahuan pekerjaan adalah tingkat pengetahuan yang terkait dengan tugas pekerjaan yang akan berpengaruh langsung terhadap kuantitas dan kualitas dari hasil kerja.

3. Inisiatif adalah tingkat inisiatif selama melaksanakan tugas pekerjaan khususnya dalam hal penanganan masalah-masalah yang timbul.

4. Kecekatan mental adalah tingkat kemampuan dan kecepatan dalam meneriman instruksi kerja dan menyesuaikan dengan cara kerja serta situasi kerja yang ada.

5. Sikap adalah tingkat semangat kerja serta sikap positif dalam melaksanakan tugas pekerjaan.

6. Disiplin waktu dan absensi adalah tingkat ketepatan waktu dan tingkat kehadiran. 


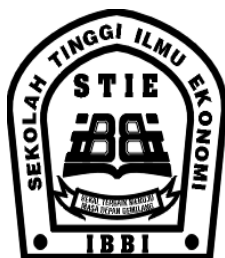

ISSN 1858-3199

JURNAL

MANAJEMEN BISNIS

STIE IBBI

\section{KERANGKA KONSEPTUAL}

Lingkungan kerja adalah lingkungan dimana para pekerja melaksanakan tugas dan pekerjaannya.

Stres adalah suatu kondisi ketegangan yang mempengaruhi emosi, proses berpikir dan kondisi seseorang dimana ia terpaksa memberikan tanggapan melebihi kemampuan penyesuaian dirinya terhadap suatu tuntutan lingkungan.

Prestasi kerja adalah hasil kerja yang telah dicapai seseorang dari tingkah laku kerjanya dalam melaksanakan aktivitas kerja.

Lingkungan kerja yang menyenangkan, seperti adanya hubungan yang baik antara sesame karyawan, hubungan yang baik antara pemimpin dan bawahan, ruang kerja, penerangan, suhu udara, warna serta kebersihan tempat kerja yang baik akan memberikan pengaruh yang positif terhadap peningkatan prestasi kerja karyawan.

Begitu juga dengan stres kerja, dalam hubungannya dengan pekerjaan, stres dapat berpengaruh pada berbagai macam faktor, salah satunya adalah prestasi kerja karyawan. Stres kerja10 dalam tingkat sedang yang dialami karyawan dapat meningkatkan prestasi kerja, tetapi stres yang terlalu tinggi atau terlalu rendah dapat menurunkan prestasi kerja karyawan. Stres kerja yang sangat rendah dapat menyebabkan prestasi kerja yang rendah juga, karena karyawan tidak merasakan adanya tekanan atau tantangan sehingga kemungkinan besar tidak melakukan usaha yang tinggi untuk menghadapinya. Sebaliknya, stres yang meningkat memberi arti bahwa seseorang mengalami banyak tuntutan dalam pekerjaannya sehingga tingkat usaha akan ditingkatkan yang akan dapat meningkatkan prestasi kerja sampai titik tertentu di mana seseorang masih mampu mengatasinya.Tetapi, ketika stres melebihi tingkat yang dapat dikendalikan maka prestasi kerja akan menurun. Kerangka konseptual yang berfungsi sebagai penuntun alur berpikir dan dasar penelitian yang dapat dilihat pada Gambar 1 berikut :

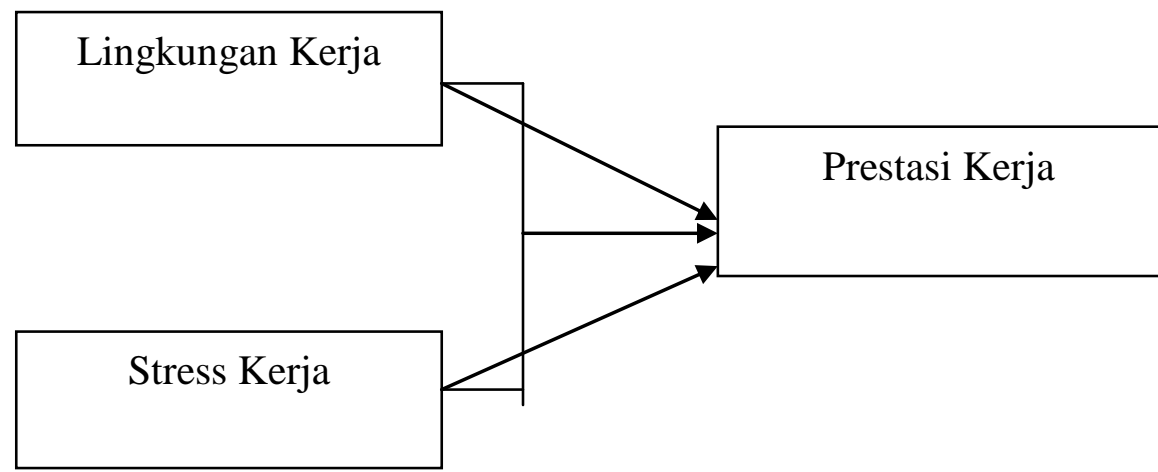

Gambar 1 Kerangka Konseptual

Berdasarkan latar belakang, rumusan masalah dan kerangka konseptual di atas, maka hipotesis dalam penelitian ini adalah :

H0 : Lingkungan kerja dan stres kerja secara parsial maupun simultan tidak berpengaruh terhadap prestasi kerja karyawan pada PT Indah Megah Jaya Vulkanisir Medan.

Hi : Lingkungan kerja dan stres kerja secara parsial maupun simultan berpengaruh terhadap prestasi kerja karyawan pada PT Indah Megah Jaya Vulkanisir Medan. 


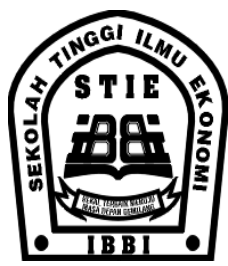

ISSN 1858-3199

JURNAL

MANAJEMEN BISNIS

STIE IBBI

\section{METODE PENELITIAN}

Penelitian dilaksanakan pada PT Indah Megah Jaya Vulkanisir Medan yang terletak di Jalan Medan Tanjung Morawa Km. 22,5 Medan. Waktu penelitian direncanakan terhitung dari bulan Februari 2013 sampai dengan bulan Mei 2013. Populasi dalam penelitian ini adalah seluruh karyawan pada PT Indah Megah Jaya Vulkanisir Medan yang berjumlah 275 orang. Penentuan sampel dalam penelitian ini menggunakan rumus Slovin dengan menggunakan taraf kepercayaan 90 persen. Jadi, jumlah sampel yang diambil dalam penelitian ini adalah 73 orang karyawan PT Indah Megah Jaya Vulkanisir Medan. Metode pengumpulan data dilakukan dengan wawancara, daftar pertanyaan dan studi dokumentasi. Metode analisis yang digunakan adalah regresi linier berganda. Dan uji $\mathrm{F}$ dan uji t dengan pengolahan data menggunakan SPSS.

\section{PEMBAHASAN}

Hasil analisis regresi linier menunjukkan bahwa persamaan pengaruh lingkungan kerja dan stres kerja terhadap prestasi kerja karyawan pada PT Indah Megah Jaya Vulkanisir Medan adalah :

$\mathrm{Y}=\mathrm{a}+\mathrm{b} 1 \mathrm{X} 1+\mathrm{b} 2 \mathrm{X} 2$

$\mathrm{Y}=3,780+0,745 \mathrm{X} 1+0,131 \mathrm{X} 2$

Interpretasinya berarti :

a. Nilai konstanta a yang diperoleh adalah sebesar 3,780, artinya jika variabel lingkungan kerja dan stres kerja dianggap konstan maka prestasi kerja karyawan pada PT Indah Megah Jaya Vulkanisir Medan adalah sebesar 3,780.

b. Nilai koefisien b1 yang diperoleh adalah sebesar 0,745 , artinya jika terjadi peningkatan setiap satu satuan terhadap variabel lingkungan kerja dan variabel stres kerja dianggap konstan maka prestasi kerja karyawan pada PT Indah Megah Jaya Vulkanisir Medan akan mengalami peningkatan sebesar 0,745 .

c. Nilai koefisien b2 yang diperoleh adalah sebesar 0,131 , artinya jika terjadi peningkatan setiap satu satuan terhadap variabel stres kerja dan variabel lingkungan kerja dianggap konstan maka prestasi kerja karyawan pada PT Indah Megah Jaya Vulkanisir Medan akan mengalami peningkatan sebesar 0,131. Nilai koefisien determinasi ditujukan untuk mengetahui seberapa besar kemampuan model dalam menerangkan variabel terikat menunjukkan bahwa nilai Adjusted R Square (koefisien determinasi) yang diperoleh adalah sebesar 0,711 . Hal ini berarti besarnya pengaruh lingkungan 12 kerja dan stres kerja terhadap prestasi kerja karyawan pada PT Indah Megah Jaya Vulkanisir Medan adalah sebesar $71,1 \%$ dan sisanya $28,9 \%$ dipengaruhi oleh faktor-faktor lain, seperti budaya organisasi, motivasi kerja, iklim organisasi serta kompensasi yang berasal dari luar model penelitian ini.

Hasil uji $\mathrm{F}$ yang digunakan untuk menunjukkan apakah variabel bebas yang dimasukkan dalam model mempunyai pengaruh secara simultan terhadap variabel terikat menunjukkan bahwa nilai Fhitung yang diperoleh adalah sebesar 89,624 dengan tingkat signifikansi 0,000. Karena nilai Fhitung yang diperoleh lebih besar dari nilai Ftabel pada derajat kebebasan $(\mathrm{k}-1),(\mathrm{n}-\mathrm{k})=(3-1)$, (73-3) $; \alpha=5 \%(89,624>3,1277)$ dan tingkat signifikansi $\mathrm{F}$ yang diperoleh 0,000 lebih kecil dari 0,05 ( $\operatorname{sig}<0,05$ ), maka hal ini berarti HO ditolak dan Hi diterima artinya variabel lingkungan kerja dan stress kerja secara simultan berpengaruh terhadap prestasi kerja karyawan pada PT Indah Megah Jaya Vulkanisir Medan. 


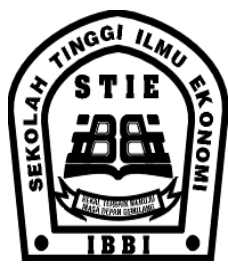

ISSN 1858-3199

JURNAL

MANAJEMEN BISNIS

STIE IBBI

Hasil uji t yang digunakan untuk menunjukkan apakah variabel bebas yang dimasukkan dalam model mempunyai pengaruh secara parsial terhadap variabel terikat menunjukkan bahwa :

a. Nilai thitung yang diperoleh untuk variabel lingkungan kerja adalah sebesar 7,137 dengan tingkat signifikansi 0,000. Karena nilai thitung yang diperoleh lebih besar dari nilai ttabel pada derajat kebebasan $(\mathrm{n}-\mathrm{k})=(73-3) ; \alpha=5 \%(7,137>1,9944)$ dan tingkat signifikansi t yang diperoleh 0,000 lebih kecil dari 0,05 (sig < 0,05), maka hal ini berarti H0 ditolak dan Hi diterima artinya variabel lingkungan kerja secara parsial berpengaruh terhadap prestasi kerja karyawan pada PT Indah Megah Jaya Vulkanisir Medan.

b. Nilai thitung yang diperoleh untuk variabel stres kerja adalah sebesar 1,098 dengan tingkat signifikansi 0,276. Karena nilai thitung yang diperoleh lebih kecil dari nilai ttabel pada derajat kebebasan $(\mathrm{n}-\mathrm{k})=(73-3) ; \alpha=5 \%(1,098<1,9944)$ dan tingkat signifikansi t yang diperoleh 0,276 lebih besar dari 0,05 (sig >0,05), maka hal ini berarti Hi ditolak dan H0 diterima artinya variabel stres kerja secara parsial tidak berpengaruh terhadap prestasi kerja karyawan pada PT Indah Megah Jaya Vulkanisir Medan.

Secara parsial variabel lingkungan kerja berpengaruh lebih dominan daripada variabel stress kerja. Hal ini berarti variabel lingkungan kerja lebih berperan dalam menentukan prestasi kerja karyawan pada PT Indah Megah Jaya Vulkanisir Medan dibandingkan dengan variabel stres kerja.

\section{KESIMPULAN DAN SARAN}

Kesimpulan

Secara simultan, variabel lingkungan kerja dan stres kerja berpengaruh positif dan signifikan terhadap prestasi kerja karyawan pada PT Indah Megah Jaya Vulkanisir Medan. Secara parsial,13 variabel lingkungan kerja berpengaruh lebih dominan dibandingkan dengan variabel stres kerja terhadap prestasi kerja karyawan pada PT Indah Megah Jaya Vulkanisir Medan. Besarnya pengaruh lingkungan kerja dan stres kerja terhadap prestasi kerja karyawan pada PT Indah Megah Jaya Vulkanisir Medan adalah sebesar $71,1 \%$ dan sisanya $28,9 \%$ dipengaruhi oleh faktor-faktor lain, seperti budaya organisasi, motivasi kerja, iklim organisasi serta kompensasi yang berasal dari luar model penelitian ini.

Saran

PT Indah Megah Jaya Vulkanisir Medan seharusnya senantiasa mengusahakan terciptanya lingkungan kerja yang baik melalui penyediaan berbagai sarana dan fasilitas pendukung kerja serta senantiasa memperhatikan hal-hal yang dapat menimbulkan stres kerja bagi karyawan di dalam melaksanakan tugas dan tanggung jawabnya. PT Indah Megah Jaya Vulkanisir Medan seharusnya senantiasa menciptakan lingkungan kerja yang baik di dalam perusahaan, seperti penerangan ruang kerja yang baik, suhu udara yang nyaman, kebersihan yang baik dan ruang kerja yang relatif luas serta selalu berusaha menciptakan hubungan kerja yang baik dan harmonis di antara sesame karyawan. Dalam rangka untuk meningkatkan prestasi kerja karyawan, PT Indah Megah Jaya Vulkanisir Medan diharapkan senantiasa memperhatikan faktor-faktor lain, seperti budaya organisasi yang berlaku di dalam perusahaan, motivasi karyawan di dalam pelaksanaan kerja, iklim organisasi yang ada di dalam perusahaan serta besarnya kompensasi yang diterima karyawan di dalam pekerjaannya sehingga dapat mendorong peningkatan prestasi kerja karyawan. 


\section{DAFTAR PUSTAKA}

Ardana, I Komang, Ni Wayan Mujiati dan Anak Agung Ayu Sriathi. 2009. Perilaku Keorganisasian. Yogyakarta : Graha Ilmu.

Fathoni, Abdurrahmat. 2006. Manajemen Sumber Daya Manusia. Jakarta : PT Rineka Cipta.

Hariandja, Marihot Tua Efendi. 2009. Manajemen Sumber Daya Manusia : Pengadaan, Pengembangan, Pengkompensasian dan Peningkatan Produktivitas Pegawai. Jakarta : PT Gramedia Widiasarana Indonesia.

Hasibuan, Malayu S.P. 2008. Manajemen Sumber Daya Manusia. Jakarta : PT Bumi Aksara. Indriyo, Gitosudarmo. 2008. Manajemen Sumber Daya Manusia. Jakarta : Ghalia Indonesia. Nawawi, Hadari. 2003. Perencanaan SDM untuk Organisasi Profit yang Kompetitif. Yogyakarta : Gadjah Mada University Press.

Nitisemito, Alex. 2002. Manajemen Personalia. Jakarta : Ghalia Indonesia.

Sedarmayanti. 2001. Sumber Daya Manusia dan Produktivitas Kerja. Bandung : CV Mandar Maju. . 2009. Tata Kerja dan Produktivitas Kerja : Suatu Tinjauan Dari Aspek Ergonomi Atau

Kaitan Antara Manusia Dengan Lingkungan Kerjanya. Bandung : CV Mandar Maju.

Sunyoto, Danang. 2012. Teori, Kuesioner dan Analisis Data Sumber Daya Manusia : Praktik Penelitian. Yogyakarta : CAPS.

Sutrisno, Edy. 2010. Manajemen Sumber Daya Manusia. Jakarta : Kencana. 

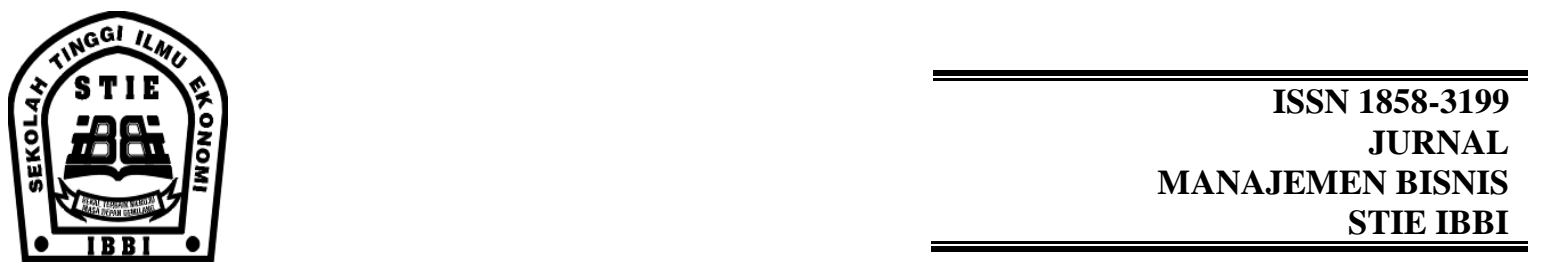